East Asia \& Pacific Region

Sustainable Development Department

\title{
Review and Analysis of the Pollution Impacts from Vietnamese Manufacturing Sectors
}

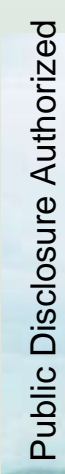


(C) 2008 the International Bank for Reconstruction and Development/The World Bank

$1818 \mathrm{H}$ Street, NW

Washington, DC 20433 USA

March 2008

All rights reserved.

This study was prepared by the Rural Development, Natural Resources and Environment Unit (EASRE) of the East Asia and Pacific Region. The World Bank's Environment and Social Development Strategy for the region provides the conceptual framework for setting priorities, strengthening the policy and institutional frameworks for sustainable development, and addressing key environmental and social development challenges through projects, programs, policy dialogue, non-lending services, and partnerships.

This publication is available online at: http://www.worldbank.org

Suggested citation: Giovanna Dore, Philip Brylski, Jostein Nygard, and Phuong Thi Thanh Tran. 2008. Review and Analysis of the Pollution Impacts from Vietnamese Manufacturing Sectors; EASRE, The World Bank; Washington, D.C.

cover image World Bank Photo Library, Tran Thi Hoa, 2002

cover design by Patricia Hord. Graphik Design

This volume is a product of the staff of the International Bank for Reconstruction and Development/The World Bank. The findings, interpretations, and conclusions expressed in this paper do not necessarily reflect the views of the Executive Directors of the World Bank or the governments they represent. The World Bank does not guarantee the accuracy of the data included in this work. the boundaries, colors, denominations, and other information shown on any map in this work do not imply any judgment on the part of the World Bank concerning the legal status of any territory or the endorsement or acceptance of such boundaries. The material in this publication is copyrighted. Copying and/or transmitting portions or all of this work without permission may be a violation of applicable law. The International Bank for Reconstruction and Development/The World Bank encourages dissemination of its work and will normally grant permission to reproduce portions of the work promptly. For permission to photocopy or reprint any part of this work, please send a request with complete information to the Copyright Clearance Center, inc., 222 Rosewood Drive, Danvers, MA 01923, USA, telephone 978-750-8400, fax 978-750-4470, www.copyright.com. All other queries on rights and licenses, including subsidiary rights, should be addressed to the Office of the Publisher, The World Bank, 1818 H Street NW, Washington, DC 20433, USA, fax 202-522-2422, e-mail pubrights@worldbank.org. 


\section{TABLE OF CONTENIS}

ACKNOWLEDGEMENTS

ACRONYMS

EXECUTIVE SUMMARY Vii

INTRODUCTION

SECTION 1. THE INDUSTRIAL SECTOR IN VIETNAM

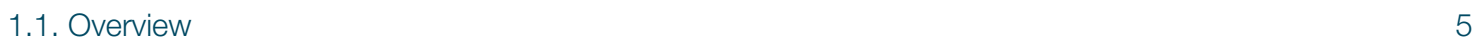

1.2. Ownership Structure and Geographical Distribution 5

1.3. Industrial Estates $\quad 8$

$\begin{array}{lr}\text { 1.4. Handicraft Villages } & 9\end{array}$

1.5. Industrial Sector Expected Growth 10

1.6. Global Integration and the Development of Vietnam's Industrial Sector 12

$\begin{array}{ll}\text { 1.7. Summary } & 15\end{array}$

SECTION 2. REVIEW OF THE POLLUTION STRUCTURE AND IMPACTS 16

2.1. The Industry Pollution Projection System 16

2.2. Pollution Load Indexes 17

$\begin{array}{ll}\text { 2.3. Sector Pollution Profiles } & 21\end{array}$

2.4. Geographic Pollution Profiles $\quad 24$

$\begin{array}{ll}2.5 \text { Summary } & 47\end{array}$

SECTION 3. INSTITUTIONAL AND REGULATORY FRAMEWORK 48

$\begin{array}{ll}\text { 3.1. The Institutional Framework } & 48\end{array}$

3.2. The Regulatory Framework $\quad 62$

$\begin{array}{lr}\text { 3.3. Summary } & 67\end{array}$

SECTION 4. ENVIRONMENTAL PROTECTION EXPENDITURES 69

4.1. Public Pollution Abatement And Control Expenditures - Capital Investment 70

4.2. Recurrent Expenditures - Budget Allocation 72

4.3. Wastewater Fees and the Vietnam Environmental Protection Fund 75

$\begin{array}{ll}\text { 4.4 Summary } & 76\end{array}$

SECTION 5. FUTURE DIRECTIONS

5.1. Prioritize Pollution Management Interventions for the Industrial Sector 77

5.2. Clarify Institutional Roles and Responsibilities for a More Effective Pollution Management 78

5.3. Strengthen Monitoring and Enforcement for Industrial Pollution 79

5.4. Rationalize Expenditure for Pollution Management and Control 80

BIBLIOGRAPHIC REFERENCES 81

ANNEX A. METHODOLOGY 85

ANNEX B. DETAILED POLLUTION ESTIMATES FOR PRIORITY SECTORS 96

ANNEX C. LEGAL INSTRUMENTS FOR INDUSTRIAL POLLUTION MANAGEMENT 115 
iv Rural Development, Natural Resources and Environment Unit of the East Asia and Pacific Region 


\section{ACKNOWLEOGEMENTS}

This report was prepared by a World Bank team led by Giovanna Dore (Environmental Specialist, EASRE) and including Philip Brylski (Sr. Environmental Specialist, EASES), Jostein Nygard (Sr. Environmental Specialist, EASRE), and Phuong Thi Thanh Tran (Sr. Environmental Specialist, EASRE). The International Centre for Environmental Management (ICEM) led by Jeremy Carew-Reid - and in collaboration with Benoit Laplante, Craig Meisner, Lothar Linde, Des Cleary, John Patterson, Nguyen Xuan Nguyen, Vu Xuan Nguyet Hong and Nguyen Thi Kim Dung - was responsible for the field and research work undertaken in September 2005, and in January 2007 in partnership with the Ministry of Industry (MOI) and Ministry of Natural Resources and Environment (MONRE).

Hoonae Kim (Manager, EASVS), Magda Lovei (Manager, EASOP), Rahul Raturi (Manager, EASRE) and Susan Shen (Lead Natural Resources Management Specialist and Sector Leader, EASRE) provided overall guidance to the team.

The team acknowledges the contribution and inputs of Truong Manh Tien (Ministry of Natural resources and Environment), Dang Tung (Ministry of Industry) of the Steering Committee, and of the MONRE and $\mathrm{MOI}$ members of the Technical
Advisory Group which reviewed and guided the study as it progressed; specifically: Le Minh Duc, Hoang Duong Tung, Pham Ngoc Dang, Nguyen Chu Hoi, Vu Tuong Anh, Dinh Huu Hoang and Nguyen Dang Minh, Nguyen Van Thanh, Nguyen Thi Lam Giang, Nguyen Van Tai, Nguyen Trung Thang, Do Thanh Bai, Le Minh Chau, Phung Chi Sy and Le Huy Ba.

The team is also grateful for the comments of peer reviewers Hocine Chalal (Sr. Environmental Specialist, MNSSD), Adriana Damianova (Lead Environmental Specialist, SASDN), Jane Nishida (Sr. Institutional Development Specialist, SASDN), and Hans Roland Lindgren (Director, Swedish Environmental Protection Agency).

Throughout the preparation of the report comments were also received by: Kulsum Ahmed (Lead Environmental Specialist, ENV), Dan Biller (Lead Environmental Economist, SASDN), Douglas J. Graham (Sr. Environmental Specialist, EASVS), Lasse Melgaard (Special Assistant, EACVF), Bekir Onursal (Sr. Environmental Specialist, EASRE), Bill Paterson (Lead Infrastructure Specialist, EASVS), Poonam Pillai (Environmental Specialist, ENV), Jiang Ru (Operation Officer, EASOP), Keiko Sato (Country program Coordinator, EACVQ); and Vivek Suri (Sr. Economist, PRMED). 


\section{ACRONYMS}

\begin{tabular}{|c|c|c|c|}
\hline \multirow[t]{2}{*}{ ALEP } & \multirow{2}{*}{$\begin{array}{l}\text { Amended Law on Environmental Protection } \\
\text { (2005) }\end{array}$} & MOF & Ministry of Finance \\
\hline & & MOFI & Ministry of Fisheries \\
\hline ASEAN & Association of South East Asian Nations & MOI & Ministry of Industry \\
\hline DEIAA & $\begin{array}{l}\text { Department of Environmental Impact } \\
\text { Assessment and Appraisal }\end{array}$ & MONRE & $\begin{array}{l}\text { Ministry of Natural Resources and } \\
\text { Environment }\end{array}$ \\
\hline DOE & Department of Environment & MOSTE & Ministry of Science, Technology and \\
\hline \multirow[t]{2}{*}{ DONRE } & \multirow{2}{*}{$\begin{array}{l}\text { Department of Natural Resource and } \\
\text { Environment }\end{array}$} & & Environment \\
\hline & & МOT & Ministry of Transport \\
\hline \multirow[t]{2}{*}{ DOSTE } & \multirow{2}{*}{$\begin{array}{l}\text { Department of Science, Technology and } \\
\text { Environment }\end{array}$} & MPI & Ministry of Planning and Investment \\
\hline & & NSEP & National Strategy for Environmental Protectior \\
\hline DWRM & Department of Water Resource Management & Politburo & $\begin{array}{l}\text { Political Bureau of the Communist Party of } \\
\text { Vietnam }\end{array}$ \\
\hline EIA & Environmental Impact Assessment & SEA & Strategic Environmental Assessment \\
\hline FDI & Foreign Direct Investment & SEDP & Socio-Economic Development Plan \\
\hline GDP & Gross Domestic Product & SOE & State-owned enterprise \\
\hline GSO & General Statistics Office & TSP & Total suspended particulate \\
\hline ICEM & $\begin{array}{l}\text { International Centre for Environmental } \\
\text { Management }\end{array}$ & USBTA & $\begin{array}{l}\text { United States-Vietnam Bilateral Trade } \\
\text { Agreement }\end{array}$ \\
\hline IPM & Industrial Pollution Management & VEPA & Vietnam Environment Protection Agency \\
\hline IPPS & Industrial Pollution Projections System & VND & Vietnam Dong \\
\hline ISO & International Standard Organization & VNEPF & Vietnam Environmental Protection Fund \\
\hline MARD & Ministry of Agriculture and Rural Development & VSIC & Vietnam Standard Industrial Classification \\
\hline MOC & Ministry of Construction & WTO & World Trade Organization \\
\hline
\end{tabular}




\section{EXECUTIVE SUMMARY}

\section{Background}

Vietnam's economy doubled in size during the last decade while its poverty rate was halved. Exports are growing by 20 percent per year, and foreign direct investment increases by 10 percent per year. Future rapid economic growth (an expected doubling of gross domestic product in the next 10 years), its associated industrialization and urbanization, and huge public investments in infrastructure pose great pressures on the environmental sustainability of Vietnam's development.

Because of the ongoing fundamental structural shift away from agriculture, forestry and fisheries toward industry, this document presents a review and analysis of industrial pollution from the manufacturing sector, based on field and research work undertaken for the World Bank by the International Centre for Environmental Management (ICEM) between September 2005 and January 2007, in partnership with the Ministry of Industry (MOI) and Ministry of Natural Resources and Environment (MONRE).

To allow for a better coverage of the different patterns and situations of industrial development in the country, the analysis was undertaken at five levels:

(a) National economy, industry sector, environment status.

(b) Manufacturing subsectors only the most important subsectors from an economic and pollution viewpoint were assessed in detail.

(c) Three economic development triangles - broad profiles were developed for each triangle and pollution estimates, and an environmental impact assessment (EIA) was made for each.

(d) Ten provinces with highest pollution load were identified for more detailed analysis to commune and factory level.

(e) Site specific - to gather "stories" and more detailed analysis, selected industrial zones and plants were assessed.
The pollution estimates presented in the analysis resulted from application of the Industry Pollution Projection System (IPPS). ${ }^{1}$ This model (described in Annex A) converts economic information into a comprehensive picture of pollution from manufacturing nationwide down to communelevel using Vietnam's most comprehensive industrial activity database from the General Statistics Office (GSO). It complements existing anecdotal field data and adds new information in areas where data does not exist or is unreliable. The IPPS spans 1,500 product categories, all operating technologies, and hundreds of pollutants. The research also builds pollution indexes and rankings as priority-setting tools; the resulting National Pollution Index combines separate indexes for air, land, and water pollution and rankings of sectors and geographic areas (e.g., provinces and communes) by pollution load.

Additional data and information complementing the IPPS comes from the GSO Annual Industrial Census since 2001. In addition, economic information on industry was gathered from other eight main sources: (a) GSO industry census, (b) $\mathrm{MOI}$, (c) Ministry of Agriculture and Rural Development (MARD), (d) Ministry of Fisheries (MOFI), (e) Ministry of Construction (MOC), (f) Ministry of Transport (MOT), (g) Ministry of Planning and Investments (MPI), and (h) individual provinces and industrial zones. Information on industrial environmental performance came mainly from Ministry of Natural Resources and Environment and Department of Natural Resource and Environment (DONRE) State of Environment Reports and from the national monitoring network. Other information came from each of the industrial management line ministries that have records. Finally, data and reports from international development agencies, local research institutions, and nongovernmental organizations were also used.

1. In 1995, a collaborative research effort between the Center for Economic Studies of the US Census Bureau, the US Environmental Protection Agency and the Policy Research Department of the World Bank resulted in the development of the Industry Pollution Projection System (IPPS). The IPPS would help environmental protection agencies, particularly in low and middle income countries, to address the need for data on pollution emission that would allow the design of costeffective regulation for pollution control and abatement. In the absence of detailed information on pollution emissions, IPPS serves as a first-order approximation until such time as locally monitored information can be substituted into the model to make it country specific. Because of this, and in spite of the significant crosschecking of data and analysis results, the information presented in this report must be considered an approximation. 


\section{Industrial Pollution Status and Pollution Index Ranking Analysis.}

Industry made up 41.5 percent of GDP in $2006 .^{2}$ The food and beverage sector, wearing apparel, tanning and dressing of leather, wood and wood products, fabricated metal products, and furniture are the most economically significant industrial sectors, with 65 percent of all industrial employment and 57 percent of all industrial firms in the country. Most industrial activity is located in five provinces - Ho Chi Minh City, Binh Duong, and Dong Nai in the South; and Hanoi and Hai Phong in the North - with 63.1 percent of all manufacturing employment and 54.7 percent of all industrial firms. Da Nang is the most important industrialized area in Central Vietnam, albeit to a much smaller extent. More than 80 percent of industrial activity is taking place within the 3 economic focal regions. Industrial estates are making a growing contribution to the economy. An additional 4,000 new industrial facilities are expected to be located within existing industrial estates and estates under construction. Thirty-five percent of all manufacturing enterprises will be located within industrial estates by 2010, most in Southern Vietnam. Handicraft villages are expected to continue expanding rapidly as a mechanism to achieve rural industrialization. Most craft villages are located in Northern Vietnam.

The manufacture of chemicals is of primary concern because of its relation to its impact on air, land and water pollution. The subsectors include the production of fertilizers, pesticides, and pharmaceuticals, and many industrial chemicals. The next most significant contributor to industrial pollution is to be found in those plants that process metals - iron, steel, and non-ferrous metals. The plants are involved in producing and shaping, treating and coating, and mechanical engineering of these metals. Even recycling of metal wastes appears in the top 30 for pollution load.
Tanneries and leather products, especially footwear, are a significant group of industries for pollution loading. The other manufacturing sectors on the top 30 list include those concerned with pulp and paper products, various kinds of wood products, and furniture. As one moves down the list, some sectors score highly only on one or two forms of pollution. For example, the paperboard industries have very high water pollution loadings but are of lesser concern for air and land pollution. Similarly, ceramics, cement, lime and plaster, vegetable and animal oils and fats, soap and detergents, electrical equipment, and refined petroleum products are all associated with industries that have a distinctive pollution profile. Yet, they require priority attention from environmental regulators because of their high overall pollution index rating. Of noted concern in Vietnam, the seafood processing stands out within the food processing industries because of its sheer scale of production and pollution load. It includes cold storing; freezing; drying; smoking and canning of fish, shrimp, squid, shellfish, algae, and other marine products. It also includes the production of fish oil and sauces, seasoning products, and fish meal. No other food processing subsector has the same level of overall environmental impact as fish processing and products.

The conventional air and water pollutants - PM-10 and total suspended particulates (TSP) - should be immediate targets for greater control. Each contributes 19 percent to the total air pollution load, and TSS makes up 86 percent of the pollution releases in water. Hazardous chemical and metal pollutants that should receive highest priority are:

(a) Chemicals and metals emitted to air. Toluene, ammonia, methylene chloride, carbon disulfide and benzene; lead, mercury, zinc and chromium;

(b) Chemicals and metals discharged to water. Sodium hydroxide, ammonia, hydrochloric acid, and nitric acid; and

2. The data source used in this exercise is the 2004 Enterprise Census from the General Statistical Office of the Ministry of Planning and Investment; enterprise information is collected according to the Vietnam Standard Industrial Classification (VSIC) system, which is based on the International Standard Industrial Classification system (Details of Revision 3.1, are described on the UN Statistics Office Website: http://unstats.un.org/unsd/cr/registry/regcst.asp?Cl=17). In the 2004 Census (used as a basis for this report), there were over 90,000 recorded enterprises spanning 14 industrial sectors. Since the interest here is to estimate industrial pollution from manufacturing activities, the sample is restricted to the manufacturing sector data within the Census. This includes 131 subsectors at the VSIC-4 unit of analysis. The GSO Census of 2004 covers 20,444 firms in the manufacturing sector, and 2,833,615 workers. This represented nearly 23 percent of all enterprises in the GSO 2004 Census and 53 percent of all employment. 
(c) Chemicals and metals discharged to land. Sodium hydroxide, aluminum oxide, sulfuric acid, and phosphoric acid.

Of the top 10 manufacturing subsectors releasing the highest pollution loads to the environment (for air, land, and water), the most serious polluters are industries producing fertilizer and nitrogen compounds and footwear. In addition, using measures of relative toxic hazard (using LD50 and LC50 values), the analysis found that subsectors associated with highly toxic materials include:

(a) Ceramics, cement, metal fabrication, electrical equipment and "other manufacturing" sectors for air pollution;

(b) Food processing, textile, and fertilizer sectors for land releases; and

(c) Fertilizer, pesticide, paper and paperboard, plastics and leather sectors for water pollution.

At provincial level, Ho Chi Minh City and Hanoi stand out as having the highest overall ranking on the National Pollution Index. ${ }^{3}$ Ho Chi Minh City scores highest on all four indexes. Of the provinces in the top 10 ranking, 4 are in the north, 1 in the center, and 5 in the south. Moving down the top ten pollution list, 2 clear pollution blocks or regions take shape -1 in the north of Vietnam stretching from Phu Tho Province west of Hanoi all the way to Haiphong and Quang Ninh on the coast; and the other in the south, made up of a solid block of provinces from Binh Duong and Dong Nai down to the sea. Data also shows an overlap between the provinces in the top 10 ranking with the Northern and Southern Economic Focal Regions (EFR). The fit between the most polluted provinces and the Economic Focal Regions is especially evident in the south. In the north, the provinces of Phu Tho and Thai Nguyen - ranked six and seven on the National Pollution Index fall outside the economic focal region but are intimately connected to it in a natural system and socio-economic sense. When the national pollution load is normalized by population, a similar pattern emerges for the highest pollution areas, even if the distribution is over a greater number of provinces.
At commune level, the Cam Gia Commune in Thai Nguyen Province comes out on top of the commune pollution ranking - but only 5 factories contribute most to the total pollution load in that commune. Interestingly, Hanoi does not have a commune in the national top 30. To get a better sense of the situation nationwide, the top 10 communes from Thua Thien Hue and Quang Nam Provinces (neighboring Danang) and Thanh Hoa were included in the ranking exercise. This brought in more of the provinces from central Vietnam even though they are relatively low on national rankings of provinces. It was found that $\mathrm{Ba}$ Dinh Commune in Thanh Hoa ranked second nationally, and that two communes from Thua Thien Hue are on the top 30 list. The extent to which pollution management plans can be finely targeted is illustrated in Duc - Giang Commune, Hanoi, where the basic chemicals sector, which comprises only 3 firms and employs only 6 percent of the manufacturing workforce, contributes 82 percent of the total pollution releases. The sector represents 69 percent of total air load, 93 percent of all land loadings, and 77 percent of all water loadings. The only other sector with a significant contribution is the veneer sheets and plywood sector with 18 percent of the water load.

Building on the above discussion, Table 1 presents the ranking of the top 10 provinces - and their communes with the highest pollution loads (highest in terms of the overall pollution load, across all three media). The provinces are listed in descending order of overall pollution index ranking. For the Central Economic Focal Region, only Danang appears in the top 10. Quang Nam and Thua Thien Hua are lowm on the National Pollution Index, ranking 25 and 27, respectively.

3. The National Pollution Index is calculated as the average of the air, land, and water indexes. The air index is first calculated as the simple average load for $\mathrm{SO}_{2}$, $\mathrm{NO}_{2}$, VOC, $\mathrm{PM}_{10}$, and TSP. Then each area or sector is then ranked in descending order of total load. The land index is calculated as the average load of 'chemicals to land' and 'metals to land'. The average is then rank orderd. The water index is the average of BOD, TSS, 'chemicals to water' and 'metals to water'. 
Table 1. Local government areas with highest pollution load - Top 10 provinces and their communes

\begin{tabular}{|c|c|c|c|c|}
\hline $\begin{array}{l}\text { Provinces with } \\
\text { highest pollution } \\
\text { loads }\end{array}$ & $\begin{array}{l}\text { Economic } \\
\text { Focal Region }\end{array}$ & Ten communes & lution loads & $\begin{array}{l}\% \text { of total } \\
\text { provincial } \\
\text { pollution load } \\
\text { in ten top } \\
\text { communes }\end{array}$ \\
\hline 1. Ho Chi Minh City & South & $\begin{array}{l}\otimes \text { Nguyen Thai Binh } \\
\text { Ben Thanh } \\
\text { Tan Thuan Dong } \\
\text { 叉 Truong Tho }\end{array}$ & 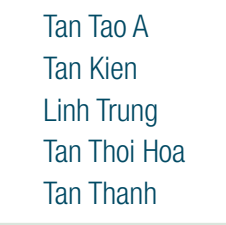 & 49 \\
\hline 2. Hanoi & North & 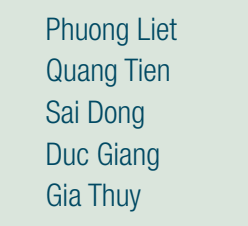 & 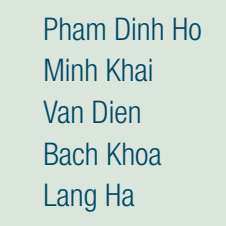 & 33 \\
\hline 3. Hai Phong & North & 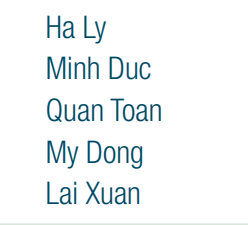 & 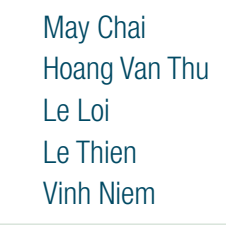 & 70 \\
\hline 4. Binh Duong & South & 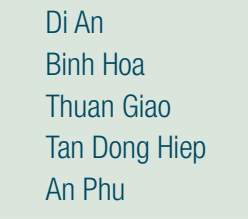 & 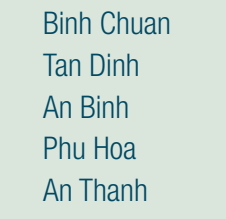 & 77 \\
\hline 5. Dong Nai & South & 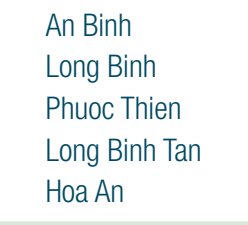 & 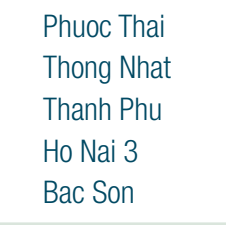 & 82 \\
\hline 6. Thai Nguyen & - & 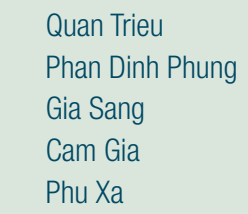 & $\begin{array}{l}\otimes \text { Trung Thanh } \\
\otimes \text { Tan Thanh } \\
\otimes \text { Tan Long } \\
\otimes \text { Tan Quang } \\
\otimes \text { Cao Ngan }\end{array}$ & 97 \\
\hline
\end{tabular}




\section{Provinces with}

highest pollution

loads

Economic

Focal Region

\section{Ten communes with highest pollution loads}

$\%$ of total

provincial

pollution load

in ten top

communes

\begin{tabular}{|c|c|c|c|c|}
\hline 7. Phu Tho & - & $\begin{array}{l}\boldsymbol{\nabla} \text { Viet Tri } \\
\nabla \text { Tien Cat } \\
\nabla \text { Tho Son } \\
\nabla \text { Ben Got } \\
\nabla \text { Thuy Van }\end{array}$ & 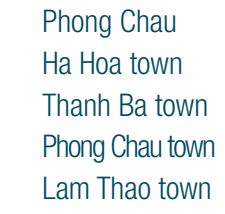 & 96 \\
\hline 8. Da Nang & Central & 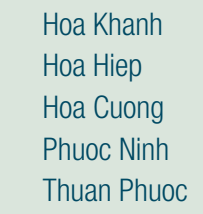 & 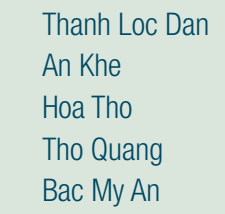 & 88 \\
\hline 9. Ba Ria Vung Tau & South & 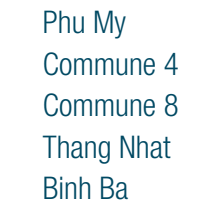 & 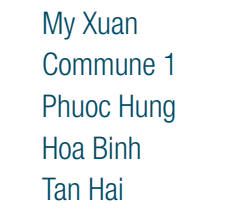 & 78 \\
\hline 10. Can Tho & - & 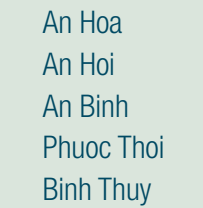 & 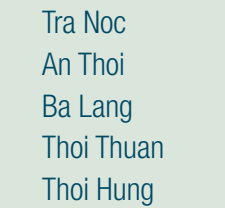 & 96 \\
\hline
\end{tabular}

Source: Authors 


\section{Global Integration of the Industrial Sector}

Trade liberalization and export promotion have been central to Vietnam's continuing economic transition and rapid industrialization. Vietnam has pursued a multi-pronged approach to gradually reducing trade barriers and increasing the outward orientation of the economy. The Government's commitment to trade liberalization has been fueled to a large extent by bilateral and multilateral trade agreements. Under the ASEAN Free Trade Agreement (AFTA, 1995), tariffs on imports from ASEAN countries were reduced to below 20 percent and are targeted to be below 5 percent by 2006. Under the 2001 United States-Vietnam Bilateral Trade Agreement (USBTA), Vietnam made substantial further commitments to liberalize its trade regime, including tariff reduction and removal of quota restrictions. The USBTA has provided a sizable stimulus to exports, with exports to the United States increasing by 128 percent and making up 82 percent of total export growth in 2002. The composition of Vietnam's exports and imports has also altered significantly during this period. While the share of crude oil in total exports declined from one-third in the early 1990s to one-fifth by 2002, manufacturing exports rose from 6 percent to 32 percent. There has been a significant diversification in Vietnam's export markets as well. With Vietnam becoming less dependent on oil exports, Japan and Singapore have become less important export markets. The European Union and the United States of America have become major markets for manufactured goods, such as textiles, garments, and footwear.

Significant developments are expected following Vietnam's accession to the World Trade Organization (WTO). ${ }^{4}$ In general, the average tariff rate on the import of manufactured goods into Vietnam will be reduced from approximately 18 percent to 12.5 percent, making the export of manufactured goods to Vietnam more competitive. In addition, a large number of subsidies and tax incentives provided by the Government of Vietnam to the industrial sector are prohibited by the WTO and will have to be phased out. ${ }^{5}$ While Vietnam will benefit from a greater access to world markets, its industrial sector will face a much greater level of competition, particularly in the following areas:

- Chemicals, cosmetics and pharmaceuticals. Vietnam has committed to reduce tariffs to the harmonization rates set by the Chemical Harmonization Agreement on 80 percent of chemical products. Vietnam's average tariff on cosmetics, a subsector in chemicals, will be reduced from 44 percent to 17.9 percent upon full implementation. Pharmaceutical tariffs will average 2.5 percent within 5 years after accession.

- Motor vehicle parts. Tariffs on auto parts will be reduced by 19 percent to an average of 13 percent. Vietnam will also reduce its tariff on large motorcycles by 56 percent and motorcycle parts by 32 percent after full implementation.

- Agriculture and construction equipment. Vietnam will reduce tariffs to 5 percent or less for close to 90 percent of its tariff lines.

- Wood products. Vietnam's average tariff on wood products will be approximately 4 percent upon accession.

- Textile and garment. Removal of export quotas for Vietnamese exports of textile and garments. Removal of US\$4 billion subsidies provided by the Vietnamese government to the textile and garment sector within the next 5 years. Levies against imported garments and textiles are to be lowered to 10-15 percent from current 40-50 percent.

4. Accession approved by the WTO General Council on November 7, 2006. For more details, see Trade Facts, May 31, 2006 (published by the Office of the United States Trade Representative, Executive Office of the President of the Unites States).

5. For example, Decree 164 on the implementation of the Law on Enterprise Income Tax provides that a company having an export sales volume of more than 50 percent of the total value of goods produced qualifies for a 20 percent tax rate for 10 years from the commencement of business operation, a two-year tax exemption, and a subsequent 3-year, 50 percent tax reduction from the first profitmaking year. Companies exporting 100 percent of their production enjoy a 10 percent tax rate for 15 years from the commencement of business operation, a 4-year tax exemption and a subsequent 7 -year, 50 percent tax reduction. Such tax incentives are expected to be in violation of the WTO Agreement on Subsidies and Countervailing Measures. Vietnam's Ministry of Finance recognizes that exports subsidies of this nature will have to be gradually reduced as Vietnam joins WTO. 
- Ferrous and other scrap metals. Vietnam will reduce export duties on such metals by up to 51 percent of current levels over the next 5 to 7 years.

- Information technology products. Upon accession, Vietnam will join the Information Technology Agreement, which eliminates tariffs on information technology products including computers and cell phone.

Vietnam's WTO accession is thus expected to have an impact on its foreign trade in terms of volume and structure. Based on Vietnam's known comparative advantages, the following changes may be expected in the short to medium term:

- Labor intensive industrial sectors, such as handicraft as well as textiles and garments, may further expand (relative to a scenario where Vietnam would not accede to WTO). However, Vietnam's comparative advantage in such sectors (especially the textile and garment sector) may be offset by the removal of various subsidies currently supporting them. Firms heavily dependent on subsidies will need to rationalize their operations to benefit from Vietnam's accession to WTO. In all likelihood, some will not be capable of doing so.

- Land intensive industries, such as plantation, grain production, and traditional husbandry, would decrease. This is the case as Vietnam's explicit policy is to industrialize its rural sector.

- Capital intensive industries and services would increase significantly, including banking, security, insurance, brokerage, tourism, real estate, and education.

Changes to the nature and path of industrialization are expected to take place only gradually and over a relatively long period of time. In most cases with the possible exception of the textile and garment sector, import duties and export subsidies are reduced rather than being eliminated; and this will happen over a period of 5 to 10 years. Also, Vietnam membership in the ASEAN Free Trade Agreement, and the USBTA have facilitated the implementation of reforms to its import and export tariff and non-tariff system. With WTO accession, Vietnam will consolidate those revisions; yet, the scale and importance of the challenges ahead should not be underestimated particularly because the Vietnam Government's ability to respond to the challenges of increasing integration in the world economy suffers from a number of significant constraints.

The overall competitiveness of Vietnam's industrial sector is limited and weak, and is currently characterized by low productivity, low and outdated technological standards, and high production costs. ${ }^{6}$ The operational effectiveness of state-owned enterprises is low. Despite (or because of) this low productivity, state-owned enterprises, especially large state corporations, continue to benefit from privileged access to land use, capital, and various forms of tax exemptions and subsidies. The state-owned enterprises reform process has been slow and mainly implemented in enterprises with small capital. Large corporations owning hundreds of enterprises have remained in the hands of the state. Despite its dynamism and increasing importance in the economy, the non-state sector is currently made up of small and medium enterprises with limited access to capital for undertaking investments in new technology. Finally, the structure of labor supply remains unsuitable for a technologically advanced industrial sector as Vietnam is still characterized by a large pool of insufficiently trained labor and an inadequate supply of highly skilled workers.

\section{The Institutional and Regulatory Framework}

\section{The Institutional Framework}

The evolution of environmental institutional arrangements in Vietnam began during the mid-1980s with institutional reforms and the launching of a five-year national research program on environmental studies. The Ministry of Science, Technology

6. According to assessment and comparison of 2004-2005 data, Vietnam's business competitiveness index ranks 79 out of 103 countries, and its national general competitiveness index in global comparison ranks 77 out of 104. The country's economic development is still at a low level. Even in information technology, which records the highest acceleration in Vietnam, still ranks at 68 out of 102 countries. The comparative corruption index published by Transparency International, reflects the seriousness of this issue in Vietnam, which ranks 102 out of 144 countries. In terms of business operation and strategies as well as national business environment, Vietnam is behind other countries in the region like China, the Philippines, Indonesia, Malaysia, and Thailand, and well behind South Korea and Singapore. 
and Environment (MOSTE) and its National Environment Protection Agency was created in 1993/4. In the following decade significant innovation in environment policy and management systems took place with an expanding provincial network of Departments of Science, Technology and Environment. In this early period, the basic framework for pollution control, Environmental Impact Assessment, and national monitoring and reporting were set in place. However, the policy, legislative, and institutional expansion and innovation moved well beyond the capacities of staff, budgets, and structures to manage effectively, especially at local level.

Pollution monitoring and management of natural resources are inextricably linked. In Vietnam, these responsibilities are spread between the 'environment' part of the Ministry of Natural Resources and Environment - Vietnam Environmental Protection Agency (VEPA), Department of Environment (DOE), Department of Environmental Impact Assessment and Appraisal (DEIAA), and Department of Water Resources Management (DWRM - which is implementing key aspects of pollution control in relation to water. However, as the development and implementation of a strong and strategic framework for pollution control matures and develops, its focus is likely to shift from the control of single-point sources of pollution to control of all forms of pollution at the enterprise level. Institutional responsibilities will also evolve to reflect these changing requirements. For the immediate future, the most critical issue is to strengthen the integration and cooperation between the various organizations and agencies that share responsibilities for environmental management. The current system does provide strong incentives for building working relations with decentralized institutions at local government level. But there are few similar incentives to promote lateral relations, for example, between MONRE core environment organizations and the various sectoral ministries responsible for managing industries. Those incentives need to be put in place, beginning with their strong emphasis in the MONRE mandates and its various institutional components.

The 3rd Plenum of Term VIII of the Party's Central Committee in June of 1997 decided the following:
Based on the united management of central State of institutions, and of strategies and plans for development of all sectors and the national economy, it is necessary to decentralize clearly and reasonably administrative responsibilities and competencies to facilitate and increase the autonomy of local governments, exploring all potentials for local social and economic development.

In the context of the ongoing decentralization, the Ministry of Natural Resources and Environment has undertaken a series of internal reviews; the 2005 internal review found that the legal basis for the decentralization of environmental protection functions is adequate. In Statement No. 17/TTr-BTNMT of May 20, 2005, the Ministry of Natural Resources and Environment submitted to the Government the "Decentralization of state management of environmental protection" program. The Government found that MONRE actions toward decentralization had been appropriate, taking into account progress in decentralization of strategies, plans, and implementation; environmental impact assessment and appraisal; the management of monitoring systems; state of environmental reporting; forecasting of environmental change; certification based on environmental standards and other environmental permissions; inspection, examination and supervision of environmental dispute resolution; and administrative punishments for violations on environmental protection. This review however also emphasized the need to develop and improve the capacity for environmental management in ministries, sectors, local areas, industrial zones, and export processing zones.

The provincial Departments of Natural Resources and Environment were established and former Departments of Science, Technology and Environment renamed as Department of Science and Technology in 2003.7 The provincial Departments of Natural Resources and Environment were formed by merging the former Department of Land Administration and other organizations responsible for water and mineral resources and the environment within the Department of Agriculture and Rural Development; the

7. Action taken by Government Decision No. 45/2003/QD-TTg dated on 2 April 2003. 
Department of Industry; and the former Department of Science, Technology and Environment. The Ministry of Natural Resources and Environment and Ministry of Home Affairs issued several secondary legal instruments to guide local authorities in setting up Departments of Natural Resources and Environment in provinces and the centrally run cities.

The Ministry of Natural Resources and Environment and the Ministry of Internal Affairs issued a joint circular setting out the guiding powers, tasks, and organization of functional agencies that support the Provincial Peoples Committees in managing state natural resources and the environment at the local level. ${ }^{8}$ According to this joint circular, the Department of Natural Resources and Environment is an agency of the Provincial Peoples Committee, responsible for supporting the Committee in state management with issues related to land, water resources, minerals, environment, hydrometeorology, and mapping in the province; and reporting administratively to the national government. On technical matters, the Departments of Natural Resources and Environment work with Ministry of Natural Resources and Environment but the establishment of functional divisions within the Departments is decided by the Provincial Peoples Committee in consultation with the Ministry.

Policy, institutional and legal instruments for environmental protection, and industrial pollution management have been issued by the Politburo, the Government of Vietnam, and the Ministry of Natural Resources and Environment. Strategies and plans for implementation of industrial pollution management have been approved or tabled by the Government, Ministry of Planning and Investment, and by the Ministry of Natural Resources and Environment ${ }^{9}$ and some Departments of Natural Resources and Environment. ${ }^{10}$ However, a continuous refinement of roles and responsibilities for all institutions involved in industrial pollution management (IPM) is needed. The institutional framework and mandate for the decentralization of environmental management to the Provincial Peoples Committee, Departments of Natural Resources and Environment, and other agencies and organizations has evolved rapidly over the past decade. Some decentralized agencies have shown remarkable achievements in capacity development in industrial pollution management despite being almost overwhelmed by the industrial growth and expansion in their provinces.

Therefore, of great significance will be the strengthening of the Ministry of Natural Resources and Environment - and possibly of the Departments of Natural Resources and Environment - and the roles and responsibilities of Provincial, District, and Commune Peoples Committees and their jurisdictions and working relationships with each other. The need for a sharply focused national pollution control approach is more pressing than ever. The demands on the Vietnam Environmental Protection Agency and Department of Water Resources Management during the next decade in building the capacities for industrial pollution management with development sectors at local level, and with the private sector will intensify. The Vietnam Environmental Protection Agency and Department of Water Resources Management will need to take the lead in that work and to collaborate together closely. A great deal of investment in time and resources will be required in outreach, with the Ministry of Natural Resources and Environment facilitating and guiding other actors in taking on their more rigorous pollution prevention and control responsibilities. Equally important, will be the clarification of the roles and responsibilities of those ministries with dual responsibilities (ownership and control of industries and industrial parks) at national and decentralized levels. ${ }^{11}$ Furthermore, the clarification of roles and responsibilities for IPM policy tools need attention, and determined implementation by government at national and decentralized levels goes hand in hand.

8. Inter-Circular No. 01/2003/TTLT-BTNMT-BNV. 15 July 2003; and Circular No. 1694/2003/TTLT-BTNMT-TCCB. 18 July 2003

9. Notably Decision No. 328/2005/QD-TTg. Approval of National Plan for Environmental Pollution Control until Year 2010.

10. Provincial Industrial Pollution Management Plans of Ha Noi, Hai Phong, Da Nang, Binh Duong, Long An, Bac Ninh and Hai Duong were presented to the MONRE Minster at the Final Project Steering Committer of the Vietnam-Canada Environment Project, 04 May 2005.

11. Notably the MOI, MOC, MOT, MPI, and their Departments in the provinces and districts. 


\section{The Legislative Framework}

To implement the environmental protection and natural resource management policies, the Government has enacted and promulgated the following laws of importance for pollution management. The Amended Law on Environmental Protection (ALEP), which was approved by the National Assembly in 2005 after broad consultation and many revisions, is one of the key legislative tools to help improve the environmental performance of the industrial sector. It provides the coverage for application of industrial pollution management policy tools and the basis for environmental standards, including those for waste discharge; and establishes the requirements for strategic environmental assessment reports. As such, ALEP offers a comprehensive basis for improving environmental management in Vietnam, and it is important to improve and strengthen the environmental performance of the industrial sector at national and local level. However, as many of its provisions are new and guidelines on their application need to be developed, awareness raising is needed for ALEP to become more effective and better understood in the community. Also of relevance are the Law on Land (2003) and related Order No. 23/2003/L-CTN of December 10, 2003, on the promulgation of the Land Law and Decree on the implementation of the Land Law; and the Law on Water Resources (1998) and Decree No. 179/1999/ND-CP of December 30, 1999 on the implementation of the Law. In addition, other recently promulgated legal instruments particularly for environmental protection - include targeted initiatives at severe polluters, sanctions for administrative violations, pollution charges, licensing water usage and discharges, and establishment of an Environment Fund. ${ }^{12}$

Finally, the strategy for implementation of the SocioEconomic Development Plans for 2001-2010 acknowledges that rapid development and economic growth must proceed in parallel "with realization of social equality, progress, and environmental protection" and includes specifics on environmental protection, conservation of natural resources, and sustainable development.

\section{Environmental Protection Expenditures}

In 2004, the Government of Vietnam decided to increase public environmental protection expenditures to 1 percent of the overall budget (Resolution of the Political Bureau, No. 41$N Q / T W$ ). Challenges remain in defining and classifying the various components of environmental protection expenditures, including those for pollution abatement and control, and then in estimating expenditure for each component. Effective progress in industrial pollution management requires governments have the capacity to keep track of past, current, and future investment flows. Yet, environmental authorities in Vietnam have difficulty in assessing funding needs from year to year in part due to uncertainty on what 1 percent of the overall budget means in practice. When first introduced, it was not even clear if 1 percent represented an increase or a reduction in levels of environmental expenditure although the Government's intent was to increase its commitment.

There is growing pressure on the Government to raise public expenditure on pollution control and to force business to do the same. The costs to the economy of pollution, which is increasing in volume and toxicity, are becoming evident to the Government and public at large. In a recent report prepared by the World Bank and the Chinese government, it was estimated that environmental pollution cost China about US $\$ 88$ billion in economic losses in 2003 , accounting for 5.4 percent of GDP. ${ }^{13}$ The environmental costs of air and water pollution accounted for 71 percent and 29 percent, respectively, of the total combined costs. These figures cover (a) public health, agricultural, and materials losses caused by air pollution; and (b) public health, industrial, and agricultural production losses and water shortage caused by water pollution. It does not account for groundwater or soil contamination. In 2004, Vietnam's GDP reached approximately US $\$ 45$ billion (GSO, 2006). This review has not attempted to undertake a similar costing exercise as in China. However, assuming that a figure of the same order of magnitude prevails in Vietnam (i.e., 5.4\% of GDP), then the environmental cost of pollution in Vietnam would have reached about US\$2.5 billion.

12. Decision No. 64/2003/QD-TTg. April 22 2003; Decree No. 121/2004/ND-CP, May 12, 2004;Decree No. 67/2003/ND-CP, June 13 2003; Prime Ministers Decree 149/2004/ND-CP, July 27, 2004; and Decision No. 82/2002/QD-TT, June 262003.

13. World Bank (2008), Cost of Pollution in China - Physical and Economic Damages. Draft version of March 2008. 
According to the information available in the MPI Public Investment Programs and UNDP Compendium, over the period 1996-2005, there were 145 projects related to pollution abatement and control. Annual expenditures increased significantly over the period 2000-2005 to reach approximately US\$600 million in 2005. These expenditures reached a cumulative level of US\$1.5 billion for the period 1996-2000, and approximately US\$2.3 billion for the period 2001-2005 indicative of a new level of attention and priority given to pollution control and abatement.

In 2001, as it was then reported by the National Environment Agency, Vietnam Dong (VND) 102,970 million (or approximately US\$6.56 million) was spent on environmental protection activities in general. Approximately 90 percent (or VND 91,580 million) was allocated to central-level ministries and agencies. The remainder (approximately 10 percent) was allocated to provincial and local authorities. In 2001, the then Ministry of Science, Technology and Environment was responsible for assessing the budgetary needs of various organizations and distributing the funding. It should be noted that in 2001, the "National program on clean water and sanitation in rural areas" had its own budget line, separate from other environmental protection activities, amounting to VND 159,950 million (or US\$10.2 million).

\section{Opportunities for the Future}

Vietnam is one of the fastest-growing economies in the world - averaging 8 percent increase in GDP annually during 2004-2005 - and is changing rapidly across many fronts. The findings of the review and assessment of pollution from manufacturing sectors in Vietnam suggest that industrial pollution is highly concentrated in certain areas of the country, and originates from a few manufacturing subsectors. Environmental management effort focused on those areas and subsectors would yield significant pollution reduction benefits.

The systems of governance are under continuous change through the Public Administrative Reform process and as new international and domestic challenges arise. Accession to the WTO and entry into other international agreements are adding to the scale and momentum of change. Each new law adopted by the National Assembly sends powerful waves of reform through all levels of government and other sectors as broad policies and commitments are expressed in detailed implementation arrangements. Complex statutes, such as the Amended Environmental Protection Law, have far reaching repercussions throughout society; and the relationships among government, business, and communities are adjusting in fundamental ways as a result. It is apparent from the analysis in this report that environmental capacity and investment is falling well behind the levels required to bring the transformation under control in spite of Government efforts to respond to these changes.

The Government can raise the bar in the following areas as a means to address the growing challenges derived from increasing pollution loads, concentrations, and toxicity from industry:

(a) Prioritize pollution management interventions for the industrial sector. There is the need to rationalize and strengthen ongoing efforts to identify the most important pollutants, enterprises, and areas for priority attention at national and local level. Issues related to the 'most polluting industries' and 'hazardous pollutants' are addressed in general within the Amended Law on Environment Protection 2005, the National Strategy for Environmental Protection to 2010 (NSEP), Resolution 41/2004 of the Political Bureau, and specifically for 'most polluting industries' by Decree 64/2003. The other three priorities (contaminated sites, industrial zones, and craft villages) have not been subject to systematic policy analysis and strategic actions by government in terms of industrial pollution management. With limited resources and capacities, it is not possible to start everywhere at once. In the case of the most polluting industries, there is already a good policy framework and program in place. It requires further elaboration and continuous fine-tuning as more and more serious polluters are effectively managed. Also, innovative financing options might be required for pollution control in the most seriously polluting industries. Many enterprises are unable to solve or invest in waste treatment systems. They are economically marginal and do not have the resources to invest in what they consider to be nonproductive activities to control pollution. 
(b) Clarify institutional roles and responsibilities for a more effective pollution management. The Government has been progressively reforming the basis of its public administration to be open and transparent, participatory and equitable, efficient and effective. The Ninth National Party Congress (April 2001) set out a series of Public Administration Reform policies and measures. ${ }^{14}$ Prime Ministerial Decision No. 136/2001/QD-TTg approved the Public Administration Reform Master Programme for the 2001-2010, which provides the basis for on-going reform to public administration. Responsibilities for pollution management span many fields, and no single agency can manage all the processes that influence environmental quality. A cross-agency, collaborative approach under a lead agency is essential. In addition, to ensure that significant progress is made in the shortto-medium term, the Ministry of Natural Resources and Environment and the other ministries should promote the establishment and/or strengthening of environmental units in sectoral agencies. The Government has long called for the establishment of environmental units within all sectors. Further progress in industrial pollution management will be seriously constrained until that directive is met and adequate staffing and budgets are provided. Line ministries and their provincial counterpartsmustestablishenvironmentalmanagement units and clearly define their functions, authority, and relationships with the Ministry and Departments of Natural Resources and Environments.

(c) Strengthen monitoring and enforcement for industrial pollution. Despite recent and significant efforts to increase the staffing, resources, and capacity of local authorities to monitor the behavior and environmental performance of industrial facilities, the monitoring system remains weak. While increasing capacity may contribute to alleviating this weakness, other important issues need to be addressed. Improved monitoring should also be accompanied by strong enforcement. They work in tandem to create incentives for pollution prevention and control. While raising existing level of fines is justified, fines for noncompliance with environmental regulatory requirements should not be limited to their conventional forms (such as administrative or civil fines). The concept of penalties has to be considerably broadened to include (among other possibilities) the public disclosure of inadequate environmental performance, reduced or limited access to capital markets, reduced or limited access to public sector contracting, and properly designed benchmarking system. Also disclosure of environmental performance of local authorities accompanied with a system of rewards could be effective in shifting attention to environmental quality at local levels.

(d) Rationalize expenditure for pollution management and control. The recent commitment to devote 1 percent of budget expenditures to environmental protection activities followed with the adoption of Decision No. 70 offering a new opportunity to set in place a comprehensive tracking system is intended to address many of the inefficiencies in the expenditure allocation and management for the industrial sector. Particular attention should be given to setting up a system that allows a systematic and comprehensive collection of data on environmental protection activities and pollution abatement and control expenditures on an annual basis. Such data should form the basis of reporting, monitoring, and priority setting.

14. These include applying the principles of multi-sectoral management; delegation and decentralization; separating the state management function from production and business activities, and public administration agencies from public service delivery agencies; further reforming state-owned enterprises; and a range of administrative procedures and adjustments to structures and functions. 


\section{INTRODUCTION}

Between 1990 and 2005, Vietnam achieved an average annual growth rate of 7.5 percent in gross domestic product (GDP). The industrial sector was the most significant driver of this economic expansion with an annual growth of rate of more than 10 percent, at a time when agriculture, forestry, and fisheries grew at an annual average rate of less than 4 percent. Such structural shift is in line with the National Socioeconomic Development Plan 2006-2010, which calls for an annual growth of 10 percent for the industrial sector (with a particular focus on the manufacturing sector, where a sustained annual growth of 15 percent is expected) and with international good practice in industrialization and modernization policies.

This report was originally initiated under the concept of a country environmental analysis for Vietnam; however, during its development, and in consultations with Vietnamese counterparts, it was decided to limit the focus of the report to trends in industrial development, with particular attention to the environmental challenges of manufacturing industries, and the existing regulatory and institutional framework for environmental management - including issues relating to decentralization and policy coordination. The environmental challenges deriving from the accession to World Trade Organization (WTO) are also an important focus. As such, this report is intended to be a contribution to a general countrywide environmental analysis but not constituting one of its own.

\section{The Industry Pollution Projection System}

The pollution estimates presented in this review report results from the application of the Industry Pollution Projection System (IPPS). This model (described in Annex A) is the result of a 1995, collaborative research effort between the Center for Economic Studies of the US Census Bureau, the US Environmental Protection Agency and the Policy Research Department of the World Bank. It resulted in the development of the Industry Pollution Projection System (IPPS) with the objective to help environmental protection agencies, particularly in low and middle income countries, to address the need for data on pollution emission that would allow the design of cost-effective regulation for pollution control and abatement (Hettige et al. 1995).
The IPPS combines data on pollution information emissions in order to calculate pollution intensity factors (or coefficients) per unit of industrial activity. Pollution intensities have initially been calculated with data available in the United States from the U.S. Manufacturing Census and the U.S. Environmental Protection Agency (USEPA). The basic calculation took manufacturing information on output value, value-added, and employment and then matched this with the USEPA database on pollution releases on a plant-by plant basis. Pollution intensities were then calculated as the total amount of releases divided by the manufacturing indicator (i.e., output value, value added, or employment). In the case of the employmentbased indicator, that figure is the number of kilograms of pollutant per unit of employment, since it has been shown to be much more stable across different technologies and across both developed and developing countries (Dasgupta and others, 2002). The USEPA contains emissions information for pollutants and chemical substances known to be harmful to both human health and the environment. The IPPS coefficients are available for the following list of pollutants:

- Air pollutants. Sulfur dioxide $\left(\mathrm{SO}_{2}\right)$; nitrogen dioxide $\left(\mathrm{NO}_{2}\right)$; volatile organic compounds (VOC); and particulate matter, both total suspended particulates (TSP) and particulate matter of size less than 10 microns $\left(\mathrm{PM}_{10}\right)$.

- Water pollutants. Biological oxygen demand (BOD) and total suspended solids (TSS).

The IPPS also includes pollution intensities for over 240 priority chemicals and metals released to air, water, and land. Listed below are some of the chemicals known to be toxic to human health and metals known to be bio-accumulative:

- Chemicals. Benzene, chloroethane, chloromethane, toluene, and zylene;

- Metals. Antimony, arsenic, asbestos, beryllium, cadmium, chromium, copper, cyanide, lead, mercury, nickel, thallium, and zinc.

For each of the air and water pollutants and the 240 toxic chemicals and metals, IPPS provides a lower-bound value for the pollution intensity coefficients, an upper-bound value, and an inter-quartile mean value. For the purpose of this report, estimates of pollution load are based on the lower-bound value of pollution intensity. It was decided to adopt the more conservative measure of pollution intensity. Therefore, 
pollution release estimates presented in this report are to be interpreted as under-estimates of the actual pollution releases. However, in the context of this report, and for priority setting in general, what matters most are the relative rankings of one sector or area over another.

To factor toxicity into the analysis of IPPS pollution loads, estimates are weighted by a relative toxicity factor or threshold limit values produced by the internationally recognized American Conference of Governmental Industrial Hygienists (1999). These toxicity factors are a culmination of epidemiological evidence and occupational health and safety standards typically adopted worldwide (including the United States). The calculation procedure essentially multiplies the estimated pollution load by the relative toxicity factor of the substance to yield a toxicity-weighted pollution load. For example, if a particular substance were more toxic, the pollution load would receive a greater weight than if the substance were relatively benign. Thus substances that are relatively more toxic would rank higher owing to weighting scheme. To calculate the relative hazard risk, the pollution load estimates are also categorized into three ranges of acute exposure hazard using lethal concentration (LC50) and lethal dose (LD50) values (Horvath and others, 1995; Swanson and others, 1995). These measures form the basis of epidemiological impact studies in evaluating the potential risk to human life. In this report, each chemical in the database was classified as a (1) high hazard, (2) moderate hazard, or (3) low hazard according to its LC50 and LD50 value and then aggregated up to the plant level and summarized at the provincial, commune, and sector level.

The key piece of information required to calculate pollution load in Vietnam is the scale of manufacturing activity. The data source used in this exercise is the 2004 Enterprise Census from the General Statistics Office (GSO)..$^{15}$ Information on industrial environmental performance came from State of Environment Reports of the Ministry and Departments of Natural Resources and Environment (MONRE and DONRE), in addition to those of the national monitoring network and in varying degrees from each of the industrial management line ministries that have records. Data and reports from international development agencies, local research institutions, and nongovernmental organizations were also used. Enterprise information is collected according to the Vietnam Standard Industrial Classification (VSIC) system, which is based on the International Standard Industrial Classification (ISIC) system (Revision 3.1). In the 2004 Enterprise Census, there were over 90,000 recorded enterprises spanning 14 industrial sectors. Since the interest here is to estimate industrial pollution from manufacturing activities, the sample is restricted to the manufacturing sector data within the Census. This includes 131 subsectors at the VSIC-4 unit of analysis. The 2004 Census covers 20,444 firms and 2,833,615 workers in the manufacturing sector. These census figures represent nearly 23 percent of all enterprises and 53 percent of all employment.

One noted limitation of the GSO data set is that some of the observations were from the headquarters of a company that also had operations in other locations. To test the extent to which this was true, a field study was conducted by selecting the top 2 communes in each of the top 10 provinces in terms of the IPPS-estimated pollution load. Then the top 2-3 most polluting factories and their commune location were identified. Field operators then placed a phone call to the factory to substantiate its location. If a factory could not be contacted, a call to the relevant provincial Department of Natural Resources and Environment was placed. Since the factories were serious polluters, in most cases the Departments were aware of the factories and could pinpoint their location. This was not always the case. During informal discussions, it was noted that some of the most seriously polluting factories were not in the identified communes. The addresses given were only for headquarters' administration purposes.

The degree of bias this phenomena introduces is unknown, however the magnitude of this bias diminishes with greater aggregation of analysis. At the provincial level, it may not be a concern at all since most operations, including the headquarters, may co-locate in the same province. However at levels of aggregation smaller than the commune level,

15. The 2004 GSO Enterprise Census data was collected from the Ministry of Planning and Investment (MPI), Ministry of the Interior (MOI), Ministry of Agriculture and Rural Development (MARD), Ministry of Fisheries (MOFI), Ministry of Construction (MOC); Ministry of Transport (MOT), and individual provinces and industrial zones. 
results are not fully reliable. Field observations will play a critical role in the follow-up to this exercise report and to future monitoring activities. The report should also lead to further discussions with the General Statistics Office on improving the coverage of the census and the method of collection so that satellite plant locations are fully and accurately accounted for in the annual roster. These suggestions and others are described more fully in subsequent chapters.

One common question that arises when IPPS is used in a developing country context, such as Vietnam is, how realistic is it to use coefficients derived from data in the United States? The answer is two-fold. In the absence of detailed information on pollution emissions, IPPS serves as a first-order approximation until such time that locally monitored information can be substituted into the model to make it country specific. Another reason for using IPPS lies in understanding whether Vietnamese industrial technology is well-represented by the underlying technology reflected in IPPS. The coefficients derived for IPPS were based on 1987 emissions profiles for over 20,000 plants in the United States. Many existing industrial operations in Vietnam use technologies over 15-20 years old similar to those operating in the United States in the late 1980s and early 90s (although in some sectors such as seafood processes, technologies are changing rapidly). Most important, the coefficients used in this report are lower bounds, i.e., resulting in the most conservative pollution estimates based on the US technology inherent in the coefficient structure.

In the case of Vietnam, some monitored information on pollution is available; however, it is not collected on a systematic and comprehensive basis and does not cover as many pollutants or sectors as in the IPPS. This provides some evidence to the question, does the underlying Vietnamese technology conform well with the technology inherent in the US-based IPPS coefficients? To test this proposition, pollution coefficients for BOD and TSS were obtained from the CTC Vietnam and from the Vietnam-Canada Environment Project. Since the CTC database of coefficients included coefficients for 54 sectors measured in terms of manufacturing employment, this facilitated a comparison with the IPPS coefficients used for this exercise (employment-based coefficients). Rank correlation coefficients were calculated between estimated BOD and TSS loads using both CTC and
IPPS coefficients. The results suggest that at the provincial level the correspondence is high while among sectors it is lower. However, the differences between sector estimates are not statistically significant. In addition, since only 54 sectors were comparable this may explain the lower correlation.

This review and analysis build on the extensive field and research work undertaken by The International Centre for Environmental Management (ICEM) for the World Bank between September 2005 and January 2007. In addition, a partnership was formed to carry out the study comprising the Ministry of Industry (MOI), Ministry of Natural Resources and Environment (MONRE) and The World Bank. The focal points and Steering Committee members within each organization were $\mathrm{MOI}$ Department of Science and Technology, MONRE Department of Environment, and the World Bank's Vietnam environment program. The $\mathrm{MOI}$ Institute for Industry and Strategy was the implementing organization working with ICEM for both the logistical and technical aspects of the project.

A technical advisory group of representatives from relevant industrial and environmental management organizations was the main mechanism for technical participation and contributions to the research for this review. The advisory group comprised industry managers within government (MARD, MOI, MOC, MOT, and MOFI) along with Ministry of Natural Resources and Environment, a range of industry environmental specialists and institutes, and selected provincial representatives from the 3 economic growth triangles. The advisory group of some 30 members met 5 times at key stages to review analysis and findings and guide further work. A wider network of industry and environmental experts were involved through workshops and other forms of consultations, which took place throughout the field data collection and report drafting. One final consultation workshop to present key findings and options to implement some of the recommendations was held June 14, 2007 in Hanoi. During this event, two other analytical pieces - Poverty-Environment Nexus: Impacts from Industrial Pollution, and Future Industrial Development and Environmental Management in Vietnam were shared with counterparts in MONRE, MOI, and locallevel agencies to strengthen and complement this report. 


\section{Report structure}

This report comprises 5 sections. Section 1 provides an overview of the industrial sector in terms of recent and projected economic relevance and ownership structure. Section 2 presents the analysis of the pollution structure and impacts from the manufacturing sectors. The main features of the current institutional and regulatory framework their strengths and weaknesses are outlined in the Section 3. A review and analysis for environmental protection expenditure for the industrial sector in Section 4. Sections 5 and 6 identify areas where the Government could focus its efforts to raise the bar to in addressing some of the growing challenges derived from increasing pollution loads, concentrations, and toxicity from the manufacturing sectors. 


\section{SECTION 1. THE INDUSTRIAL SECTOR IN VIETNAM}

\subsection{Overview}

The process of economic policy reform (doi moi) began in 1986 and is a continuing central feature of Vietnam's national economy that has expanded rapidly and without pause for over 20 years. In the 1990s, GDP grew at an average annual rate of 7.5 percent, and reached 8.43 percent in 2005. However, different sectors of the economy have experienced significantly different growth rates. Between 1991 and 2000, the annual growth rate for the agriculture, forestry, and fishery sectors was around 4.2 percent; the industry and construction sectors averaged around 11.3 percent, and the services sector grew at a rate of 7.2 percent. Over the period 2001-2005, 'industry and construction' continued to grow faster than the 'services' and the 'agriculture, forestry and fisheries' sectors - with the latter contributing less than 10 percent to Vietnam's overall economic growth in 2005 (Table 1.2).

Between 1995 and 2005, Vietnam's economy experienced an important structural shift, which saw the relative contribution to the economy of agriculture, forestry, and fisheries fall from 27.2 percent to 20.5 percent, and the contribution of industry and construction rise from 28.8 percent to 41 percent (Table 1.2). This shift has been accompanied by significant changes in the structure of labor. In fact, while the agriculture, forestry, and fishery sector continue to employ the largest share of the labor force (24.9 million of 43.6 million workers in 2005), its proportion of workers has fallen from 71.1 percent in 1995 to 57 percent in 2005. The proportion of workers in the industry and construction sector increased from 11.4 percent to nearly 18 percent, and the proportion of workers in trade and services increased from 17.5 percent to 25 percent. ${ }^{16}$ All economic regions have experienced similar trends; this structural shift is particularly significant in the Red River Delta, the Southeast Region (including Ho Chi Minh City), and the Mekong River Delta. Industry and construction now accounts for approximately 60 percent of the Southeast Region's economic activity.
Table 1.2. Change in the Economic Structure

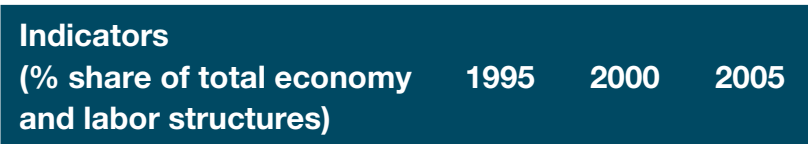

Economic structure

\begin{tabular}{|llll|}
\hline Agriculture, forestry and fisheries & 27.2 & 24.5 & 20.5 \\
\hline Industry, construction & 28.8 & 36.7 & 41.0 \\
\hline Services & 44.0 & 38.8 & 38.5
\end{tabular}

Labor structure

\begin{tabular}{llll}
\hline Agriculture, forestry and fisheries & 71.1 & 68.2 & 57.0 \\
\hline Industry, construction & 11.4 & 12.1 & 18.0 \\
\hline Services & 17.5 & 19.7 & 25.0
\end{tabular}

Source: SEDP, 2006-2010

\subsection{Ownership Structure and Geographical Distribution}

Between 2001 and 2005, some 3,183 state-owned enterprises (SOE) were restructured, including 2,056 equitized, and 181 liquidated or declared bankrupt. ${ }^{17}$ With the notable exception of Hanoi and Ho Chi Minh City, almost all provinces and localities have fulfilled their equitization plan. However, despite continuous efforts to reform state-owned enterprises, the state sector continues to play an important economic role, contributing to approximately 40 percent of Vietnam's GDP. The process of reforming state-owned enterprises remains difficult, has not proceeded as speedily as expected, and has involved mostly small-scale enterprises (with capital less than VND 5 billion) and only a few large enterprises. Also, equitization, renovation, and modernization have been especially difficult for line ministries (e.g., Ministry of Industry, the Ministry of Construction, and the Ministry of Agriculture and Rural Development) with a significant number

16. CIEM (2006), Vietnam's Economy in 2005.

17. Report of the Central Economic Committee on “The Implementation of the Central Party's Resolution No.3 and the Central Committee's Resolution No. 9 of the IX Term on SOE Restructuring, Renovation and Effectiveness Improvement”. 
of state-owned enterprises in large general corporations, which still find themselves owning and regulating many of the severest polluting enterprises throughout the country. Also, over the same period, approximately 170,000 enterprises of all sizes were registered with a total capital of VND 305,000 billion. In 2005 alone, it is estimated that 45,000 new enterprises were established with a total capital of over VND 110,000 billion; and private enterprises, including households and individual enterprises, generated 40 percent of the country's GDP and created 49 percent of non-agricultural jobs in rural areas.

The food products and beverage sector had in 2004 by far the largest number of enterprises, with 4,480, or 21.9 percent, out of 20,444 manufacturing firms in the country. The second most important sector - fabricated metal products - represents 10.4 percent of all enterprises. These two sectors have more than 32 percent of all manufacturing firms but only 18.2 percent of all manufacturing employment with relatively small facilities of 51 and 91 employees on average respectively. Three sectors - tanning and dressing of leather, wearing apparel and food products and beverages - together have close to 50 percent of all employment in the manufacturing sector. In particular, tanning and dressing of leather has 18.1 percent of all employment with only 2.5 percent of all firms. Firms in this sector tend to be much larger than firms in other manufacturing sectors. Vietnam's industrial activity is concentrated in a small number of industrial sectors. These vary in terms of the nature of ownership; non-metallic mineral products, and food products and beverages represent most of the industrial production value of enterprises owned by the central government. In particular, the food products and beverage sector represents 40.4 percent of all the value produced by locally owned state enterprises. This sector also represents the largest share of all industrial value produced by the domestic private (non-state) sector (29.8 percent) and foreign-invested sector (18.7 percent). The importance of this sector for each type of owner simply reflects its size - it represented 25 percent of all industrial production value in 2004.

The state sector and domestic non-state sector represent 37.6 percent and 37.8 percent, respectively, of the value of industrial production in the food product and beverage sector. The domestic private (non-state) sector represents the largest share of industrial production value, especially in the wood and wood products sector, the paper and paper products sector, the fabricated metal products and furniture sector. The domestic private sector also represents 100 percent of the value of industrial production in the recycling sector. On the other hand, the foreign-invested sector represents the largest share of industrial production value in the wearing apparel sector; leather tanning and dressing sector; and the machinery, equipment, and transport related sectors.

In 2005, foreign direct investment (FDI) accounted for 15 percent of GDP, a significant increase from 6.3 percent in 2001. Taiwan, the Republic of Korea, Japan, Singapore, China, and Hong Kong are the most significant foreign investors (in terms of number of projects) accounting for 70 percent of all FDI projects in Vietnam and 62 percent of all FDI capital investment. To date, 68 percent of all FDI projects $(4,290$ projects out of 6,341$)$ have been in the industry and construction sector. This significant growth of foreign direct investment has been accompanied by an increasing openness of Vietnam's economy. The value of exports increased at an annual rate of 16.2 percent over the period 2001-2005, made up of goods mainly from light and small-scale industry and the agriculture, forestry, and fisheries sector (40.2 percent and 27 percent, respectively). In 2005, 50 percent of exports were directed to the United States of America, various countries of the European Union and Japan. Box 1.1 provides more information about foreign direct investment. 


\section{Box 1.1. Industrial sector draws US\$2.1 billion in foreign direct investment}

Between 2005 and 2006, Vietnam attracted 464 industrial projects with total foreign capital of US\$2.1 billion, accounting for 58 percent of the country's total FDI, according to the Ministry of Planning and Investment (MPI). Most of the investment capital was in heavy industry with 194 projects worth US\$1.4 billion, an increase of US\$600 million compared with the entire year of 2004. Foreign investors also poured US\$610 million into 226 light industrial projects, chiefly in the food, beverage, and garment industries. MPI officials said average investment capital for each FDI project rose from US\$2.6 million per project in 2004 to US\$4.5 million in 2005.

Projects in heavy industry have attracted largescale projects worth hundreds of millions of dollars. They include a US\$700 million stainless steel project in the southern province of Ba Ria-Vung Tau, an auto-making project in the central coastal province of Phu Yen and a US\$48 million Yamaha auto parts plant in Thang Long Industrial Park in Hanoi. According to MPI officials, 25 percent of the total FDI this year has been pumped into factories in industrial parks and export processing zones. Officials said the high foreign investment in heavy industry has helped spur growth in supporting industries and created favorable conditions for Vietnam to integrate into the world economy. In 2005, the FDI sector posted a growth rate of 28.2 percent in industrial value, the highest growth in the last five years. The private domestic sector posted a 24.6 percent growth rate and the Staterun sector 8.9 percent.

Source: Authors
In 1976, there were 1,913 state-owned enterprises and jointstock companies in Vietnam, of which 66 percent $(1,279)$ were located in the North, and only 33 percent (634) in the South. Thirty years later, there were more than 90,000 enterprises, with approximately 45,000 located in the South (GSO, 2004). Vietnam divides its industrial sector into 3 broad categories: (a) mining and quarrying; (b) manufacturing; and (c) electricity, gas, and water supply. Over the period 19861990, the annual average growth rate of the entire industrial sector was 6.07 percent; it reached 13.67 percent over the period 1991-1995 and 13.57 percent over the period 19962000. The value of industrial output, measured in constant 1994 prices, grew 15.7 percent annually over the period 2000-2005 and reached VND 416,863 million in 2005, an increase of 17.2 percent over 2004. Industry now contributes more than 40 percent of GDP and represents 70 percent of total export revenues. The manufacturing sector (one of the three industry categories) grew at a rate of 16.7 percent annually over the period 2000-2005. It is the most important component of the industrial sector representing more than 83 percent of the total value of industrial output.

In 1997 the Government of Vietnam established 3 economic focal regions (EFR) to foster balanced economic growth and promote the comparative advantages of different geographic areas. The Northern Economic Focal Region, Central Economic Focal Region, and Southern Economic Focal Region (Figure 1.1) play a crucial role in the growth of the Vietnamese economy; initially, they included 5 provinces in the North and 4 provinces and cities in each of the Central and Southern Economic Focal Region. ${ }^{18}$ In 2004, the Government increased the number of provinces included in the economic focal regions from 13 to 20 .

While the 20 provinces (out of 64 nationwide) represent only 22.3 percent of Vietnam's land area, they include around 41.6 percent of its population. The Northern Economic Focal Region occupies only 4.6 percent of Vietnam's land area but includes 16.3 percent of its population. These 3 economic

18. The primary regulatory framework for the 3 economic focal regions was the adoption of Decision No.747/1997/QD-TTg (dated September 11, 1997) for the Northern Economic Focal Region; Decision 1018/1997/QD-TTg (dated September 29, 1997) for the Central Economic Focal Region; and Decision No. 747/1997/ QD-TIg (dated September 11, 1997) for the Southern Economic Focal Region. 
focal regions play a crucial role in Vietnam's economy. In 2004, the 3 economic focal regions accounted for 63.5 percent of total GDP and approximately 86 percent of total Vietnamese exports, 80 percent of all employment in the industrial sector, and 71.4 percent of all firms. The Southern Economic Focal Region is the more important among the economic focal regions: it contributes over 40 percent to Vietnam's GDP and 70 percent of total exports; it also accounts for 68.4 percent of the total EFR employment and 58.5 percent of the all the firms located within the 3 economic focal regions.

\subsection{Industrial Estates}

The establishment of industrial estates in Vietnam is an important factor contributing to the rapid industrialization of the country. Investors register in industrial zones to benefit from various types of tax exemptions; subsidies; and access to infrastructure, such as road, electricity and water supply, storage houses, and other facilities, including wastewater treatment facilities. Such preferential investment incentives, complemented with a 'onedoor' policy with industrial zone management boards have contributed to the rapid increase of domestic and foreign investments within industrial estates. Local governments in some localities (such as Hanoi, Hai Phong, Ho Chi Minh City, Binh Duong, and Dong Nai) provide strong support to the development of industrial estates, competing with one another to attract investment and to fill the space in the industrial estates under their management (see Box 1.2).

Industrial estates in Vietnam are generally classified into two types: industrial zones and export processing zones. By May 2005, Vietnam had 71 industrial estates of which three were export processing zones. These estates were spread out over 30 provinces. Existing industrial estates in Vietnam include 3,351 firms, 50 percent foreign-owned and employing some 640,000 persons. These firms comprise 16 percent of all industrial facilities in the country and employ 22 percent of industrial workers. Between 2000 and 2005, industrial estates increased their share of total industrial production value from 13.7 percent to 26.4 percent, and continue to expand rapidly.

An additional 52 industrial estates are under construction; 15 will be developed in four Southern provinces. Most industrial estates are located within the economic focal regions. ${ }^{19}$ The provinces of Dong Nai, Ba Ria-Vung Tau, Binh Duong, and Ho Chi Minh City have established 38 industrial estates with 2,142 enterprises employing 432,000 persons. These estates hold 27 percent of all industrial facilities and 30 percent of all industrial employment in those provinces. A significant and increasing share of the industrial activity in Southern Vietnam takes place within industrial estates.

19. The GSO Business Survey does not request enterprises to indicate if they are located within or outside an industrial estate. As a result, no information can be extracted from the GSO 2004 database specifically for firms located within industrial estates. This significantly limits the potential descriptive analysis of industrial estates. This information should be requested in future surveys. 


\section{Box 1.2. 2005 A Record Year for Hanoi Industrial Estates}

The Hanoi Industrial and Export Processing Zone (IEPZ) Management Board said 2005 was a record year for both new investment projects and export turnover in the capital. The Board said the total export value of companies in the city's industrial zones reached US\$834 million in 2005, representing a yearon-year growth rate of a staggering 63 percent.

Hanoi has 4 major industrial and export processing zones: Sai Dong B, Thang Long, Noi Bai, and the Hanoi-Taiwan Industrial Zone. The city also has 8 smaller industrial complexes, including Vinh Tuy, Phu Thuy, Tu Liem, and Dong Anh. The larger zones in 2005 attracted 19 new projects - almost twice as many as in the previous year - with total registered capital of US\$152 million, said the Board's deputy director, Nguyen Van Viet. He said several companies already operating in the zones filed applications to the Board to raise investment capital levels by a combined total of US $\$ 153$ million, a yearon-year increase of 25 percent. Enterprises in Hanoi's Industrial and Export Processing Zone posted revenue growth of 48 percent to US\$1.2 billion, and paid around US\$25 million in taxes (Vietnam News, January 20, 2006).

The provinces of Dong Nai, Ba Ria-Vung Tau, Binh Duong, and Ho Chi Minh City have established 38 industrial estates with 2,142 enterprises employing 432,000 persons. These estates hold 27 percent of all industrial facilities and 30 percent of all industrial employment in those provinces. A significant and increasing share of the industrial activity in Southern Vietnam takes place within industrial estates.

Source: Authors

\subsection{Handicraft Villages}

Many industrial goods are produced by handicraft villages ranging from hand-crafted items; arts; and embroidery; to food and beverages; silk; cloth and tanning products; construction materials; and recycling of paper, plastic, glass and metal. ${ }^{20}$ The Government considers handicraft villages as part of an important strategy for promoting rural economic development, increasing household income, and improving living standards in rural areas where 75 percent of Vietnam's population still reside. ${ }^{21}$ There are 1,450 handicraft villages throughout the country, providing for more than 10 million jobs, or 29 percent of the rural workforce. While handicraft villages are found in most provinces, they are concentrated in the North with approximately 70 percent located in the Red River Delta economic region.

In a recent study (JICA, 2005), 2,017 handicraft villages were identified. However, in this study handicraft villages were defined as having at least 20 percent of households involved in the same craft or at least 20 percent of the village's income originating from handicraft products. Villages in those categories have 1.4 million households and 11 million people (MARD, 2005). ${ }^{22}$ In the JICA study, 63 percent of the villages were located in the North. A significant proportion of the villages were making bamboo and rattan products (35 percent), embroidering and textiles (38 percent), and wood products (17 percent). The number of enterprises in craft villages is estimated to be 40,500 , around 80 percent being family businesses with 1 to 3 employees. In 2000, the production value of handicraft village activities reached VND 40,000 billion. Total export value from handicraft villages reached US\$562 million. The main export products included ceramics, artisan handicrafts, bamboo and rattan, silk, embroidery, and wood products. Average income per capita in craft villages is up to 5 times higher than in villages devoted mostly or exclusively to agriculture.

20. The annual production value and income from non-farming crafts covers more than 50 percent of total annual production value and income of the whole village, or the annual turnover from crafts is at least VND300 million; or the number of households and workers engaged permanently or temporarily, directly or indirectly in the non-farming crafts makes at least 30 percent of the total number of households and workers in the village, or there are at least 300 workers involved in the crafts. 21. Korea Environment Institute Report (2003), Vietnam Regional Environmental Management for Traditional Villages.

22. Draft proposal of the program "each village each handicraft", MARD, 2006. 
Vietnam has given high priority to rural and decentralized development, and handicraft villages in particular as a means to achieve its policy of rural industrialization. Pursuant to Decision 132/QD-TTg, handicraft villages are encouraged to diversify their production and adopt advanced technology combined with traditional skills. The National Congress issued Resolution $14 / N Q-T W$ that aims to facilite and encourage the development of private sector, especially in handicraft villages. Also, the Government is attempting to create favorable conditions for the development of export industries, agro-product processing, and traditional craft products. Specific support provisions include:

- Land policy. In general, the land law and policy has facilitated organizations, households, and individuals to lease land on a long-term basis. Leaseholders have five rights in relation to land management: decisions, use, transfer, inheritance, or lease. Decision 132/2000/QD$\Pi \mathrm{Tg}$ provides that rural craft businesses will be given priority to lease land at the minimum price;

- Investment policy. The investment policy on economic activities of craft villages pertains to the development of infrastructure or support to the development of local enterprises and rural career development through credit and financial tools. In general, the Government's investment policy for handicraft villages attempts to create a more open environment for the development of industrial zones in rural areas or to create synergy across handicraft villages;

- Credit policy. To facilitate and support the development of handicraft villages, the Government has issued preferential credit policies with various forms of subsidized loans (for example, Decision 193/2001/QD-TTg offers credit guarantees for small and medium enterprises). Approximately 33 percent of rural households can now access credit sources from financial organiations;

- Tax policy. With the Value-Added Tax Law, under Decision 132/2000/Q-TTg and other legal documents, the tax policy provides prioritized tax support for the development of careers and handicraft villages. Basically, the tax policy encourages and supports the trading and development of handicraft villages.

\subsection{Industrial Sector Expected Growth}

The Socio-Economic Development Plan (SEDP) sets out the industrial development expectations and objectives for the period 2006-2010 with a vision toward 2020; Vietnam is expected to reach industrialized nation status by 2020. This section summarizes key elements of the plan. By 2020, the proportion of industry and construction in GDP should reach approximately 45 percent from the existing 42 percent. ${ }^{23}$ For this to be achieved, industrial production value should continue to grow 15-16 percent annually. If this objective is achieved, per capita income should reach between US\$730 and 800 in 2010 and between US\$1,600 and 1,800 in 2020. The overall objective of the SEDP 2006-2010 is to consolidate the industrialization of Vietnam as a means of increasing GDP per capita and reducing poverty incidence. Specific sector targets, as they appear in the SEDP 20062010, include:

- Steel. Steel demand in 2010 is forecasted to reach 12 million tons, with an average annual rate of increase of 7.5 to 8 percent. To ensure balance with demand, domestic steel production is expected to reach 9 million tons and pre-engineered steel to reach 4 million tons in 2010.

- Cement. Annual cement production should increase 15 percent annually to reach 50 million tons by 2010 , from the existing 32 million tons.

- Paper. Investment in numerous paper and pulp projects is expected to substitute for pulp import; 1.2 million tons of cardboard and wrapping paper of all kinds will be produced in 2010.

- Fertilizers and chemicals. The objective is to ensure self-sufficiency of fertilizers for agricultural production. It is estimated that 70 to 75 percent of the domestic demand for urea as well as 100 percent of phosphate, and fertilizers will be satisfied through domestic production by $2010 .{ }^{24}$

23. MOI, Strategy on development of industry Vietnam to 2015 with the vision of 2020. Hanoi.

24. To achieve this objective, the Government aims to complete and put in operation the Ninh Binh project by 2008. This project will produce 560,000 tons of nitrogen fertilizers from coal powder. The Government also aims to initiate and complete the Ca Mau fertilizer plant and the DAP fertilizer plant with a production capacity of 800,000 and 330,000 tons per year, respectively. 
- Textile and garments. The objective is to produce 1,100 million square-meters of silk of all types and 1,500 million garment items; and reach an export turnover of US\$10 billion in 2010. To achieve that objective, there needs to be a fundamental shift in product structure, a significant increase of products with high added value, and an increase in the domestic content of exported goods.

- Footwear. The focus is on modernizing footwear and leather production, developing leather sources of all types, and increasingly using local materials to improve the value added of export products. The next five years will see more investment in improving quality and production with the introduction of application software into design, sewing, etc.; diversifying products and designs; and transforming from partial to complete production line.

n Plastics. The aim is to satisfy the domestic demand for plastic packages and accessories and to link material input production for the plastics industry with petrochemical industry.

- Beer, liquor, and beverages. Priority will be given to increasing the production capacity of beverages from fruits and mineral water and to expand existing beer breweries to increase capacity to 2.5 billion liters in 2010 .

- Machinery. The overall objective is an annual growth rate of 18 to 20 percent. This is expected to be achieved by (a) concentrating on products with market competitiveness, particularly those serving agriculture and rural areas, such as small motors, water pumps, tractors, farming machines, agricultural and fishery processing equipment; (b) developing machinery for construction equipment, shipbuilding, automobiles and motorbikes; (c) undertaking research, design, and manufacture of equipment and spare parts for the cement, paper, electricity, fertilizers, chemicals industries, gradually substituting imports; and (d) satisfying 35 percent of the country's demand for heavy machinery.

Some of these priority industrial sectors and subsectors are among the most polluting sectors in the country. Inevitably, this expansion will lead to significant increases in industrial pollution unless the added capacity in these sectors follows cleaner production approaches including less pollution intensive technology.

\section{Economic Focal Regions}

All regions of the country aim to expand the industry and construction sector and anticipate reductions in the agriculture, forestry, and fisheries sector. The Northern economic focal region aims to achieve an average annual economic growth rate of 11 percent and in doing so to contribute 20 percent to national GDP by 2010 (from the existing 18 percent) with a rapid restructuring of its economy toward industrialization. Industry should grow at an annual rate of 16 percent over the period 2006-2010. By 2010, industry should represent 45 percent of the total economy of the region (from 41 percent in 2004), and services at 50 percent (from 45 percent in 2004). Within the industrial sector, priority is given to knowledge intensive products (such as software), products of electric and electronic engineering, equipment and machinery, steel and shipbuilding, coal, cement, high-quality construction materials, food processing, textile and garment, and leather industries. The rate of urbanization is expected to increase from the existing 31 percent to 52 percent in 2010, and 65 percent in 2020.

The Central economic focal region aims to achieve an annual industrial growth rate of 18 percent, and increase per capita GDP from the existing US\$400 to US\$1,337 by 2010. In 2010, the industry and construction sector should represent 41 percent of the economy (a significant increase from 34 percent in 2004); the services sector should represent 46 percent of the economy (from 39 percent in 2004); and the agriculture, forestry and fisheries sector, 13 percent (a significant reduction from the 27 percent in 2004). Within the industry and construction sector, priority is given to construction of economic zones (such as Chu Lai Open Economic Zones, Dzung Quat Economic Zones, Chan May Economic and Commercial Zones, and Nhon Hoi Economic Zones in 2010); the completion and effective exploitation of 9 industrial and manufacturing zones in the region; and the development of an oil refinery, as well as petro-chemical and chemical industries.

Aiming at the development of the region's industrial sectors, the southern provinces of Dong Nai, Binh Duong, Ba RiaVung Tau, Binh Phuoc, Binh Thuan, Tay Ninh, and Lam Dong, as well as Ho Chi Minh City, have issued resolutions to enhance co-operation and classify industrial production areas 
across the region, said provincial authorities. The resolution of the southern provinces concentrates on developing key industrial sectors, including oil and gas exploitation, electrical production, fertilizer, information technology, machinery, agricultural and forestry products processing, and food processing. The provinces will strengthen industrial processing zones and restrict the construction of labor-intensive factories in urban areas.

To avoid unequal and overlapping development between the provinces in the region, each province will focus on development of key sectors. Ho Chi Minh City will prioritize such sectors as machinery, metal working, electronics, information technology, and chemicals. Ba Ria-Vung Tau will focus on oil exploitation and processing, steel rolling and refining, and energy and construction materials production. Dong Nai Province will promote agricultural products processing, minerals exploitation, textiles, footwear, and support services for industry. The Southern provinces have targeted an annual average industrial growth rate of 17.5 percent by 2010. The provinces' industrial production value regularly accounts for 50 percent of the country's total. In 2005, the region's export turnover also accounted for over 80 percent of the nation's total exports. The Prime Minister recently issued a decision for an action plan for socioeconomic development of the southern key economic region through 2010, along with orientations for 2020. Under the plan, the region's GDP in 2010 would be at least 2.5 times that of 2000, and by 2020 2.3-2.5 times that of 2010. Export value should increase at twice the rate of GDP growth.

\section{Industrial Estates}

The development of industrial estates is a key policy in Vietnam's industrialization process. ${ }^{25}$ The Ministry of Planning and Investment (MPI) has developed a strategic plan for the development of the estates over the period 2006-2010, with a vision to the year 2020. ${ }^{26}$ According to this strategic plan, by 2010 industrial estates will attract 2,450 new investment projects and 2.5 million additional workers - an annual average growth rate of over 20 percent. The value of industrial output from firms located within industrial estates is expected to increase at 17.7 percent annually over the period 20062010 and reach US\$30 billion in 2010. Firms located within industrial estates are expected to increase their contribution to total industrial production value from the existing 26 percent to 35 percent in 2010, and increase their proportion of the total value of Vietnamese industrial exports from the existing 19 percent to 32 percent by 2010 .

\section{Handicraft Villages}

The Ministry of Agriculture and Rural Development has finalized its master plan to 2010 for handicraft villages. It calls for an annual growth of 15 percent for the period 2006-2010, and a 20 percent annual increase in export revenues. The Ministry also aims to create some 300,000 new jobs each year, focusing on labor-intensive and market-demand industries, such as handicrafts, food processing, and smallscale engineering. Development targets are based on the potential of each geographic region. For high-skilled craftmaking, such as lacquering, the wood industry and embroidery are given priority in the Red River Delta. The central coastal region will tap its potential in stone quarries, wood, and porcelain products. The Central Highlands will focus on traditional crafts of ethnic minority groups, and the alluvial Mekong Delta will develop its farm produce, aquatic product, and seafood processing industries together with intensive investment in porcelain products.

\subsection{Global Integration and the Development of Vietnam's Industrial Sector}

Trade liberalization and export promotion have been central to Vietnam's continuing economic transition and rapid industrialization. Vietnam has pursued a multi-pronged approach to gradually reducing trade barriers and increasing

25. In Vietnam, the term industrial cluster is generally used to define an informal clustering or high concentration of industrial facilities within a limited geographical
area. The terms industrial estate, industrial zone and industrial park are variously used by government and the international community to refer to special areas
set aside for establishment and servicing of industrial plants. These areas have management boards and are usually walled off from surrounding land uses. 26. MPI (2005), "Orientation for developing industrial zones in Vietnam to 2020 - Objectives and implementing development plan for the period 2006-2010" 
the outward orientation of the economy. The Government's commitment to trade liberalization has been fueled to a large extent by bilateral and multilateral trade agreements. Under the ASEAN Free Trade Agreement (AFTA, 1995), tariffs on imports from ASEAN countries were reduced to below 20 percent and are targeted to be below 5 percent by 2006. Under the United States-Vietnam Bilateral Trade Agreement (USBTA, 2001), Vietnam made substantial further commitments to liberalize its trade regime, including tariff reduction and removal of quota restrictions. Other trade reforms under the USBTA to which Vietnam has committed include improving transparency in its trade laws, introducing dispute settlement procedures, protecting intellectual property, and facilitating investment. The USBTA has provided a sizable stimulus to exports, with exports to the United States increasing by 128 percent and making up 82 percent of total export growth in 2002. The United States is now Vietnam's largest exports market (IMF, 2003). The composition of Vietnam's exports and imports has also changed significantly during this period. While the share of crude oil in total exports declined from one-third in the early 1990s to one-fifth by 2002, manufacturing exports rose from 6 percent to 32 percent. There has been a significant diversification in Vietnam's export markets as well. With Vietnam becoming less dependent on oil exports, Japan and Singapore have become less important export markets. The European Union and United States have become major markets for manufactured goods, such as textiles, garments, and footwear.

Significant developments are expected following Vietnam's accession to the WTO. ${ }^{27}$ In general, the average tariff rate on the import of manufactured goods into Vietnam will be reduced from approximately 18 percent to 12.5 percent, making the export of manufactured goods to Vietnam more competitive. In addition, a large number of subsidies and tax incentives provided by the Government of Vietnam to the industrial sector are prohibited by the WTO and will have to be phased out. ${ }^{28}$ Most existing import bans introduced by the Government will have to be eliminated. While Vietnam will benefit from a greater access to world markets, its industrial sector will face a much greater level of competition, as indicated in particular by the following:

- Chemicals, cosmetics and pharmaceuticals. Vietnam has committed to reduce tariffs to the harmonization rates by the Chemical Harmonization Agreement on 80 percent of chemical products. Vietnam's average tariff on cosmetics, a subsector in chemicals, will be reduced from 44 percent to 17.9 percent upon full implementation. Pharmaceutical tariffs will average 2.5 percent within 5 years after accession.

- Motor vehicle parts. Tariffs on auto parts will be reduced by 19 percent to an average of 13 percent. Vietnam will also reduce its tariff on large motorcycles by 56 percent and motorcycle parts by 32 percent after full implementation.

- Agriculture and construction equipment. Vietnam will reduce tariffs to 5 percent or less for close to 90 percent of its tariff lines.

- Wood products. Vietnam's average tariff on wood products will be approximately 4 percent upon accession.

- Textile and garment. Removal of export quotas for Vietnamese exports of textile and garments. Removal of US\$4 billion subsidies provided by the Vietnamese Government to the textile and garment sector within the next five years. Levies against imported garments and textiles are to be lowered to 10-15 percent from current 40-50 percent.

- Ferrous and other scrap metals. Vietnam will reduce export duties on such metals by up to 51 percent of current levels over the next 5-7 years.

27. Accession approved by the WTO General Council on November 7, 2006. For more details, see Trade Facts, May 31, 2006 (published by the Office of the United States Trade Representative, Executive Office of the President of the Unites States).

28. For example, Decree 164 on the implementation of the Law on Enterprise Income Tax provides that a company having an export sales volume of more than 50 percent of the total value of goods produced qualifies for a 20 percent tax rate for 10 years from the commencement of business operation, a two-year tax exemption, and a subsequent 3-year 50 percent tax reduction from the first profitmaking year. Companies exporting 100 percent of their production enjoys a 10 percent tax rate for 15 years from the commencement of business operation, a four-year tax exemption and a subsequent seven-year 50 percent tax reduction. Such tax incentives are expected to be in violation of the WTO Agreement on Subsidies and Countervailing Measures. Vietnam's Ministry of Finance recognizes that exports subsidies of this nature will have to be gradually reduced as Vietnam joins WTO. 
- Information technology products: Upon WTO accession, Vietnam will join the Information Technology Agreement, which eliminates tariffs on information technology products including computers and cell phones;

Vietnam's accession to the WTO will also impact the agricultural and service sectors. The current average tariff applied on agricultural products is 27 percent. Upon accession, tariffs on more than three-fourths of US agricultural exports to Vietnam will be limited to a rate of 15 percent or less thus making exports of agricultural products to Vietnam considerably more competitive.

Vietnam's accession to the WTO is thus expected to have great influence on its foreign trade in terms of volume and structure as it requires a commitment to simplify import controls, reduce the level of import protection, and reduce or eliminate various forms of industrial and agricultural support and export subsidies. With WTO membership, Vietnam will participate in the global re-allocation of inputs productivity, such as land, labor, capital, and natural resources. This will induce a restructuring of Vietnam's overall economy, including its industrial structure. In particular, Vietnam may significantly increase its exports, which may in turn lead to a rapid expansion of exportoriented sectors. However, based on Vietnam's known comparative advantages, the following changes may be expected in the short to medium term:

- Labor intensive industrial sectors such as handicraft as well as textiles and garments may further expand (relative to a scenario where Vietnam would not access WTO). However, Vietnam's comparative advantage in such sectors (especially the textile and garment sector) may be offset by the removal of various subsidies currently supporting them. Firms heavily dependent on subsidies will need to rationalize their operations to benefit from Vietnam's accession to WTO. In all likelihood, some will not be capable of doing so.
- Land intensive industries, such as plantation, grain production and traditional husbandry, would decrease. This is particularly the case since Vietnam's explicit policy is to industrialize its rural sector.

- Capital intensive industries and services would increase significantly, including banking, security, insurance, brokerage, tourism, real estate, and education.

Changes to the nature and path of industrialization are expected to take place gradually over a relatively long period of time. In most cases, with the possible exception of the textile and garment sector, import duties and export subsidies are being reduced over a period of 5 to 10 years rather than being eliminated. Also, as member of the ASEAN Free Trade Agreement and signatory of USBTA, Vietnam has to a limited extent already embarked on some reforms to its import and export tariff and non-tariff system. With WTO accession, Vietnam will consolidate those revisions. This is not to understate the scale and importance of the challenges ahead.

As noted in the SEDP 2006-2010, despite recent achievements, Vietnam's capacity to respond to the challenges of increasing integration in the world economy suffers from significant constraints. The overall competitiveness of Vietnam's industrial sector is limited and weak, and is currently characterized by low productivity, low and outdated technological standards, and high production costs. ${ }^{29}$ The operational effectiveness of state-owned enterprises is low. Despite (or because of) this low productivity, state-owned enterprises, especially large state corporations, continue to benefit from privileged access to land use, capital, and various forms of tax exemptions and subsidies. The SOE reform process has been slow and mainly implemented in enterprises with small capital. Large corporations owning hundreds of enterprises have remained in the hands of the state. Despite its dynamism and increasing importance in the economy, the non-state sector is currently made up of small and medium

29. According to assessment and comparison of the latest data of 2004-2005, Vietnam's business competitiveness index ranks $79^{\text {th }}$ among 103 , Vietnam's national general competitiveness index $(\mathrm{GCl})$ in global comparison ranks $77^{\text {th }}$ among 104; economic development is still at a low level. Even in information technology, which records the highest acceleration in Vietnam, still ranks at 68th among 102 countries. The comparative corruption index published by the Transparency International, reflects the seriousness of this issue in Vietnam, which ranks $102^{\text {nd }}$ among 144 countries in the world. In terms of business operation and strategies as well as national business environment, Vietnam is behind other countries in the region like China, the Philippines, Indonesia, Malaysia, and Thailand; and well behind South Korea and Singapore. 
enterprises with limited access to capital to undertake investments in new technology. Finally, the structure of labor supply is not suitable for a technologically advanced industrial sector as Vietnam is still characterized by a large pool of untrained labor and an inadequate supply of skilled workers.

\subsection{Summary}

Vietnam is experiencing a rapid urbanization and concentration of both its population and economic activity in a very limited number of geographical areas. In particular, the Southern Economic Focal Region is experiencing very rapid urbanization and industrialization. This region alone contributes to approximately 55 percent of Vietnam's industrial production. At this same time Vietnam is experiencing a fundamental structural shift of its economy away from the agricultural, forestry, and fisheries sector toward industry, and to a lesser extent toward services. This trend is expected to continue to develop and intensify with Vietnam's increasing integration in the global economy. Finally, the share of the domestic non-state sector as well as foreign-invested sector in the economy is rapidly increasing and is particularly higher in the Southern Economic Focal Region than in both the Northern and Central Economic Regions. This last development reflects an important and steady shift of the Government's role, responsibility, and function away from being an owner of the economy toward being a facilitator and regulator. If sustained, this shift will have important implications for environmental management in the industrial sector.

Vietnam is pursuing a policy of rapid industrialization, including the rural sector, as a means of achieving economic and social objectives. In this scheme, the development of the manufacturing sectors is of particular importance, particularly in its contribution to the country's industrial pollution profile.

First, the food products and beverage, wearing apparel, leather tanning and dressing, wood and wood products, fabricated metal products, and furniture are the most economically significant industrial sectors, representing 65 percent of all industrial employment and 57 percent of all industrial firms in the country.

Second, in terms of geographical distribution, most of Vietnam's industrial activity is located in five provinces/cities - Ho Chi Minh City, Binh Duong, and Dong Nai in the South; and Hanoi and Hai Phong in the North. Around 63 percent of all manufacturing employment and 54.7 percent of all industrial firms in the country are located in those 5 provinces. To a much smaller extent, Da Nang is the most important industrialized area in Central Vietnam.

Third, more than 80 percent of industrial activity is taking place within the 3 economic focal regions. The Northern Economic Focal Region and the Southern Economic Focal Region will intensify the existing process of urbanization and industrialization. The Central Economic Focal Region is expected to experience a significant shift of its development away from the agriculture, forestry, and fisheries sector toward an industrialization of its economic activities especially with the development of an oil refinery and associated petrochemical and chemical industries.

Fourth, even though the occupancy rate remains relatively low, industrial estates represent a growing economic and industrial contribution to Vietnam's economy and exports. An additional 4,000 new industrial facilities are expected to be located within existing industrial estates and estates under construction. It is expected that 35 percent of all manufacturing enterprises will be located within industrial estates by 2010. Most of these industrial estates are located in Southern Vietnam.

Fifth, handicraft villages areakey tool to achieving industrialization of the rural sector and increased rural income. Through a series of support policies, handicraft villages are expected to continue experiencing a rapid growth as a mechanism to achieve the policy of the government to industrialize the rural sector. Most craft villages are located in Northern Vietnam.

Finally, Vietnam's expected accession to the WTO will further consolidate its path toward industrialization and the increasing significance of the industry and service sectors at the expense of agriculture. The gradual removal of import control and duties, as well as export control and subsidies will lead to a steady re-allocation of resources (land, labor, and capital) toward those sectors in which Vietnam possesses comparative advantages at the regional and international levels. Superimposed on these trends, there may be abrupt changes that could have serious consequences at the local level, such as the closure of industrial facilities that find themselves unable to successfully compete on the regional and world stage. 


\section{SECTION 2. REVIEW OF THE POLLUTION STRUCTURE AND IMPACTS}

Industry in Vietnam has been growing very rapidly over the past decade and is likely to continue to do so over the next ten years. In 2005 the private industrial sector grew by more than 20 percent with the state-owned sector growing by close to 9 percent. Overall production for iron and steel, cement, textiles, and ceramics is growing at between 16 and 32 percent per year. Most industry is highly concentrated in a few areas of the country, which creates both problems and opportunities for environmental management. The growth of industrial estates and handicraft villages is creating new and significant small decentralized nodes of production and pollution densities.

In spite of the technological innovation happening in newly established factories, the greater proportion of plants operating now will continue to do so over the next five years with little or no innovation. Also, given current levels of uptake, only a relatively small part of the 15 percent annual growth in industry over the next five years is likely to be consistently clean, which means that continued increases in the total pollution load can be expected. In addition, the number and quantity of toxic chemicals and metals in pollution is also expected to increase rapidly as manufacturing processes diversify and grow in volume. This anticipated trend presents major management problems for industry and government; preventative measures should be set in place because of the high cost of monitoring and clean up. To date, the management responses are leading to important successes on a case-bycase basis but not to the extent that overall industrial pollution levels are decreasing. Also, it is likely that it would take at least five years before technological and management innovations really begin to have a significant impact on overall national pollution levels. So, under current regimes of investment and resource allocation, the situation will become much more serious before it begins to get better. More important, from a management point of view, it is not expected that the ranking of industrial sectors according to pollution releases will change dramatically over the next decade.

\subsection{The Industry Pollution Projection System}

The pollution estimates presented in the report result from the application of the Industry Pollution Projection System (IPPS). This model (described in the Introduction and in detail in Annex A) combines data on pollution information emissions to calculate pollution intensity factors (or coefficients) per unit of industrial activity.

The results of the initial analysis should be seen as a demonstration of methods for future application and to provide a broad systematic framework of priorities for action to address industrial pollution in a more systematic way. This section uses an aggregation and ranking methodology to identify priorities among sectors from national level to local levels. The ranking follows highest to lowest pollution loads for air, water, and land; and then according to an overall aggregate pollution index.

The pollution assessment also uses an overlay method so that geographic pollution concentrations can be interpreted against demographic, economic, and natural system information. The overall approach used for this report shows how estimates can be used to draw a complete picture of pollution types, sources, and location. It is an essential tool for environment and industry regulators in setting priorities and applying limited resources to managing the most serious pollution problems. Finally, throughout this report, when analyzing the IPPS results, the notion of high to low pollution load is used rather than worst to least polluters or polluted. A pollution load suggests that a sector/plant produces or an area receives a specified amount of pollution of certain types. The IPPS-estimated load serves as a first-order approximation of the overall pollution situation using the most comprehensive, industry-related database available. But the more focused the estimates on specific plants or local areas, the more important it is to validate through field survey whether or not the estimated load approximates the actual load being released to the environment. In some cases a specific plant or commune may be doing an excellent job in controlling and reducing pollution loads. 


\subsection{Pollution Load Indexes}

The use of an index creates economies of scale in prioritization. If a particular sector is pollution intensive across several pollutants of interest, efforts directed toward these sectors could address several pollution issues at the same time. In the report individual air, land, and water indexes, as well as a National Pollution Index are created for Vietnam:

- Air index is calculated as the simple average of $\mathrm{SO}_{2}$, $\mathrm{NO}_{2}, \mathrm{VOC}, \mathrm{PM}_{10}$, TSP, chemicals and metals to air loads; each air pollutant is given equal weight.

- Land index is the average of two categories of pollutants covered by the IPPS - chemicals toxic to land and metals toxic to land.

- Water index is the average of the four categories covered in IPPS - chemicals toxic to water, metals toxic to water, BOD, and TSS loads.

- An overall pollution load index is derived from an average of the three indexes.

Once each index is calculated, it is then sorted in descending order beginning with the highest pollution loadings on top; the list is then divided into four equal blocks representing the first, second, third, and fourth quartiles. Following the ranking exercise using the air, land, water, and overall pollution load indexes, a sector analysis is presented for each of the individual pollutants that make up each index to add some flexibility in the analysis. In addition, an analysis of toxicity and hazard at the sector level is also presented.

Table 2.1 presents the ranking of the top 30 industry sectors with the highest pollution loads (32 of 129 VSIC-4 categories) and provides an aggregate National Pollution Index for industrial sectors made up of separate indexes for air, water, and land pollution. These top ranking manufacturing industry categories need to receive the highest priority attention in the national pollution management plan. They play a critical role in the national economy since the manufacturing sector contributes 66 percent of total employment and 52 percent of revenue through 9,413 plants. The top polluters include 644 state-owned (9 percent), 1,040 foreign-owned (11 percent); and 7,209 privately owned (80 percent) enterprises. The manufacture of chemicals is of primary concern for air, land, and water pollution. The subsectors include plants involved in the production of fertilizers, pesticides, pharmaceuticals, and many industrial chemicals. The next most significant contributor to industrial pollution is the primary metals group that include plants involved in the processing and shaping, treating or coating of metals; and in mechanical engineering. Even the recycling of metal wastes appears in the top 30 for pollution load. 


\section{Table 2.1. National Pollution Index Ranking for Top 30 Sectors}

\begin{tabular}{|c|c|c|c|c|}
\hline Rank Industry sector (VSIC-4) & Air & Land & Water & Index \\
\hline 1. Fertilizers and nitrogen compounds & 11 & 3 & 4 & 6 \\
\hline 2. Footwear & 7 & 4 & 11 & 7 \\
\hline 3. Basic iron and steel & 11 & 4 & 13 & 9 \\
\hline 4. Basic chemicals (except fertilizers and nitrogen compounds) & 16 & 7 & 9 & 11 \\
\hline 5. Processing and preserving of fish and fish products & 10 & 7 & 17 & 11 \\
\hline 6. Plastics products & 17 & 7 & 12 & 12 \\
\hline 7. Pulp, paper and paperboard & 11 & 30 & 5 & 15 \\
\hline 8. Casting of non-ferrous metals & 26 & 5 & 15 & 15 \\
\hline 9. Other chemical products n.e.c. & 26 & 13 & 15 & 18 \\
\hline 10. Forging, pressing, stamping and roll-forming of metal; powder metallurgy & 28 & 11 & 15 & 18 \\
\hline 11. Other rubber products & 24 & 12 & 20 & 19 \\
\hline 12. Corrugated paper and paperboard, containers of paper and paperboard & 18 & 39 & 3 & 20 \\
\hline 13. Preparation and spinning of textile fibers; weaving of textiles & 20 & 22 & 22 & 21 \\
\hline 14. Veneer sheets; plywood, lamin board, particle board, other panels and boards & 18 & 40 & 6 & 21 \\
\hline 15. Casting of iron and steel & 30 & 13 & 23 & 22 \\
\hline 16. Treatment and coating of metals; general mechanical engineering & 35 & 16 & 19 & 24 \\
\hline 17. Structural non-refractory clay and ceramic products & 8 & 14 & 54 & 25 \\
\hline 18. Other manufacturing n.e.c. & 18 & 28 & 34 & 27 \\
\hline 19. Pesticides and other agro-chemical products & 42 & 16 & 28 & 29 \\
\hline 20. Furniture & 29 & 24 & 34 & 29 \\
\hline 21. Other fabricated metal products n.e.c. & 43 & 24 & 28 & 32 \\
\hline 22. Cement, lime and plaster & 20 & 34 & 45 & 33 \\
\hline 23. Pharmaceuticals, medicinal chemicals and botanical products & 43 & 29 & 29 & 34 \\
\hline 24. Vegetable and animal oils and fats & 27 & 37 & 39 & 34 \\
\hline 25. Soap and detergents, cleaning and polishing preparations, perfumes and toilet & 32 & 41 & 30 & 34 \\
\hline 26. Other electrical equipment n.e.c. & 33 & 30 & 45 & 36 \\
\hline 27. Recycling of metal waste and scrap & 51 & 27 & 30 & 36 \\
\hline 28. Basic precious and non-ferrous metals & 48 & 25 & 37 & 36 \\
\hline 29. Wearing apparel (except fur apparel) & 42 & 12 & 55 & 36 \\
\hline 30. Other non-metallic mineral products n.e.c. & 30 & 65 & 17 & 37 \\
\hline 31. Production, processing and preserving of meat and meat products & 33 & 46 & 36 & 38 \\
\hline 32. Refined petroleum products & 36 & 48 & 37 & 40 \\
\hline
\end{tabular}

Note: The first quartile has no colored box (white/light green) and the second quartile is colored dark blue. Source: Authors 
Seafood processing stands out within the food processing industries as of special concern in Vietnam. It includes cold storing; freezing; drying; smoking; and canning of fish, shrimp, squid, shellfish, algae, and other marine products. It also takes in the production of fish oil and sauces, seasoning products, and fish meal. This category of industry stands out prominently for the sheet scale of production and pollution load. No other food processing subsector has the same level of overall environmental impact as fish processing and fish products. Vegetable and animal oils and fats (ranking $24^{\text {th) }}$ is the next most significant; and production, processing, and preserving of meat and meat products, including abattoirs, ranks $31^{\text {st }}$.

Tanneries and leather products, especially footwear is a significant group of industries for pollution loading, the other manufacturing sectors on the top 30 list include those concerned with pulp and paper products, various kinds of wood products and furniture. As one moves down the list, some sectors score highly only on one or two forms of pollution. The paperboard industries have very high water pollution loadings but are of lesser concern for air and land. Similarly, ceramics, cement, lime and plaster, vegetable and animal oils and fats, soap and detergents, electrical equipment and refined petroleum products are all associated with industries that have a distinctive pollution profile. Yet, they require priority attention from environmental regulators because of their high overall pollution index rating.

\section{A. Air Pollution Index}

The air pollution index and the overall National Pollution Index are similar for the most significant sectors (Figures 2.2 through 2.5). A key difference is the appearance of two of the VSIC-4 ceramics categories: "structural non-refractory clay and ceramic products" appearing $2^{\text {nd }}$ in the air pollution index ranking while the other, "refractory ceramic products" is $19^{\text {th }}$. Another significant feature of the air index is the increasing importance of a range of wood and paper product categories (wood, cork, straw and plaiting materials, sawmilling and planing of wood, furniture, veneer sheets, plywood, laminated boards, and particle board). Those categories are often associated with others covering volatile chemical and paint products. Clothing and textiles also increase in importance as do various categories of food processing. In fact many of the small- to medium-scale manufacturing activities, which are often found in craft villages, appear high in the air pollution index (for example, "other manufacturing" VSIC-4 category and some ceramic, handicraft, furniture, and metallurgy activities). ${ }^{30}$

\section{B. Land Pollution Index}

Two groups of industries stand out in the land pollution index rankings - metal manufacturing and chemical production (Table 2.2). Metal manufacturing includes 9 of the top 30 ranked VSIC-4 categories, including basic iron and steel; casting of metals, their forging, pressing, stamping and roll-forming; powder metallurgy; the treatment and coating of metals; general mechanical engineering; and a wide range of fabricated metal products. Even the recycling of metal waste and scrap is a significant industry for its land pollution load. In the chemicals industries there are those plants concerned with fertilizers and nitrogen compounds, pesticides and other agro-chemical products, pharmaceuticals, medicinal chemicals and botanical products, and other categories of basic chemicals and chemical products. The other notable industry groups are textiles and clothing and tanneries and leather products, including footwear which is ranked $2^{\text {nd }}$ under this index (and $2^{\text {nd }}$ for air). Like fish products, footwear dominates because of the large scale of operations in Vietnam.

30. Other manufacturing VSIC-4 category includes manufacture of brooms and brushes, pens and pencils, hand-operated devices for printing, baby carriages, umbrellas, cigarette lighters and matches, articles of personal use: smoking pipes, combs, hair slides, scent sprays; linoleum and hard non-plastic surface floor coverings, imitation jewelry, miscellaneous articles: candles, tapers and the like, artificial flowers, fruit and foliage, jokes burial caskets, etc. and, taxidermy activities. 
Table 2.2. Land Pollution Index Ranking for Top 30 Sectors

\begin{tabular}{|c|c|c|c|c|}
\hline Rank & Industrial sector (VSIC-4) & Metals & Chemicals & Land index \\
\hline 1 & Fertilizers and nitrogen compounds & 4 & 1 & 3 \\
\hline 2 & Footwear & 3 & 5 & 4 \\
\hline 3 & Basic iron and steel & 1 & 6 & 4 \\
\hline 4 & Casting of non-ferrous metals & 2 & 8 & 5 \\
\hline 5 & Basic chemicals, except fertilizers and nitrogen compounds & 11 & 3 & 7 \\
\hline 6 & Processing and preserving of fish and fish products & 12 & 2 & 7 \\
\hline 7 & Plastics products & 9 & 4 & 7 \\
\hline 8 & Forging, pressing, stamping and roll-forming of metal; powder metallurgy & 5 & 16 & 11 \\
\hline 9 & Other rubber products & 15 & 9 & 12 \\
\hline 10 & Wearing apparel, except fur apparel & 10 & 14 & 12 \\
\hline 11 & Other chemical products n.e.c. & 18 & 7 & 13 \\
\hline 12 & Casting of iron and steel & 7 & 19 & 13 \\
\hline 13 & Structural non-refractory clay and ceramic products & 6 & 22 & 14 \\
\hline 14 & Treatment and coating of metals; general mechanical engineering & 8 & 24 & 16 \\
\hline 15 & Pesticides and other agro-chemical products & 21 & 11 & 16 \\
\hline 16 & Preparation and spinning of textile fibres; weaving of textiles & 20 & 23 & 22 \\
\hline 17 & Tanning and dressing of leather & 29 & 17 & 23 \\
\hline 18 & Furniture & 35 & 12 & 24 \\
\hline 19 & Other fabricated metal products n.e.c. & 17 & 31 & 24 \\
\hline 20 & Basic precious and non-ferrous metals & 13 & 36 & 25 \\
\hline 21 & Non-structural non-refractory ceramic ware & 19 & 33 & 26 \\
\hline 22 & Insulated wire and cable & 16 & 35 & 26 \\
\hline 23 & Recycling of metal waste and scrap & 14 & 39 & 27 \\
\hline 24 & Other manufacturing n.e.c. & 28 & 28 & 28 \\
\hline 25 & Pharmaceuticals, medicinal chemicals and botanical products & 48 & 10 & 29 \\
\hline 26 & Pulp, paper and paperboard & 44 & 15 & 30 \\
\hline 27 & Other electrical equipment n.e.c. & 25 & 34 & 30 \\
\hline 28 & Cement, lime and plaster & 23 & 45 & 34 \\
\hline 29 & Structural metal products & 27 & 40 & 34 \\
\hline 30 & Articles of concrete, cement and plaster & 40 & 29 & 35 \\
\hline 31 & Paints, varnishes and similar coatings, printing ink and mastics & 49 & 21 & 35 \\
\hline 32 & Building and repairing of ships & 31 & 41 & 36 \\
\hline
\end{tabular}

Note: The first quartile has no colored box (white/light green) and the second quartile is colored dark blue.

Source: Authors 


\section{Water Pollution Index}

Three industry groups dominate the water pollution index top 30 rankings. They relate to (a) paper and wood products, (b) chemicals and (c) metal processing. The first group includes corrugated paper and paperboard, particle board and plywood, and pulp processing. Soap, detergents, cleaning and polishing preparations, perfumes and toiletries are added to the other more dominant chemical categories including agro-chemical products and medical chemicals. The processing, treatment and fabrication of iron and steel and non-ferrous products, in addition to general mechanical engineering, appears consistently high in all three indexes, but especially for water and land. A broader group of food processing industries appear in the top 30 of the water pollution index rankings including the 48 sugar refineries and factories in Vietnam, processing and preserving of fruit and vegetables and "other food products" category that covers production of coffee products, packing of tea, manufacture of soups and broths, spices, sauces and condiments, and frozen meat and poultry dishes. As for the other indexes, fish processing is prominent.

\subsection{Sector Pollution Profiles}

Using the pollution indexes, the analysis now identifies the sectors that are most responsible for each pollutant load. Figures 2.2, 2.3 and 2.4 show the top 10 sectors in terms of their overall load to air, land, and water in Vietnam. For each sector the bars also indicate the relative shares of low, moderate, and highly toxic substances that comprise that load. The percentage of highly hazardous substances is quite variable, even among the top 10 by air pollution load. For example, refractory ceramic products is ranked $10^{\text {th }}$ in terms of air pollution load nationally, and has a pollution load classified over 90 percent as highly hazardous. In contrast, prepared animal feeds are the $6^{\text {th }}$ largest in terms of air pollution, but has less than 10 percent of its load classified as highly hazardous. The cement, ceramics, metallurgy and electrical equipment manufacture, and other manufacturing activities are of greatest concern for toxic air pollution (Figure 2.2). Close to 100 percent of the pollution load to air from the ceramics industries are toxic as is the pollution from "other manufacturing".
Figure 2.2. Top 10 sectors in terms of total national air pollution load and their percentage hazardous content (\%)

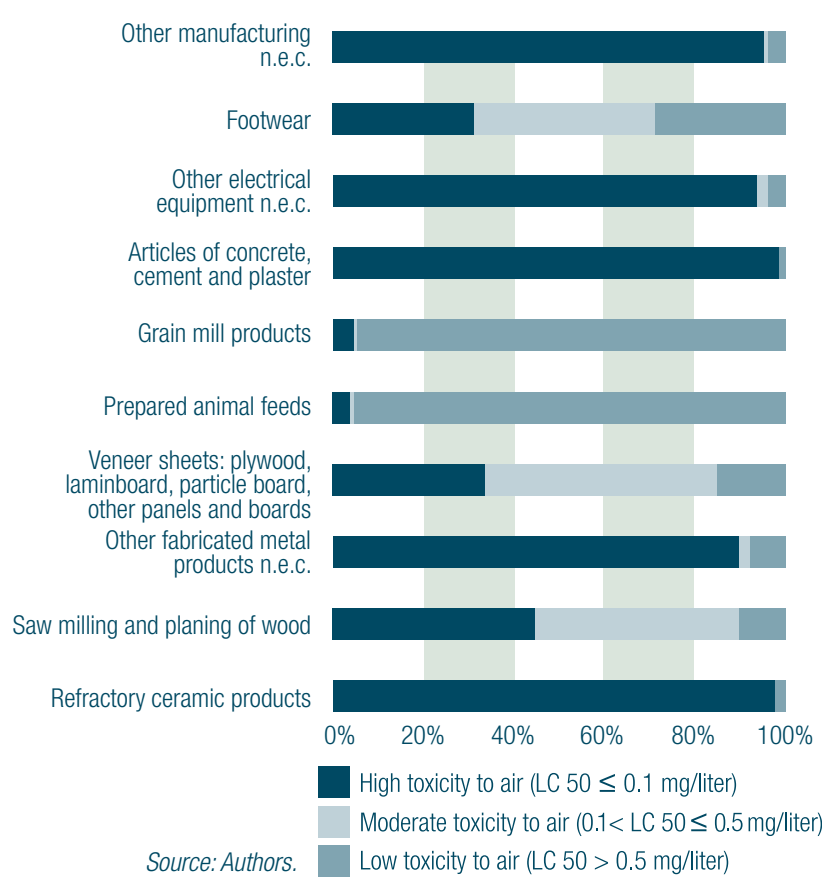

Both those sectors, though poorly regulated, are prominent in the family-based industries of craft villages. Cement plants have the highest hazardous content in their pollution to air than any other industry type. Their wide distribution throughout the country, exceptional growth rate and significant pollution dispersal would make the cement sector a top priority for more proactive pollution control.

Highly toxic pollutants to land, which includes sludge, liquids, metals and solid wastes, are found in the seafood processing, textiles, and chemicals sectors (Figure 2.3). Those three top ranking sectors are also of major concern for the toxicity of their effluent wastes to water, where they are joined by the pulp, paper and wood based industries, plastics production, and leather products, especially footwear (Figure 2.4). 
Figure 2.3. Top 10 sectors for total national land pollution load and their $\%$ hazardous content

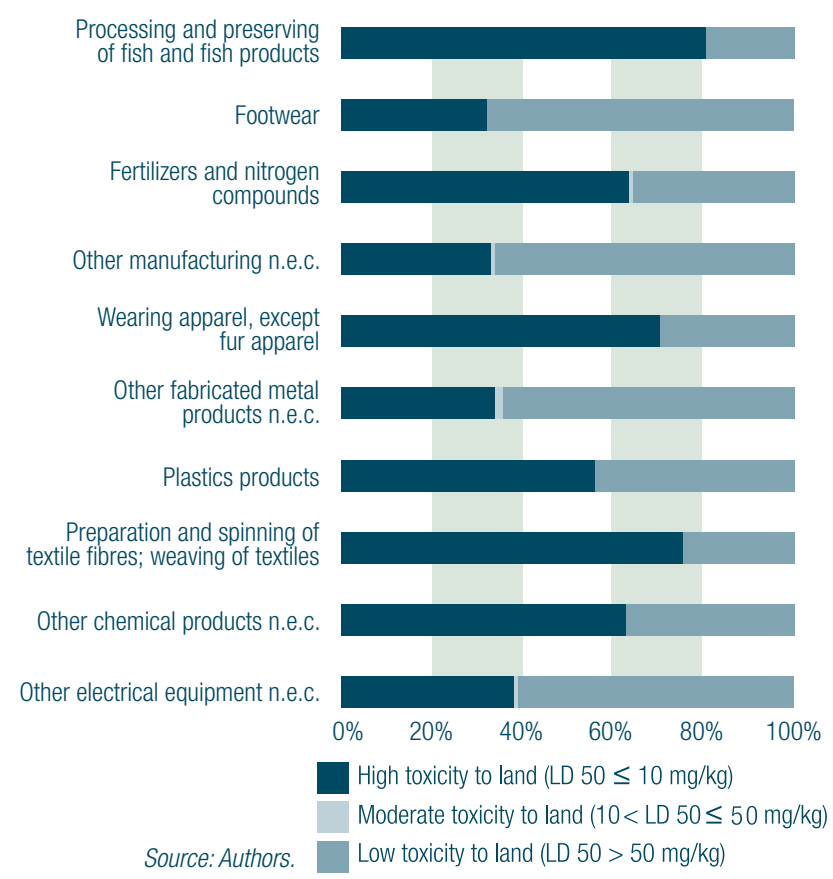

Figure 2.4. Top 10 sectors for total national water pollution load and their \% hazardous content

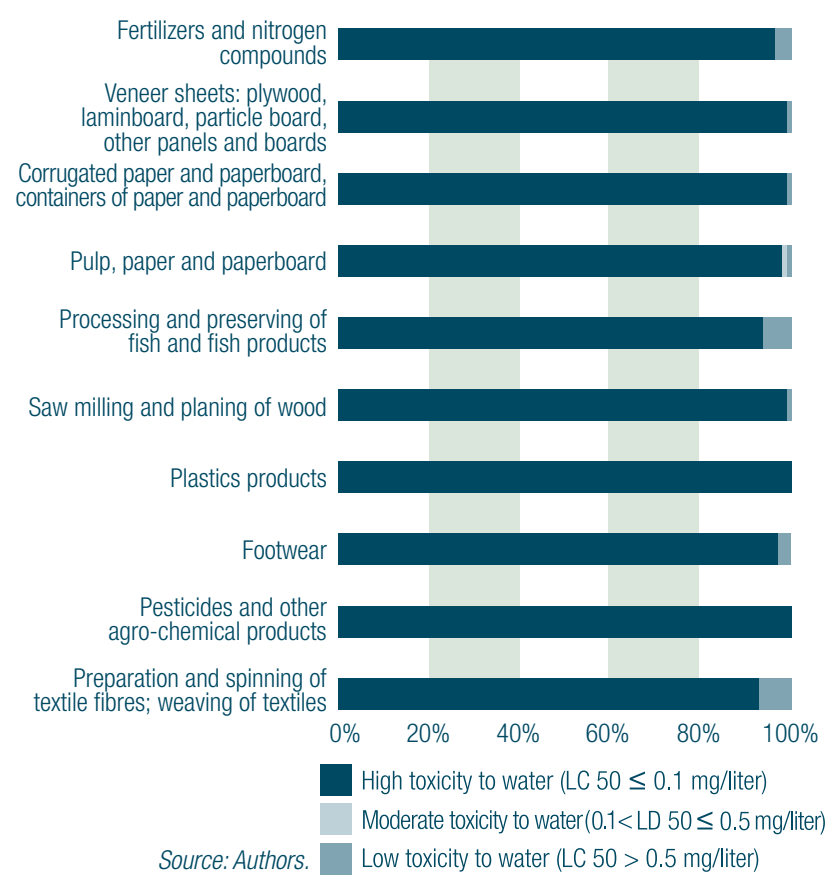

Toxic pollution to land and water is a growing, long-term problem in Vietnam due to the creation of numerous contaminated sites. Contamination is not always contained within a specific site. Hazardous substances may seep through the soil into groundwater, or be carried to nearby land and waterways in rainwater or on dust particles. Vapor and gases from contaminated land may present additional risks of exposure and odor. The pollution of ground and surface water by substances highly hazardous to human and aquatic life is especiallyserious because oftheir potentially wide disbursement, their persistence, and the ease with which they are ingested and absorbed by people directly in water or indirectly through concentration and transmission in the food chain.

Figures 2.5, 2.6, and 2.7 present those sectors whose pollution has the highest proportion of toxic substances, irrespective of the total load. Figure 2.5 shows that coke oven products rank highest in terms of the toxicity of their air emissions. However, this VSIC-4 category ranks $109^{\text {th }}$ in terms of total pollution load. The manufacture of musical instruments is $2^{\text {nd }}$ in the ranking of highly hazardous substances, due to the complex and volatile chemicals used in finishing. Yet, it ranks $110^{\text {th }}$ in total air pollution load.

Figure 2.5. Top 10 sectors in terms of the percentage of highly hazardous substances to air (\%)

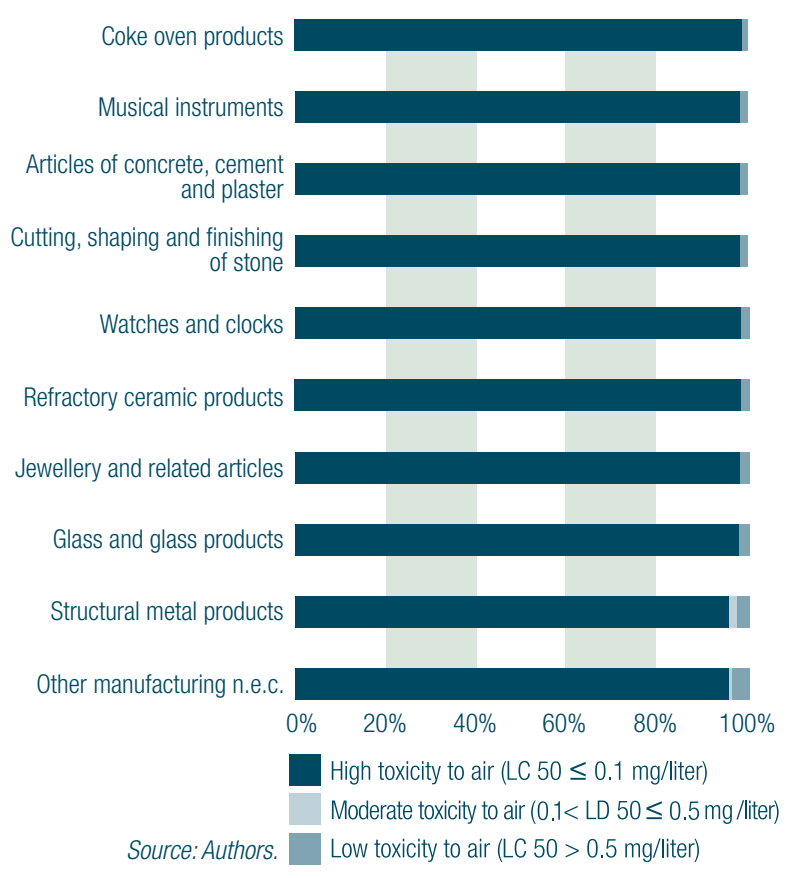


Among the sectors with the highest percentages of hazardous substances to land, the profile varies markedly with the rankings by pollution load (compare Figures 2.3 and Figure 2.6). In Figure 2.6, malt liquors, animal feedstock production, and grain mill products constitute sectors with the three highest percentages of highly hazardous substances. The process of brewing alcohol with poor, or non-existent, water recycling technology creates a toxic sludge that is quite often disposed of on land or dispersed across the landscape to dry out in standing landfills. Similarly animal feedstocks and grain milling sectors create sizeable quantities of hulls, shells, stalks, and steeps during the processing of raw materials and refining products. Collectively, these wastes are stockpiled in areas that begin to leach into groundwater supplies and affect surrounding communities.

For water resources the story is perhaps most alarming. Among the top 10 sectors ranked by highly hazardous substances, none of them possess pollution loads to water with less than 95 percent high hazard (Figure 2.7). Although the differences in ranking are almost trivial, pesticides, the manufacture of sporting goods, and musical instruments contain the largest shares of highly hazardous substances. In fact, the list is actually longer with 50 out of 129 sectors indicating a 90 percent or greater highly hazardous load.

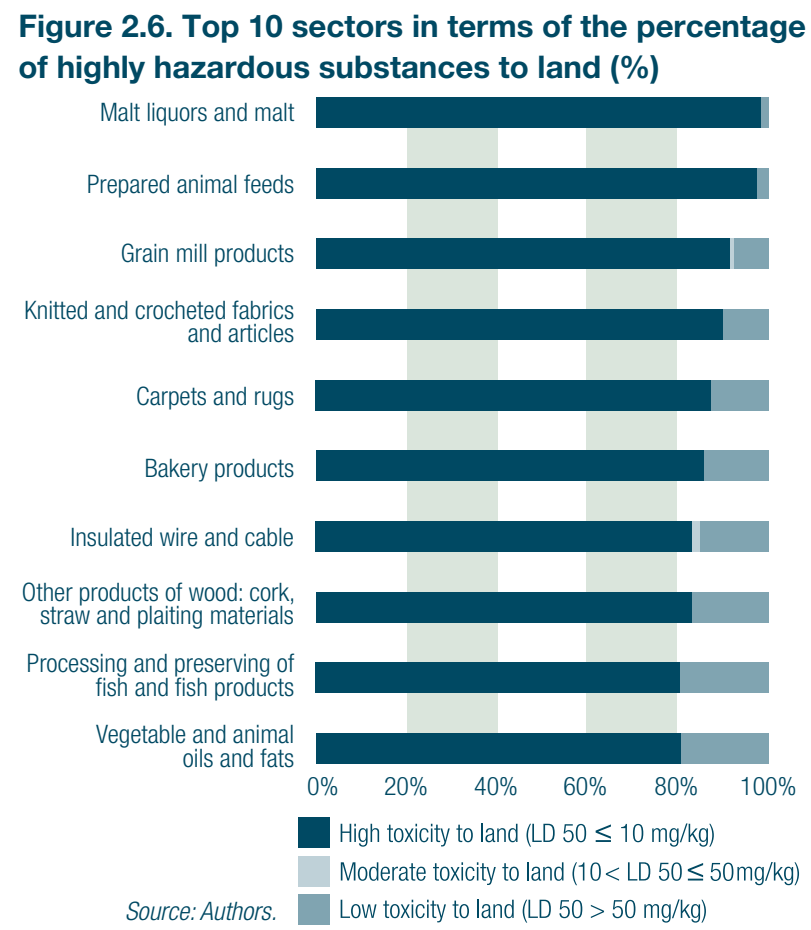

Figure 2.7. Top 10 sectors in terms of the percentage of highly hazardous substances to water (\%)

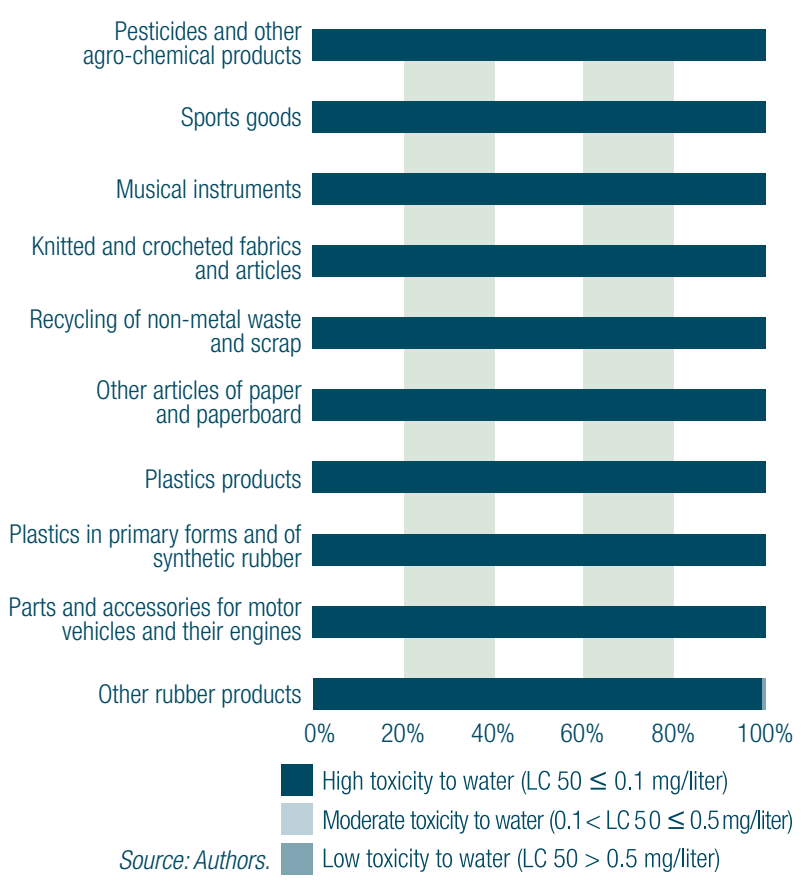

There are important reasons for identifying the most polluting sectors on a national basis. The strong emphasis on decentralization in all arms of government, including environmental management and regulation means that each province sets its own priorities according to local conditions. Yet, national government is still providing the overall regulatory framework of policies, laws, and orientations for local action. When it is clear that a manufacturing sector is having a cumulative impact on the environment, on public health, and on the productivity of other development sectors due to its pollution levels, then it becomes a national priority for control and management. The identity of those industry sectors that require the highest priority attention in the national industry pollution management plan were identified in this section. Among the following 8 industry groups, 30 of the 129 VSIC-4 manufacturing subsectors are consistently ranked at the top in all 4 of the pollution indexes and among the hazard rankings: 
(1) Chemicals industries:

(a) Fertilizers and nitrogen compounds (2412)

(b) Basic chemicals (except fertilizers and nitrogen compounds) (2411)

(c) Other chemical products n.e.c. (2429)

(d) Plastics products (2520)

(e) Other rubber products (2519)

(f) Pesticides and other agro-chemical products (2421)

(g) Pharmaceuticals, medicinal chemicals and botanical products (2423)

(h) Soap and detergents, cleaning and polishing preparations, perfumes and toilet preparations (2424)

\section{(2) Primary metals industries:}

(a) Basic iron and steel (2710)

(b) Casting of non-ferrous metals (2732)

(c) Forging, pressing, stamping and roll-forming of metal; powder metallurgy (2891)

(d) Casting of iron and steel (2731)

(e) Treatment and coating of metals; general mechanical engineering (2892)

(f) Recycling of metal waste and scrap (3710)

(g) Basic precious and non-ferrous metals (2720)

(h) Other non-metallic mineral products n.e.c. (2699)

\section{(3) Food processing:}

(a) Processing and preserving of fish and fish products (1512)

(b) Vegetable and animal oils and fats (1514)

(c) Meat processing and products (1511)

(4) Leather and leather products:

(a) Footwear (1920)

(b) Tanneries

\section{(5) Paper and wood products:}

(a) Pulp, paper and paperboard (2101)

(b) Corrugated paper and paperboard, containers of paper and paperboard (2102)

(c) Veneer sheets; plywood, laminated board, particle board, other panels and boards (2021)

(d) Furniture (3610)

\section{(6) Textiles:}

(a) Preparation and spinning of textile fibres; weaving of textiles (1711)

(b) Wearing apparel (except fur apparel) (1810)

\section{(7) Ceramics:}

(a) Structural non-refractory clay and ceramic products (2693)

(b) Refractory ceramic products" (2692) (added because of its high ranking on the air pollution index)

\section{(8) Non metal mineral products industry:}

(a) Cement, lime and plaster (2694)

The best environmental performers appear to be in those sectors where international companies have taken the lead in introducing best industry practice. For example, most sugar refineries in Vietnam have a poor environmental record. One or two internationally owned sugar factories have done well.

\subsection{Geographic Pollution Profiles}

In Vietnam, the geography of pollution is characterized by two distinguishing features. The first is the intimate relationship polluting plants have with surface water. That link is no coincidence. For centuries rivers, ponds, and lakes have been the main waste treatment facility in Vietnam. Industries tended to establish near surface water bodies acting as a means of transport, source of water, and a sink for flushing away waste. Even today, water bodies attract industry and remain the dominant pollution treatment facility used by industry. The second feature is the concentration of industry and pollution on the flood plains and in coastal zones. This also stands to reason; it is where communities first settled, where soils are rich and towns and cities have grown. These areas give access to labor; easy transport; markets; and, of course, to flat land - always a key factor when locating industry. Both characteristics of pollution geography have important implications for inter-relationship of people with pollution, natural systems, and other economic activities. What follows is a snapshot of the geographic distribution of pollution where at the commune level some provinces have the highest estimated pollution loads in the country. 
Ho Chi Minh City and Hanoi stand out as having the highest overall ranking on the National Pollution Index (Table 2.3). Ho Chi Minh City scores highest on all four indexes. Of the provinces in the top 10 ranking, 4 are in the north, 1 in the center, and 5 in the south. Moving down the list, two clear pollution blocks or regions take shape - one in the north of Vietnam stretching from Phu Tho Province west of Hanoi all the way to Haiphong and Quang Ninh on the coast. The other pollution region is in the south and made up of a solid block of provinces from Binh Duong and Dong Nai down to the sea. Data also shows an overlap between the provinces in the top 10 ranking with the Northern and Southern
Economic Focal Regions. In the north, the provinces of Phu Tho and Thai Nguyen - ranked $6^{\text {th }}$ and $7^{\text {th }}$ on the National Pollution Index - fall outside the economic focal region but are intimately connected to it in a natural systems and socioeconomic sense. When the national pollution load is normalized by population, a similar pattern emerges for the highest pollution areas; however, it is distributed over a greater number of provinces. For example, Quang Binh and Cao Bang move up in ranking (darker in color in the Table) as do a number of interior provinces in the south and north. Thus on a per capita basis the impact of pollution is more widespread.

\section{Table 2.3. National Pollution Index Ranking for Top 30 Provinces}

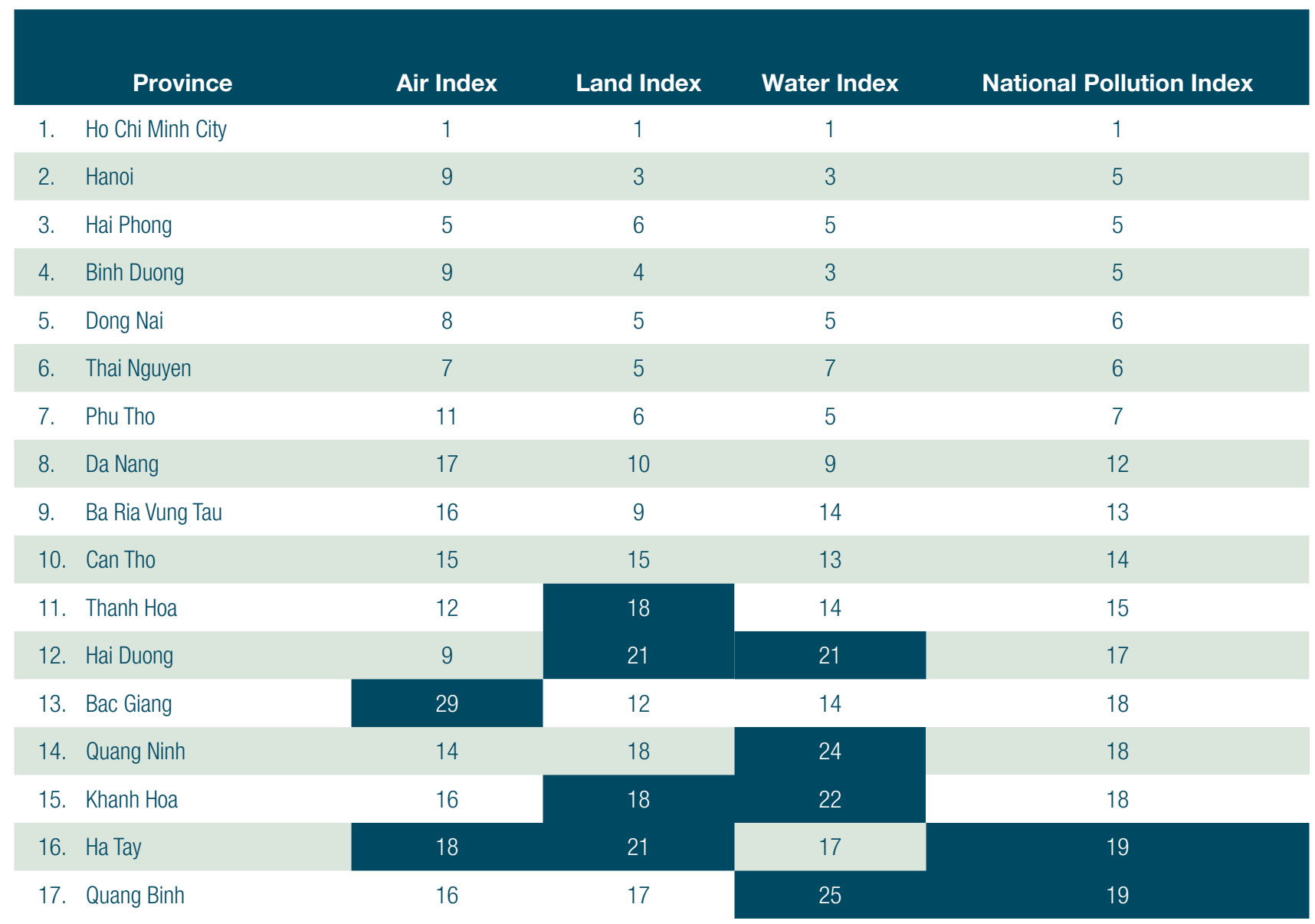




\begin{tabular}{|c|c|c|c|c|}
\hline Province & Air Index & Land Index & Water Index & National Pollution Index \\
\hline 18. Bac Ninh & 33 & 16 & 12 & 20 \\
\hline 19. Nghe An & 19 & 22 & 21 & 20 \\
\hline 20. Long An & 28 & 16 & 18 & 21 \\
\hline 21. Binh Dinh & 24 & 24 & 17 & 22 \\
\hline 22. Vinh Phuc & 30 & 18 & 23 & 24 \\
\hline 23. Hung Yen & 35 & 18 & 23 & 25 \\
\hline 24. Ninh Binh & 22 & 24 & 31 & 26 \\
\hline 25. Quang Nam & 30 & 27 & 25 & 27 \\
\hline 26. Ha Nam & 25 & 37 & 28 & 30 \\
\hline 27. Thai Binh & 27 & 28 & 37 & 31 \\
\hline 28. Ca Mau & 29 & 26 & 38 & 31 \\
\hline 29. Quang Ngai & 36 & 31 & 26 & 31 \\
\hline 30. Binh Thuan & 33 & 28 & 33 & 31 \\
\hline
\end{tabular}

Note: The first quartile has no colored box (white/light green), the second quartile is colored dark blue, and the third is medium blue. Source: Authors.

\section{Air Pollution}

If just air pollution is considered, then 3 provinces - Thanh Hoa, Hai Duong, and Quang Ninh - join the top 10 ranking, all in the north of the country, pushing others further down the list. In fact, 7 of the top 10 provinces for air pollution are located in the north. Some of the highest ranked sectors for air pollution are concentrated in this region, such as fertilizer producers (e.g., Phu Tho), basic iron and steel (e.g., Thai Nguyen) and ceramics. Hai Duong Province has the highest number of cement factories in the country and with Thanh Hoa the highest number of workers employed in that industry. The Government is pursuing a strong decentralization strategy for the cement industry so it is likely that as more plants are built it will influence the air pollution geographic profile of the country over the next few years.
Quang Ninh is the center of Vietnam's coal region. The Vietnam National Coal and Mineral Industries Group (Vinacomin) is giving priority to the construction of thermoelectric power plants located near the coal-mining areas. The coal industry is experiencing very high growth. In 2005, it reached the target set by the Government for 2010 of 24 million tons. This expansion is generating a multiplier effect in manufacturing in Quang Ninh and neighboring provinces. Hai Duong, an adjoining province, is undergoing a surge in large-scale industrial production more than 20 percent over the past year, as is Thanh Hoa just a little to the south along the coast.

\section{Land Pollution}

There are two distinct land pollution blocks: one in the south with four provinces (Ho Chi Minh City, Dong Nai, Ba Ria Vung Tau, and Binh Duong) and one in the north around 
Hanoi, including Phu Tho, Thai Nguyen, Vinh Phuc, Bac Ninh, and Hung Yen. Bac Giang, The northern block around Hanoi joins the top 10 for the first time. It is among the top provinces producing fertilizers and is ranked first for pollution load to land. Fertilizer plants are responsible for 81 percent of pollution.

Moderate levels of land pollution are found quite evenly distributed in the coastal and delta provinces, more so than for pollution to air and water. The top sectors responsible for land pollution - fish processing, basic iron and steel, and fertilizers - are found in those coastal and delta locations. Looking closely at fish processing, for example, although there is a concentration of plants south of the country in and around Ho Chi Minh City (80 percent of the total), they are also spread out along the coast down from Quang Ninh, through Danang and Khanh Hoa Province (mainly around Nha Trang) and across the Mekong delta provinces.

\section{Water Pollution}

The top 10 provinces stand out with high loads in the 4 types of water pollutants covered in the index (Table 2.4). Other provinces have a more variable profile. Ninh Binh for example, which is ranked $30^{\text {th }}$ on the water pollution index, is very high for TSS but relatively low for the other water pollution parameters. Analyzing that province further, two dominant industries from a pollution standpoint are VSIC-4 categories basic iron and steel and casting of iron and steel. Those two sectors are responsible for 93 percent of TSS releases in Ninh Binh Province. Binh Dinh Province, which ranks $15^{\text {th }}$ on the water pollution index, ranks high for BOD but has only a moderate ranking for the other water pollution parameters. The reason for this profile is clear. Binh Dinh is a center for paper and paperboard production, a sector ranked highest nationally for BOD pollution.

Table 2.4. National Pollution Index Ranking for Top 30 Provinces

\begin{tabular}{|c|c|c|c|c|c|c|}
\hline & Provinces & BOD & TSS & $\begin{array}{l}\text { Metals } \\
\text { to water }\end{array}$ & $\begin{array}{c}\text { Chemicals } \\
\text { to water }\end{array}$ & Water Index \\
\hline 1. & Ho Chi Minh city & 1 & 1 & 1 & 1 & 1 \\
\hline 2. & Hanoi & 4 & 5 & 2 & 2 & 3 \\
\hline 3. & Binh Duong & 2 & 4 & 3 & 4 & 3 \\
\hline 4. & Hai Phong & 6 & 3 & 4 & 6 & 5 \\
\hline 5. & Dong Nai & 3 & 6 & 6 & 5 & 5 \\
\hline 6. & Phu Tho & 5 & 7 & 5 & 3 & 5 \\
\hline 7. & Thai Nguyen & 7 & 2 & 7 & 10 & 7 \\
\hline 8. & Da Nang & 10 & 8 & 9 & 9 & 9 \\
\hline 9. & Bac Ninh & 8 & 10 & 13 & 15 & 12 \\
\hline & Can Tho & 11 & 15 & 15 & 11 & 13 \\
\hline
\end{tabular}

Source: Authors 


\section{A. Pollution Profiles for Top 5 Provinces}

Using the pollution index and ranking method, Table 2.5 shows the top 10 provinces and the districts and communes within them with the highest aggregate pollution loads. The table shows only the top 10 communes for each province. ${ }^{31}$ It is possible to rank all communes for pollution load within every province countrywide.

The data in Table 2.5 show the top 10 communes usually account for most provincial pollution load ranging from 78 percent for Ba Ria Vung Tau to 97 percent in Thai Nguyen. Pollution load is also concentrated in few communes in $\mathrm{Ho}$ Chi Minh City and Hanoi but not to the extent of the other top ranked provinces. Those 2 main cities of Vietnam have more mature and diverse economies more evenly distributed throughout their territory. The top 10 communes - out of 300 in Ho Chi Minh City - account for 49 percent of the pollution load in the province. In Hanoi it is 33 percent; but, if the next 5 communes are added from the overall communal ranking in the province, the proportion of the total load quickly passes 50 percent.

31. As the estimates move to local level the methods used in the GSO survey create some distortions in the results. In some situations the GSO survey gave the address of factories as their headquarters in capital cities rather than their actual geographic location. This was done when individual factories are part of a larger company but do not have independent authority over their accounts. Inevitably, this tends to distort the pollution estimates. Large cities, provincial capitals, and communes where companies have their headquarters will tend to show higher pollution loads than is actually the case; and industrial areas outside cities will tend to show lower pollution loads than is actually the case. 
Table 2.5. Local government areas with highest pollution load - Top 10 provinces and their communes ${ }^{a}$

\begin{tabular}{|c|c|c|c|c|c|}
\hline $\begin{array}{l}\text { Provinces with } \\
\text { highest pollution } \\
\text { loads }^{\text {b }}\end{array}$ & $\begin{array}{l}\text { Economic } \\
\text { Focal Region }\end{array}$ & $\begin{array}{l}\text { Districts with highest } \\
\text { pollution loads }\end{array}$ & \multicolumn{2}{|c|}{$\begin{array}{l}10 \text { communes with highest } \\
\text { pollution loads }\end{array}$} & $\begin{array}{l}\% \text { of total provincial } \\
\text { pollution load in top } \\
10 \text { communes }\end{array}$ \\
\hline 1. Ho Chi Minh City & South & 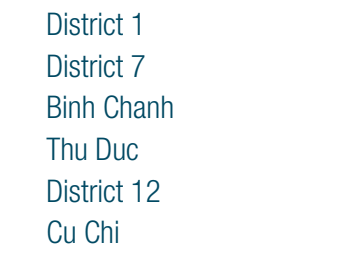 & 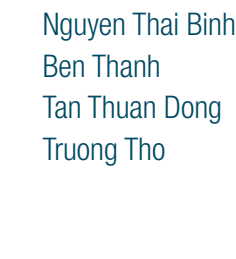 & 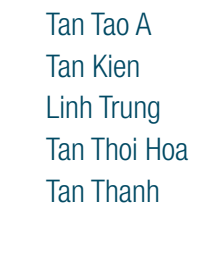 & 49 \\
\hline 2. Hanoi & North & 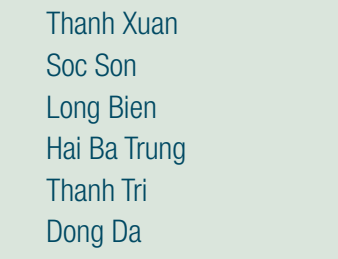 & $\begin{array}{l}\otimes \text { Phuong Liet } \\
\text { Quang Tien } \\
\otimes \text { Sai Dong } \\
\otimes \text { Duc Giang } \\
\text { Gia Thuy }\end{array}$ & 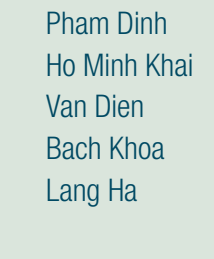 & 33 \\
\hline 3. Hai Phong & North & $\begin{array}{l}\otimes \text { Hong Bang } \\
\otimes \text { Thuy Nguyen } \\
\otimes \text { Ngo Quyen } \\
\otimes \text { An Hai } \\
\otimes \text { Le Chan }\end{array}$ & 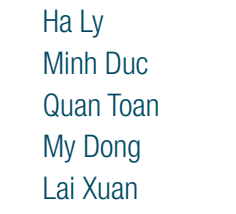 & 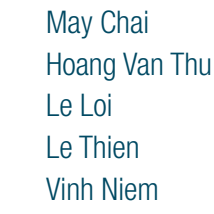 & 70 \\
\hline 4. Binh Duong & South & 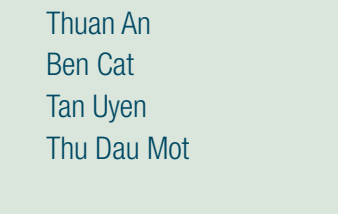 & 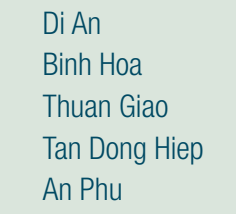 & 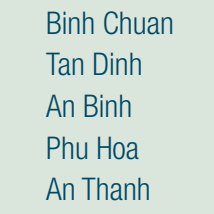 & 77 \\
\hline 5. Dong Nai & South & 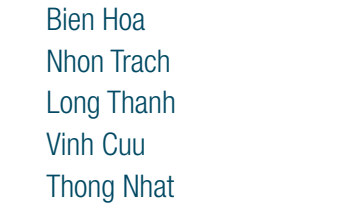 & $\begin{array}{l}\otimes \text { An Binh } \\
\otimes \text { Long Binh } \\
\otimes \text { Phuoc Thien } \\
\otimes \text { Long Binh Tan } \\
\otimes \text { Hoa An }\end{array}$ & 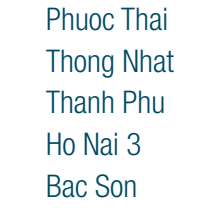 & 82 \\
\hline 6. Thai Nguyen & - & 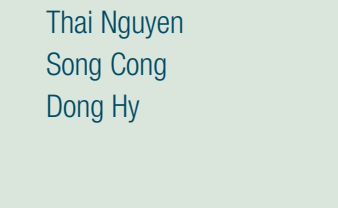 & 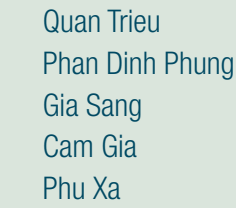 & 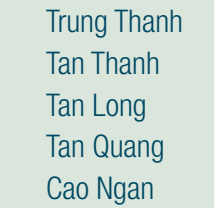 & 97 \\
\hline
\end{tabular}




\begin{tabular}{|c|c|c|c|c|c|}
\hline $\begin{array}{l}\text { Provinces with } \\
\text { highest pollution } \\
\text { loads }^{\text {b }}\end{array}$ & $\begin{array}{l}\text { Economic } \\
\text { Focal Region }\end{array}$ & $\begin{array}{l}\text { Districts with highest } \\
\text { pollution loads }\end{array}$ & \multicolumn{2}{|c|}{$\begin{array}{l}10 \text { communes with highest } \\
\text { pollution loads }\end{array}$} & $\begin{array}{l}\% \text { of total provincial } \\
\text { pollution load in top } \\
10 \text { communes }\end{array}$ \\
\hline 7. Phu Tho & - & 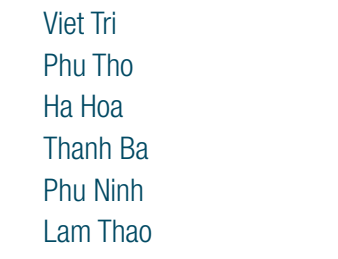 & $\begin{array}{l}\otimes \text { Viet Tri } \\
\nabla \text { Tien Cat } \\
\nabla \text { Tho Son } \\
\otimes \text { Ben Got } \\
\nabla \text { Thuy Van }\end{array}$ & $\begin{array}{l}\text { 叉 Phong Chau } \\
\text { Ha Hoa town } \\
\text { Thanh Ba town } \\
\text { P Phong Chau town } \\
\text { Lam Thao town }\end{array}$ & 96 \\
\hline 8. Da Nang & Central & 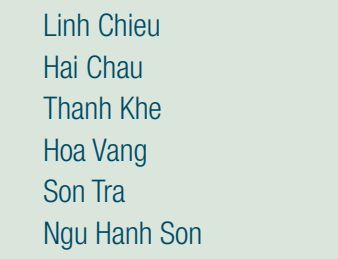 & 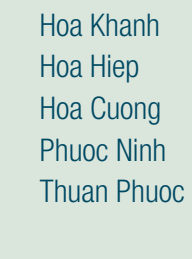 & 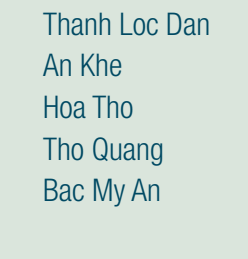 & 88 \\
\hline 9. Ba Ria Vung Tau & South & 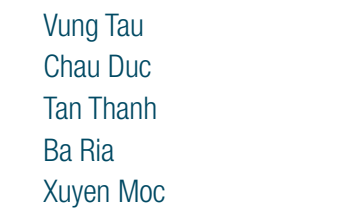 & 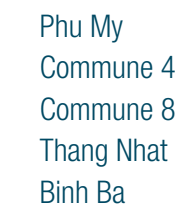 & 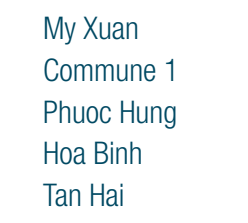 & 78 \\
\hline 10. Can Tho & - & $\begin{array}{l}\otimes \text { Ninh Kieu } \\
\otimes 0 \text { Mon } \\
\otimes \text { Binh Thuy } \\
\otimes \text { Cai Rang } \\
\otimes \text { Thot Not } \\
\otimes \text { Co Do }\end{array}$ & 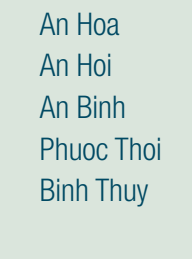 & 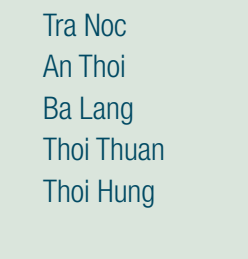 & 96 \\
\hline
\end{tabular}

${ }^{a}$ Highest pollution load in terms of the overall pollution load, across all three media.

${ }^{b}$ Provinces are listed in descending order of the overall pollution index ranking. For the Central Economic Focal Region only Danang appears in the top 10. Quang Nam and Thua Thien Hua fall well down in the National Pollution Index ranking coming $25^{\text {th }}$ and $27^{\text {th }}$, respectively.

Source: Authors 
The ranking provides an initial insight into those communes nationwide that might need attention and support in tackling their pollution problems. Interestingly, Hanoi does not have a commune in the national top 30, and Ho Chi Minh City communes are not on top. Two other significant findings are that the number of plants and the number of workers are not the key factor in estimates of pollution load. The main determinant is the sector involved. Cam Gia Commune in Thai Nguyen Province comes out on top of the national commune pollution ranking - but only 5 factories contribute most to the total pollution load in that commune. To get a better sense of the situation nationwide, the top 10 communes from Thua Thien Hue and Quang Nam Provinces (neighboring Danang) and Thanh Hoa were included in the ranking exercise. This brought in more of the provinces from central Vietnam even though they are relatively low on national rankings of provinces. It was found that Ba Dinh Commune in Thanh Hoa ranked $2^{\text {nd }}$ nationally and that 2 communes from Thua Thien Hue are on the top 30 list.

\section{(1) Ho Chi Minh City}

Ho Chi Minh City is the most significant economic center in the country. The city's annual GDP growth is around 12 percent and industrial production growth more than 15 percent. It has more than 30,000 large- to small-scale industries with close to 500,000 workers contributing more than 30 percent of total national industrial production value. The Dong Nai River and ground wells provide the city's water supply. The city sewerage discharges waste and runoff directly into seven canal systems. Wastewater backs up into the city when intense rain coincides with incoming tides, and during the dry season waste tends to stagnate within the city's waterways because of insufficient flow to flush the system.

There are some 90,000 registered industrial enterprises nationwide of which20,444 are concerned with manufacturing. Around 27 percent of all the country's manufacturing firms and 29 percent of the manufacturing work force are located in Ho Chi Minh City. Most firms in Ho Chi Minh City are concerned with clothing (15.4 percent); food and beverages, rubber and plastics, and fabricated metal products (around 10.5 percent each). Clothing and the footwear industries have the most workers at 47 percent of the total in manufacturing and the most firms at 15 percent of the total, followed by the plastic products industries with 9 percent.

Ho Chi Minh City is ranked $1^{\text {st }}$ for all pollution parameters in the National Pollution Index. Table 2.6 lists the largest manufacturing sectors in Ho Chi Minh City. Table 2.7 lists the dominant polluting sectors in the city. The largest industries in terms of workers and number of firms also have high pollution loads. Footwear, for example, is responsible for 11 percent of releases to air (23 percent of metals and chemicals to air), 10 percent to land and 6 percent to water. The 478 plastic products factories release 10,13 , and 9 percent of the pollution load to air, land, and water, respectively. The cement industry in Ho Chi Minh City has 12 factories (2004 figures) with only 0.5 percent of the provincial workforce and is responsible for 24 percent of the air pollution load. Similarly, paper and paperboard is produced by 160 factories and only 0.8 percent of manufacturing workers but contributed 14 percent to the water pollution load. 
Table 2.6. Largest VSIC-4 manufacturing sectors in Ho Chi Minh City

\begin{tabular}{|c|c|c|c|c|c|}
\hline VSIC-4 & Manufacturing sector & No of workers & $\%$ & No of firms & $\%$ \\
\hline 1512 & Processing and preserving of fish and fish products & 19,603 & 2.4 & 98 & 1.8 \\
\hline 1554 & Soft drinks; production of mineral waters & 6,320 & 0.8 & 153 & 2.8 \\
\hline 1711 & Preparation and spinning of textile fibers; weaving of textiles & 30,645 & 3.7 & 131 & 2.4 \\
\hline 1810 & Wearing apparel, except fur apparel & 211,463 & 25.4 & 842 & 15.3 \\
\hline 1912 & Luggage, handbags, saddlery and harness & 26,189 & 3.1 & 101 & 1.8 \\
\hline 1920 & Footwear & 175,068 & 21.1 & 130 & 2.4 \\
\hline 2029 & Other products of wood; cork, straw and plaiting materials & 11,757 & 1.4 & 131 & 2.4 \\
\hline 2102 & $\begin{array}{l}\text { Corrugated paper and paperboard, containers of paper and } \\
\text { paperboard }\end{array}$ & 6,717 & 0.8 & 160 & 2.9 \\
\hline 2221 & Printing & 13,036 & 1.6 & 390 & 7.1 \\
\hline 2222 & Service activities related to printing & 526 & 0.1 & 36 & 0.7 \\
\hline 2520 & Plastics products & 35,045 & 4.2 & 478 & 8.7 \\
\hline 2811 & Structural metal products & 6,504 & 0.8 & 164 & 3.0 \\
\hline 2899 & Other fabricated metal products n.e.c. & 15,498 & 1.9 & 269 & 4.9 \\
\hline 3610 & Furniture & 21,269 & 2.6 & 170 & 3.1 \\
\hline \multirow[t]{3}{*}{3699} & Other manufacturing n.e.c. & 11,868 & 1.4 & 122 & 2.2 \\
\hline & Total of largest sectors & 591,508 & 71.3 & 3,375 & 61.5 \\
\hline & Total in Ho Chi Minh City & 831,548 & 100 & 5,496 & 100 \\
\hline
\end{tabular}

Note: Listing based on those sectors contributing 2 percent or more to employment or on number of firms in the province. Source: Authors. 
Table 2.7. Main polluting manufacturing sectors in Ho Chi Minh City VSIC-4 sectors contributing more than $5 \%$ to a pollutant to air, land and water*

\begin{tabular}{|c|c|c|}
\hline Air & Land & Water \\
\hline $\begin{array}{l}\nabla \text { Basic iron and steel } \\
\nabla \text { Cement, lime and plaster (24\%) } \\
\nabla \text { Corrugated paper and paperboard, } \\
\text { containers of paper and paperboard } \\
\nabla \text { Footwear (11\%) } \\
\nabla \text { Forging, pressing, stamping and roll-forming } \\
\text { of metal; powder metallurgy } \\
\nabla \text { Other rubber products } \\
\nabla \text { Plastics products (10\%) } \\
\nabla \text { Processing and preserving of fish and fish } \\
\text { products } \\
\nabla \text { Production, processing and preserving of } \\
\text { meat and meat products } \\
\nabla \text { Wearing apparel, except fur apparel }\end{array}$ & 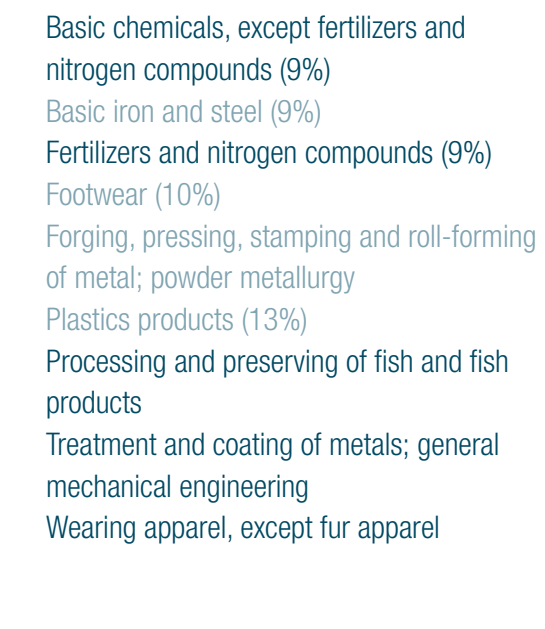 & 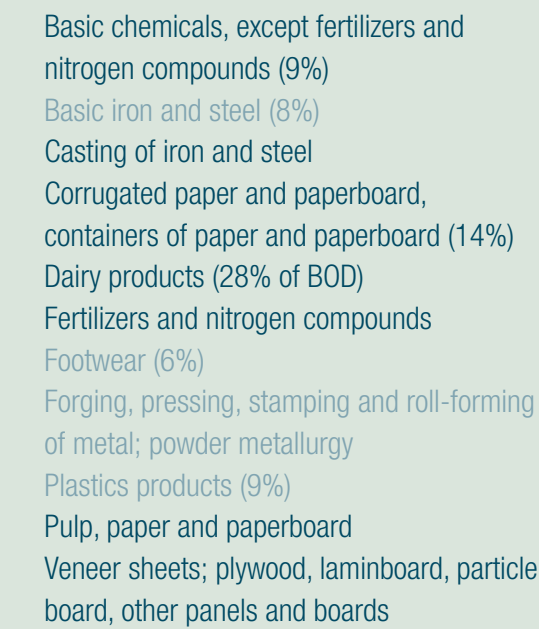 \\
\hline
\end{tabular}

* More than 5 percent to any of the following pollution parameters within the provinces: Air - $\mathrm{SO}_{2}, \mathrm{NO}_{2}, \mathrm{VOC}, \mathrm{PM}-10$, TSP, metals, chemicals; Land - metals, chemicals; Water — BOD, TSS, metals, chemicals.

Source: Authors

Fertilizers and basic chemicals together contribute 18 percent to land and 18 percent to the water pollution load. The point to emphasize here is the importance of priority setting in the pollution management strategy. It appears that just 12 cement plants and 29 fertilizer and basic chemical factories are the most significant per unit contributors to Ho
Chi Minh City's air, water and land pollution. But Table 2.7 shows that fish products, plastics, footwear and paper products are major contributors to total pollution load in the province and would each require comprehensive sector pollution management strategies. 
Table 2.8. Ranking of sectors with highest estimated pollution loads in Ho Chi Minh City

\begin{tabular}{|c|c|c|c|c|c|}
\hline & Sector & $\begin{array}{l}\text { Air pollution } \\
\text { load (tons/yr.) }\end{array}$ & $\begin{array}{l}\text { Land pollution } \\
\text { load (tons/yr.) }\end{array}$ & $\begin{array}{c}\text { Water } \\
\text { pollution load } \\
\text { (tons/yr.) }\end{array}$ & $\begin{array}{c}\text { Overall } \\
\text { pollution load } \\
\text { (tons/yr.) }\end{array}$ \\
\hline 1. & Cement, lime and plaster & 18347.1 & 21.5 & 236.0 & 6201.5 \\
\hline 2. & Processing and preserving of fish and fish products & 10805.2 & 1200.2 & 514.4 & 4173.2 \\
\hline 3. & Plastics products & 7232.3 & 3642.4 & 535.7 & 3803.5 \\
\hline 4. & Basic iron and steel & 979.8 & 906.5 & 8244.3 & 3376.9 \\
\hline 5. & Footwear & 4965.6 & 1836.7 & 2082.4 & 2961.5 \\
\hline 6. & $\begin{array}{l}\text { Corrugated paper and paperboard, containers of } \\
\text { paper and paperboard }\end{array}$ & 2851.6 & 317.2 & 5652.4 & 2940.4 \\
\hline 7. & Fertilizers and nitrogen compounds & 1231.5 & 2612.8 & 1186.9 & 1677.1 \\
\hline 8. & $\begin{array}{l}\text { Basic chemicals, except fertilizers and nitrogen } \\
\text { compounds }\end{array}$ & 1216.0 & 2592.9 & 794.2 & 1534.4 \\
\hline 9. & $\begin{array}{l}\text { Production, processing and preserving of meat and } \\
\text { meat products }\end{array}$ & 3005.4 & 323.2 & 75.4 & 1134.7 \\
\hline 10. & Pulp, paper and paperboard & 1101.1 & 145.5 & 2153.5 & 1133.4 \\
\hline
\end{tabular}

Source: Authors

In Ho Chi Minh City, the top 10 (3 percent) communes contribute more than 49 percent of the total pollution load in the province. ${ }^{32}$ Within each commune the situation is the same - pollution releases are geographically concentrated, often associated with just a few factories. In Truong Tho, one cement, lime and plaster plant contributed 97 percent of total pollution load in the commune. In Benh Tanh Commune the figures are equally dramatic. There, one basic iron and steel factory contributes 61, 86, and 99 percent to the air, land, and water pollution load, respectively, and is responsible for 93 percent of the total pollution load. In Nguyen Thai Binh one cement plant releases 87 percent of the air pollution load from manufacturing industry in the commune, and one factory producing veneer sheets and particle board releases 95 percent of the water pollution load.

The situation is not quite so clear cut for land pollution. The same veneer sheet factory releases 52 percent to the air pollution load, and another factory involved in insulated wire and cable products contributes a further 19 percent. But in

32. The importance of ground truthing the GSO dataset became evident when analyzing the Ho Chi Minh City commune data. In Ben Nhge Commune, the database lists one cement plant and one basic chemicals plant, which would contribute significantly to the total pollution load. A member of the Technical Advisory Group pointed out that these plants are not located in the commune; their headquarters are there but the plants are many kilometers away, some in other provinces. The GSO survey recorded the headquarter address for all plants within the companies concerned. The study team initiated a check of commune data in the top 10 provinces and found it mostly to be accurate and the overall rankings valid. But anomalies in the data of this kind were found. Field verification of the estimates will be essential when acting on the priorities identified in this study. 
terms of total load, the cement and particle board factories together contribute 98 percent. One cement factory releases 98 percent of the pollution load to air and 55 percent to water in Truong Tho Commune. The cement plants are large, in this case with more than 1,000 workers. By weight, that plant contributes 98 percent of the total pollution releases in the commune. From the examples so far at communal level, it is evident that the air, land and water indexes and the overall aggregate index are useful tools in setting priorities for focused field inspection and monitoring. If specific pollutants (like the most toxic pollutants for example) are the concern, then the priorities might change.

In Tan Tao A, 2 footwear factories dominate the pollution situation releasing 74,63 , and 38 percent communal pollution loads to air, land, and water, respectively. A similar story is found in Tan Kien where 3 factories contribute the largest share to the pollution load, in this case 2 fertilizer plants and 1 relatively small cement factory. Together those enterprises release 58 percent of the load to air, while the fertilizer plants alone contribute 75 and 52 percent to land and water, respectively.

In some communes the pollution load is concentrated, but among more factories. In Linh Trung, for example, 13 of 68 plants are responsible for 70 percent of the total pollution load. Of the highest polluting group, 5 footwear factories contribute 35 and 33 percent of the release to air and land, respectively, and 1 casting of iron and steel plant contributes 40 percent of water pollution load. A similar situation is found in Tan Thanh and Tan Thoi Hoa communes. In Tan Thanh, 23 of 100 factories contribute 80 percent of the total communal pollution load from manufacturing industries (most from 13 plastics products, 2 vegetable and animal oils and fats, 2 casting of iron and steel, and 3 preparation and spinning of textiles plants). In Tan Thoi Hao, 65 percent of total pollution load comes from 2 meat and meat products and 2 other rubber products factories, but 16 plastic producers and 3 fish processing plants also contribute significantly. Finally, Tan Thuan Dong, one of the top 10 communes in Ho Chi Minh City, does not align strictly to the concentration trend. In that commune, there is a more even spread of the pollution load among the 140 plants. Although in Tan Thuan Dong, 10 plastic producers contribute 33 and 30 percent of the load to air and water, respectively, with 1 factory making watches and clocks releasing 25 percent to water.

\section{(2) Hanoi}

Hanoi is located on flat plains crossed by numerous rivers flowing eastwards to the sea. It has 4 main rivers - To Lich, Lu, Set, and Kim Nguu - and 29.7 kilometers of open canals for drainage. This extensive surface water system is critical in regulation of the city water and waste discharge. Administratively, Hanoi includes 7 inner and 5 suburban districts with a land area of 921 square kilometers. Over the last 5 years to 2005, the average annual growth of Hanoi's GDP was 10 percent. In 2002, Hanoi had 265 state-owned industries and 15,880 non-state industrial enterprises (175 cooperatives, 37 private enterprises, 305 joint enterprises, and 15,365 individual business households). In 2004, Hanoi had 2,754 registered manufacturing enterprises with close to 245,000 workers, the highest proportions involved in clothing manufacture (15.5 percent) and textiles (4.8 percent). Fabricated metal products, plastics products, printing, and footwear stand out for the largest share of employment for the Hanoi economy. In addition to 9 old industrial areas (established during the 1960s and 70s), Hanoi has developed 5 new concentrated industrial estates and 13 medium and small ones, none of which had an environmental management plan.

Basic iron and steel contributes most to the overall pollution load and particularly to water pollution (Tables 2.8 and 2.9) because of the 27 registered factories in this sector. The plastics industry is among other sectors that stand out more prominently for air and land pollution, but structural nonrefractory clay and ceramic products is estimated to be the most serious air polluter. Other chemical products is of greatest concern for land pollution, again followed by the production of plastics; collectively, the chemicals industries appear to be the most important group in Hanoi for all forms of pollution.

Among the top 10 communes within the province of Hanoi, the first 4 rank in the top quartile across many of the air, land, and water pollutants. Moving down the list (Table 2.5) this consistency begins to weaken confirming an earlier observation that pollution is highly skewed toward relatively few areas. It is expected that even within these communes, pollution is concentrated within a small number of sectors. The only other sector that represents a significant share is 
the basic iron and steel, which contributes 37 percent of water pollution. Another commune which displays a similar pattern of pollution intensity is Duc Giang, where the top sector is basic chemicals (with three firms) employing only 6 percent of the manufacturing workforce but contributing a large share of total pollution releases (69 percent of total air load, 93 percent of all land loadings, and 77 percent of all water loadings). The only other sector with a significant contribution is the veneer sheets and plywood sector with 18 percent of the water load.

Table 2.9. Main polluting manufacturing sectors in Hanoi VSIC-4 sectors contributing more than $5 \%$ to a pollutant to air, land and water*

Air

\ Articles of concrete, cement and plaster

$\nabla$ Basic iron and steel

$\triangle$ Casting of non-ferrous metals

$\checkmark$ Cement, lime and plaster (30\% of PM10)

$\otimes$ Corrugated paper and paperboard, containers of paper and paperboard

$\otimes$ Distilling, rectifying and blending of spirits; ethyl alcohol production

$\otimes$ Footwear

\ Motorcycles

\ Other chemical products n.e.c.

$\bigotimes$ Plastics products

凶 Preparation and spinning of textile fibres; weaving of textiles

叉 Structural non-refractory clay and ceramic products ( $47 \%$ of TSP)

\ Wearing apparel, except fur apparel

\section{Land}

\section{Water}

\ Basic chemicals, except fertilizers and nitrogen compounds

$\nabla$ Basic iron and steel

$\nabla$ Casting of non-ferrous metals

$\otimes$ Fertilizers and nitrogen compounds

\ Other chemical products n.e.c.

Q Plastics products

$\otimes$ Structural non-refractory clay and ceramic products nitrogen compounds

$\triangle$ Basic iron and steel

$\nabla$ Casting of iron and steel

$\otimes$ Dairy products ethyl alcohol production
\ Basic chemicals, except fertilizers and

\ Corrugated paper and paperboard, containers of paper and paperboard

$\otimes$ Distilling, rectifying and blending of spirits;

\ Fertilizers and nitrogen compounds

\ Motorcycles

叉 Other chemical products n.e.c.

$\otimes$ Pharmaceuticals, medicinal chemicals and botanical products

\ Plastics products

Q Railway and tramway locomotives and rolling stock

\ Veneer sheets; plywood, laminboard, particle board, other panels and boards

* More than 5 percent to any of the following pollution parameters within the provinces: Air — S02, NO2, VOC, PM-10, TSP, metals, chemicals; Land — metals, chemicals; Water — BOD, TSS, metals, chemicals.

Source: Authors. 
Table 2.10. Ranking of sectors with highest estimated pollution loads in Hanoi

\begin{tabular}{|c|c|c|c|c|c|}
\hline & Sector & $\begin{array}{l}\text { Air pollution } \\
\text { load (tons/yr.) }\end{array}$ & $\begin{array}{l}\text { Land pollution } \\
\text { load (tons/yr.) }\end{array}$ & $\begin{array}{c}\text { Water } \\
\text { pollution load } \\
\text { (tons/yr.) }\end{array}$ & $\begin{array}{c}\text { Overall } \\
\text { pollution load } \\
\text { (tons/yr.) }\end{array}$ \\
\hline 1. & Basic iron and steel & 502.1 & 464.5 & $4,224.7$ & $1,730.4$ \\
\hline 2. & Structural non-refractory clay and ceramic products & $3,435.0$ & 147.4 & 1.3 & $1,194.6$ \\
\hline 3. & Plastics products & $2,108.5$ & $1,061.9$ & 156.2 & $1,108.9$ \\
\hline 4. & $\begin{array}{l}\text { Corrugated paper and paperboard, containers of } \\
\text { paper and paperboard }\end{array}$ & $1,015.9$ & 112.9 & $2,013.7$ & $1,047.5$ \\
\hline 5. & Other chemical products n.e.c. & 953.9 & $1,570.3$ & 495.3 & $1,006.5$ \\
\hline 6. & $\begin{array}{l}\text { Basic chemicals, except fertilizers and nitrogen } \\
\text { compounds }\end{array}$ & 373.7 & 796.7 & 244.0 & 471.5 \\
\hline 7. & Casting of non-ferrous metals & 364.2 & 391.4 & 608.3 & 454.7 \\
\hline 8. & Railway and tramway locomotives and rolling stock & 153.7 & 102.9 & $1,032.7$ & 429.8 \\
\hline 9. & Fertilizers and nitrogen compounds & 306.9 & 651.2 & 295.8 & 418.0 \\
\hline 10. & Cement, lime and plaster & 999.8 & 1.2 & 12.9 & 337.9 \\
\hline
\end{tabular}

\section{(3) Hai Phong}

Hai Phong is a coastal city, located in the east of the northern coastal area, 120 kilometers from Hanoi. It is in a strategic position for access to domestic and international transportation networks via road network, railway, sea routes, inland waterways, and air. Industry and manufacturing play a significant role in the provincial economy comprising 37 percent of total GDP, along with a diverse set of activities in services and agriculture. Annual growth in the industrial sector averages 15-16 percent, and this expansion has been internalized by increasing per capita annual income by 50 percent since 2000 to US\$950-1,000. The goal of the province is to raise per capita income to US\$1,500 per year by 2010 by increasing investments in shipbuilding, production of construction materials, metallurgy and engineering, garment and textile, footwear production, chemical, plastic industries, and software industries. The strategic provincial plan also involves an increasing role for foreign direct investment and ownership. The goal is to reach an average occupation rate of 50 percent land area in industrial and export processing zones and to build more industrial parks for small- and medium-sized businesses.

The manufacturing sector is supplier of over 124,000 jobs with half of the firms representing over two-thirds of the employment. The remaining half of the manufacturing sector contains a large number of small-scale operations. In terms of employment, the largest is footwear (41.2 percent) with over 51,000 employees across 35 firms. The sector is also one of the largest in terms of export value, generating VND 2,990 billion in 2005 (or nearly US\$200 million). The second largest employer is in shipbuilding (8.7 percent) owing to its comparative geographical advantage on the coast. There is also significant presence in the wearing apparel sector with nearly 10,000 employees among 48 firms.

Two complementary sectors, basic chemicals and footwear, are major polluters across all three types of media, with footwear contributing 45 percent of the chemical load in Hai 
Phong. The three sectors of basic iron and steel, casting of iron and steel, and casting of non-ferrous metals rank among the top 10 most polluting sectors (Table 2.11). As they serve the second largest sector in the economy - shipbuilding and repair services - their relative contribution to overall emissions is quite high. ${ }^{33}$ Cement, lime and plaster is the largest sector according to the Air and Overall Index of pollution with 87 percent of air emissions sourced to only 9 firms. For Hai Phong targeting this sector would bring substantial economies of scale in air pollution reduction.

\section{Table 2.11. Ranking of sectors with highest estimated pollution loads in Hai Phong}

\begin{tabular}{|c|c|c|c|c|c|}
\hline & Sector & $\begin{array}{l}\text { Air pollution } \\
\text { load (tons/yr.) }\end{array}$ & $\begin{array}{l}\text { Land pollution } \\
\text { load (tons/yr.) }\end{array}$ & $\begin{array}{c}\text { Water } \\
\text { pollution load } \\
\text { (tons/yr.) }\end{array}$ & $\begin{array}{l}\text { Overall } \\
\text { pollution load } \\
\text { (tons/yr.) }\end{array}$ \\
\hline 1. & Cement, lime and plaster & $15,314.5$ & 18.0 & 197.0 & $5,176.5$ \\
\hline 2. & Casting of iron and steel & 670.4 & 575.1 & $5,984.5$ & $2,410.0$ \\
\hline 3. & Basic iron and steel & 359.9 & 332.9 & $3,028.0$ & $1,240.3$ \\
\hline 4. & $\begin{array}{l}\text { Basic chemicals, except fertilizers and nitrogen } \\
\text { compounds }\end{array}$ & 781.9 & $1,667.2$ & 510.6 & 986.6 \\
\hline 5. & Footwear & $1,462.0$ & 540.8 & 613.1 & 872.0 \\
\hline 6. & Processing and preserving of fish and fish products & $1,586.9$ & 176.3 & 75.5 & 612.9 \\
\hline 7. & Casting of non-ferrous metals & 439.2 & 472.0 & 733.6 & 548.3 \\
\hline 8. & $\begin{array}{l}\text { Corrugated paper and paperboard, containers of } \\
\text { paper and paperboard }\end{array}$ & 432.6 & 48.1 & 857.5 & 446.1 \\
\hline 9. & Plastics products & 498.2 & 250.9 & 36.9 & 262.0 \\
\hline & $\begin{array}{l}\text { Forging, pressing, stamping and roll-forming of } \\
\text { metal; powder metallurgy }\end{array}$ & 120.4 & 121.8 & 527.3 & 256.5 \\
\hline
\end{tabular}

33. The reason that pollution intensity is not captured in the shipbuilding sector itself is that this sector only captures the use of metal products, not the manufacture of the metals, which is much more pollution intensive. 
Among Hai Phong's top 10 polluting communes in terms of load, Ha Ly has only 4 firms but ranks highest among nearly all air pollutants (Table 2.12). These firms are pollution intensive. The cement, lime, and plaster sector accounts for 98 percent of the emissions to air (6.9 percent for land and
9.2 percent for water). The absolute level of air emissions is so high that it outweighs the impacts on land and water thus placing the sector in the top spot overall. The converse is true for the casting of iron and steel; it contributes 70 percent and 89 percent of land and water releases, respectively.

\section{Table 2.12. Hai Phong - ranking of top 10 communes with highest estimated pollution loads}

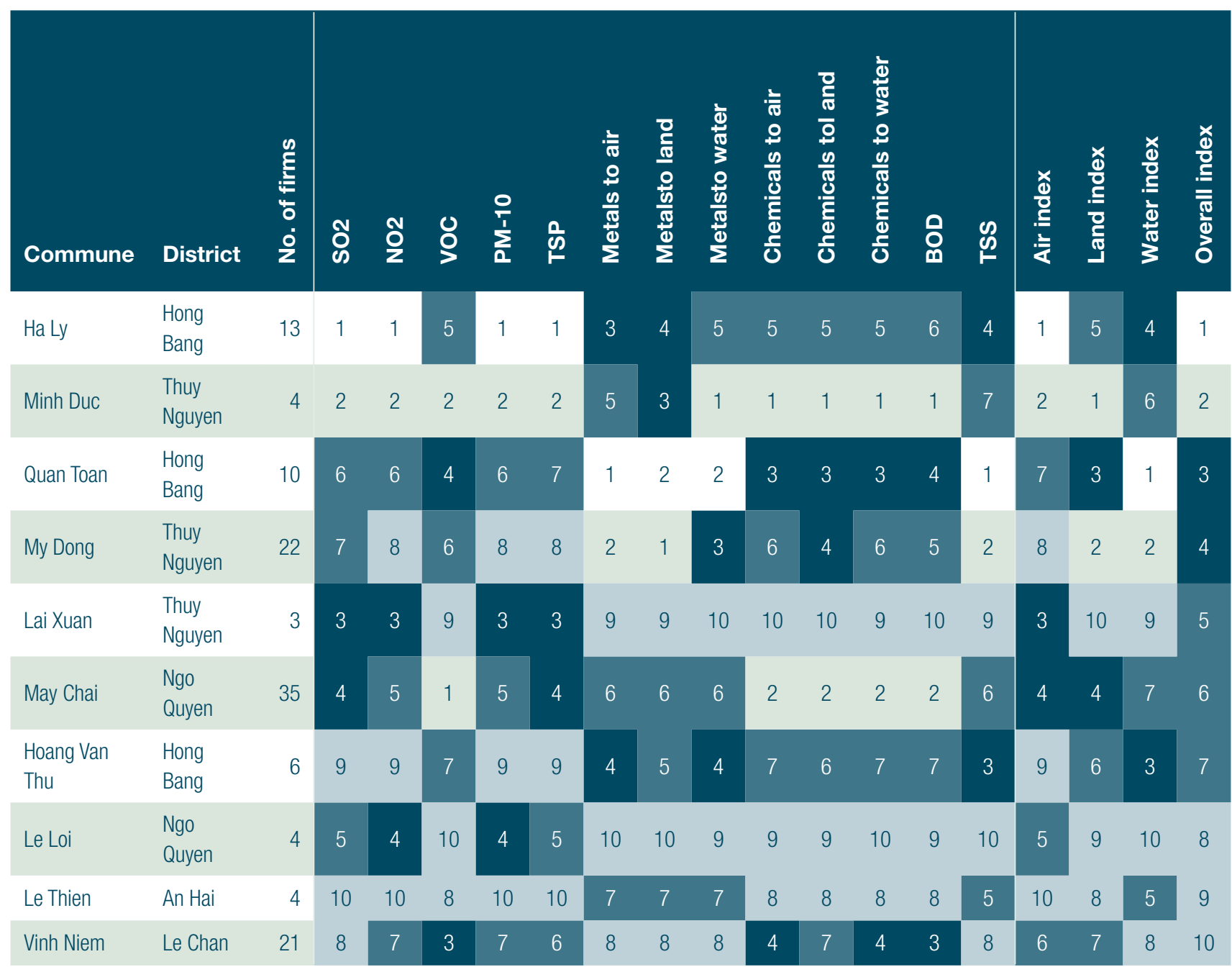

Note: The first quartile has no colored box (white/light green) to indicate that the sectors are the top quartile, the second quartile is colored dark blue, and the third is medium blue, and the fourth is light blue.

Source: Authors 


\section{(4) Binh Duong}

Binh Duong province is located in the southeast of Vietnam in the Southern Economic Focal Region and is crossed by the Saigon, Dong Nai, and Be rivers. The average GDP growth rate over the period 2001-2005 was 13-14 percent, nearly double that of the whole country. In the first half of 2004, the province had the second highest levels of foreign investment in Vietnam. Industry and construction were the fastest growing sectors, up 29-30 percent, whereas agriculture and forestry was 5.5-6 percent and services 12-13 percent. Binh Duong province's goal is to continue moving toward an economic structure reliant on industry and less on agriculture. As of 2005, GDP composition was 62 percent for industry, 28 percent for services, and 11 percent agriculture and forestry. There are 7 industrial zones in the south of the province with a total area of 1,500 hectares. The main focus of economic effort has been on the promotion of large-scale industries in the industrial zones with a 2010 goal of 13 additional parks.
Major sectors in the province include food processing, mechanical, chemicals, garments, shoes, leathers, and export industries. Traditional cottage industries also exist in pottery, construction materials, handicraft, fine arts, and lacquer wares, with the hopes of being able to promote these industries both in domestic and overseas markets. According to the 2004 GSO survey, the employment structure of the manufacturing sector reveals a diverse set of activities. Sectors that top the list in terms of employment (Table 2.13) include footwear (24 percent of total employment), furniture (17 percent), and wearing apparel (13 percent). The largest sectors in terms of number of firms also coincide with the largest employment shares. The furniture sector has 164 firms or nearly 12 percent of all firms in the province. One exception to this rule is the non-structural non-refractory ceramic ware sector with 139 firms and employing only 4.5 percent of workers. This is a reflection of the small cottage handicraft and ceramic industries in the North.

Table 2.13. Largest VSIC-4 manufacturing sectors in Binh Duong

\begin{tabular}{|c|c|c|c|c|c|}
\hline VSIC-4 & Manufacturing sector & No of workers & $\%$ & No of firms & $\%$ \\
\hline 1549 & Other food products n.e.c. & 6,345 & 2.0 & 30 & 2.1 \\
\hline 1810 & Wearing apparel, except fur apparel & 42,197 & 13.0 & 80 & 5.7 \\
\hline 1912 & Luggage, handbags, saddlery and harness & 10,322 & 3.2 & 15 & 1.1 \\
\hline 1920 & Footwear & 78,361 & 24.1 & 50 & 3.5 \\
\hline 2029 & Other products of wood; cork, straw and plaiting materials & 11,300 & 3.5 & 83 & 5.9 \\
\hline 2102 & Corrugated paper and paperboard, containers of paper and paperboard & 3,536 & 1.1 & 38 & 2.7 \\
\hline 2422 & Paints, varnishes and similar coatings, printing ink and mastics & 1,604 & 0.5 & 33 & 2.3 \\
\hline 2520 & Plastics products & 8,886 & 2.7 & 67 & 4.7 \\
\hline 2691 & Non-structural non-refractory ceramic ware & 14,747 & 4.5 & 139 & 9.8 \\
\hline 2693 & Structural non-refractory clay and ceramic products & 6,131 & 1.9 & 85 & 6.0 \\
\hline 2899 & Other fabricated metal products n.e.c. & 4,132 & 1.3 & 45 & 3.2 \\
\hline 3610 & Furniture & 54,028 & 16.6 & 164 & 11.6 \\
\hline \multirow[t]{3}{*}{3699} & Other manufacturing n.e.c. & 3,741 & 1.2 & 31 & 2.2 \\
\hline & Total of largest sectors & 245,330 & 75.6 & 860 & 60.8 \\
\hline & Total in Binh Duong & 325,238 & 100 & 1,414 & 100 \\
\hline
\end{tabular}

Note: Listing based on those sectors contributing 2 percent or more to employment or on number of firms in the province.

Source: Authors. 
The footwear sector appears as a major contributor across all 3 media. The furniture sector is also significant for air and land pollution loads as are ceramic products in general. In terms of overall pollution load, the plastics products and treatment and coating of metal/mechanical engineering sectors span all media. Mechanical engineering was identified as a major sector in the province and is a highly pollution-intensive sector. Ranking top sectors in the province according to overall air, land, and water indexes, the corrugated paper and paperboard sector, with only 38 firms, is the top sector owing to its large contribution to air and water releases (Table 2.14). Likewise a familiar top sector pattern emerges for the footwear, plastic products, and furniture sectors.

Table 2.14. Main polluting manufacturing sectors in Binh Duong VSIC-4 sectors contributing more than $5 \%$ to a pollutant to air, land and water*

Air

\Basic iron and steel

Basic precious and non-ferrous metals

$\nabla$ Cement, lime and plaster

\ Corrugated paper and paperboard, containers of paper and paperboard

$\otimes$ Processing and preserving of fish and fish products

\ Footwear

\ Furniture

$\triangle$ Plastics products

\ Pulp, paper and paperboard

$\nabla$ Refractory ceramic products

$\otimes$ Structural non-refractory clay and ceramic products

$\bigotimes$ Treatment and coating of metals; general mechanical engineering

\ Veneer sheets; plywood, laminboard, particle board, other panels and boards

凶 Wearing apparel, except fur apparel

Land

Water

$\boldsymbol{}$ Basic iron and steel

$\nabla$ Basic precious and non-ferrous metals

$\triangle$ Footwear

\ Forging, pressing, stamping and roll-forming of metal; powder metallurgy

Q Furniture

Q Non-structural non-refractory ceramic ware

$\nabla$ Other chemical products n.e.c.

$\triangle$ Plastics products

\ Treatment and coating of metals; general mechanical engineering
囚 Corrugated paper and paperboard, containers of paper and paperboard

$\otimes$ Basic iron and steel

$\nabla$ Dairy products

叉 Fertilizers and nitrogen compounds

$\triangle$ Footwear

\ Forging, pressing, stamping and roll-forming of metal; powder metallurgy

\ Other chemical products n.e.c.

\ Plastics products

\ Pulp, paper and paperboard

$\triangle$ Treatment and coating of metals; general mechanical engineering

囚 Veneer sheets; plywood, laminboard, particle board, other panels and boards

* More than 5 percent to any of the following pollution parameters within the provinces: Air - $\mathrm{SO}_{2}, \mathrm{NO}_{2}, \mathrm{VOC}, \mathrm{PM}-10$, TSP, metals, chemicals; Land — metals, chemicals; Water — BOD, TSS, metals, chemicals.

Source: Authors 
From the commune perspective, Table 2.15 shows that Di An is ranked as the top polluter across air pollutants but even more so across metals and chemicals. Binh Hoa is a close second with slightly lower ranking in the release of metals. These 2 communes represent the highest shares of employment as well, making them particularly dynamic. Disaggregating Di An to the level of sector activity pollution is not necessarily found in a few sectors. In Di An, even though the basic iron and steel sector is ranked highest in terms of everall load, its relative contribution for air is only 4.6 percent, 8.6 percent for land, and nearly 30 percent for water. Thus the high water loadings are what make this sector first in the ranking. In fact, the overall water index appears to drive many of the results for the top polluting communes. Each ranges from 6-30 percent of total provincial load, whereas much smaller shares are found for air and land.

\section{Table 2.15. Binh duong - ranking of top 10 communes with highest estimated pollution loads}

\begin{tabular}{|c|c|c|c|c|c|c|c|c|c|c|c|c|c|c|c|c|c|c|c|}
\hline Commune & District & 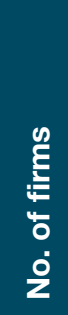 & ชิ & $\frac{\mathrm{q}}{\mathrm{z}}$ & 8 & $\frac{0}{\frac{0}{2}}$ & की & 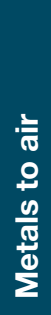 & 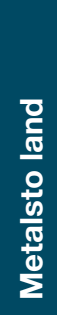 & 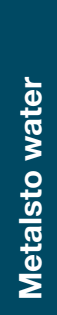 & 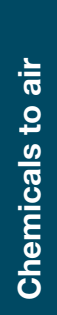 & 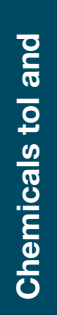 & 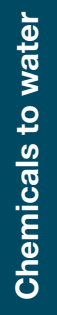 & ด & $\stackrel{p}{\mathscr{P}}$ & $\frac{x}{\frac{0}{0}}$ & 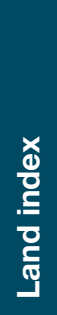 & 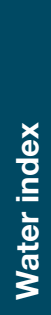 & 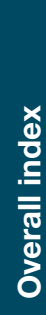 \\
\hline Di An & Thuan An & 160 & 2 & 3 & 2 & 1 & 2 & 1 & 1 & 1 & 2 & 1 & 3 & 3 & 1 & 2 & 1 & 1 & 1 \\
\hline Binh Hoa & Thuan An & 205 & 1 & 1 & 1 & 2 & 1 & 2 & 2 & 2 & 1 & 2 & 1 & 1 & 2 & 1 & 2 & 2 & 2 \\
\hline Thuan Giao & Thuan An & 153 & 3 & 2 & 3 & 6 & 3 & 6 & 5 & 3 & 3 & 3 & 2 & 2 & 4 & 3 & 3 & 3 & 3 \\
\hline Tan Dong Hiep & Thuan An & 72 & 5 & 5 & 6 & 5 & 5 & 3 & 3 & 4 & 6 & 6 & 7 & 6 & 3 & 5 & 5 & 4 & 4 \\
\hline An Phu & Thuan An & 82 & 4 & 4 & 4 & 4 & 4 & 8 & 8 & 5 & 4 & 4 & 4 & 4 & 7 & 4 & 6 & 6 & 5 \\
\hline Binh Chuan & Thuan An & 94 & 6 & 6 & 5 & 8 & 6 & 4 & 4 & 6 & 5 & 5 & 6 & 8 & 6 & 6 & 4 & 7 & 6 \\
\hline Tan Dinh & Ben Cat & 21 & 10 & 10 & 9 & 9 & 10 & 5 & 6 & 7 & 9 & 8 & 9 & 9 & 5 & 10 & 8 & 5 & 7 \\
\hline An Binh & Tan Uyen & 32 & 8 & 8 & 7 & 7 & 8 & 7 & 9 & 8 & 7 & 7 & 8 & 5 & 8 & 7 & 7 & 8 & 8 \\
\hline Phu Hoa & Thu Dau Mot & 29 & 9 & 7 & 10 & 10 & 7 & 10 & 10 & 9 & 10 & 9 & 5 & 7 & 9 & 9 & 10 & 9 & 9 \\
\hline An Thanh & Thuan An & 15 & 7 & 9 & 8 & 3 & 9 & 9 & 7 & 10 & 8 & 10 & 10 & 10 & 10 & 8 & 9 & 10 & 10 \\
\hline
\end{tabular}

Note: The first quartile has no colored box (white/light green) to indicate that the sectors are the top quartile, the second quartile is colored dark blue, and the third is medium blue, and the fourth is light blue.

Source: Authors 


\section{(5) Dong Nai}

Dong Nai Province is in the south of Vietnam and is an industrial province that has experienced heavy investment from foreign interests in the shipping, food products, and manufacturing industries. Dong Nai is rapidly modernizing; because of proximity to Ho Chi Minh City as well as a relatively well-developed infrastructure, commerce has thrived in the province. Farm-produce processing, electricity, electronics, mechanics, textiles and garments, footwear, construction material, woodwork, and handicraft production industries are booming. Under the 5-year plan (2006-2010), Dong Nai will focus on continued growth from the industry and construction sector and from the service sector while reducing agriculture's share of GDP to about 5 percent. Accordingly, industry and construction is maintaining a 57 percent share with services in the range of 38 percent. In 2005, Dong Nai's industry had a production value of over VND 42,476 billion, up 21 percent over 2004 and 5.6 percent above target growth. Industrial growth has been much higher than the national average as well as higher than the growth of other cities and provinces, such as Ho Chi Minh City, Hanoi, Hai Phong, and Ba RiaVung Tau. This increase was primarily a result of an increase in revenues from central state-owned enterprises of 11.2 percent, the local state-owned enterprises of 15.7 percent, the non-State enterprises of 23.9 percent, and foreigninvested companies of 23.5 percent. This growth is also reflected in a number of sectors highlighted as key to the overall development strategy of Dong Nai.

From the 2004 GSO data, manufacturing employment is diversified across a great number of sectors, particularly in the footwear sector with 33 percent (the largest total employment figure) and wearing apparel with 11 percent. Such sectors as the manufacture of electric motors, generators and transformers, and furniture also significantly contribute to the economy and were identified as areas of focused growth in the future planning periods. There are 2 sectors that are of primary concern as they are consistently listed as having more than 5 percent of the total provincial load - footwear sector and forging, pressing, stamping, and roll-forming of metal, powder metallurgy sector. Combining this information with that on total loads the footwear sector is the highest in terms of overall pollution. However, this is due to its very high load to land, rather than air or water. In fact, it is ranked $3^{\text {rd }}$ for air pollution and $4^{\text {th }}$ for water pollution. Forging, pressing, stamping, and roll-forming of metal, powder metallurgy is the other sector that crossed all 3 media in terms of its relative contribution. It is ranked $6^{\text {th }}$ among all sectors and this result is mostly driven by the water pollution load (ranked $3^{\text {rd }}$. The $3^{\text {rd }}$ ranked vegetable and animal oils and fats sector is the top polluter in terms of air emissions; and veneer sheets, plywood, laminboard, particle board, and other panels and boards is dominant in water pollution.

Within the province of Dong Nai, pollution tends to be concentrated among a small number of communes, in particular An Binh and Long Binh (Table 2.16). An Binh is ranked $1^{\text {st }}$ overall and with respect to air and $2^{\text {nd }}$ with respect to land and water. Air emissions in An Binh are so much greater than in Long Binh that it outweighs its $2^{\text {nd }}$ ranking for land and water. Looking at pollutant columns in Table 2.16, An Binh ranks highest among the variety of air pollutants but less than $1^{\text {st }}$ among chemicals and metals. In contrast, Long Binh is $1^{\text {st }}$ among chemicals and metals, which place it $2^{\text {nd }}$ overall. 
Table 2.16. Dong Nai - Ranking of top 10 communes with highest estimated pollution loads

\begin{tabular}{|c|c|c|c|c|c|c|c|c|c|c|c|c|c|c|c|c|c|c|c|}
\hline Commune & District & $\begin{array}{l}\frac{0}{E} \\
\frac{E}{6} \\
\frac{1}{0} \\
\frac{0}{2}\end{array}$ & ชิ & $\frac{\mathbf{y}}{z}$ & 8 & $\frac{0}{\frac{1}{2}}$ & $\frac{\Omega}{\mathscr{n}}$ & 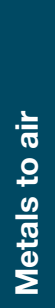 & 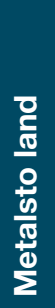 & 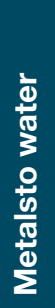 & 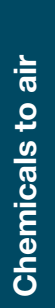 & $\begin{array}{l}\frac{0}{10} \\
\frac{0}{9} \\
\frac{0}{70} \\
\frac{0}{0} \\
\frac{0}{0}\end{array}$ & 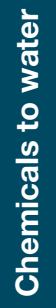 & อ & $\stackrel{\leftrightarrow}{\mathscr{R}}$ & 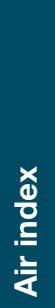 & 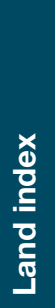 & 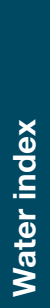 & 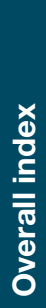 \\
\hline An Binh & Bien Hoa & 74 & 1 & 1 & 2 & 1 & 1 & 2 & 2 & 2 & 5 & 2 & 2 & 1 & 2 & 1 & 2 & 2 & 1 \\
\hline Long Binh & Bien Hoa & 119 & 2 & 2 & 1 & 3 & 2 & 1 & 1 & 1 & 1 & 1 & 1 & 2 & 1 & 2 & 1 & 1 & 2 \\
\hline Phuoc Thien & Nhon Trach & 45 & 3 & 3 & 4 & 2 & 3 & 4 & 4 & 5 & 4 & 5 & 5 & 7 & 8 & 3 & 5 & 8 & 3 \\
\hline Long Binh Tan & Bien Hoa & 36 & 4 & 5 & 3 & 5 & 5 & 3 & 3 & 3 & 2 & 3 & 4 & 4 & 4 & 4 & 3 & 4 & 4 \\
\hline Hoa An & Bien Hoa & 19 & 8 & 4 & 6 & 4 & 4 & 5 & 5 & 6 & 3 & 7 & 10 & 6 & 9 & 5 & 6 & 9 & 5 \\
\hline Phuoc Thai & Long Thanh & 17 & 6 & 6 & 8 & 6 & 6 & 8 & 6 & 4 & 9 & 4 & 3 & 10 & 5 & 6 & 4 & 5 & 6 \\
\hline Thong Nhat & Bien Hoa & 5 & 5 & 8 & 10 & 10 & 10 & 10 & 10 & 10 & 10 & 10 & 6 & 3 & 3 & 10 & 10 & 3 & 7 \\
\hline Thanh Phu & Vinh Cuu & 10 & 9 & 10 & 9 & 8 & 8 & 7 & 9 & 7 & 8 & 8 & 7 & 5 & 6 & 9 & 8 & 6 & 8 \\
\hline Ho Nai 3 & Thong Nhat & 59 & 7 & 7 & 5 & 9 & 9 & 9 & 7 & 8 & 7 & 6 & 8 & 8 & 10 & 7 & 7 & 10 & 9 \\
\hline Bac Son & Thong Nhat & 21 & 10 & 9 & 7 & 7 & 7 & 6 & 8 & 9 & 6 & 9 & 9 & 9 & 7 & 8 & 9 & 7 & 10 \\
\hline
\end{tabular}

Note: The first quartile has no colored box to indicate that the sectors are the top quartile, the second quartile is colored dark blue, and the third is medium blue, and the fourth is light blue.

Source: Authors

\section{B. Economic Focal Regions}

The following alternative perspective has relevance for government authorities interested in an area-based approach beyond that of the provincial level. The targeted and rapid economic growth and investment in the 3 economic focal regions is translating into growing pollution problems for these regions, and special management attention and collaboration from adjoining provinces. ${ }^{33}$ For each of the 3 economic focal regions, estimated air, land, and water pollution loads are ranked in order of priority with firm and employment figures for a select number of key polluting sectors

\section{(1) Northern Economic Focal Region}

Air pollution. Hai Duong and Hai Phong contribute the largest share of $\mathrm{SO}_{2}, \mathrm{NO}_{2}, \mathrm{PM}-10$ and TSP emissions in the Northern Economic Focal Region. Hanoi has 46.7 percent of

33. Northern provinces include Ha Noi, Quang Ninh, Vinh Phuc, Bac Ninh, Ha Tay, Hai Duong, Hai Phong and Hung Yen; Central provinces include Thua Thien Hue, Da Nang, Quang Nam, Quang Ngai and Binh Dinh; Southern provinces include Binh Phuoc, Tay Ninh, Binh Duong, Dong Nai, Ba Ria Vung Tau, Ho Chi Minh city and Long An. 
all VOC emissions, and Hanoi and Hai Phong together account for 72.5 percent of chemicals and for 68.6 percent of metals released to the atmosphere in this region. The cement, lime, and plaster sector is the single largest contributor of air pollution with 66.2 percent of $\mathrm{SO}_{2}, 46.9$ percent of $\mathrm{NO}_{2}, 56.0$ percent of TSP, and 86.6 percent of PM-10. No other industrial sector comes close to contributing as much of those 4 pollutants in the Northern Economic Focal Region. Yet, the sector has only 39 of the 5,163 firms in the region. Various subsectors contribute to VOC emissions - motorcycles (19.7 percent), plastic products (11.6 percent), and footwear (8.4 percent). A large number of additional subsectors release smaller shares of VOC emissions. The footwear subsector accounts for 19.6 percent of all releases of chemicals to the atmosphere, and the plastics sector for 14.3 percent. Basic iron and steel, casting of non-ferrous metals, and casting of iron and steel together account for 40 percent of all releases of metals to the atmosphere. These sectors have 167 enterprises in the Northern Economic Focal Region.

Hanoi and Hai Phong are the largest contributors of air pollutants in the region. In Hai Phong, the cement, lime and plaster sector contributes more than 50 percent of $\mathrm{SO}_{2}(66.9$ percent), $\mathrm{NO}_{2}$ (63.2 percent), $\mathrm{PM}-10$ (87.2 percent), and TSP (67.3 percent). The GSO 2004 Census reports 9 enterprises in this sector located in Hai Phong province, employing 3,232 people. The footwear sector is the largest contributor of VOC (26.1 percent) and chemicals (45.2 percent). The casting of iron and steel sector accounts for 25 percent of all metal releases to air in the province. In Hanoi, the structural nonrefractory clay and ceramic products is the most significant contributor of $\mathrm{NO}_{2}$ (33.6 percent), $\mathrm{PM}-10$ (26.3 percent), and TSP (47.2 percent) while plastics products contributes 21.4 percent of chemical releases to the air.

Water pollution. Hanoi and Hai Phong contribute most BOD (63.3 percent), TSS (68.3 percent), metal (73.6 percent), and chemical (73.6 percent) releases to water in the Northern Economic Focal Region. Hanoi alone has 41.2 percent of BOD, 43.9 percent of metals, and 47.3 percent of all emissions from manufacturing in the region. In terms of contribution by industrial sectors, the basic chemicals sector accounts for 27.6 percent of chemical and 17.6 percent of metal releases despite having fewer than 0.5 percent of all industrial firms and employment (20 enterprises and 2,163 labor) in the
Northern Economic Focal Region. Basic iron and steel is also a large contributor of metals (13.6 percent) but is especially significant for TSS releases (29.6 percent). The casting of iron and steel sector accounts for an additional 19.6 percent of TSS emissions. Those 2 sectors have fewer than 160 of the 5,163 enterprises in the region. Together corrugated paper and paperboard sector and the pulp, paper, and paperboard sector contribute 41.8 percent of BOD from 165 enterprises. Within Hanoi and Hai Phong, the corrugated paper and paperboard sector is the largest contributor of BOD. In Hanoi, TSS comes mostly from the basic iron and steel sector (33.6 percent) while in Hai Phong the largest contributor of TSS is the casting of iron and steel (44.2 percent). With 8 enterprises in Hai Phong, the basic chemicals, except fertilizers and nitrogen compounds sector produces 54.7 percent of all chemical releases to water.

Land pollution. Hanoi and Hai Phong contribute the largest share of chemicals (74.7 percent) and metals (68.9 percent) released to land in the Northern Economic Focal Region. Hanoi alone accounts for 46.9 percent of chemical releases to land and the basic iron and steel and casting of iron and steel sectors account for 34.4 percent of metal releases. The basic chemicals sector, except fertilizer and nitrogen compounds sector, is the single largest contributor of chemical releases to land (21.3 percent) from only 20 enterprises.

\section{(2) Central Economic Focal Region}

Air pollution. Thua Thien Hue and Da Nang contribute the largest share of $\mathrm{SO}_{2}, \mathrm{NO}_{2}, \mathrm{PM}-10$, and TSP in the Central Economic Focal Region. Binh Dinh is also a significant contributor of VOC. Binh Dinh and Da Nang together account for 77 percent of chemicals released to the atmosphere, and Da Nang alone contributes 53.7 percent of all metal releases to air in the region.

In terms of contribution by industrial sectors in the Central Economic Focal Region, the cement, lime and plaster sector is the single largest contributor of air pollution releases (except for $\mathrm{VOC}$ ) with 51.9 percent of $\mathrm{SO}_{2}, 40.1$ percent of $\mathrm{NO}_{2}, 37.6$ percent of TSP, and 69.4 percent of PM-10. The sector has only 7 of the 894 firms in the region. Most VOC emissions in the region come from two subsectors, furniture (22.2 percent) and processing and preserving of fish and fish products (24.3 
percent). A large number of other subsectors contribute smaller shares of VOC emissions. The furniture subsector accounts for 28.4 percent of chemical releases and basic iron and steel for 27.2 percent of metal releases to the atmosphere. Within Da Nang, the cement, lime, and plaster sector with only 3 enterprises and the processing and preserving of fish and fish products sector with 14 enterprises together release 68.2 percent of $\mathrm{SO}_{2}, 49.6$ percent of $\mathrm{NO}_{2}, 77.8$ percent of TSP, and 91.6 percent of PM-10.

Water pollution. Da Nang and Binh Dinh contribute most water pollutants in the Central Economic Focal Region (59 percent of BOD, 68.3 percent of TSS, 63 percent of chemicals, and 70.3 percent of metals). Da Nang alone accounts for 54.4 percent of all emissions of TSS. In terms of contribution by industrial sectors in the Central Economic Focal Region, the fertilizer and nitrogen compounds sector accounts for 26.1 percent and 21.7 percent of chemical and metal releases, respectively. The corrugated paper and paperboard sector releases 31.8 percent of BOD, and the basic iron and steel sector contributes 33.4 percent of TSS in the region. Those three sectors together have only 53 enterprises of the total in the Central Economic Focal Region.

Land pollution. Da Nang accounts for 42.6 percent and 51.7 percent of all releases of chemicals and metals to land in the Central Economic Focal Region with Binh Dinh contributing an additional 24.8 percent of chemical and 14.6 percent of metal releases in the region. The fertilizer and nitrogen compounds sector accounts for 23 percent of chemical releases and the processing and preserving of fish and fish products sector an additional 20 percent to this load. The basic iron and steel sector dominates in releases of metals (24.1 percent) in this region.

\section{(3) Southern Economic Focal Region}

Air pollution. Ho Chi Minh City contributes more than 50 percent of each air pollutant in the Southern Economic Focal Region. Binh Duong and Dong Nai fall well behind with the next most significant polluting loads. The Southern Economic Focal Region differs from the other two economic focal regions in having no single sector dominant for any given air pollutant (with the exception of PM-10), explained by the large variety of firms from all industrial sectors operating in the region. The single largest sources of $\mathrm{SO}_{2}$ are the cement, lime, and plaster sector and the processing and preserving of fish and fish products sector with 20.6 percent and 17.0 percent of emissions, respectively. The cement, lime, and plaster sector also contributes 42.1 percent of PM-10 with the processing and preserving of fish and fish products sector adding 26.2 percent of this pollutant. Together these two sectors release 43.1 percent of TSP emissions. The footwear sector contributes to 30.1 percent of all chemicals and 21.0 percent of all metals released to the atmosphere in the region. The plastic products sector is also a significant contributor of chemicals (15.9 percent) while the basic iron and steel sector contributes to 11.7 percent of metals released to the air.

Within Ho Chi Minh City, cement, lime, and plaster is the largest source of $\mathrm{SO}_{2}, \mathrm{NO}_{2}, \mathrm{PM}-10$, and TSP. There are 12 enterprises in this sector located in the province. The plastics products sector releases 20.7 percent of all VOC emissions in Ho Chi Minh City from 478 enterprises with a total of 35,045 employees. These enterprises are on average relatively small with an average of 73 employees. Footwear sector releases 18.6 percent of all metals and 27.2 percent of all chemicals to the air. This sector has 130 enterprises in Ho Chi Minh City, employing a total of 175,000 employees (i.e., on average 1,346 employees per plant).

Water pollution. Ho Chi Minh City contributes more than 50 percent of each water pollutant in the Southern Economic Focal Region, including 59.1 percent of chemicals and 56.8 percent of metals. Binh Duong and Dong Nai are the next most significant polluting sources in the region. In terms of contribution by industrial sectors, the Southern Economic Focal Region differs from the other two economic focal regions with no single sector dominating water pollution; a similar situation was found earlier with respect to air pollution. Collectively, the fertilizer and nitrogen compounds; basic chemicals, except fertilizer and nitrogen compound; plastics products; and corrugated paper and paperboard sectors contribute 55.1 percent of all chemical releases in the Southern Economic Focal Region. The release of metals is spread through numerous industrial sectors but corrugated paper and paperboard, dairy products, veneer sheets, and footwear sectors together release 68.3 percent of BOD. The basic iron and steel sector is the most significant contributor 
to TSS releases (22.8 percent) as it is at national level and in the other economic focal regions. In Ho Chi Minh City, dairy products are the most significant contributor to BOD (28.1 percent) from only 16 enterprises each with 335 employees on average. As is often the case, basic iron and steel is the largest contributor of TSS (26.6 percent).

Land pollution. Ho Chi Minh City contributes 57.2 percent of chemical and 52.5 percent of metal releases to land in the Southern Economic Focal Region. Binh Duong and Dong Nai together contribute an additional 31.5 percent of chemicals and 38.5 percent of all metals. These three provinces thus account for almost all releases of these forms of pollution in the Southern Economic Focal Region. Fertilizer and nitrogen compounds, basic chemicals, plastics products, and footwear represent 45.6 percent of chemical releases to land, while footwear and basic iron and steel contribute to 13.3 percent and 11.7 percent, respectively, of metal releases to land in the region.

For land pollution, unlike the situation for air and water, situations are not found at the provincial level where one or two sectors account for more than 50 percent of the chemical or metal releases. In Hanoi and Ho Chi Minh City, for example, it takes the top six most significant contributors to metal releases to land to reach 50 percent of total releases. This may prove to be important from a pollution control point of view since it implies that such releases of metals to land could not be significantly controlled and reduced by focusing pollution control effort on just one or two sectors.

\subsection{Summary}

Section 2 has outlined the pollution profile from a national, regional, provincial, and commune level of analysis. The purpose of taking this geographical perspective was to show that priorities can also be made according to the various spatial boundaries. Priorities can be set within these geographic units, identifying major sectors and pollutants that should be the focus of actions taken in the future.

Broadly speaking, at the national level Ho Chi Minh City, Hanoi, Binh Duong, Hai Phong, and Dong Nai represent the top 5 provinces according to the National Pollution Index constructed from profiles of air, land and water emissions. Within each of the provinces, a few communes were at the heart of pollution intensity. Pollution within the top communes also revealed a relative concentration of air, land, and water pollution load in a small number of sectors.

Table 2.5 summarizes the top 10 provinces according to the overall pollution indexes used throughout the report. It also identifies the top 10 communes where pollution is most acute. They carry a significant proportion of the provincial pollution load. The results are skewed the same in the sector results for each province. Quite often one or two sectors can be responsible for greater than 50 percent of the total load in a commune. These results show that regulation and control can be focused on a relatively small number of sectors within a small number of communes. Likewise, one may also focus on a subset of pollutants that are most responsible for the indexed load. 


\section{SECTION 3. INSTITUTIONAL AND REEULATORY FRAMEWORK}

Having learned from international experience on industrial pollution management, Vietnam has progressed rapidly through several stages at once. In the mid 1990s, pollution control measures targeted specific plants to begin clean up of existing industries. For the first time, national pollution standards were applied through environmental impact assessment (EIA) of new development projects. Since then, a process of decentralization and building of sectoral capacity in environmental management has jointly moved forward while the central environment authorities are still setting in place the basic elements for systems of pollution prevention and control. In less than ten years, Vietnam has passed quickly through developmental stages in industrial pollution management (IPM) institutions and policy reform that took other countries many more years to attain. Inevitably, the pace and scale of change has left capacities unfulfilled and gaps in the system. among which include:

- Government being both regulator and owner of industry most often through the same set of ministries;

- The large number of ministries involved as both industry regulators and ownners;

- An overriding emphasis on development and economic growth in the mandates of industry line ministries;

- Rapid decentralization to 64 provinces that lack funding, expertise, and incentives for rigorous application of industrial pollution management, and

- Rapidly changing and uncertain regulatory framework to manage and promote private enterprise.

Section 3 describes the role of Government in Vietnam as environment and industry manager and analyzes the evolving relationships between these two functions and of the responsibilities and capacities of the agencies concerned. It deals with the policy and institutional arrangements in relevant sectors and the achievements and remaining challenges in advancing the objectives of industrial pollution management, and sets out directions for change and innovation.

\subsection{The Institutional Framework}

The evolution of environmental institutional arrangements in Vietnam began during the mid-1980s with institutional reforms and the launching of a five-year national research program on environmental studies. 1993/4 saw the creation of the Ministry of Science, Technology and Environment (MOSTE) and its National Environment Protection Agency. In the following decade significant innovation in environment policy and management systems took place with an expanding provincial network of Departments of Science, Technology and Environment (DOSTE). In those years, the basic framework for pollution control, environmental impact assessment, and national monitoring and reporting were set in place. However, the policy, legislative, and institutional expansion and innovation moved well beyond the capacities of staff, budgets, and structures to manage effectively, especially at local level.

Controlling pollution and managing natural resources are inextricably linked. Good environmental management decisions and good natural resource management decisions are central to dealing with pollution. This complicates the institutional arrangements for pollution control and management. In Vietnam these responsibilities are spread between the 'environment' part of the Ministry of Nature Resources and the Environment (MONRE) - Vietnam Environmental Protection Agency, Department of Environment, Department of Environmental Impact Assessment and Appraisal (DEIAA) - and the Department of Water Resources Management, which is implementing key aspects of pollution control in relation to water. Many may see this as a perceived weakness. However, the development and implementation of a strong and strategic framework for pollution control in Vietnam is at its early stages. As this matures and develops, and as its focus changes from the control of single-point sources of pollution to control of all forms of pollution at the enterprise level, institutional responsibilities will also evolve to reflect these changing requirements.

For the immediate future, the most critical issue is to build on the fact that all environment organizations are within the one Ministry and to strengthen the integration and cooperation among them. The current system does provide strong incentives for building working relations with decentralized institutions at local-level government. But there are few similar incentives to promote lateral relations, for example, between MONRE core environment organizations and the various sectoral ministries responsible for managing industries. 


\section{A. Establishment of Ministry of Natural Resources and Environment}

Ministry of Natural Resources and Environment was established to "direct and collaborate with ministries, branches, provinces in the management and regulation of the environment and its natural resources." 35 The initial proposal for establishing the Ministry of Natural Resources and Environment was put to a national conference on sustainable development in Vietnam in 1990. At that time three main reasons were debated for drawing together various functions of existing organizations into one Ministry: (a) The need for a single agency to manage and coordinate the nation's first comprehensive and integrated environment and development strategy; (b) to separate the state management and regulatory functions relating to natural resources from activities for their development and exploitation (a key principle of the Government's Public Administration Reform); ${ }^{36}$ and (c) to bring land, natural resources, and environment management functions under one roof to promote integration so that natural resource use (including land, minerals, water, and air) and environmental quality are managed according to one consistent system of allocation, safeguards, and conditions.

However, the Ministry of Natural Resources and Environment was established by Governmental Decree No. 91/2002/NDCP, of November 11, 2002. ${ }^{37}$ It incorporates: (a) the former
General Department of Land Administration; (b) the former General Department of Hydro and Meteorology; (c) the National Environment Agency of Vietnam under the former Ministry of Science, Technology, and Environment; (d) the Vietnam Department of Geology and Minerals and the Institute of Geology and Minerals (both transferred from Ministry of Industry); and (e) the section of water resources management previously attached to the former Department of Water Resources and Dyke Works Management under the Ministry of Agriculture and Rural Development (Figure 3.1). As such, the Ministry of Natural Resources and Environment is the Government's central pollution control organization and the main regulatory body for maintaining environmental quality nationwide, through the merging of units from other parts of government, each with their own structures and ways of working.

The Ministry and Departments of Natural Resources and Environment have been facing a period of expansion and deepening of environmental management responsibilities on a scale never before experienced in Vietnam. Every new environmental policy at national level needs to be expressed in practical terms in a myriad of ways affecting the operations of the Ministry of Natural Resources and Environment, the main line ministries, and local-level institutions. ${ }^{38}$

35. Governmental Decree No. 91/2002/ND-CP, November 11, 2002.

36. On September 17, 2003, Decision No. 136/2001/QD-TTg approved the Public Administration Reform Master Programme for the 2001-2010 period.

37. At the first session of its 9th Congress on August 5, 2002, the National Assembly passed Resolution No. 02/2002/QH11 listing the ministries and bodies of the Government, including the Ministry of Natural Resources and Environment.

38. Specifically, MONRE functions in the environmental field are to: (i) direct the implementation of regulations and measures for environmental protection and the prevention and relief of environmental degradation and pollution; (ii) administer the national environmental monitoring system; collect and process data, and periodically assess the condition of the environment and forecast significant changes; (iii) appraise reports on the environmental impacts of projects; (iv) formulate regulations on environmental standards and manage the granting and withdrawal of certificates in relation to their application; (v) mobilize financial support from state and other sources for environment protection, and manage the Environment Protection Fund of Vietnam; (vi) organize the implementation of plans for scientific research and its application for environmental protection; and, (vii) inspect and resolve complaints and violations of the legislation. On water resources, MONRE functions are to (among others) submit the assignments and devolvement for basic surveys and the authority to license water resources. 


\section{Figure 3.1. Structure of the Ministry of Natural Resources and the Environment}

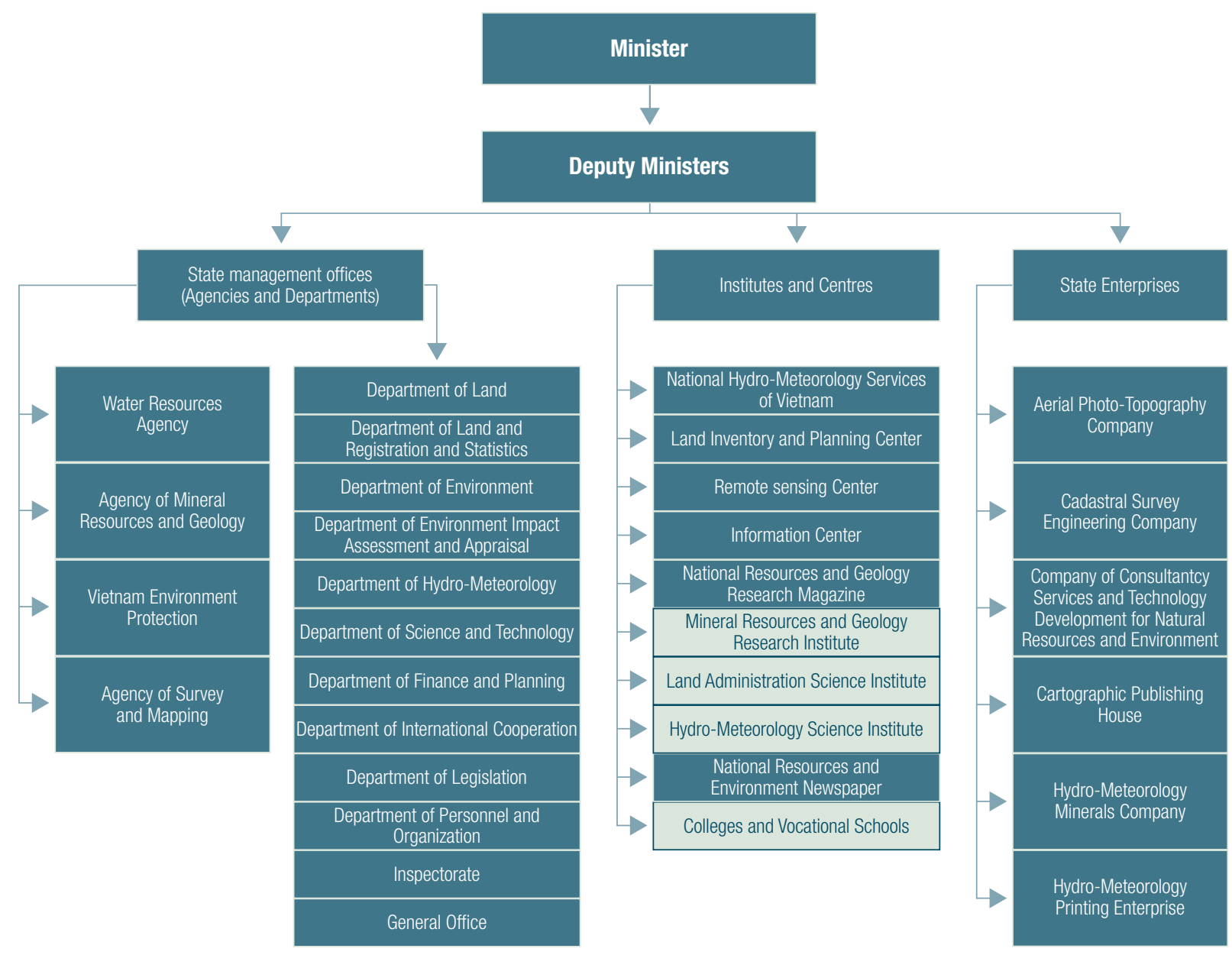

Source: MONRE 2007

50 Rural Development, Natural Resources and Environment Unit of the East Asia and Pacific Region 
The Ministry of Natural Resources and Environment is made up of 4 agencies (or Cuc), 12 departments (or Vu), 10 institutes and centers of various kinds, and 6 enterprises. The environment functions fall under a vice minister and 3 bodies - the Vietnam Environmental Protection Agency (VEPA), Department of Environment (DOE), and the Department of Environmental Impact Assessment and Appraisal (DEIAA). The establishment of provincial Departments of Natural Resources and Environment ${ }^{39}$ was expected to strengthen and improve the integration of land, environment, and water issues in their planning and delivery of services to the general public.

\section{B. Vietnam Environmental Protection Agency}

The Vietnam Environmental Protection Agency is the Government's main environmental protection body. The MONRE Minister established VEPA regulating powers, tasks, and responsibilities in 2002. ${ }^{40}$ The primary role is to support MONRE leadership in implementing state management over environmental activities, including pollution prevention, environmental quality improvement, nature conservation, environmental technology promotion, and enhancement of public awareness. In July 2004, the MONRE Minister amended VEPA responsibilities ${ }^{41}$ to move authority for conducting environmental inspection to the MONRE Environmental Inspectorate. Thus, Vietnam Environmental Protection Agency is only responsible for cooperating with the Environmental Inspectorate to conduct environmental inspections and settle environment-related disputes, complaints, and violations. Specific VEPA duties and powers relevant to industrial pollution management include:

- Investigating and assessing environment quality at serious degraded and polluted areas on land and sea and recommending solutions for environment protection;

- Inspections on environment, conflict resolution and settlement of complaints, enforcement and supervision of environment protection regulations, and controlling and managing waste;

- Managing the national environment monitoring network and environment monitoring stations;

- Organizing research, promoting technology innovation in pollution prevention, environment protection, waste treatment and recycling, environment enhancement and ecosystem rehabilitation, ecological industrial zones, and cleaner production; and

- Coordinating the management of the Vietnam Environmental Protection Fund.

39. The Departments commenced in 2003 through Decision No. 45/2003/QD-TTg of the Prime Minister, and Circular No. 01/TTLT-BTNMT-BNV of July 15, 2003 jointly issued by MONRE and the Ministry of Home Affairs providing guidelines for DONRE functions, powers, and structure.

40. Ministerial Decision No. 108/2002/QD-BTNMT,,December 31, 2002.

41. Ministerial Decision No. 15/2004/QD-BTNMT, July5 2004. 


\section{VIETNAM ENVIRONMENT PROTECTION AGENCY}

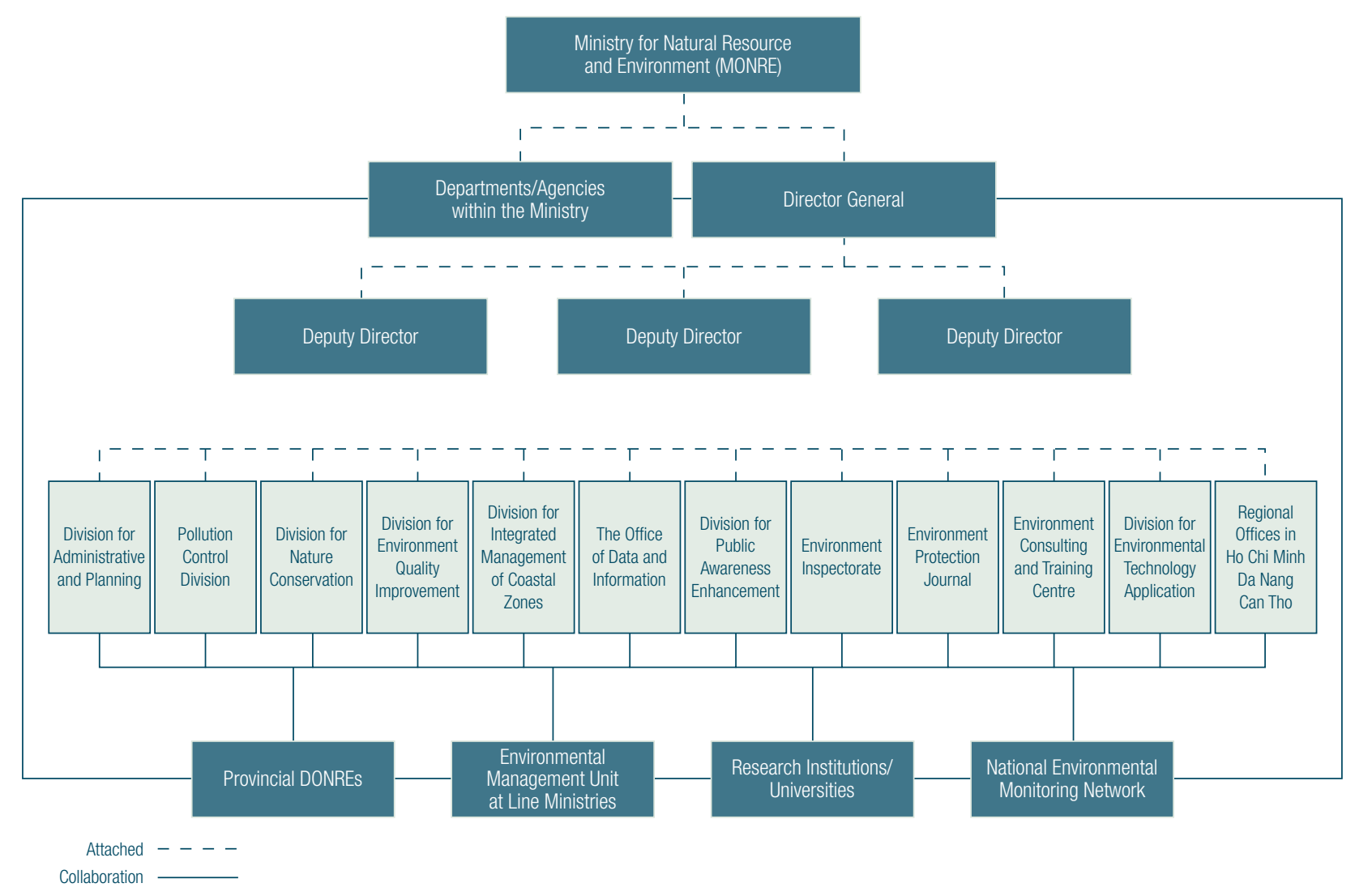

Source: VEPA 2007 


\section{Department of Environment}

The Department of Environment ${ }^{42}$ supports the MONRE Minister in environmental policy-making and the development of related legislation, strategies, and plans. Setting policy is the primary focus of the Department. Its responsibilities range from the development of new laws and implementation of decrees and regulations to coordinating the preparation of environment strategies and action plans. It has an evolving function in the testing and use of economic instruments to achieve environmental management objectives. There is growing potential for uncertainty and overlap in the distinctive roles between the Department of Environment and Vietnam Environmental Protection Agency on matters of policy and regulation.

\section{Department of Environmental Impact Assessment and Appraisal}

The Department of Environmental Impact Assessment and Appraisal ${ }^{43}$ is responsible for the state management of environmental impact assessment and appraisal of plans and projects at the national level. ${ }^{44}$ With the passage of the Amended Law on Environmental Protection and its Strategic Environmental Assessment (SEA) provisions, DEIAA function and work load has greatly expanded. Under the Amended Law for Environmental Protection (ALEP), the Strategic Environmental Assessment is mandatory for a wide range of strategies, long-term general plans, and short-term specific plans on national, inter-provincial, and provincial levels. This represents a far-reaching change from previous practice focusing on individual projects and holds considerable promise for integrating or mainstreaming environment into earlier stages of decisionmaking. However, SEA awareness, understanding, and capacity are weak in line ministries and in the Ministry of Natural Resources and Environment. The DEIAA is contributing to an implementing decree for the ALEP and taking the lead in preparing SEA guidelines. In 2005, there was a significant adjustment to MONRE allocation of EIA duties with transfer of the EIA appraisal function to the Vietnam Environmental Protection Agency, effectively narrowing the DEIAA role to the development and supervision of regulatory frameworks and technical guidelines for environmental impact assessment. ${ }^{45}$

\section{E. The MONRE Inspectorate}

The MONRE Inspectorate ${ }^{46}$ belongs to the State Inspectorate and is responsible for performing environmental inspections and managing professional inspections conducted by subordinate agencies. The MONRE Inspectorate has legal authority to ensure compliance of state agencies, socialeconomic organizations, and citizens within its jurisdiction and apply penalties to noncompliance. The Inspectorate has a potential but unclear role with respect to the enforcement of environmental laws and regulations. It has been given the mandate of "inspecting the compliance with policies and legislation by State management agencies, socio-economic organizations and citizens for the fields of the Ministry's State management, and dealing with infringements in accordance with the provisions stipulated by the law".

Originally, the MONRE Inspectorate focused on its internal review functions "to inspect the implementation of policies,

42. Ministerial Decision No. 109/2002/QD-BTNMT, December 31, 2002.

43. Ministerial Decision No 111/2002/QD-BTNMT, December 31, 2002.

44. Decree No. 143/2004/ND-CP of July 12, 2004 Amending and Supplementing Article 14 of Decree No. 175/CP of October 18, 1994.

45. Specific DEIAA tasks and powers are to: draft legislative documents regarding EIA and appraisal; provide guidelines for and supervise their implementation; organize all necessary activities to appraise EIA strategies and reports of projects as decentralized; supervise the implementation of environmental protection activities as committed in appraised EIA reports from commencement to completion of projects and propose solutions as required; organize appraisal of EIA reports of special development projects without a specific owner in special economic zones and catchment areas; organize appraisal of EIA of environmental technologies, the facilities to treat wastes which are manufactured and/or assembled in the country or those imported into Vietnam; organize EIA appraisal of the use of wastes as input for production and the using of the products derived from wastes; respond to individuals and/or organizations on issues related to EIA as requested; provide guidelines and professional training in the fields of EIA and appraisal; and implement international programs and projects and scientific studies in the fields of EIA and appraisal.

46. Ministerial Decision No. 61/2002/QD-BTNMT, December 25, 2002. 
legislation and duties by units and individuals under the Ministry." However, a significant development was the announcement in late 2006 of the establishment of an Environmental Police Department to handle inspection and propose administrative punishments, such as fines for environmental violations. ${ }^{47}$ The environment police would be deployed first in large cities and industrial areas where most violations are reported. Initially, the new Environmental Police Force will not have adequate numbers, therefore the main inspection and enforcement duties will be delegated to local police and constabulary police. For serious environmental violations, such as discarding toxic garbage, radioactive waste, or polluting the environment in a harmful way, an Environmental Crimes Investigation Unit will be set up under the current Crimes Investigation Police Agency. The Ministry of Public Security will list and classify levels of offense as well as consult with related branches to standardize case-by-case punishment. Over the past five years, the Police Agency found 26,540 cases violating the Law on Environmental Protection, most relating to the over-exploitation of forest resources, air, and land pollution, and importing of out-of-date technology. The Ministry of Natural Resources and Environment has made the establishment of the Environmental Police Department a priority project for 2007, with force training to come from the Ministry of Public Security. The working relationships among the new Environmental Police Department, Vietnam Environmental Protection Agency, and Departments of Natural Resources and Environment in overall pollution management will be an important issue to work through.

\section{F. Industrial Park Management Boards}

The institutional framework for overall development and management of Industrial Parks, Export-Processing Zones was established in 1997.48 Roles and responsibilities for environmental protection planning, management and reporting are clearly detailed in the implementing Regulation on Industrial Parks Environmental Protection. ${ }^{49}$ Generally, the performance of the Industrial Park Management Boards in reducing and controlling pollution has not matched their zeal for expansion. The vast majority of industrial parks in Vietnam, including many of those recently established, have no or inadequately installed capacity and management systems for pollution prevention and control. Many of the few equipped industrial parks sporadically operate such equipment or not at all, and are noncompliant with their EIA approvals and pollution prevention and control permits and licenses. The Departments of Natural Resources and Environment have no direct authority for pollution regulation within industrial parks.

\section{G. Decentralization of Environmental Management}

The 3rd Plenum of Term VIII of the Party's Central Committee in June 1997 decided that "based on the united management of central State of institutions, and of strategies and plans for development of all sectors and the national economy, it is necessary to decentralize clearly and reasonably administrative responsibilities and competencies to facilitate and increase the autonomy of local governments, exploring all potentials for local social and economic development." In a 2005 internal review, the Ministry of Natural Resources and Environment found that the legal basis for the decentralization of environmental protection functions is adequate. In 2005, the Ministry of Natural Resources and Environment submitted to the Government of Vietnam a program for "decentralization of state management of environmental protection." 50 The Government found that MONRE actions toward decentralization had been appropriate, taking into account progress in decentralization of strategies, plans, and implementation; environmental impact assessment and appraisal; the management of monitoring systems; state of environmental reporting; forecasting of environmental change; certification based on environmental standards and other environmental permissions; inspection, examination and supervision of environmental dispute resolution; and administrative punishments for violations on environmental protection. However, the MONRE statement also emphasized the need to develop and improve the capacity for environmental

47. VN Express Newswire (September 20, 2006), www.thanhniennews.com/society/?catid=3\&newsid=19050 48. Decree 36/CP, April 24, 1997, on the Regulation of Industrial Parks, Export-Processing Zones and Hi-Tech Parks. 49. Decision No. 62/2002/QD-BKHCNMT, August 9, 2002. Regulation on Industrial Park Environmental Protection. 50. Statement No. 17/TTr-BTNMT, May 20, 2005. 
management in ministries, sectors, local areas, industrial zones, and export processing zones. In this section the key steps in decentralizing environmental management functions are reviewed.

The provincial Departments of Natural Resources and Environment were established and former Departments of Science, Technology and Environment renamed Departments of Science and Technology. ${ }^{51}$ The Departments of Natural Resources and Environment were formed by merging the former Department of Land Administration and organizations responsible for water and mineral resources and the environment belonging to the Department of Agriculture and Rural Developments, the Departments of Industry, and the former Departments of Science, Technology and Environment. The Ministry of Natural Resources and Environment and Ministry of Home Affairs issued several secondary legal instruments to guide local authorities in setting up the Departments of Natural Resources and Environment in provinces and the centrally run cities. By August 2005 all provinces had operational Departments, including the three newly separated provinces (Hau Giang, Dac Nong, and Dien Bien). In Hanoi, the functions of housing management have been added to create the Hanoi Department of Natural Resources, Environment and Housing.

The Ministry of Natural Resources and Environment and the Ministry of Internal Affairs issued a joint circular setting out the guiding powers, tasks, and organization of functional agencies that support Provincial Peoples Committees in managing state natural resources and the environment at the local level. ${ }^{52}$ Accordingly, the Departments of Natural Resources and Environment are agencies of the Provincial Peoples Committee, responsible for supporting the Provincial Peoples Committee in state management for issues related to land, water resources, minerals, environment, hydrometeorology, and mapping in the province, and reporting administratively to the national government. On technical matters, the Departments work with the Ministry of Natural Resources and Environment, but the establishment of functional divisions within the Departments of Natural Resources and Environment is decided by the Provincial Peoples Committees in consultation with the Ministry.

The Departments of Natural Resources and Environment are responsible for submitting to Provincial Peoples Committee any grants, extensions, and revocations of environmental certificates. However, the Chief Environmental Inspectorate of the Department of Natural Resources and Environment is empowered to revoke the environmental certificates in case of detected violations. ${ }^{53}$ The DONRE role includes conducting environmental compliance inspections, settling environmentalrelated disputes, compliance, and violations within its provincial jurisdiction. The DONRE Environmental Inspectorate may conduct both announced and unannounced inspections by itself or in cooperation with the MONRE Environmental Inspectorate. The DONRE Environmental Inspectorate must report to the Department of Natural Resources and Environment regarding the performance of its tasks and responsibilities but not to the MONRE Environmental Inspectorate. In addition to its inspection role, the Departments of Natural Resources and Environment evaluate environmental impact assessments submitted by regulated establishments and collect fees for environmental protection including those for wastewater.

There are 7 functional divisions under every Department of Natural Resources and Environment. One such division specializes in environment protection (normally called the Environmental Management Division). One of 3 semiindependent institutions (i.e with its own bank account and seal) under each Department is a Center for Environmental Monitoring. Already, 91 percent of Departments of Natural Resourcesand Environments have Environmental Management Divisions but only 17 percent have Centers for Environmental Monitoring. The Environmental Management Divisions work on environmental certification, environmental impact assessment, environmental monitoring, and the collection of environmental protection fees. In the natural resource area, a critical issue in relation to industrial pollution is that only 14

51. Government Decision No. 45/2003/QD-TTg, April 2, 2003.

52. Inter-Circular No. 01/2003/TTLT-BTNMT-BNV, July 15, 2003; and Circular No. 1694/2003/TTLT-BTNMT-TCCB, July 18, 2003.

53. Decree No. 121/ 2004/ND-CP. 
percent ofDepartments of Natural Resourcesand Environments have an established division for water management.

Though Environmental Management Divisions have been established in Departments of Natural Resources and Environments, the environmental background and capacity of staff working in these divisions is limited. Eighty-eight percent of DONRE directors are former directors or deputy directors of land administrative departments. Seventy-seven percent of DONRE deputy directors come from former land administration departments. Only two or three (or less than 2 percent) DONRE deputy directors had the same position in former Departments of Natural Resources and Environments. Many environmental management officers remained in the Departments of Science and Technology. In the natural resource area, few water resource staff transferred from the Departments of Agriculture and Rural Development to the new Departments of Natural Resources and Environments, leaving critical shortages in this area.

In 2004, the establishment of District Divisions of Natural Resources and Environment commenced by upgrading the former Divisions of Land Administration in 333 of the 594 districts nationwide. ${ }^{54}$ Progress continues in setting up of new Divisions of Natural Resources and Environment in other districts, but districts have found the overall task difficult given the low level of existing capacity and budgets. To date there are some 2,000 staff in place but few have benefited from any form of environmental or natural resource management training. At the communal level, staff (usually one or two) are assigned to land administration functions, paid from the governmental budget according to their qualifications. There are 10,674 cadastral staff in communes and wards. The strategy is to train those existing staff to take on the additional responsibilities for natural resources and environmental management.

The 2005 MONRE statement to Government concerning its decentralization program identified a wide range of problems and challenges. Shortcomings in decentralization were affected by the multiplicity of agencies involved, a lack of clear distinction in responsibilities, and difficulties in coordination. The formation of Departments of Natural Resources and Environment has led to low morale in environment staff in some provinces. Interviews with staff reveal several issues: (a) loss of clear identity and sense of mission; (b) loss of influence and authority on environment issues; and (c) distraction from environmental priorities and duties in daily work. The loss of many trained environment staff that remained in the Department of Science and Technology has is some provinces undercut the effectiveness of the environment divisions. A significant increase in environmental staff and an increase in the status of the environmental and natural resource management divisions are needed.

The MONRE Department of Organization and Personnel has estimated that many thousands of staff throughout the country require intensive retraining if environmental management functions are to be effectively fulfilled at the local level. This capacity situation will become more serious as the detailed responsibilities in implementing new environmental legislation and policy approaches begin to filter down through regulations and instructions from the center. There is an imbalance between responsibilities and capacities in which the local level is acquiring more to do but capacity is concentrated at the center.

\section{H. Development Policy and Institutional Arrangement}

Policy, institutional, and legal and instruments for environmental protection and industrial pollution management have been issued by the Politburo, the Government of Vietnam, and the Ministry of Natural Resources and Environment. Strategies and plans for implementation of industrial pollution management have been approved or tabled by the Government, Ministry of Planning and Investment, and the Ministry of Natural Resources and Environment ${ }^{55}$ and some Departments of Natural Resources and Environment. ${ }^{56}$

54. Government Decree No.172/2004/ND-CP dated on 29 September 2004.

55. Notably Decision No. 328/2005/QD-TTg, Approval of National Plan for Environmental Pollution Control until Year 2010.

56. Provincial Industrial Pollution Management Plans of Ha Noi, Hai Phong, Da Nang, Binh Duong, Long An, Bac Ninh and Hai Duong were presented to MONRE Minster at the Final Project Steering Committer of the Vietnam Canada Environment Project, May 4, 2005. 
However, a continuous refinement of roles and responsibilities for all institutions involved in industrial pollution management is needed. The institutional framework and mandate for the decentralization of environmental management to Provincial Peoples Committee, Departments of Natural Resources and Environment, and other agencies and organizations has evolved rapidly over the past decade. Some decentralized agencies have shown remarkable achievements in capacity development in industrial pollution management despite being almost overwhelmed by the industrial growth and expansion in their provinces.
To be effective in implementing its mandate, Ministry of Natural Resources and Environment and other ministries with responsibilities in industrial pollution management need to build and maintain a wide range of working relationships. Within the Ministry of Natural Resources and Environment, roles and responsibilities for industrial pollution management need attention. Table 3.1 illustrates MONRE departmental jurisdictions requiring rationalization for industrial pollution management:

Table 3.1 Pollution management responsibilities requiring clarificaion in MONRE departmental mandates

Pollution management responsibility requiring clarification

National pollution policies, strategies and plans

EIA appraisal

SOE reporting and monitoring

National environmental indicators

Certification and compliance

Water effluent licenses, charges and compliance

Water classification and monitoring

Mining environmental standards, SEA/EIA and compliance

Mining licenses, charges and compliance

Environmental restoration and clean up

Environmental technologies and cleaner production

Pollution information and communications

\section{Existing MONRE Organizations affected}

DOE, VEPA, DWRM

VEPA, DEIAA

DOE, VEPA

VEPA, DOE

DOE, VEPA,

VEPA, DWRM, DM

DWRM, DOE, VEPA

DOM, VEPA, DEIAA

DOM, VEPA

VEPA, DOM, DWR, DOL

VEPA, DOST

VEPA, MONRE Information Center, DOE, DWRM

Source: Authors. 
Of great significance therefore will be the strengthening of the Ministry of Natural Resources and Environment and possibly of the Departments of Natural Resources and Environment now being discussed within the Ministry, and the roles and responsibilities of Provincial, District and Commune Peoples Committees and their jurisdictions and working relationships with each other. The role of the Vietnam Environmental Protection Agency and Department of Water Resources Management (DWRM) will require special attention. The need for a sharply focused national pollution control approach is more pressing than ever. The demands on the Vietnam Environmental Protection Agency and Department of Water Resources Management during the next decade in building the capacities for industrial pollution management within development sectors, at local level, and with the private sector will intensify. The Vietnam Environmental Protection Agency and Department of Water Resources Management will need to take the lead in that work and to collaborate together closely. A great deal of investment in time and resources will be required in outreach, with the Ministry of Natural Resources and Environment facilitating and guiding others in their more rigorous pollution prevention and control responsibilities. Devolving and decentralizing authority and functions does not mean that there will be less work for the Vietnam Environmental Protection Agency and Department of Water Resources Management; on the contrary, there will be a period of transition of 5 to 10 years when the agencies will be busier than ever putting in place the systems and capacities. During that period, it may be best for the Vietnam Environmental Protection Agency to return to its roots and refocus on pollution management. Equally important, will be the clarification of the roles and responsibilities of those ministries with dual responsibilities (ownership and control of industries and industrial parks) at national and decentralized levels - notably the Ministries of Industry; of Construction; of Transport; of Planning and Investment; and their departments in the provinces and districts. Furthermore, the clarification of roles and responsibilities for IPM policy tools need attention and determined implementation by government at national and decentralized levels.

\section{Industry Managers and Owner}

The industrial sector in Vietnam is undergoing major changes as the country modernizes and increasingly participates in the global economy. These changes are largely driven by the shift of focus from self sufficiency to market supply. There has been mounting investment in Vietnamese industry, particularly manufacturing, by Taiwan, Japan, Korea, and Singapore; by overseas Vietnamese; and domestically by all levels of government and private sector entrepreneurs. The line ministries responsible for the state-owned industries that supplied the goods and services necessary for self sufficiency under the Socialist system are now transforming their stateowned enterprises to service and compete in the marketdriven economy. This transformation encompasses changes to all aspects of SOE structure and operations: capitalization, financial accounting, management systems, production technology, supply chains, and labor. It also involves major shifts in the way line ministries function to emphasize regulation and oversight of industry and to provide the right mix of incentives so that enterprises operate in the public interest. In general the state-owned enterprises lag far behind foreign-invested joint ventures in production efficiency. Domestic private sector industries range from facilities with modern and efficient production processes to household industries using traditional technologies and intensive labor.

The need for improvements in environmental management and energy consumption have emerged as major issues, as industrial pollution intensifies in parallel with industrial growth. Further complicating their task is the continuing high level of industry ownership by these same ministries. Therefore, contentious and often contradictory decisions are required of these ministries to adjust their industrial development strategies, maintain employment, and be in accordance with environmental protection objectives.

\section{(1) Ministry of Industry}

The Ministry of Industry leads the development and management of 9 key industrial sectors - machinery, metallurgy, electricity and renewable energy, oil and gas, mining, chemicals, explosive materials, consumer goods,

57. Decree 55/2003/ND-CP, 28 May 2003, Prime Minister. Assigning Functions, Tasks, Responsibility and Organization of MOI. 
and food processing. ${ }^{57}$ It shares management of some of these sectors with other ministries; for example the Ministry of Fisheries (MOFI) is responsible for seafood processing, and Ministry of Agriculture and Rural Development (MARD) shares responsibilities for craft villages, Ministry of Natural Resources and Environment for mining, and the Ministry of Planning and Investment for industrial parks. These fields of overlap create uncertainty, particularly for environmental protection, and need to be resolved. All the MOI-managed manufacturing sectors - machinery, metallurgy, chemicals, explosive materials, consumer goods and food processing - have significant pollution problems.

The Ministry of Industry has 13 departments, 9 public service units (including research institutes such as Industrial Institute for Planning and Strategy). There are Departments of Industry in every province, and 23 colleges and training centers. The Ministry of Industry has ownership positions in over 2,000 industries, including 51 large general companies and enterprises (such as Energy Vietnam, PetroVietnam, VinaCoal) and numerous enterprises concerned with steel, petroleum, chemicals, textiles, paper manufacturing and coal mining. By June 2005, some 300 (15 percent) of the MOI state-owned enterprises had been equitized. Equitization changes the ownership of the registered capital of the state-owned enterprise. On average, the state holds 46.5 percent, the staff holds 38.1 percent; and other shareholders hold 15.4 percent of the registered capital of the equitized enterprise. Four large MOI corporations - VinaCoal, Vinatex, PetroVietnam, and Energy Vietnam - are slated for equitization.

Pollution control and environment protection are not identified as a central function of the Ministry of Industry. These responsibilities are mentioned in some industrial development strategies and plans, as well as allocated by the Government and Ministry of Natural Resources and Environment to the Ministry of Industry and to various $\mathrm{MOI}$ institutions, such as the Energy Institute and the Institute of Policy and Strategic Planning. The Institute of Policy and Strategic Planning has submitted a proposal to amend Government Decree 55/2003 to increase the environmental protection functions of the Ministry of Industry and to more fully embrace the polluter-pays principle adopted in the Government's National Agenda 21 and Environment Protection Strategies. Drafts of the Industry Sustainable Development Framework, the Industrial Environment Protection Strategy, and the Regulation on Environment Protection in Industry are in the final stages of preparation, all with a central focus on the Ministry's environmental and sustainable use responsibilities. During 2005-2006 the Ministry of Industry took a leading role in drafting a Government Decree on the management of hazardous chemicals. Those initiatives potentially reflect a major step forward in its role as an advocate and promoter of sustainable use and cleaner production.

The $\mathrm{MOI}$ Minister assigns administrative functions to 4 vice ministers, one being responsible for industrial pollution and environmental management. ${ }^{58}$ The Department of Science and Technology within the Ministry of Industry is mandated with pollution and environment policy implementation and drafts environmental protection regulations to submit to the MOI Minister for approval. The Department of Science and Technology has 3 staff working on environment issues and in 2006 established an Environment Division. The provincial Departments of Industry have begun to respond to the environmental problems in the industries they manage but generally these staff have only limited training and understanding of industrial pollution management. Some Departments of Industry have assigned environment protection tasks to their Science and Technology Divisions. The Institute of Policy and Strategic Planning supports the Departments of Industry in environmental studies and policy drafting. Some $\mathrm{MOI}$ companies are becoming more responsive to environmental issues and concerns. For example, Energy Vietnam has assigned environmental concerns to its Division of Science and Technology with one full-time environmental specialist. VinaCoal has an environmental fund that has operated for ten years. Yet, investment in environment protection by $\mathrm{MOI}$ companies remains small and insufficient at well under 0.25 percent of company turnover.

58. Decision 1636 / QD-TCCB, 29 June 2004, of MOl's Minister on assigning tasks and responsibility to MOI leaders. 


\section{(2) Ministry of Construction}

The Ministry of Construction (MOC) is responsible for the overall management of the construction materials industry and for infrastructure related to waste management. Though contributing much to the development of the national economy, some production units of building materials and mechanics industry consume natural resources and energy inefficiently and cause significant environmental impact, particularly the MOC industries for cement production, brick making, roofing materials, lime exploitation, mechanical processing, and materials casting, plating, and thermal treatment subsectors. The construction industry sector consists of 2 major production divisions - building materials production and building machinery and mechanics - which over all cover 7 subsectors. ${ }^{59}$

Strategies and Master Plans provide the overall vision and targets for the development of programs and projects in the domain of the Ministry of Construction. In addition, there are Provincial Construction Master Plans, which are approved by the Provincial Peoples Committees, to guide industrialization at provincial and local levels. At the Ministry of Construction, the Department of Science and Technology works on environmental protection policy and technical guidelines. The Department for International Cooperation has assisted the Ministry of Construction to implement a number of projects with donor agencies, some of these related to environmental protection. The Ministry of Construction has centers, institutes, and educational institutions that continue to develop expertise in environmental protection and pollution prevention and control. In the provinces, the Departments of Construction report to a Vice Chair of the Provincial Peoples Committee. In some provinces there are Department of Construction staff with environmental responsibilities. Some Department of Industry staff have received training and participated in seminars and workshops on environmental protection and industrial pollution management through Ministry or Department of Construction initiatives or donor projects. DOC personnel have participated in most of the industrial pollution management training and capacity initiative of the VietnamCanada Environment Project in seven provinces. ${ }^{60}$

\section{(3) Ministry of Planning and Investment}

The Ministry of Planning and Investment has great potential to promote and require industrial pollution management approaches. It has a wide range of functions and powers influencing many aspects of industry planning and management, and could, if it chose, use that authority much more decisively in advocating and integrating the Government's environmental policies in the industry sector. Regarding industrial pollution, the Ministry of Planning and Investment has prime responsibility for developing the strategies, programs, and plans on reorganization, renewal, and development of state enterprises and development of small- and medium-sized enterprises of various economic sectors. And overall, the Ministry acts as the principal body in managing activities of domestic and foreign direct investment, and guides and monitors the course for formulating and realizing investment projects.

The Ministry of Planning and Investment has 20 departments that mirror the structure of line ministries and agencies. The Departments of Industrial Economy, of Industry Park and Export Processing Zones, and of Small and Medium Enterprise Development are directly concerned with industrial development. The Department of Industrial Economy also has surprisingly wide functions given the existence of sector ministries such as Industry and Construction ready to take on these roles. It is also the key department for monitoring implementation of industrial programs and projects and for reporting annually on performance. Industry development issues also relate to other MPI departments such as General Department, Regional and Local Economy Department. Its Department of Science, Education, Natural Resources and Environment is also a potential key player in applying environmental policies and procedures in industrial strategies, plans and projects

59. Building materials production includes cement production industry; bricks and tiles production industry; building ceramics production industry; asbestoscement roofing panel manufacturing industry; building stone exploiting industry. Building machinery and mechanics includes casting industry and building machinery mechanics processing and production industry.

60. Vietnam Canada Environment Project. 1996-2006. Provinces of Hanoi, Hai Phong, Binh Duong, Danang, Hai Duong, Bac Ninh and Long An.

60 Rural Development, Natural Resources and Environment Unit of the East Asia and Pacific Region 
Two MPI institutes are influential in defining plans and policies and have had an important role in various environmental studies. The Development Strategy Institute is concerned with the preparation of strategies and plans for the economic regions. And the Central Institute for Economic Management Studies is closely involved in exploring the use of economic instruments in environmental management. Finally, the Department of Science, Education, Natural Resources and Environment has responsibilities for integrating environment into development plans of the sectors and areas and monitoring performance in implementation.

\section{(4) Ministry of Agriculture and Rural Development and the Ministry of Fisheries}

The Ministry of Agriculture and Rural Development and the Ministry of Fisheries are dealt with together because of the fundamental difference in their mandates compared to the other regulators. These two ministries are primarily concerned with the use of natural resources - land and soils, forests, water, and fish and have a state-level function for management of forestry and fisheries. The other industry regulators analyzed - MOI, MOC, and MPI - are solely concerned with the industries they manage and the infrastructure they provide.

The Government recognizes that economic productivity is dependent on the conservation and sustainable use of natural resources and on environmental amenity. That overarching Government policy position is not consistently applied by the managers of manufacturing sectors. In fact, it is only over the past decade that even the Ministry of Agriculture and Rural Development and the Ministry of Fisheries have begun to significantly reorient to sustainability rather than production maximization. That shift in their policies, strategies, and plans has followed an urgent need to confront a collapse in natural resource stocks. The primary and manufacturing industries managed by the Ministry of Agriculture and Rural Development and the Ministry of Fisheries have an immediate link with the natural resources they use; even small fluctuations in accessibility and quality have direct and immediate repercussions on their economic viability.

That intimate link has led the two ministries to introduce some of the most advanced legislation and regulations in the region on sustainable management of the natural resources for which they have responsibility. On the other hand, these ministries also have to regulate the industry sectors that fall under their responsibilities to minimize environmental impacts, including pollution. In many ways managing the environmental performance of related industries is not different from any other sector; there are factories that are seriously polluting the local environment and using resources wastefully. What becomes clearer though in examining the Ministry of Agriculture and Rural Development and the Ministry of Fisheries is the importance of taking area-wide or natural resource-based approaches to pollution management.

The Ministry of Agriculture and Rural Development and the Ministry of Fisheries should continue with their process of internal role separation. While this has been established at a basic level for forestry, there is no organization with policy or environmental management responsibilities for the other rural development mandates of the Ministry of Agriculture and Rural Development. The environmental management responsibilities of its other non-forestry agencies need to be defined. Similarly, the Ministry of Fisheries should clarify the management responsibilities of the Department of Science and Technology. One Department should have overall responsibilities for fisheries policy, sustainability, and standard setting. The other departments should focus on fisheries operations and all aspects of food safety. Also, the Ministry of Agriculture and Rural Development should establish a department with overall responsibilities for environmental protection policy, sustainability, and operational standardsetting. The other agriculture and rural development departments should focus on operations and service delivery. The current agriculture and rural development departments with environmental and pollution prevention obligations need to strengthen and extend the formal working relationships with the Ministry of Natural Resources and Environment to ensure a consistent national approach. Ministries and provinces should develop their approaches in this area based on the national framework.

The Ministry of Agriculture and Rural Development and the Ministry of Fisheries need to accelerate the equitization of state-owned enterprises and progressively divest all commercial business activities. Wherever possible, these should be taken over by the private sector under policies and standards set by the Government. Institutional functions and responsibilities will be devolved to the lowest possible level once the capacity and conditions exist for these levels to fulfill the institutional mandates. 


\subsection{The Regulatory Framework}

To implement the environmental protection and natural resource management policies, the Government has enacted and promulgated the following laws of importance for pollution management: (a) Amended Law on Environmental Protection (b) Law on Land (2003) and related Order No. 23/2003/L-CTN of December 10, 2003, on the promulgation of the Land Law and decree on the implementation of the Land Law; and (c) Law on Water Resources (1998) and Decree No. 179/1999/ ND-CP of December 30, 1999 on the implementation of the Law on Water Resources. Also, other recently promulgated legal instruments, particularly for environmental protection include targeted initiatives at severe polluters, ${ }^{61}$ on sanctions for administrative violations, ${ }^{62}$ on pollution charges, ${ }^{63}$ on licensing water usage and discharges, ${ }^{64}$ and the establishment of an Environment Fund. ${ }^{65}$

\section{A. The Amended Law on Environmental Protection}

The Amended Law on Environmental Protection was approved by the National Assembly in 2005 and came into effect on July 1, 2006. Roles and responsibilities are clarified in an Implementation Decree of the Prime Minister. ${ }^{66}$ Table 3.2 illustrates the complexity of the coordination task facing the Ministry of Natural Resources and Environment in facilitating implementation of the ALEP and the importance of developing effective working relationships with other line ministries.

Table 3.2. Amended Law on Environmental Protection - National Roles and Responsibilities

\begin{tabular}{|c|c|c|}
\hline $\begin{array}{l}\text { National institution } \\
\text { or organization }\end{array}$ & Selected roles and responsibilities for environmental protection & ALEP coverage \\
\hline \multirow{4}{*}{ Central Government } & $\nabla$ Responsibilities of state management agencies & Article 121.1 \\
\hline & $\begin{array}{l}\text { Responsibilities and competence to decide on handling of polluting production, } \\
\text { business and service establishments }\end{array}$ & Article 49.3.c. \\
\hline & $\nabla$ Establishment of specialized environmental protection agencies and staffs & Article 123.1. \\
\hline & 凶 Environmental tax & Article 112. \\
\hline \multirow{4}{*}{$\begin{array}{l}\text { Ministry of Natural Resources } \\
\text { and Environment }\end{array}$} & $\triangle$ Primary responsibilities & Article 121.2. \\
\hline & $\otimes$ State budget for environmental protection & Article 111.3 \\
\hline & $\begin{array}{l}\text { Q Responsibilities and competence to decide on handling of polluting production, } \\
\text { business an service establishments }\end{array}$ & Article 49.3.d. \\
\hline & Q Responsibilities for environmental protection supervision and inspection & Article 126. \\
\hline \multirow{2}{*}{$\begin{array}{l}\text { Ministry of Planning } \\
\text { and Investment }\end{array}$} & $\nabla$ Primary responsibilities & Article 121.3; \\
\hline & $\otimes$ State budget for environmental protection & Article 111.3 \\
\hline
\end{tabular}

61. Decision No. 64/2003/QD-TTg. April 222003.

62. Decree No. 121/2004/ND-CP, May 12, 2004.

63. Decree No. 67/2003/ND-CP, June 132003.

64. Prime Ministers Decree 149/2004/ND-CP, July 27, 2004.

65. Decision No. 82/2002/QD-TTg, June 262003.

66. Decree No. 175-CP of 18th October 1994 Guiding the Implementation of the Law on Environmental Protection of 1993. 


\begin{tabular}{|c|c|c|}
\hline $\begin{array}{l}\text { National institution } \\
\text { or organization }\end{array}$ & Selected roles and responsibilities for environmental protection & ALEP coverage \\
\hline \multirow{2}{*}{ Ministry of Finance } & 凶 State budget for environmental protection & Article 111.3 \\
\hline & \ Environmental protection charges & Article 113. \\
\hline \multirow{2}{*}{$\begin{array}{l}\text { Ministry of Agriculture and } \\
\text { Rural Development }\end{array}$} & $\otimes$ Primary responsibilities & Article 121.4; \\
\hline & $\otimes$ Environmental protection in agricultural production & Article 39. \\
\hline \multirow{2}{*}{ Ministry of Industry } & $\otimes$ Primary responsibilities & Article 121.5; \\
\hline & घ Environmental protection in mineral activities & Article 44. \\
\hline \multirow{2}{*}{ Ministry of Fisheries } & $\otimes$ Primary responsibilities & Article 121.6; \\
\hline & $\nabla$ Environmental protection in aquaculture & Article 47 \\
\hline \multirow{2}{*}{ Ministry of Construction } & $\otimes$ Primary responsibilities & Article 121.7; \\
\hline & 凶 Hazardous Waste Management & Articles 70-76. \\
\hline \multirow{2}{*}{ Ministry of Transport } & $\otimes$ Primary responsibilities & Article 121.8; \\
\hline & Environmental protection in transport and traffic activities & Article 41. \\
\hline \multirow{2}{*}{ Ministry of Health } & $\otimes$ Primary responsibilities & Article 121.9; \\
\hline & घ Environmental protection in hospitals and other medical establishments & Article 46. \\
\hline \multirow{2}{*}{$\begin{array}{l}\text { Ministry of Defense and } \\
\text { Ministry of Public Security }\end{array}$} & Q Primary responsibilities & Article 121.10 \\
\hline & 凶Specialized environmental protections inspectorates & \\
\hline $\begin{array}{l}\text { Ministry of Science } \\
\text { and Technology }\end{array}$ & $\nabla$ Development of environmental protection science and technology & Article 108. \\
\hline $\begin{array}{l}\text { Ministry of Education } \\
\text { and Training }\end{array}$ & $\otimes$ Environmental education and training of human resources for environmental protection & Article 108. \\
\hline Source: Authors & & \\
\hline
\end{tabular}

The ALEP establishes jurisdictions, roles, and responsibilities for all levels of government, regulatory agencies, and regulated entities and activities. The ALEP also provides coverage for the application of the industrial pollution management policy tools; it also provides the basis for environmental standards, including those for waste discharge, and provides the requirements for strategic environmental assessment reports. Organizations and individuals must comply with environmental protection requirements not only during inventory, exploration and the exploitation and use of natural resources, but also upon completion of the exploitation activities.
Under the ALEP, prohibited acts include discharging wastes untreated to environmental standards; discharging toxic, radioactive and other hazardous substances into land or water sources; and emitting smoke, dust, or gases with toxic substances or odor into the air. Articles 39 to 54 make specific provisions for the environment protection requirements. The ALEP has strong provisions for dealing with production and service establishments causing environmental pollution either through pecuniary penalties or suspension of activities until the necessary mitigating and treatment measures have been completed. In cases where there is damage to the lives or health of humans, or damage to property or the interests of 
organizations and individuals, those who suffer damage are to be compensated in accordance with stipulations in the Law, relocate such establishments to places suitable to environmental load capacity; or ban the operation. In addition, ALEP provides a comprehensive basis for managing water quality in Vietnam. However, as many of its provisions are new and guidelines on their application need to be developed, awareness rising is needed for ALEP to become more effective and better understood in the community.

To date, ALEP is seen as the most notable achievement for improving industrial pollution management; important innovations in the amended law include:

- A broader range of national, regional, sectoral, and local investment plans and projects subject to the SEA EIA process, and stricter licensing and approval framework for investment projects; ${ }^{67}$

- Provision of supplementary regulations to address the responsibilities, processes and management of various types of waste, including hazardous waste;

- Clearer environmental quality and waste standards and delegation of greater legal authority to state agencies to introduce environmental quality regulations;

- Public disclosure of information so that new regulations require public consultations for environmental impact assessment and waste collection and management; and

- Improved definition of responsibilities for relevant agencies related to environmental incidents.

\section{B. Law on Water Resources}

The Law on Water Resources (1998) covers surface water, rain water, groundwater, and sea water. Under the Law, it is strictly prohibited to introduce into water sources, without a permit, any noxious waste, unprocessed discharge water, or water that has been processed but not up to the permissible standards as provided for by the legislation on the protection of the environment.

Permits to discharge wastewater must be based on the receiving capacity of the water source and the assurance of no pollution and the protection of the water resource. Those discharging wastewater under a permit must process it in order to reach the permissible criteria before discharge; and they must pay compensation for any damage. The Law on Water Resources specifically requires that organizations and individuals using chemicals in agricultural production and raising aquatic and marine products must not cause pollution of the water source.

The Law on Water Resources provides that organizations and individuals have rights to exploit and use water resources. Generally a license is required to take and use water, but there are some exceptions - one relates to the exploitation and use of surface water and underground water at the family scale in agricultural, forestry production, aquaculture, small industry and handicraft production, hydropower generation, and other purposes. The Law on Water Resources also requires that the exploitation and use of water resources for fishing and aquatic and marine culture must not deteriorate and exhaust water resources; nor interfere with waterways, damage irrigational works, and block navigation; nor salinize water resources and agricultural land.

The Law is strong on the intent of not allowing the discharge of polluting wastewater. It provides for the setting of water quality standards for receiving waters, but no further details are provided to guide the development of policies and the required secondary legislation. The Law does not provide a statutory basis for allocating water for the environment or for such purposes as preventing saline intrusion. It also does not provide a basis for managing demands for water across water sectors through pricing, education, etc. The Law makes no reference to community participation in water resource management and does not establish any statutory mechanisms for community input into major water resource management decisions, such as licensing or river basin plans. There are also overlaps and inconsistencies between the Law on Water Resources, the Amended Law on Environmental Protection, and the Land Law.

67. Vietnam 2005 Rapid Country Assessment Report: Environmental Compliance and Enforcement Program. December 2005. Planning and Development Collaborative International, Inc. (PADCO). 


\section{The Land Law}

The 2003 Land Law has strong provisions concerning land use zoning and land use planning as a basis for land allocation. One of the principles for this planning requires the reasonable exploitation of natural resources and the protection of the environment. Under the Land Law, the contents of land use zoning and land use plans must include the determination of methods of use, protection and improvement of land, and protection of the environment. Changing land use and transfer of land use structures must be in accordance with the contents of a land use plan. In relation to craft villages, Article 93 has provisions concerning land used as sites for production and business activities, such as land for construction of premises for manufacturing, small industry, domestic industry, trade and services, and other constructions serving production and business activities. The use of land for production and business must comply with approved detailed land use zoning and approved detailed land use plan, approved detailed urban construction plan, approved rural construction plan, and provisions concerning environmental protection.

Article 95 has provisions on land used for production of construction materials and ceramic products. The use of land for such purposes requires that measures are in place to ensure that no damage is caused to production activities and life of the people, and no detrimental effects are caused to the environment; and on completion of the exploitation of raw materials, the land must be returned to the condition stated in the lease.

The Land Law deals with the use of inland water for aquaculture cultivation or breeding or agricultural production. The use of land for these purposes must conform to the approved land use zoning and land use plan; ensure the protection of land; and contribute to the protection of the ecosystem, the environment, and the landscape. Also, the Land law includes a section dealing with agricultural land. It sets limits on the area of agricultural land to be allocated, on agricultural land use, and agricultural land used for public interests. It also provides for the allocation or lease of production forestry land. Coastal land will be leased by the state for the purposes of agricultural, forestry, or salt production. The use of coastal land for these purposes must conform to the approved land use zoning and land use plan, ensure the protection of land, and contribute to the protection of the ecosystem, the environment and the landscape.

\section{The Socio-Economic Development Plan for 2006- 2010}

The Socio-Economic Development Plan and the related strategy for its implementation, ratified by the Ninth Party Congress, acknowledges that rapid development and economic growth must proceed in parallel "with realization of social equality, progress, and environmental protection." The Development Plan has sections on environmental protection, conservation of natural resources, and sustainable development. Some major targets must be reached by 2010 , including those most relevant to industrial pollution management listed below:

- 100 percent of newly-established units must apply clean technology or be equipped with pollutionreducing and waste-treating facilities to meet environmentally-related standards.

- 50 percent of production units should obtain ISO 14001, Certificate or Certificate of Environmental Standards Satisfaction.

- 40 percent of the urban areas, 70 percent of industrial and export processing zones must have standardized wastewater treatment facilities; 90 percent of residential, industrial and service waste should be collected; 60 percent of hazardous waste and 100 percent of hospital waste should be treated.

- Seriously polluted production units should apply various measures (closure, upgrades in technology, or investment in waste treatment systems). ${ }^{68}$ The Plan identifies 4,295 seriously polluting production units and proposes appropriate measures (e.g., renovating and upgrading technology, building wastewater treatment works and closing down some facilities) to minimize pollution, and establishes a step-by-step schedule to

68. Prime Minister's Decision No. 64/2003/QD-TTg dated April 22, 2003 ratifying the Plan to address seriously-polluting production units to protect the environment and community's health in densely populated and polluted areas. 
deal with such units from 2003 to 2012.

- 50 percent of seriously polluted canals, lakes, and ponds in urban areas should be improved.

\section{E. National Strategy for Environmental Protection until 2010 and Orientation toward 2020}

In 2003, the Government issued the comprehensive National Strategy for Environmental Protection (NSEP) to 2010 and Orientation to $2020 .^{69}$ The 10-year Strategy is organized into 36 programs. Priority ranking, target completion date, and implementing and coordinating agencies are assigned to each program. Programs of particular relevance to industrial pollution management from Section 1: Pollution Control and Prevention and Section 4: Environmental Protection of Focal Areas are:

- MT.PK1: Resolving of industries that seriously pollute the environment.

- MT.PK2: National hazardous waste management.

- MT.PK3: Medical waste treatment.

- MT.PK5: Cleaner Production and environmentally friendly technology adoption in Vietnam.

- MT.PK6: Incentives for enterprises in environmental protection and international economic integration.

- MT.PK7:Developmentanimplantationofenvironmentally friendly technology innovation road-map.

- MT.KV3: Construction of central wastewater treatment system meeting environmental standards in all industrial parks.

- Of particular relevance to industrial pollution management from Section II: Programs to Implement Solutions of the Strategy:

- MT.GP1:Strengthening of the governance of environment protection at central, local and sectoral levels.

- MT.GP2: Improvement and enforcement of the environmental legal system.

Implementation of the National Strategy for Environmental Protection by relevant central and local agencies has not been systematic or undertaken with consistent awareness and commitment. The experience emphasizes the need for the Ministry of Natural Resources and Environment to support and facilitate a more systematic implementation. The Ministry of Natural Resources and Environment needs to organize dissemination programs and training courses and develop guiding documents to support and guide ministries, sectors, and localities in preparing their own directives, instructions, and guidelines to drive implementation and appropriate budget allocation. The Prime Minister has approved 36 priority programs and projects to implement the National Strategy. As a ministerial body with principle responsibility in organizing strategy implementation, the Ministry of Natural Resources and Environment needs to issue guiding documents for developing these programs.

\section{F. National Water Resources Strategy}

The National Water Resources Strategy was promulgated in April 2006 to indicate how the Government plans to achieve clear goals and objectives in the water sector in an integrated and effective manner. It provides a framework for water management in Vietnam in the short, medium, and longer term. And it prioritizes Government and nongovernment water management activities. The National Water Resources Strategy presents a consolidated and coordinated statement of the Government's policy on broad topics that affect many ministries and the community. The Strategy is intended to help coordinate and guide the plans and activities of waterrelated ministries, provincial governments, and river basin organizations. It provides the policy framework within which water-related decisions at all levels should be undertaken. The solutions and targets in the draft Strategy involve a mixture of tools to achieve the objectives, including tools that:

- Improve water resource policy and planning at international, national, river basin, provincial levels and locals levels;

- Establish or improve regulatory frameworks to establish clear rights and responsibilities of individuals and organizations exploiting or impacting on the nation's water resources, including licensing and improved assessment procedures;

- Encourage enterprise self-regulation in the areas of 
best practice, water use efficiency, and water service provision; and

- Engage the community in water management, including education and awareness, and participatory mechanisms.

\subsection{Summary}

Policy, institutional and legal instruments for environmental protection and industrial pollution management have been issued by the Politburo, the Government of Vietnam, and the Ministry of Natural Resources and Environment. Strategies and plans for implementation of industrial pollution management have been approved or tabled by the Government, Ministry of Planning and Investment, and by the Ministry and some Departments of Natural Resources and Environment. However, a continuous refinement of roles and responsibilities for all institutions involved in industrial pollution management is needed. The institutional framework and mandate for the decentralization of environmental management to Provincial Peoples Committee, Departments of Natural Resources and Environment, and other agencies and organizations has evolved rapidly over the past decade. Some decentralized agencies have shown remarkable achievements in capacity development in industrial pollution management despite being almost overwhelmed by the industrial growth and expansion in their provinces.

To be effective in implementing its mandate, Ministry of Natural Resources and Environment and other ministries with responsibilities in industrial pollution management need to build and maintain a wide range of working relationships. Within the Ministry of Natural Resources and Environment, roles and responsibilities for industrial pollution management need attention. Therefore, of great significance will be the strengthening of the Ministry of Natural Resources and Environment and possibly of Departments of Natural Resources and Environment (now being discussed within the Ministry), and the roles and responsibilities of Provincial, District, and Commune Peoples Committees and their jurisdictions and working relationships with each other.

Now more than ever, the role of the Vietnam Environmental
Protection Agency and Department of Water Resources Management will require special attention because of the need for a sharply focused national pollution control approach. Much needs to be done to give detailed expression to the good policy frameworks now in place with the Ministry of Natural Resources and Environment facilitating and guiding them in taking on their more rigorous pollution prevention and control responsibilities. Devolving and decentralizing authority and functions does not mean that there will be less work for the Vietnam Environmental Protection Agency and Department of Water Resources Management.

Equally important will be the clarification of the roles and responsibilities of those ministries with dual responsibilities (ownership and control of industries and industrial parks) at national and decentralized levels, notably the Ministries of Industry, of Construction, of Transport; and of Planning and Investment and their respective departments in the provinces and districts. Furthermore, the clarification of roles and responsibilities for IPM policy tools need attention and determined implementation by government at national and decentralized levels. The legal instruments and capacity development of the Provincial Peoples Committee, Departments of Natural Resources and Environment, Districtand Commune-level agencies responsible for industrial pollution management need to be accelerated to stay abreast with industrial growth. The relative responsibilities for pollution regulation within industrial parks need to be clarified so that systematic application of the Amended Law on Environmental Protection is facilitated. All this will require high-level commitment and major investment by the Government.

To implement the environmental protection and natural resource management policies, the Government has enacted and promulgated the following laws of importance for pollution management: (a) Amended Law on Environmental Protection (b) Law on Land (2003) and related Order No. 23/2003/L-CTN of December 10, 2003, on the promulgation of the Land Law and decree on the implementation of the Land Law; and (c) Law on Water Resources (1998) and Decree No. 179/1999/ ND-CP of December 30, 1999 on the implementation of the Law on Water Resources. In addition, several Government strategies are setting the basis to mainstream environmental concerns into GoV economic development policies; of 
particular importance is the comprehensive National Strategy for Environmental Protection (NSEP) to 2010 and Orientation to 2020 - both issued in $2003 .{ }^{70}$ The 10 -year Strategy is organized into 36 programs. Priority ranking, target completion date, and implementing and coordinating agencies are assigned to each program. Also, other recently promulgated legal instruments, particularly for environmental protection, include targeted initiatives at severe polluters, on sanctions for administrative violations on pollution charges, on licensing water usage and discharges, ${ }^{71}$ and the establishment of an Environment Fund.

70. Decision No. 256/2003/QD-TTg dated December 2, 2003 ratifying National Strategy on Environmental Protection from 2003 to 2010 with an orientation to 2020.

71. Prime Ministers Decree 149/2004/ND-CP, July 27, 2004.

68 Rural Development, Natural Resources and Environment Unit of the East Asia and Pacific Region 


\section{SECTION 4. ENVIRONMENTAL PROTECTION EXPENDITURES}

In 2004, the Government of Vietnam decided to increase public environmental protection expenditures to 1 percent of the overall budget. ${ }^{72}$ Environmental authorities in Vietnam have had difficulty in assessing funding needs from year to year in part due to uncertainty on what 1 percent of the overall budget means in practice. When first introduced, it was not clear if 1 percent represented an increase or a reduction in levels of environmental expenditure although the Government's intent was to increase its commitment. The growing pressure on the Government and private sector to raise public expenditure on pollution control stems from the fact that economic costs of pollution are increasing in volume and toxicity.

However, challenges remain in defining and classifying the various components of environmental protection expenditures, including those for pollution abatement and control, and then in estimating expenditure for each component. Article 30 of the 1993 Law on Environmental Protection stipulates that:

Organizations and individuals engaged in production,

business and other activities that cause environmental

degradation, environmental pollution and environmental incidents must implement remedial measures and shall be liable for damages according to regulations by law.

The 1993 Law also defines the responsibilities of various state organizations at all levels for environmental protection management, monitoring, and pollution control. The Amended Law on Environmental Protection (2005) has similar provisions. Yet, in spite of this legal obligation since 1993, pollution abatement and control expenditures and environmental protection expenditures generally were not presented as a separate line item in the state budget until 2006 following the adoption of Resolution 41 of the Political Bureau. As a result, information about environmental protection expenditures has been limited and scattered among different agencies and organizations. The General Statistics Office has not regularly surveyed environmental issues and environmental protection responses by different sectors in the country in spite of its overall mandate to publish data about economic and social activities.
Following Resolution 41, a lengthy debate ensued within Government as to the nature of the activities that should be included as environmental protection activities. In particular, it was argued that the Government was already devoting well beyond 1 percent of its budget expenditures for this purpose if activities such as reforestation and the provision of clean water and sanitation were included. The issue was settled by Decision No. 70, October 192005 from the Ministry of Finance (MOF) on amendments of the system of state budget lines. Article 1 of Decision No. 70 provides a range of activities which should be considered as environmental protection activities for purpose of budget allocation. They include activities related to:

- Investigation, surveys, monitoring, application of technical advancements, management models on environment development and protection;

- Solid waste management (including waste collection, treatment, burying, and burning);

- Wastewater management (including wastewater collection and treatment);

n Air pollution abatement;

- Noise pollution;

- Toxic pollution;

- Natural and biodiversity conservation and protection;

- National programs on clean water and sanitation in rural areas; and

- Other environmental protection activities.

The pollution abatement and control estimates in this report cover two main institutional sectors, the Government of Vietnam and the manufacturing sector. Public pollution abatement and control expenditures are disaggregated by:

- Sources of funding - International development assistance and domestic state budget;

- Regional dimensions - Central and local levels;

- Types - Capital investment and recurrent expenditures;

- Functions - (i) expenditures for policymaking, regulations, monitoring, standards, enforcement; (ii) expenditures for research and development and education, capacity building, training; and (iii) expenditures for infrastructure to mitigate pollution effects. 
For pollution abatement and control expenditures undertaken by the manufacturing sector, the available information only allows for the definition of capital investment and recurrent expenditures.

In a recent report prepared by the World Bank and the Chinese government, it was estimated that environmental pollution cost China about US\$88 billion in economic losses in 2003, accounting for 5.4 percent of GDP. ${ }^{73}$ The environmental costs of air and water pollution accounted for 71 percent and 29 percent, respectively, of the total combined costs. These figures cover (a) public health, agricultural, and materials losses caused by air pollution; and (b) public health, industrial, and agricultural production losses and water shortage caused by water pollution. It does not account for groundwater or soil contamination. In 2004, Vietnam's GDP reached approximately US\$45 billion (GSO, 2006). This review has not attempted to undertake a similar costing exercise as in China. However, assuming that a figure of the same order of magnitude prevails in Vietnam (i.e., 5.4\% of GDP), then the environmental cost of pollution in Vietnam would have reached about US\$2.5 billion.

\subsection{Public Pollution Abatement And Control Expenditures - Capital Investment}

According to the information available in the MPI Public Investment Programs and UNDP Compendium, over the period 1996-2005 there were 145 pollution abatement and control-related projects. Annual expenditures increased significantly over the period 2000-2005 to reach approximately US\$600 million in 2005 (Figure 4.1). These expenditures reached a cumulative level of US\$1.5 billion for the period 1996-2000, and approximately US $\$ 2.3$ billion for the period 2001-2005 indicative of a new level of attention and priority given to pollution control and abatement.

Figure 4.1 also indicates that overseas development assistance has always been the main source of funding for pollution abatement and control expenditures, amounting to approximately US\$3 billion over the period 1996-2005. The
Japanese Bank for International Cooperation, Asian Development Bank, and World Bank contributed approximately US\$603.7 million, US\$411.6 million, and US\$290 million, respectively. Most overseas development assistance went to infrastructure investment. While this assistance remains the largest source of funding for pollution abatement and control, its share has reduced significantly from 83.5 percent for the period 1996-2000 to 73.8 percent for the period 2001-2005. The proportion of domestic state budget funding increased from 16.5 percent to 26.2 percent over the same periods, again indicative of a higher level of priority given to pollution control and abatement.

\section{Figure 4.1. Pollution abatement and control capital expenditures for 1996-2005}

Source: Data of projects for pollution abatement and control funded through overseas development assistance came from UNDP database on environmental projects compendium for

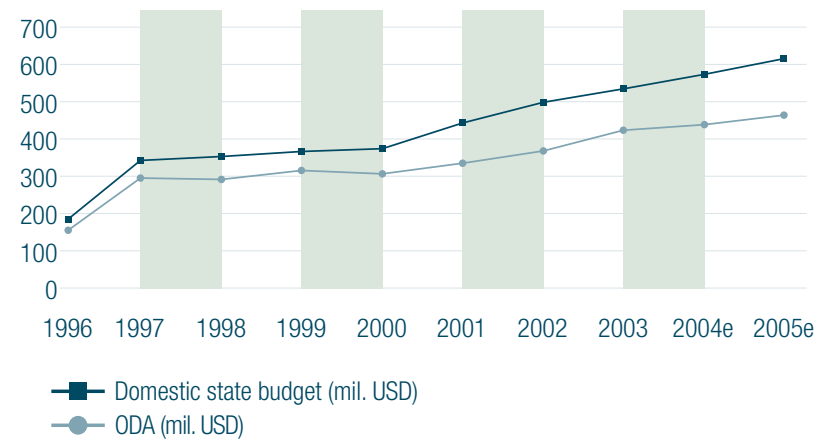

1996-2003. Data on projects funded through the domestic budget came from the MPI Public Investment Programs for 1996-2000 and 2001-2005.

From 1996-2005, most pollution abatement and control expenditures (71 percent) went to infrastructure development projects (Figure 4.2). Yet, this share decreases significantly from 80 percent over the period 1996-2000 to approximately 65 percent over the period 2001-2005. The share of pollution abatementand control expenditures devoted to administration, policy, monitoring, and for research and development and

73. World Bank (2008), Cost of Pollution in China - Physical and Economic Damages. Draft version of March 2008. 
capacity building on the other hand increased from approximately 20 percent to 35 percent over the same period. In absolute terms, capital expenditures for pollution abatement and control devoted to administration, policy, regulation, and monitoring increased from US\$142 million for the five years to 2000 to US\$324 million for the five years to 2005. Similarly, capital investment for pollution abatement and control projects in the area of training, research and development, and capacity strengthening increased from US\$172 million to US\$470 million. Finally, wastewater management attracted the bulk of pollution abatement and control capital expenditures over air pollution control and abatement, and solid waste management (Figure 4.3).

\section{Figure 4.2. Share of pollution abatement and control capital expenditures by activity (1996-2005)}

Source: Data of projects for pollution abatement and control funded through overseas development assistance came from UNDP database on environmental projects compendium for

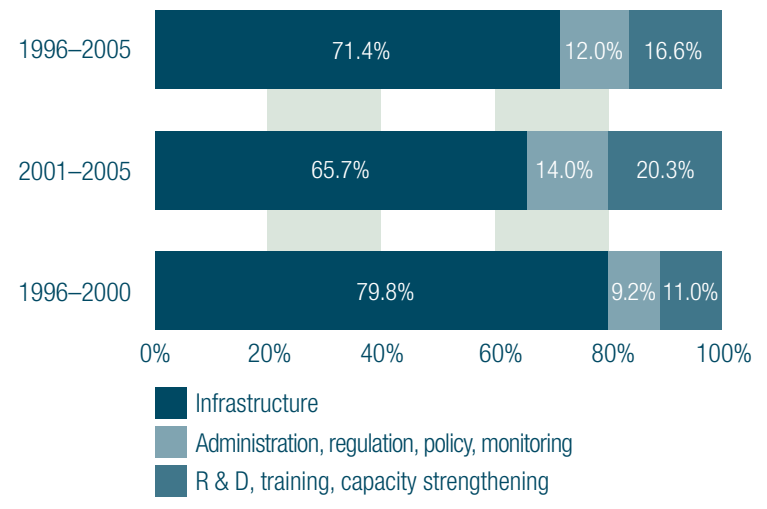

1996-2003. Data on projects funded through the domestic budget came from the MPI Public Investment Programs for 1996-2000 and 2001-2005.

\section{Figure 4.3. Share of pollution abatement and control capital expenditures by sectors}
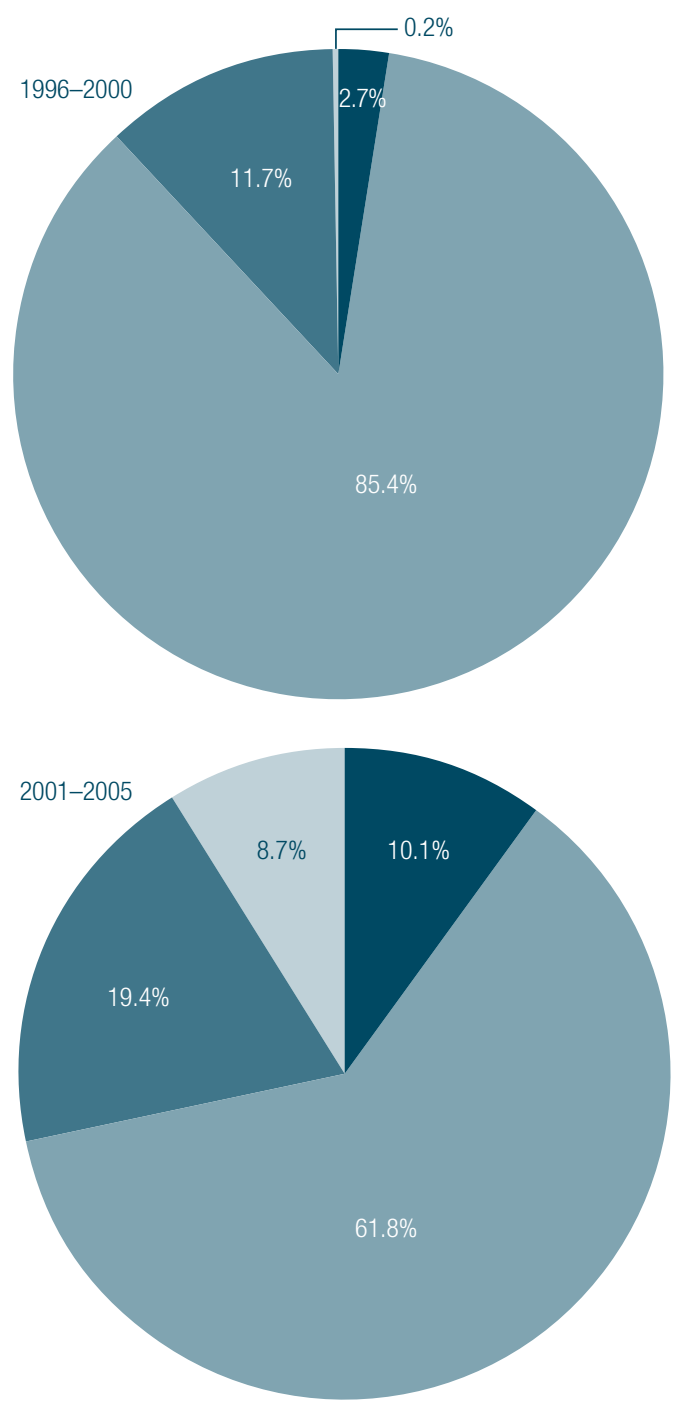

Air pollution

WW management

Solid waste management

Other

Source: Data of projects for pollution abatement and control funded through overseas development assistance came from UNDP database on environmental projects compendium for 1996-2003. Data on projects funded through the domestic budget came from the MPI Public Investment Programs for 1996-2000 and 2001-2005. 


\subsection{Recurrent Expenditures - Budget Allocation}

In 2001, as it was then reported by the National Environment Agency, VND 102,970 million (approximately US\$6.56 million) was spent on environmental protection activities in general. Approximately 60 percent (VND 91,580 million) was allocated to central-level ministries and agencies. The remainder (40 percent) was allocated to provincial and local authorities. In 2001, the Ministry of Science, Technology and Environment was responsible for assessing the budgetary needs of various organizations and distributing the funding. In 2001, the "national program on clean water and sanitation in rural areas" had its own budget line, separate from other environmental protection activities, amounting to VND 159,950 million (US\$10.2 million).

Following the Political Bureau Resolution No 4, the funding situation has changed significantly. First, the Ministry of Finance now plays a more important role in assessing the budget needs of the various organizations with environmental functions and responsibilities, and in disbursing the agreed budgets. With respect to budget assessment and allocation, the role of the Ministry of Environment and Natural Resources has been greatly reduced. Second, VND 2,990,000 million (US\$188.1 million) was allocated to environmental protection activities from the state budget for 2006 . This suggests a 28fold increase in the 2001 budget for environmental protection activities. However, as shown in Table 4.1, following Decision No. 70 , the budget allocated to the "national program on clean water and sanitation in rural areas" is now explicitly included in the budget line dedicated to environmental protection activities. This program had its own budget line in 2001. Once this change is taken into account the total budget for environmental protection activities in 2006 is 11 times higher than in 2001. Third, there has been a significant change in the share of budget allocated to central and. local levels of government. The share of budget allocated to local-level government increased from 60 percent in 2001 to approximately 90 percent, while the share of budget allocated to the central government decreased from 40 percent to 10 percent. Hence, since the adoption of Decision No. 70, provinces have been allocated significantly larger sums of money (recurrent expenditures) to undertake environmental protection activities, which is expected to translate in improved environmental quality on the ground.

Table 4.1. Procedure of Budget Allocation Before and After Decision No. 70

\section{Before Decision No. 70}

Step 1: MOF sends a guideline to ministries and local governments for preparing their state budget estimates for the next fiscal year.

Step 2: MONRE requests Ministries and local governments prepare their budget estimates of state funding for environmental protection activities in next fiscal year.

\section{After Decision No. 70}

Step 1: MOF sends a guideline to ministries and local governments for preparing their state budget estimates for the coming fiscal year.

Step 2: Ministries and local governments should base on the guideline of MOF to prepare the budget plan. In the budget plan, a budget line called "expenditure of public service for environment" is separated.

Step 3: Ministries, state agencies and local governments (i.e. environmental related departments) prepare budget plans for environmental protection activities and send to MONRE.
Step 3: Based on the expenditure for environment in previous year and the need of coming year, the related agencies formulate their estimation of budget for so called "public service" for environment in the fiscal year. 
Before Decision No. 70

Step 4: MONRE then collect all the needs, put them together in the state budget estimate for environmental protection activities in the coming fiscal year and send to MOF.

Step 5: MOF then will make the final decision of allocation of budget for environmental protection activities in the coming fiscal year.

Step 6: Based on the allocated state budget for environmental protection activities, MONRE further distributes funding to related ministries, state organizations in order to undertake environmental protection activities in the fiscal year (based on their budget plan proposed earlier).

\section{After Decision No. 70}

Step 4: At central levels, the ministries and state agencies will then "defend" their budget estimates with MOF.

Step 5: MOF then will make the final decision of allocation of budget to be devoted to ministries.

Step 6: At local level, MOF allocates budget for environmental protection activities based on the following criteria:

\ Population density (convertible);

$\triangle$ Industrial output/ kilometers;

$\otimes$ Number of natural parks and reserve areas.
Budget allocation to provinces for environmental protection activities in 2006 was VND 2,690 billion (US\$169.2 million). Though the amount budgeted for pollution control and abatement cannot be identified from the total allocation, available data illustrate a focus of state budget allocation to Hanoi, Ho Chi Minh City, Hai Phong, Ba Ria-Vung Tau, Binh Duong, Dong Nai, and Da Nang, which are some of the most important areas for industrial pollution in the country. The budget for those provinces accounted for 54.6 percent of the total state budget allocation for environmental protection activities in 2006. However, when normalized for the number of firms or the number of inhabitants in each province, or the size of each province, state budgets allocated to provincial levels of government appear to vary significantly across provinces (Figure 4.4). Ho Chi Minh City and Hanoi receive a large state budget contribution relative to their respective area; yet, when assessed against the number of industrial firms, these cities' budgets for environmental protection activities do not appear among the largest. In fact, provinces with a small number of firms appear to receive comparatively large state budget contributions. This suggests that the number of industrial firms in a province and perhaps even the level of pollution is not a key determinant of state budget allocation.

\section{Figure 4.4. Comparison of state recurrent budget allocation for environmental protection activities in 2001 and 2006}

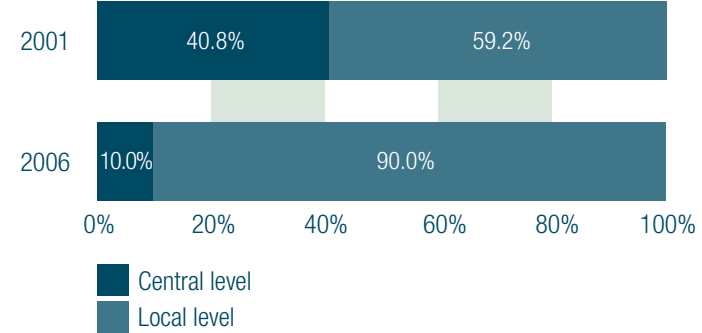

Source: Data from Ministry of Finance and Vietnam Environmental Protection Agency 


\section{Recurrent Expenditures}

Staffing. In 2001, there were approximately 2,250 government employees working in environment-related administrative units. ${ }^{74}$ In addition, there were approximately 430 staff working on environmental management issues in provincial Departments of Science, Technology and Environment. Each individual staff costs an estimated VND 20 million per year. Accordingly, the total budget expenditures for maintaining the environmental management institutions was approximately VND 53,560 million (US\$3.4 million) in 2001. This represents approximately 50 percent of the budget allocated to environmental protection activities in 2001 (excluding the "national program on clean water and sanitation in rural areas"). Similar data were not available for 2006. The increase in overall budget would indicate a much larger workforce devoted to environmental management in general, and pollution control and abatement in particular; and staffing figures available from Ministry of Natural Resources and Environment bear that out.

URENCO. Operating as a state-owned enterprise at the local level, URENCO is a key agent involved in environmental management. While URENCO gains revenue from waste collection fees from clients (domestic households, enterprises, and organizations), most of its funding comes from the state budget. URENCO's budget expenditures increased only slightly from US\$25.1 million in 1998 to US\$25.9 million in 2003. In real terms (net of inflation), it seems that URENCO's budget has in fact declined.

\section{Pollution abatement and control expenditures by industry}

Information on pollution abatement and control expenditures by the manufacturing sector is scarce with no systematic effort to require or manage it. Uniquely, the 2002 GSO Business Survey included a section on pollution control expenditures. Of the 11,265 enterprises surveyed, 40.5 percent provided some (albeit incomplete) answers to this section of the survey. The nature of the information requested was not precisely defined leading to considerable uncertainties as to the reliability of the data provided. Even so, as reported in this survey, VND 233,344 million (US\$14.82 million) was spent in 2002 on pollution abatement and control activities by the responding enterprises (Figure 4.5). This is equivalent to approximately US\$3,000 per enterprise. In 2002, the leading industrial sectors for pollution abatement and control expenditures were (a) food products and beverages; (b) textiles; (c) chemical and chemical products; (d) non-metallic mineral products; and (e) dressing and dyeing of fur. These five industrial sectors accounted for approximately 68 percent of all reported expenditures in the survey. This report identifies the first three of these sectors as among the largest sources of industrial pollution in Vietnam.

\section{Figure 4.5. Pollution abatement and control expenditures by industrial sectors (VND million)}

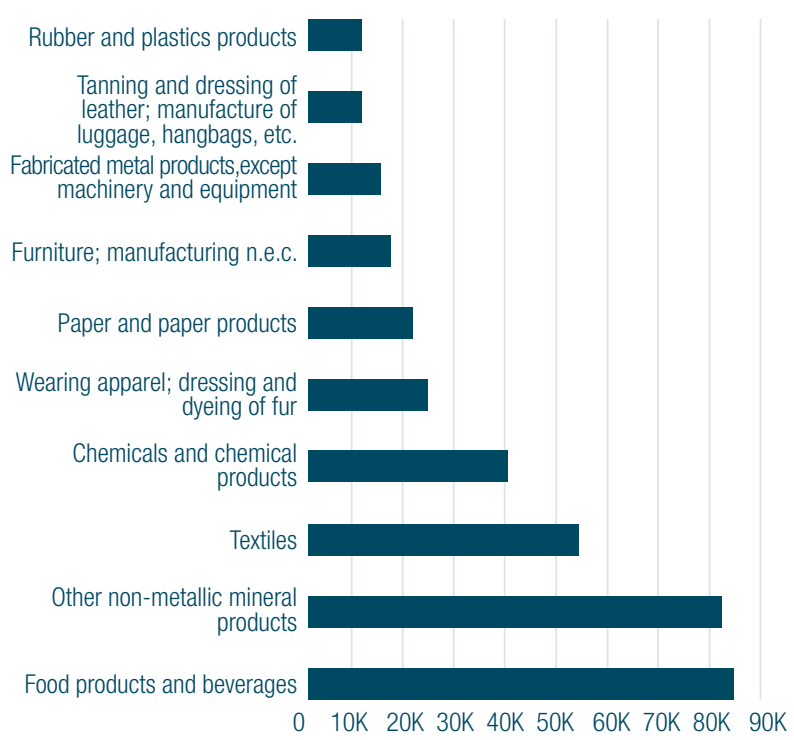

Source: Calculated from GSO survey on enterprises in 2002

74. These administrative units were in the Ministry of Agriculture and Rural Development, Ministry of Industry, Ministry of Construction, Ministry of Transport, Ministry of Fisheries, and Ministry of Science, Technology and Environment. 


\section{Expenditures vs. Pollution Control Objectives}

Public environmental protection expenditures and pollution abatement and control expenditures have increased as a result of Resolution No. 41. Furthermore, Article 1 of Decision No. 70 issued by the Ministry of Finance clearly provides a range of activities considered as environmental protection activities for purpose of budget allocation, and against which 1 percent of budget expenditures is to be calculated. This development represents a significant improvement over an earlier situation where: (a) no clear definition of environmental protection activities existed; (b) no specific budget line for environmental protection existed in the state budget; and (c) no targeted amount of budget expenditures were specifically allocated to support environmental protection activities.

However, the justification for allocation priorities among pollution abatement and control activities is not in place. Are the funds going to the right activities and in the right proportions? There is no mechanism for reconciling budget allocation with specific objectives set forth in the National Strategy for Environmental Protection and the 2006-2010 Socio-Economic Development Plan. These objectives and targets are clearly stated. However, there is no system for reconciling budget allocation against the implementation of these objectives and targets. Such a process would (a) assess the financial needs necessary to achieve each of the above objectives and targets; (b) delineate the various sources of funding, in particular public vs. private, that may be channeled to achieve these objectives and targets; (c) earmark specific state budget toward achieving these objectives and targets; and (d) monitor the performance and effectiveness of state budget allocation toward the achievement of these objectives and targets. In the absence of such a formal process, the main vehicle for achieving government pollution abatement and control priorities becomes relatively arbitrary and steered solely by administrative discretion.

\subsection{Wastewater Fees and the Vietnam Environmental Protection Fund}

With the adoption of two environmental decrees in Vietnam, effective January 1, 2004, both domestic and industrial sectors were required to pay a fee for discharging wastewater to the environment. ${ }^{75}$ Insofar as the industrial sector is concerned, this fee applies directly to the discharge load of seven specified pollutants. Section V of Circular 125 specifies that 20 percent of the collected fees from the industrial sector can be retained by local Department of Natural Resources and Environments to cover the costs of fee collection, wastewater assessment, and sample analysis. The remaining portion of the revenues collected is to be allocated equally between the central state budget and local state budget.

With respect to the proportion of the collected revenues retained in local budgets, the intent of Decree No. 67 is for those revenues to be used specifically for water pollutionrelated issues (e.g., sewerage dredging, repair of water drainage systems) while Circular 125 allows for a much broader use of the revenues targeted at pollution prevention. Discussion with officials in the Ministry of Finance has confirmed that Circular 125 will guide the allocation of revenues from wastewater fees at the local level.

Both documents require that 50 percent of the collected revenues be a recurrent source of revenue (adding to the working capital) of the Vietnam's Environment Protection Fund (VNEPF). ${ }^{76}$ The task of VNEPF is "To provide financial support for programs and projects and activities preventing, combating and overcoming environmental pollution, deterioration and incidents of national, inter-sectoral or interregional nature, or settling environmental matters of local nature but with large impact" (Article 4).

Projects and activities relating to pollution management (albeit not necessarily of industrial sources) are a key focus of the VNEPF. This has been confirmed in the course of discussions

75. Decree No. 67/2003/ND-CP on Environmental Protection Charges for Wastewater (June 13, 2003), and the accompanying Inter-Ministerial Joint Circular No. 125/2003/TTLT-BTC-BTNMT providing guidelines for the implementation of Decree 67.

76. The VNEPF was created by Decision No. 82/2002/QD-TTg of June 26, 2002 on the Setting up, Organization and Operation of Vietnam Environment Protection Fund. 
with VNEPF representatives. However, there does not yet appear to be a clear list of criteria defining project eligibility and potential recipients of VNEPF support. Of the 1 percent of the state budget allocated to environmental protection expenditures (per Resolution No. 41), 10 percent must be allocated to the VNEFP. Hence, a proportion but not all of the VNEPF working capital is a component of the Government's commitment to allocate 1 percent of budget expenditures to environmental protection.

While wastewater fees have been implemented since January 1, 2004, little of the revenues collected by Department of Natural Resources and Environment have been transferred to the central state budget (as required in Decree 67 and Circular 125). This results in a tension between Decree 67 and MOF Decree 57, the latter specifying that local authorities are allowed to keep in their budget and for their use the revenues collected at the local level, including revenues collected through implementation of Decree 67 . The Ministry of Finance is currently attempting to address this inconsistency as part of an overall effort to revise Decree 67.

\subsection{Summary}

The discussion in this section illustrates several issues regarding data availability pertaining to environmental protection activities and pollution abatement and control expenditures in Vietnam and the existing process of budget allocation. In general, the existing data remains at a high level of aggregation and does not allow a distinction to be drawn between pollution abatement and control and other forms of expenditures for environmental protection activities. When data on these expenditures are available, they remain fragmented and incomplete. This is because until 2006, expenditures for environmental protection activities were not reported separately in state budget estimates and statements by the Ministry of Finance. State organizations and agencies, which received funding from the state budget, were never required to separate out environmental protection expenditures in their annual financial report or budget plan. Environmental protection activities and/or pollution abatement and control expenditures are merged with other expenditures in their financial report. Also, although the 2002 enterprise survey undertaken by the General Statistics Office was used here to estimate industry's pollution abatement and control expenditures, the information remains relatively unreliable; enterprises, including state-owned enterprises, do not keep track nor regularly report pollution abatement and control expenditures in their financial accounting system. No state organization is taking responsibility for collecting information on environmental protection activities and pollution abatement and control expenditures and of linking this information to environmental policies and priorities.

The recent commitment to devote 1 percent of budget expenditures to environmental protection activities followed with the adoption of Decision No. 70 offers a new opportunity to set in place a comprehensive tracking system that will be able to tackle those deficiencies. 


\section{SECTION 5. FUTURE DIRECTIONS}

Vietnam is one of the fastest-growing economies in the world - averaging 8 percent increase in GDP annually during 2004-2005 - and is changing rapidly across many fronts. Inevitably, the scale of development envisaged in Government strategies will totally transform the nation's environment. The systems of governance are under continuous change through the Public Administrative Reform process and as new international and domestic challenges arise. Entry to the World Trade Organization and accession to other international agreements are adding to the scale and momentum of change. Each new law adopted by the National Assembly sends powerful waves of reform through all levels of government and other sectors as broad policies and commitments are expressed in detailed implementation arrangements. Complex statutes, such as the Amended Environmental Protection Law, the Land Law, and the Water Resources Management Law, have far-reaching repercussions throughout society. The relationships among government, business, and communities are adjusting in fundamental ways as a result.

Yet, in spite of Government efforts to respond to these changes, environmental capacity and investment is falling well behind levels required to bring the transformation under control. This final section of this report proposes ways in which the Government of Vietnam can raise the bar to address the growing challenges deriving from increasing industrial pollution loads, concentrations, and toxicity. (In Addition, Annex A presents a series of specific actions that could help address the four future directions discussed below).

\subsection{Prioritize Pollution Management Interventions for the Industrial Sector}

This review has estimated the potential pollution releases for all manufacturing sectors and at commune and plant specific levels within ten provinces; it also provided insights on the general types and quantities of pollution releases. Based on these findings, five priority areas have been identified at national and local level: (a) most polluting industries; (b) hazardous pollutants; (c) contaminated sites; (d) industrial zones, and (e) handicraft villages.
To address all five priorities there is a need for a systematic national approach to identify the most important pollutants, enterprises, and areas for priority attention. Issues related to the most polluting industries and hazardous pollutants are addressed in general within the Amended Law on Environment Protection (2005), the National Strategy for Environmental Protection to 2010; Resolution 41/2004 of the Political Bureau; and, specifically for most polluting industries, Decree 64/2003. The other three priorities - contaminated sites, industrial zones, handicraft villages - have not been subject to systematic policy analysis and strategic actions by Government in terms of industrial pollution management. With limited resources and capacities it is not possible to start everywhere at once. In the case of the most polluting industries, there is already a good policy framework and program in place. It requires further elaboration and continuous fine-tuning as more and more serious polluters are effectively managed.

The Government has worked on chemical management for many decades; a complex system has evolved with many gaps and a need for an overarching framework and more precise institutional arrangements. Hazardous chemicals in pollution and wastes require high-priority attention. In this case, too, the tools developed in this report help to more precisely define who is releasing what, how much, and at what stage in the manufacturing process. This is the required first level of information in determining where to focus scarce resources in the control of hazardous pollutants. Contaminated sites are a serious problem for the present and future in Vietnam and require urgent identification, clean up, and rehabilitation. To do so throughout the country will be expensive but more expensive if left without treatment and faced with mounting health and productivity problems.

An initial national register of contaminated sites could build on the good work done in preparing and updating the lists under Decision 64. The pollution situation in industrial parks and handicraft villages might require concentrated and systematic study as a firm basis for introducing IPM responses. An initial straightforward assessment could be undertaken using the IPPS methods if more detailed information could be gathered in the GSO annual industry survey. Technical support to General Statistics Office would be required in the design of additional sections in the survey and in the methods for its implementation. 
Innovative financing options might be required for pollution control in the most seriously polluting industries. Many enterprises are unable to solve or invest in waste treatment systems. They are marginal economically and do not have the resources to invest in what they consider to be nonproductive activities to control pollution. The question arises, how far can and should government go in funding the pollution management systems required? In this transition to industrial pollution management, special subsidy programs are warranted. But over time other funding sources are needed. There is a lack of guidelines and incentives for enterprises to mobilize financial resources for investment in pollution treatment. Part of the problem is a lack of initiative in finding support from credit funds and banks. Generally, there is an absence of financial mechanisms for investments in environment, which limits enterprises' options when they require financial support. National and local environment funds are evolving to fill this gap.

\subsection{Clarify Institutional Roles and Responsibilities for a More Effective Pollution Management}

The Government has been progressively reforming the basis of its public administration to be open and transparent, participatory and equitable, efficient and effective. The Ninth National Party Congress (April 2001) set out a series of Public Administration Reform policies and measures. ${ }^{77}$ Prime Ministerial Decision No. 136/2001/QD-TTg approved the Public Administration Reform Master Programme for the 2001-2010, which provides the basis for on-going reform to public administration.

Responsibilities for pollution management span many fields. No single agency can manage all the processes that influence environmental quality making it essential for an across the board, collaborative approach under a lead agency. By end 2005, the Ministry of Natural Resources and Environment, other ministries, and an international task force finalized the Five-Year Plan (2006-2010) for Natural Resources and Environment Sector. They used a log-frame analytical approach. The Department of Planning and Finance within the Ministry of Natural Resources and Environment has been cooperating with related ministries and departments to formulate a monitoring and evaluation system for implementation of the plan. This system should provide useful and practical information to allow assessments of how well environmental protection initiatives are achieving their objectives.

To ensure that significant progress is made in the short-tomedium term, the Ministry of Natural Resources and Environment and other ministries should promote the establishment and/or strengthening of environmental units in sectoral agencies. The Government has long called for the establishment of environmental units within all sectors. Further progress in industrial pollution management will be seriously constrained until that directive is met and adequate staffing and budgets are provided. Line ministries and their provincial counterparts must establish environmental management units and clearly define their functions, authority, and relationships with the Ministry and Departments of Natural Resources and Environment.

Incentives should be provided for implementation of existing environmental strategies and plans by sectors. The Government should set in place requirements for line ministries and provinces for effective reporting on progress in implementing the main environmental policies, strategies, and plans. While directions are given and broad responsibilities defined, the process of monitoring and reporting on progress is weak. It is facilitated by the Ministry of Natural Resources and Environment as part of the State of Environment Reporting; but there are no incentives for agencies that have performed well; nor disincentives for poor performers. The Ministry of Planning and Investment and Ministry of Natural Resources and Environment need to explore a similar system as part of the socio-economic planning cycle, supported with appropriate indicators of progress. This could be facilitated

77. Policies and measures include applying the principles of multi-sectoral management; delegation and decentralization; separating state management function from production and business activities, and public administration agencies from public service delivery agencies; further reforming state-owned enterprises; and a range of administrative procedures and adjustments to structures and functions. 
by strengthening MONRE capacity as catalyst and facilitator in promoting sector action to implement environmental policies. Each Ministry and sectoral agency requires strong support and guidance in taking a more systematic approach to implementing key environmental policies, such as Resolution NO 41, and related strategies and plans.

The Ministry of Natural Resources and Environment needs to organize dissemination programs and training courses and develop guidance to support ministries, sectors, and localities in preparing their own directives, instructions, and guidelines. The Primer Minister has approved 36 priority programs and projects to implement the National Environmental Protection Strategy. As a ministerial body with principle responsibility in organizing strategy implementation, the Ministry of Natural Resources and Environment needs to issue guiding documents for developing these programs. But, the Government will need to increase substantially the proportion of national budget going to the environment sector, through both the Ministry of Natural Resources and Environment and line ministries.

Tools and mechanisms to systematically integrate environmental concerns into sector operations should also be adopted and developed: As MOI, MOC, MOT and MPI continue to expand their framework of regulations, procedures, and actions in environmental protection and industrial pollution management, certain mechanisms and instruments need to be progressively built into day-to-day operations.

\subsection{Strengthen Monitoring and Enforcement for Industrial Pollution}

Despite recent and significant efforts to increase staffing, resources, and capacity of local authorities to monitor the behavior and environmental performance of industrial facilities, the monitoring system remains weak. While increasing capacity may contribute to alleviating this weakness, other important issues need to be addressed:

- The rights and responsibilities of pollution control inspectors should be clearly identified, particularly in the case of industrial estates that have regularly barred entry to pollution control inspectors.
- There should be a clear set of self-reporting requirements for industrial facilities, along with administrative penalties for lack of self-reporting, and stiff penalties for knowingly reporting wrong or false information.

- There should be significant effort to increase the number of accredited laboratories that can provide sampling and analysis to industrial facilities to fulfill their self-reporting requirements. This goes hand in hand with the need for a credible system of laboratory certification, including criteria, fees, and penalties for lack of compliance with the certification requirements. The laboratories of the Departments of Natural Resources and Environment should not be allowed to be contracted by industrial facilities for purposes of fulfilling their self-reporting requirements, And the private sector should also be allowed to enter this field of activity.

- Data management and analysis is crucial for assessing and effectively using the information and improves environmental quality in a cost-effective manner. Currently, the collected information is rarely used for such decisionmaking purposes as the effective targeting of monitoring activities (e.g., which factories to inspect or which factories appear to be misreporting or violating standards). Without strong data management and analysis, the collected information cannot be used productively for monitoring and enforcement purposes.

- Improved monitoring should be accompanied by strong enforcement. They work in tandem to create incentives for pollution prevention and control. While raising existing level of fines is justified, for noncompliance of environmental regulations, fines should not be limited to their conventional forms (such as administrative or civil fines). In many cases such fines will be either too large or too small to set the right incentives. The concept of penalties should be considerably broadened to include (among other possibilities) the public disclosure of inadequate environmental performance; reduced or limited access to capital markets (unless such access would facilitate investment for pollution prevention or control purposes); and reduced or limited access to public sector contracting. 
Finally, a properly designed benchmarking system and disclosure of environmental performance by local authorities, accompanied with a system of rewards, could be effective in shifting attention to environmental quality at local levels. ${ }^{78}$

\subsection{Rationalize Expenditure for Pollution Management and Control}

The recent commitment to devote 1 percent of budget expenditures to environmental protection activity, followed with the adoption of Decision No. 70, offers new opportunity to set in place a comprehensive tracking system intended to address the inefficiency in expenditure allocation and management of the industrial sector. Particular attention should be given to setting up such a system:

- There should be a systematic and comprehensive collection of data on environmental protection activity and pollution abatement and control expenditures on an annual basis. Such data should form the basis of reporting, monitoring, and priority setting. This accounting and reporting activity may be directed by the Ministry of Finance and implemented by the Ministry of Natural Resources and Environment in collaboration with the General Statistics Office and other state agencies and organizations with environment responsibilities.

- The overall financial reporting system should include a separate budget line for environmental expenditures in general and for pollution control expenditures in particular, for state agencies and enterprises.

- The analysis of environmental protection activity and pollution abatement and control expenditures and linkages to environmental priorities should be made a standard component of the MONRE annual report on the state of the environment, and of line ministry and local government reports on state-owned enterprises.

- Public accessibility to environmental protection activity and pollution abatement and control expenditures data and information should be broadened, particularly for purposes of policy analysis related to environmental management and sustainable development.

78. China's State Environmental Protection Agency is currently piloting the implementation of such a benchmarking system. Indonesia has also piloted a similar program known as Bangun Praja. 


\section{BIBLIOCRAPHC REFERENCES}

ADB (Asian Development Bank). 2005. Socialist Republic of Vietnam - Country Environmental Analysis, ADB, Hanoi, Vietnam.

American Conference of Governmental Industrial Hygienists.1999. Guide to Occupational Exposure Values - 1999, Cincinnati, ACGIH.

CEMA, 2006. Draft Inter-Ministerial Circular on Guidelines for 135 Program - Second Phase 2006-2010, CEMA, Hanoi, Vietnam.

Center of Occupational and Environmental Health (COEH), 2005. The $2^{\text {nd }}$ International Scientific Conference on Occupational and Environmental Health - the Book of Abstracts, COEH - Vietnam Association of Occupational Health, Hanoi, Vietnam.

Center of Occupational and Environmental Health (COEH). 2004. Characteristics of Agricultural Production Techniques in the Mekong Delta: a Medical Survey, COEH- Vietnam Association of Occupational Health, Hanoi, Vietnam.

Communist Party of Vietnam, 2006. Orientation and Tasks in 5-Year Social- Economic Development 2006-2010, Report to the Xth Congress, CPV, Hanoi, Vietnam.

Consultancy Service and Technology Development Company for Natural Resources and Environment (TECOS). 2005. Vietnam Poverty and Environment Nexus Study Phase II, TECOS, Hanoi, Vietnam.

Dang Kim Chi, Nguyen Ngoc Lan, Tran Le Minh. 2005. Craft Villages in Vietnam and Environment, Science and Technical Publishing House, Hanoi, Vietnam.

Dasgupta, S., B. Laplante, and C. Meisner. 1998. Accounting for Toxicity in Pollution Control: Does it Matter? World Bank Policy Research Working Paper No. 2002. World Bank: Washington DC. Available at: http://econ.worldbank. org/docs/887.pdf

Dasgupta, S., B. Laplante, H. Wang, and D. Wheeler. 2002. Confronting the Environmental Kuznets Curve. Journal of Economic Perspectives, 16 (1): 147-168.

Do Thanh Bai. 2005. Management and Policy Review of Environmental management - Situation Analysis Study ob Chemical Safety in Vietnam, SEMLA Program, MONRE, Hanoi, Vietnam.
Fuglsang, Karsten. 2005. Environmental Information and Reporting, Mission Report, DANIDA, Hanoi, Vietnam.

General Statistics Office (GSO). 2005. Statistical Yearbook 2004, GSO, Hanoi, Vietnam.

General Statistics Office (GSO). 2005. The Situation of Enterprises Through the Results of Surveys Conducted in 2003, 2004, 2005, GSO, Hanoi, Vietnam.

Government of Vietnam. 2005. The Key Issues in 2006 Social - Economic Development, Report to National Assembly, 18 October 2005, Government of Vietnam, Hanoi, Vietnam.

Gwilliam, Ken, Masami Kojima, and Todd Johnson. 2005. Reducing Air Pollution from Urban Transport, World Bank, Hanoi, Vietnam.

Hettige, M., P. Martin, M. Singh, and D. Wheeler. 1995. The Industrial Pollution Projection System, World Bank Policy Research Working Paper No. 1431, World Bank: Washington, DC.

Holger Peterson. 2005. Environmental Information and Reporting, Mission Report, DANIDA, Hanoi, Vietnam.

Horvath, A., C. T. Hendrickson, L. B. Lave, F. C. McMichael, and T-S. Wu. 1995. Toxic Emissions Indices for Green Design and Inventory, Environmental Science \& Technology, 29, 2: 86A-90A.

Japan International Cooperation Agency (JICA). 2004. The Study on Artisan Craft Development Plan for Rural Industrialization in the Socialist Republic of Vietnam, JICA, Hanoi, Vietnam.

Korea Environment Institute. 2005. Vietnam - Regional Environmental Management for Traditional Villages, World Bank, Hanoi, Vietnam.

Laplante, B., and C. Meisner. 2001. Estimating Conventional Industrial Water Pollution in Thailand. Mimeo. World Bank: Washington DC. Available at: http://www.worldbank.org/ nipr/Thailand/EstimatingConventionallndustrialWater.htm.

Laplante, B., and K. Smits. 1998. Estimating Industrial Pollution in Latvia. Mimeo. World Bank: Washington DC. 
MARD (Ministry of Agriculture and Rural Development). 2005. The 5-Year Plan for Agricultural and Rural Sector - Period 2005-2010, MARD, Hanoi, Vietnam.

MARD. 2005. The Proposal to Government on Environment Protection Project for Handicraft Villages and livestock Clusters, No.3018, 21 November 2005, MARD, Hanoi, Vietnam.

MARD. 2004. Decision on Licensing for Discharging Waste Water into Irrigation System, No.56/2004/QD-BNN, 01 November 2004, MARD, Hanoi, Vietnam.MOC (Ministry of Construction). 2005. Northern Focal Economic Zone - Regional Construction Planning Issues, MOC, Hanoi, Vietnam.

MOI (Ministry of Industry). 2005. Environmental Report on Vietnam's Industries, Institute for Industry Strategy and Policy, MOI, Hanoi, Vietnam.

MOI. 2004. Approval of Plastic Industry Development Plan to 2010, Decision11/2004, 17 February 2004, MOI, Hanoi, Vietnam.

MOI. 2004. Approval Vegetable Oil Industry Development Plan to 2010, 8 March 2004, MOI, Hanoi, Vietnam.

MONRE (Ministry of Natural Resources and Environment). 2005. Five-YearPlan for Natural Resources and Environment Sector 2006-2010, MONRE, Hanoi, Vietnam.

MONRE. 2005. Environmental Information and Reporting Project - Brief Position Paper, VEPA/MONRE, Hanoi, Vietnam.

MONRE. 2005. National Environment Report For Biodiversity, MONRE, Hanoi, Vietnam.

MONRE. 2005. National Environnent Report 2005, MONRE, Hanoi, Vietnam.

MONRE. 2001. State of the Environment Report 2001, MONRE, Hanoi, Vietnam.

MPI (Ministry of Planning and Investment). 2005. New Approach in Poverty Reduction, Sharing Project, MPI, Hanoi, Vietnam.

MPI, 2005. Regulation on the Activities of Office of Focal Economic Zones Steering Committee, Decision 837/QDBKH, April 2005, MPI, Hanoi, Vietnam.
MPI. 2005. 2005 Progress Report and 2006 Work plan of Northern Focal Economic Zone, MPI, Hanoi, Vietnam.

MPI. 2005. 2005 Progress Report and 2006 Workplan of Central Focal Economic Zone, MPI, Hanoi, Vietnam.

MPI. 2005. 2005 Progress Report and 2006 Workplan of Southern Focal Economic Zone, MPI, Hanoi, Vietnam.

MPI. 2005. 2005 Progress Report and 2006 Workplan of Steering Committee of Focal Economic Zones, SC of FEZ, MPI, Hanoi, Vietnam.

MPI. 2005. Planning Renovation during Building and Improving Mechanism of Market-Oriented Socialism Workshop Documents, MPI, Hanoi, Vietnam.

MPI. 2000. Three Focal Economic Zones Development Progress and its Coordination with other Regions, MPI, Hanoi, Vietnam.

MPI and JICA. 2004. To Strengthen the Competitiveness of Vietnamese Industries in the Context of Formulation of Socio-Economic development Plan 2005-2010, MPI, Hanoi, Vietnam.

Nguyen Danh Son, and Nguyen Ngoc Sinh. 2005. The Use of Economic Instruments in Environmental Management in Vietnam, SEMLA Project, MONRE, Hanoi, Vietnam.

Nguyen Thanh Hung, and Nguyen Thanh Ha. 2004. Environment issues in WTO and ASEAN (AFTA) Documents and Solution for Trading Sector in Vietnam, Ministry of Trade, Hanoi, Vietnam.

People's Committee of Bac Ninh Province. 2005. State of the Environment Report for 2005, Department of Natural Resources and Environment, Bac Ninh, Vietnam.

People's Committee of Binh Duong Province. 2005. State of the Environment Report of Binh Duong province for 2005, Department of Natural Resources and Environment, Binh Duong, Vietnam.

People's Committee of Dong Nai Province. 2005. State of the Environment for 2005, Summary Report, Department of Natural Resources and Environment, Bien Hoa, Vietnam.

People's Committee of Hanoi City. 2005. The Proposal on Applying Water Monitoring Software in Hanoi, No. 4042/ TNMTND-QLMT, 11 October 2005, Department of Natural Resources and Environment, Hanoi, Vietnam. 
People's Committee of Ho Chi Minh City. 2005. State of the Environment Report of Ho Chi Minh City for 2004-2005, Department of Natural Resources and Environment, Ho Chi Minh City, Vietnam.

People's Committee of Phu Tho Province. 2005. State of the Environment Report of Phu Tho province for 2005, Department of Natural Resources and Environment, Viet Tri, Vietnam.

People's Committee of Quang Nam Province. 2005. State of the Environment Report of Quang Nam province for 2005, Department of Natural Resources and Environment, Tam Ky, Vietnam.

People's Committee of Thai Nguyen Province. 2005. State of the Environment Report of Thai Nguyen province for 2004-2005, Department of Natural Resources and Environment, Thai Nguyen, Vietnam.

People's Committee of Thanh Hoa Province. 2005. State of the Environment Report of Thanh Hoa province for People's Committee of Phu Tho Province, 2005 - State of the Environment Report of Phu Tho province for 2005, Department of Natural Resources and Environment, Viet Tri, Vietnam.

People's Committee of Hanoi City. 2003. State of the Environment Report of Hanoi City for 2003, Department of Natural Resources and Environment, Hanoi, Vietnam.

Pham Ngoc Dang, Le Trinh, and Nguyen Quynh Huong. 2004. Environmental Assessment, Forecast and Environmental Protection Proposals in two Northern and Southern Focal Economic Zones, Construction Publishing House, 2004, Hanoi, Vietnam.

Pham Van Ninh. 2005. Feasibility Study of Draft List of Indicators for the Environmental Subject: Marine and Coastal Water, Environmental Information and Reporting project, MONRE, Hanoi, Vietnam.

Prime Minister. 2005. Approval National Plan for Environment Pollution Monitoring to 2010, Decree No.328/2005/QDTTg, 12 December 2005, Prime Minister, Hanoi, Vietnam.

Prime Minister. 2005. Approving the National Plan for Pollution Monitoring to 2010, Decree No. 328/2005/QD-TTg, 12 December 2005, Hanoi, Vietnam.
Prime Minister. 2005. Approval Amended Development Strategy of Vietnam Ship Industry General Company in 2005-2010 and Orientation to 2020, No.1106/QD-TTg, 18 October 2005, Prime Minister, Hanoi, Vietnam.

Prime Minister. 2005. Approval Chemical Industry Development Strategy to 2010 and Vision to 2020, No.207/2005/QD-TTg, 18 August 2005, Prime Minister, Hanoi, Vietnam.

Prime Minister. 2005. Decision on Administrative Fine to the Violations in Irrigation System Operation and Protection, Decree 140/2005/ND-CP, 11 November 2005, Hanoi, Vietnam.

Prime Minister. 2004. The Main Orientation in Social-Economic Development of Northern Economic Zone to 2010 and Vision to 2020, Decree 145/2004, August 2004, Prime Minister, Hanoi, Vietnam.

Prime Minister. 2004. The Main Orientation in Social-Economic Development of Southern Economic Zone to 2010 and Vision to 2020, Decree 146/2004, August 2004, Prime Minister, Hanoi, Vietnam.

Prime Minister. 2004. The Main Orientation in Social-Economic Development of Central Economic Zone to 2010 and Vision to 2020, Decree 148/2004, August 2004, Prime Minister, Hanoi, Vietnam.

Prime Minister. 2004. Approval of Electricity Industry Development Strategy in 2004-2010 and Vision to 2020, No.176/2004/QD-TTg, 5 October 2004, Prime Minister, Hanoi, Vietnam.

Prime Minister. 2003. Approving the Plan for Thoroughly Handling Establishments Which Cause Serious Environmental Pollution, Decree 64/2003/QD-TTg, 22 April 2003, Prime Minister, Hanoi, Vietnam.

Prime Minister. 2002. Approval of Mechanic Industry Development Strategy to 2010 and Vision to 2020, No.186/2002/QD-TTg, 26 December 2002, Prime Minister, Hanoi, Vietnam.

Socio-Economic Development Center (SEDEC). 2005. Environment and Poverty Linkages in the Cau River Basin, SEDEC, Hanoi, Vietnam. 
Swanson, M., G. A. Davis, L. E. Kincaid, T. W. Schultz, J. E. Bartmess, S.L. Jones, and E. L. George. 1997. A Screening Method for Ranking and Scoring Chemicals by Potential Human Health and Environmental Impacts, Environmental Toxicology and Chemistry, 16, 2: 372-383.

VEPA and IUCN. 2005. Review on Wetland After 15 Years Participating RAMSAR Convention, VEPA, Hanoi, Vietnam.

WHO. 1997. Health and Environment in Sustainable Development: Five Years After the Earth Summit WHO/ EHG/97-8. Geneva: World Health Organization.

WHO. 2006. WHO Air Quality Guidelines for Particulate Matter, Ozone, Nitrogen Dioxide and Sulfur Dioxide, Global Update 2005, Summary of Risk Assessment. Copenhagen: World Health Organization. Available at: http://www.who.int/phe/air/agg2006execsum.pdf.

World Bank. 2006. GEF - Thailand, China, Vietnam Livestock Waste Management in East Asia Project, GEF, Project Document, World Bank, Hanoi, Vietnam.

World Bank, 2005. Vietnam - Poverty and Environment, World Bank, EASEN, Hanoi, Vietnam.

World Bank-KEl-MONRE. 2004. Report on Socio-Economic Development and Environmental Pollution in Vietnamese Traditional Craft Villages - Challenges and Opportunities for Environmental management, World Bank, Hanoi, Vietnam.

Vietnam Cleaner Production Center. 2005. Situation Analysis Paper on Cleaner Production in Vietnam, Vietnam Cleaner Production Center, Hanoi, Vietnam.

Vietnam Government. 2003. Functions and Organization of Ministry of Transport, Decree 34/2003/ND-CP, Hanoi, Vietnam.

Vietnam Railways General Company. 2005. Five-Year Development Plan 2006-2010 of Vietnam Railways General Company, Hanoi, Vietnam.

UNIDO. 2000. Rural Industrial Development in Vietnam Strategy for Employment Generation and Regional Balanced Development, MARD, Hanoi, Vietnam.

US-ASIA Environmental Partnership. 2002. Before the Clouds Gather: Protecting Clean Air in Vietnam, US-AEP, Hanoi, Vietnam. 


\section{ANMEX A. METHODOLOGY}

\section{The Industrial Pollution Projection System (IPPS)}

IPPS is a modeling system which combines data from industrial activity (such as production and employment) with data on pollution emissions to calculate pollution intensity factors (or coefficients), i.e. the level of pollution emissions per unit of industrial activity. The IPPS is the result of a 1995, collaborative research effort between the Center for Economic Studies of the US Census Bureau, the US Environmental Protection Agency and the Policy Research Department of the World Bank resulted in the development of the Industry Pollution Projection System (IPPS) with the objective to help environmental protection agencies, particularly in low and middle income countries, to address the need for data on pollution emission that would allow the design of costeffective regulation for pollution control and abatement (Hettige et al. 1995).

Pollution intensities have initially been calculated with data available in the United States from the U.S. Manufacturing Census and the United States Environmental Protection Agency (USEPA). The basic calculation took manufacturing information on output value, value-added and employment and matched this with the USEPA database on pollution releases, on a plant-by plant basis. Pollution intensities were then calculated as the total amount of releases divided by the manufacturing indicator (i.e. output value, value-added or employment). In the case of the employment-based indicator, that figure is the number of $\mathrm{kg}$ of pollutant per unit of employment. IPPS has pollution intensities using several different manufacturing measures, however the one retained for this study is the employmentbased pollution intensity since it has been shown to be much more stable across different technologies and across both developed and developing countries (Dasgupta et al. 2002).
The USEPA contains emissions information for a number of pollutants and chemical substances known to be harmful to both human health and the environment. IPPS coefficients are available for the following list of pollutants:

\section{Air pollutants:}

- sulfur dioxide $\left(\mathrm{SO}_{2}\right)$;

- nitrogen dioxide $\left(\mathrm{NO}_{2}\right)$;

- volatile organic compounds (VOC); and

n particulate matter: both total suspended particulates (TSP) and particulate matter of size less than 10 microns $\left(\mathrm{PM}_{10}\right)$.

\section{Water pollutants:}

n Biological oxygen demand (BOD); and

- Total suspended solids (TSS).

IPPS also includes pollution intensities for over 240 priority chemicals and metals released to air, water, and land. ${ }^{1}$ Listed below are some of the chemicals known to be toxic to human health and metals known to be bio-accumulative:

- Chemicals: Benzene, chloroethane, chloromethane, toluene and zylene;

netals: Antimony, arsenic, asbestos, beryllium, cadmium, chromium, copper, cyanide, lead, mercury, nickel, thallium and zinc.

For each of the air and water pollutants and the 240 toxic chemicals and metals, IPPS provides a lower bound value for the pollution intensity coefficients, an upper bound value, and an inter-quartile mean value. For the purpose of this study, estimates of pollution load are based on the lower bound value of pollution intensity. It was decided to adopt the more conservative measure of pollution intensity. Therefore, pollution release estimates presented in this report are to be interpreted as under-estimates of the actual pollution releases. However, in the context of this study, and for priority setting in general, what matters most are the relative rankings of one sector or area over another.

1. The TRI requires firms to report their releases of chemicals known to be toxic and metals known to be bio-accumulative in each of the following categories: (1) Fugitive or non-point air emissions; (2) stack or point air emissions; (3) discharges to streams or receiving water bodies; (4) underground injection on-site; (5) release to land on-site; (6) wastewater discharges to publicly-owned treatment works; and (7) transfer to off-site facilities for treatment, storage or disposal. These seven categories are grouped into 3: air, water, and land. 


\section{Methods for assessing industrial pollution toxicity and hazard}

There are two related terms which are especially important in industrial pollution management - "toxic substances" and "hazardous substances". These terms are used interchangeably but do have a slightly different meaning. The first relates broadly to harmful substances in the environment while the term "hazardous substances" relates more to their affect on people. Pollutants in Vietnam which are toxic and hazardous need to be identified, sourced and managed as a matter of the highest priority.

"Toxic substances" or pollutants are chemical and metal contaminants in the environment that harm plants, animals, fish and humans. "Toxicity" is the degree to which a substance can harm humans, animals or natural systems. The toxicity of a chemical depends on many factors, including concentration (i.e. the amount in a unit area), chemical and physical form, as well as its persistence (i.e. how long it stays in the environment). The chemical and physical properties of a receiving water body, land or air, combined with the type and life stage of the living resources exposed to the chemical, also affect a contaminant's toxicity.

"Hazardous substance" is a term usually relating to the effect of industrial chemicals on human health. It is a substance which has the potential to harm the health or safety of persons in or outside of the workplace. Hazardous substances are:

- harmful/toxic - causing transient or permanent damage to body functions

- corrosive - causing damage to living tissue

- irritant - causing local irritation to living tissue

- sensitizing - causing an allergic reaction

- carcinogenic - causing cancer

- mutagenic - causing genetic damage

- substances toxic to human reproduction.

It is well-known that chemicals and metals possess widely varying characteristics in terms of their potential impact to human health and the environment in general. Hence, measuring the relative toxicity of a particular substance may prove to be important when assessing the level of risk when an individual is exposed to such substance. A second important determinant of risk is exposure, which is a function of the concentration of the particular substances and the duration of exposure to that concentration. For any given period of time, higher concentrations can lead to higher risk factors for the individual. Similarly, for any given level of concentration, longer periods of exposure can lead to higher risk factors. Both toxicity and exposure are important in assessing risk.

To factor toxicity into the analysis of IPPS pollution loads, estimates are weighted by a relative toxicity factor or Threshold Limit Values (TLV) produced by an internationally recognized source (American Conference of Governmental Industrial Hygienists, 1999). These toxicity factors are a culmination of epidemiological evidence and occupational health and safety standards typically adopted throughout the US and the world. The calculation procedure essentially multiplies the estimated pollution load by the relative toxicity factor (TLV) of the substance to yield a toxicity-weighted pollution load. For example, if a particular substance were more toxic, the pollution load would receive a greater weight than if the substance were relatively benign. Thus substances that are relatively more toxic would rank higher owing to weighting scheme. To calculate the relative hazard risk, the pollution load estimates are also categorized into three ranges of acute exposure hazard using lethal concentration, $\mathrm{LC}_{50}$, and lethal dose, LD Lo , values (Horvath et al., 1995; Swanson et al., 1995). These measures form the basis of epidemiological impact studies in evaluating the potential risk to human life. In this study, each chemical in the database was classified as a (1) high hazard, (2) moderate hazard, or (3) low hazard according to its $L C_{50}$ and $L D_{50}$ value and then aggregated up to the plant level and summarized at the provincial, commune and sector level.

\section{The industry census database}

The key piece of information required to calculate pollution load in Vietnam is the information on the scale of manufacturing activity. The data source used in this exercise is the 2004 Enterprise Census from the General Statistical Office (GSO) of the Ministry of Planning and Investment (MPI). Enterprise 
information is collected according to the Vietnam Standard Industrial Classification (VSIC) system², which is based on the International Standard Industrial Classification (ISIC) system (Revision 3.1). ${ }^{3}$ In the 2004 Census used as a basis for this report, there were over 90,000 recorded enterprises spanning 14 industrial sectors. ${ }^{4}$ Since the interest here is to estimate industrial pollution from manufacturing activities, the sample is restricted to the manufacturing sector data within the Census. This includes 131 subsectors at the VSIC-4 unit of analysis. The GSO Census of 2004 covers 20,444 firms in the manufacturing sector, and 2,833,615 workers. This represented nearly 23 percent of all enterprises in the GSO 2004 Census, and 53 percent of all employment.

\section{Validation of GSO survey}

One noted limitation of the GSO data set is that some of the observations are for the headquarters of a company that has operations in other locations. To test the extent to which this was true, a field study was conducted by selecting the top two communes in each of the top 10 provinces in terms of the estimated pollution load by IPPS. Then the top 2-3 most polluting factories and their commune location were identified. Field operators then placed a phone call to the factory to substantiate its location. In the case that a factory could not be contacted, a call to the relevant provincial Department of Natural Resources and Environment was placed. Since the factories were serious polluters, in most cases the Department of Natural Resources and Environment's were aware of the factories and could pin point their location. This was not always the case. During informal discussions, it was noted that some of the most seriously polluting factories were not in the communes identified. The addresses given were only the headquarters for administration purposes.
The degree of bias this phenomena introduces is unknown, however the magnitude of this bias diminishes with greater aggregation of analysis. At the provincial level it may not be a concern at all since most operations, including the headquarters may co-locate in the same province. However at levels of aggregation smaller than the commune level results are not fully reliable. Field observations will play a critical role in the follow-up to this study and to future monitoring activities. The study should also lead to further discussions with the General Statistics Office on improving the coverage of the census and the method of collection so that satellite plant locations are fully and accurately accounted for in the annual roster. These suggestions and others are described more fully in subsequent chapters on the way forward.

\section{Method of validation for estimation}

One common question that arises when IPPS is used in a developing country context such as Vietnam is how realistic is it to use coefficients derived from data in the United States? The answer is two fold. In the absence of detailed information on pollution emissions, IPPS serves as a first-order approximation until such time as locally monitored information can be substituted into the model to make it country-specific. Another reason for using IPPS lies in understanding whether Vietnamese industrial technology is well represented by the underlying technology reflected in IPPS. The coefficients derived for IPPS were based on 1987 emissions profiles for over 20,000 plants in the US. Many existing industrial operations in Vietnam use technologies over 15-20 years old similar to those operating in the US in the late 1980's and early 90s (although, in some sectors such as seafood processes, technologies are changing rapidly). Most important, the

2. Data are collected at the 6-digit VSIC level.

3. The United Nations classification of industry - ie the International Standard for Industry Classification (ISIC) is adopted by all countries. The Vietnam system of industrial classification follows the ISIC Revision 3.1. The detailed descriptions can be found on the UN Statistics Office Website: http://unstats.un.org/unsd/cr/ registry/regcst.asp

4. Agriculture, forestry and fishing; mining and quarrying; manufacturing; electricity, gas and water supply; construction; wholesale and retail trade; hotels and restaurants; transport, storage and communications; financial intermediation; real estate, renting and business activities; public administration and defense; education; health and social work; and other community, social and personal service activities. 
coefficients used in this study are lower bounds - ie resulting in the most conservative pollution estimates based on the US technology inherent in the coefficient structure.

In the case of Vietnam, some monitored information on pollution is available however it is not collected on a systematic and comprehensive basis and does not cover as many pollutants or sectors as in the IPPS. The purpose of this section is to compare the relative ranking of pollution load for provinces and sectors using real Vietnamese observed coefficients with those estimated by IPPS. This provides some evidence to the question - does the underlying Vietnamese technology concord well with the technology inherent in the US-based IPPS coefficients? To test this proposition, pollution coefficients for BOD and TSS were obtained from the CTC Vietnam ${ }^{5}$ and from the Vietnam-Canada Environment Project. Since the CTC database of coefficients included coefficients for 54 sectors measured in terms of manufacturing employment, this facilitated a comparison with the IPPS coefficients used for this exercise (employment-based coefficients). Rank correlation coefficients were calculated between estimated BOD and TSS loads using both CTC and IPPS coefficients. The results suggest that at the provincial level the correspondence is high, while among sectors it is lower. However, the differences between sector estimates are not statistically significant. In addition, since only 54 sectors were comparable this may explain the lower correlation.

\section{Analysis of specific air pollutants}

\section{Nitrogen Dioxide $\left(\mathrm{NO}_{2}\right)$}

Nitrogen dioxide is a reddish brown, highly reactive gas that is formed in the ambient air through the oxidation of nitric oxide (NO). Motor vehicles and, to a lesser extent, coal-fired generators, are the major sources of nitrogen oxides. Shortterm exposures to low levels of $\mathrm{NO}_{2}$ may lead to changes in airway responsiveness and lung function in individuals with preexisting respiratory illnesses. These exposures may also increase respiratory illnesses in children. Long-term exposures to $\mathrm{NO}_{2}$ may lead to increased susceptibility to respiratory infection and may cause irreversible alterations in lung structure. $\mathrm{NO}_{x}$ also contributes to a wide range of environmental effects. Increased nitrogen inputs to terrestrial and wetland systems can lead to changes in plant species composition and diversity. Similarly, direct nitrogen inputs to aquatic ecosystems can lead to eutrophication. Nitrogen, alone or in acid rain, also can acidify soils and surface waters. Acidification of soils causes the loss of essential plant nutrients and increased levels of soluble aluminum that are toxic to plants. The damage caused by acid rain deposition occurs in environments that cannot tolerate acidification. Many species of fish, insects, aquatic plants and bacteria develop reproduction difficulties. Some even die. The decline in the population of any of these aquatic organisms affects the food chain. Dwindling populations of insects and small aquatic plants and animals are especially serious because the entire food chain is affected.

The total $\mathrm{NO}_{2}$ pollution load generated in Vietnam from manufacturing is estimated to be 655,899 tons annually (Table A.1). This represents 18.5 percent of all air pollution (ie from the five conventional air pollutants and two categories of chemicals and metals). In terms of total load it ranks $4^{\text {th }}$ highest. In terms of relative hazard it ranks 3. Current WHO guideline values for $\mathrm{NO}_{2}$ are a 1-hour level of $200 \mu \mathrm{g} / \mathrm{m}^{3}$ and an annual average of $40 \mu \mathrm{g} / \mathrm{m}^{3}$ (World Health Organization, 2006). Although this estimated load for Vietnam would pose a serious risk if those exposed were subject to high sustained concentrations, relatively speaking it is a low priority overall.

5. http://www.ctcgroupe.com/en/locations/ctc_vietnam.php 
Table B.1. National estimates of air pollution load and evaluation criteria

\begin{tabular}{|lcccc|}
\hline & $\begin{array}{c}\text { Load } \\
\text { (tons/ } \\
\text { year) }\end{array}$ & $\%$ & $\begin{array}{c}\text { Ordered } \\
\text { load } \\
\text { rank }\end{array}$ & $\begin{array}{c}\text { Hazard } \\
\text { rank }\end{array}$ \\
\hline $\mathrm{NO}_{2}$ & 655,899 & 18.52 & 4 & 3 \\
\hline $\mathrm{SO}_{2}$ & $1,117,757$ & 31.56 & 1 & 3 \\
\hline VOC & 267,706 & 7.56 & 5 & 2 \\
\hline TSP & 673,842 & 19.02 & 3 & 2 \\
\hline PM & 682,494 & 19.27 & 2 & 2 \\
\hline Chemicals to air & 143,569 & 4.05 & 6 & 1 \\
\hline Metals to air & 960 & 0.03 & 7 & 1 \\
\hline
\end{tabular}

Hazard ranking indexed as: 1 = high priority, 2 = medium priority, $3=$ low priority.

\section{Sulfur Dioxide $\left(\mathrm{SO}_{2}\right)$}

Sulfur dioxide belongs to the family of sulfur oxides $\left(\mathrm{SO}_{x}\right)$ gases. These gases are formed when fuel containing sulfur (mainly coal and oil) is burned at power plants and during metal smelting and other industrial processes. Generally, the highest monitored concentrations of $\mathrm{SO}_{2}$ are recorded near large industrial facilities. Some of the major sources of sulfur dioxide emissions are non-ferrous metal smelters and coalfired generators. High concentrations of $\mathrm{SO}_{2}$ can result in temporary breathing impairment for asthmatic children and adults. Other effects that have been associated with longerterm exposures to high concentrations of $\mathrm{SO}_{2}$ include aggravation of existing cardiovascular disease, respiratory illness, and alterations in the lungs' defenses. Elderly, children, and individuals with heart or lung disease may be most affected by exposure to $\mathrm{SO}_{2}$. Together, $\mathrm{SO}_{2}$ and nitrogen oxide $\left(\mathrm{NO}_{\mathrm{x}}\right)$ are the major precursors to acidic deposition (acid rain), which is associated with the acidification of soils, lakes, and streams and accelerated corrosion of buildings and monuments.
Total $\mathrm{SO}_{2}$ pollution load from manufacturing is estimated to be approximately 1,117,757 tons per year (Table A.1), representing the highest share among all air pollutants at 31.6 percent. The $\mathrm{WHO}$ guideline values for $\mathrm{SO}_{2}$ are a 10-minute level of $500 \mu \mathrm{g} / \mathrm{m}^{3}$ and a 24-hour average of $20 \mathrm{\mu g} / \mathrm{m}^{3}$ (World Health Organization, 2006). ${ }^{6}$ Although $\mathrm{SO}_{2}$ ranks high on load, it is relatively low in hazard ranking since in low concentrations $\mathrm{SO}_{2}$ does not pose a significant health risk. However, there could be areas where it is high enough to pose a significant health risk (e.g. industrial parks). But these may be few and far apart.

\section{Volatile Organic Compounds (VOCs)}

VOCs are classified as any organic compound that participates in atmospheric photochemical reactions. VOCs are emitted from diverse sources, including automobiles, chemical manufacturing facilities, pharmaceuticals, refrigerants, drycleaners, paint shops and other commercial and residential sources that use solvent and paint. Concentrations of many VOCs are consistently higher indoors (up to ten times higher) than outdoors. VOCs typically are industrial solvents, such as trichloroethylene, fuel oxygenates, such as methyl tert-butyl ether (MTBE), or by-products produced by chlorination in water treatment, such as chloroform. They are often components of petroleum fuels, hydraulic fluids, paint thinners, and dry cleaning agents and are common ground-water contaminants. Exposures are often associated with an odor while at other times there is no odor. Both can be harmful. There are thousands of different VOCs produced and used in our daily lives, even within households. Many products emit or "off-gas" VOCs such as: benzene, toluene, methylene, chloride, formaldehyde, xylene, ethylene glycol, texanol and 1,3-butadiene. VOC emissions also form low-level ozone through complex chemical reactions with $\mathrm{NO}_{x}$ in the presence of sunlight. Ground-level ozone is a respiratory toxicant.

Health effects depend on the specific composition of the VOCs present, the concentration and the length of exposure. High concentrations of some compounds which may occur

6. The new $\mathrm{WHO}$ guidelines do not specify annual ambient concentrations for all pollutants. 
when working with materials or processes that emit VOCs could have serious health effects. These should be considered under the effects of the specific component. General effects of lower concentrations include eye, nose, and throat irritation; headaches, loss of coordination, nausea; damage to liver, kidney, and central nervous system. Some VOCs can cause cancer in animals; some are suspected or known to cause cancer in humans. Build-up of VOCs in indoor environments have been associated with the 'sick building syndrome'.

The pollution load of all VOCs from manufacturing is estimated to be 267,706 tons per year (Table A.1), representing the smallest share among the conventional air pollutants with 7.6 percent but is ranked 5th for load among the seven air pollution categories in this study. Since VOCs comprise a variety of different compounds and substances, the WHO does not provide guideline values for VOCs. Some VOCs are low in hazard while others pose significant exposure risks. In this particular case it is difficult to attach a hazard ranking, so initially it is given a 2 or moderate priority. It is suggested that environmental authorities conduct field tests of sectors in areas where VOCs are suspect and confirm whether the constituents of VOCs are high or low hazard risk.

\section{Particulate Matter (PM)}

Particulate matter (PM) includes dust, dirt, soot, smoke and liquid droplets directly emitted into the air by sources such as factories, power plants, cars, construction activity, fires and natural wind blown dust. Particles formed in the atmosphere by condensation or the transformation of emitted gases such as $\mathrm{SO}_{2}$ and $\mathrm{VOC}$ are also considered particulate matter. Particulate matter is a mixture of particles that can adversely effect human health, damage materials and form atmospheric haze that degrades visibility. PM is usually divided up into different classes based on size, ranging from total suspended matter (TSP) to PM-10 (particles less than 10 microns in aerodynamic diameter) to PM-2.5 (particles less than 2.5 microns). In general, the smallest particles pose the highest human health risks. PM exposure can affect breathing, aggravate existing respiratory and cardiovascular disease, alter the body's defense systems against foreign materials, and damage lung tissue, contributing to cancer and premature death. Individuals with chronic obstructive pulmonary or cardiovascular disease, asthmatics, the elderly and children are most sensitive to the effects of PM.

The total $\mathrm{PM}_{10}$ load estimated from manufacturing is 682,494 tons per year which is 19.3 percent and ranking $2^{\text {nd }}$ in the total air pollution load (Table A.1). In the past the WHO did not provide any guideline values for $\mathrm{PM}_{10}$ since the linkages between particulate matter and mortality and morbidity outcomes were still under investigation. Over the last decade, many scientific studies have been conducted and resulted in convincing evidence of the linkage between particulate matter and respiratory disease. In October of 2006, the WHO released their first guideline values of $50 \mu \mathrm{g} / \mathrm{m}^{3}$ for the 24hour average and $20 \mu \mathrm{g} / \mathrm{m}^{3}$ as an annual mean (World Health Organization, 2006). Owning to its persistence in the environment, and the recent health evidence $\mathrm{PM}_{10}$ is ranked as moderately hazardous.

\section{Chemicals (known to be toxic)}

Many chemicals in industrial releases to air, water and land are known to be poisonous to humans, either on immediate exposure or over time, as they accumulate in human tissues. Toxic chemicals may cause damage to internal organs and neurological functions, can result in reproductive problems and birth defects, and can be carcinogenic. Quantities and length of exposure cause these effects to vary widely. The degree to which an toxic air pollutant affects a person's health depends on many factors, including the route of the exposure, quantity of pollutant, the duration and frequency of exposure, the toxicity of the chemical and a person's general health. That is the case for the 241 chemicals and metals in the IPPS database - potentially all are highly hazardous to health. For example, benzene, is a known carcinogen linked to leukemia. It is used as solvent and synthetic raw material in the chemicals, and related products, industry. Breathing in large quantities can cause headaches, vertigo, nausea and even death. The environmental fate of many of these chemicals can be labeled as quite persistent, where degradation rates are slow and if absorbed into the human body, have adverse health effects.

The estimated load presented here is a combination of chemicals that are released to air, however, it should be understood that each chemical associated with a particular 
industrial process may emit across several different media such as land or water. For this reason specific estimates for air, land and water are presented. Total chemical loads to air from manufacturing were estimated to be 143,569 tons per year or 4.1 percent of total air load (Table A.1). This only ranks $6^{\text {th }}$ in terms of load, but since it includes many substances known to be toxic these emissions are ranked as a top priority.

\section{Metals (known to be bio-accumulative)}

Bio-accumulative metals persist in the environment and accumulate in humans. This group of chemicals includes some forms of mercury, lead, and cadmium. For example, lead is readily absorbed, particularly in children, with distribution from the blood to its storage depots - bone and teeth. Both metabolism and excretion are slow, so monitoring lead levels is more straightforward using indicators located in blood, bone, and teeth. For general population exposures to mercury, methyl mercury is the form of highest concern. Measurements taken in blood, hair, and nails are viable indicators for measuring methyl mercury levels. Airborne metals are particularly hazardous to workers from an occupational health and safety standpoint. Repeated daily exposures to ambient levels that exceed epidemiological thresholds can lead to dire long-term consequences.

In addition, low concentrations of metal contaminants in air, water, soil or plants can become far more concentrated further up the food chain. Some metals can be transformed into organic forms by bacteria, increasing the risk they will enter the food chain. Bio-accumulative metals are particularly dangerous because they are dissipated very slowly by natural systems. They cause both neurological and developmental birth defects. Total metal loads to air from manufacturing were estimated to be only 960 tons per year or 0.03 percent of the total air load (Table A.1). Although this ranks last in terms of total air loads, the potential airborne hazards that many of these metals may cause make this pollution release a top priority.

\section{Water pollution}

\section{Biological Oxygen Demand (BOD)}

Microorganisms such as bacteria are responsible for decomposing organic waste in water. When organic matter such as dead plants, leaves, manure, sewage, or even food waste is present in a water supply, the bacteria will begin the process of breaking down this waste. When this happens, much of the available dissolved oxygen (DO) is consumed by aerobic bacteria, robbing other aquatic organisms of the oxygen they need to live. BOD is a measure of the oxygen used by microorganisms to decompose this waste. If there is a large quantity of organic waste in the water supply, there will also be a lot of bacteria present working to decompose this waste. In this case, the demand for oxygen will be high (due to all the bacteria) so the BOD level will be high. When BOD levels are high, DO levels decrease, since less dissolved oxygen is available in the water, and fish and other aquatic organisms may not survive. A common measure is $\mathrm{BOD}_{5}$ which is the amount of dissolved oxygen consumed in five days by biological processes breaking down organic matter.

The total estimated load of BOD from manufacturing in Vietnam was 85,402 tons per year or 11.9 percent of water pollution. This places BOD second to the other water indicator, total suspended solids. Since BOD is a measure of the organisms that decay in water, the environmental fate of these organisms is short-lived. Thus the pollution problem overall is a lower priority, relatively speaking. However, high levels of organic matter in water can lead to severe health issues such as diarrhea and other bacterial infections if left untreated. The size and flow rate of the water body dictate the assimilative capacity to absorb organic matter, as do the nature of the organic loadings. In high population density areas, such as Hanoi and Ho Chi Minh City, BOD is a significant concern. 
Table B.2. National estimates of water pollution load and evaluation criteria

\begin{tabular}{|lcccc|}
\hline Pollutant & $\begin{array}{c}\text { Load } \\
\text { (tons/ } \\
\text { year) }\end{array}$ & $\%$ & $\begin{array}{c}\text { Ordered } \\
\text { load } \\
\text { rank }\end{array}$ & $\begin{array}{c}\text { Hazard } \\
\text { rank }\end{array}$ \\
\hline B0D $_{5}$ & 85,402 & 11.86 & 2 & 3 \\
\hline TSS & 618,240 & 85.88 & 1 & 3 \\
\hline $\begin{array}{l}\text { Chemicals to } \\
\text { water }\end{array}$ & 16,018 & 2.23 & 3 & 1 \\
\hline Metals to water & 199 & 0.03 & 4 & 1 \\
\hline
\end{tabular}

Hazard ranking indexed as: 1 = high priority, 2 = medium priority, $3=$ low priority.

\section{Total Suspended Solids (TSS)}

Total suspended solids (TSS) are solids in water that can be trapped by a filter. It is a measure of the mass of fine inorganic particles suspended in the water. TSS can include a wide variety of material, such as silt, decaying plant and animal matter, sediments from soil erosion, industrial wastes, and sewage. High concentrations of TSS can block light from reaching submerged vegetation, slowing down photosynthesis. This causes less dissolved oxygen to be released into the water by plants. If light is completely blocked from bottom dwelling plants, the plants will stop producing oxygen and will die. As the plants are decomposed, bacteria will use up even more oxygen from the water. High TSS can also cause an increase in surface water temperature, because the suspended particles absorb heat from sunlight. This can cause dissolved oxygen levels to fall even further. Suspended solids can also clog fish gills, reduce growth rates, decrease resistance to disease, and prevent egg and larval development.

TSS loads from manufacturing estimated by IPPS were substantial at 618,240 tons per annum or 85.6 percent of total water pollution loadings. In small concentrations the loadings themselves may not pose imminent danger so it is ranked as a relatively low priority. However, like BOD, TSS is an indicator of threat to the aquatic system, and in high concentrations can lead to massive dead zones, where no fish or plant life can survive for long. If the water source is used for higher purposes that serve the food chain, the impacts of high TSS loadings can be severe.

\section{Chemicals and metals to water}

Contamination of drinking water supplies from industrial waste is a result of various types of industrial processes and disposal practices. Industries that use large amounts of water for processing have the potential to pollute waterways through the discharge of their waste into streams and rivers, or by run-off and seepage of stored wastes into nearby water sources. Other disposal practices which cause water contamination include improper disposal of wastes in surface impoundments. This latter form of pollution is defined as land pollution in the next section.

Industrial chemical waste consists of both organic and inorganic substances. Organic wastes include pesticide residues, solvents and cleaning fluids, dissolved residue from fruit and vegetables, and lignin from pulp and paper to name a few. Effluents can also contain inorganic wastes such as brine salts and metals. Most chemicals are discharged directly into waterways as waste. Many enter the water after everyday use in the home, agriculture and industry. They constantly change the chemical composition of our waters. One way is seepage: chemicals soak through the earth into groundwater from waste disposal sites and agricultural land, for example. Another way is runoff: chemicals are washed into bodies of water from the land where they were used or spilled, or from the air into which they were emitted. Chemicals can cause problems with the taste, odor and color in water. Metals may not be detectable, but can be harmful in high concentrations. Fish and wildlife can experience reduced fertility, generic deformities, immune system damage, increased incidence of tumors, and even death. Many of the chemicals, such as pesticides, PCBs, and PCPs (polychlorinated phenols), and metals that enter the water are, even in minute amounts, toxic to human, plant and animal life. It is estimated that over 16,000 tons of chemicals and 200 tons of metals were generated as manufacturing waste into water in 2004. These pollution loads are quite small when compared to BOD and TSS loads, however the relative toxicity and 
hazards that these substances pose make them a high priority for authorities to address.

\section{Land pollution}

Land pollution in the context of this study is defined according the USEPA Toxics Release Inventory (TRI). Land pollution is defined as all chemicals, metals, and solid waste disposed of on land within the boundaries of the manufacturing facility, and can include any of the following types of on-site disposal:

- Wastes which are buried on-site in landfills;

- Wastes which are applied or incorporated into soil;

- Surface impoundments as uncovered holding ponds used to volatilize (evaporate wastes into the surrounding atmosphere) or settle waste materials;

- Other forms of land disposal, including accidental spills or leaks; and

- Underground injection of fluids into a subsurface well for the purpose of waste disposal.

Of the three media, land is perhaps the most potentially complex with interactions between soils, the air and underground water exchange. For example one of the metals in the IPPS database is cadmium. Cadmium is produced as an inevitable by-product of zinc (or occasionally lead) refining, since these metals occur together naturally within the raw ore. However, once collected the cadmium is relatively easy to recycle. The most significant use of cadmium is in nickel/ cadmium batteries, as rechargeable or secondary power sources exhibiting high output, long life, low maintenance and high tolerance to physical and electrical stress. Cadmium coatings provide good corrosion resistance, particularly in high stress environments such as marine and aerospace applications where high safety or reliability is required. Other uses of cadmium are as pigments, stabilisers for PVC, in alloys and electronic compounds. Cadmium is also present as an impurity in several products, including phosphate fertilisers, detergents and refined petroleum products.
Another metal commonly used in industrial processes is chromium. The greatest use of chromium is in metal alloys such as stainless steel, protective coatings on metal, magnetic tapes and pigments for paints, cement, paper, rubber, composition floor covering and other materials. Its soluble forms are also used in wood preservatives. Low-level exposure to chromium can irritate the skin and cause ulceration. Long-term exposure can cause kidney and liver damage, and damage to circulatory and nerve tissue. ${ }^{7}$ Chromium often accumulates in aquatic life, adding to the danger of eating fish that may have been exposed to high levels of chromium. Exposure to cadmium can also occur through the consumption of cereals and vegetables grown on soils contaminated by industrial activities and the use of phosphorus fertilizers in agriculture.

The IPPS estimated over 152,000 tons of chemicals and nearly 24,000 tons of metals were generated as waste byproducts to land from manufacturing in 2004. Chemicals represented 86.5 percent of the total load whereas metals constituted 13.5 percent. In terms of load ranking, chemicals are a clear priority in absolute terms and by hazard class both chemicals and metals to land are a high priority because of the potential health implications.

\section{Table B.3. National estimates of land pollution load and evaluation criteria}

\begin{tabular}{|lcccc|}
\hline & $\begin{array}{c}\text { Load } \\
\text { (tons/ } \\
\text { Pear) }\end{array}$ & $\%$ & & $\begin{array}{c}\text { Hazard } \\
\text { rank }\end{array}$ \\
\hline Chemicals to land & 152,438 & 86.48 & 1 & 1 \\
\hline Metals to land & 23,833 & 13.52 & 2 & 1 \\
\hline
\end{tabular}

Hazard ranking indexed as: 1 = high priority, 2 = medium priority, $3=$ low priority.

7. WHO. 1997. Health and Environment in Sustainable Development. WHO, Geneva. 


\section{Toxic Pollution}

The final section in this chapter describes the pollutants categorized in terms of their relative toxicity and hazard. As explained in Chapter 3, the terms toxicity and hazard are sometimes interchangeable, however for the purposes of this study they have very different meanings. Toxicity is determined by the nature of a substance - its chemical and physical properties. Some substances are more toxic than others. The relative hazard of a substance is dependent on its toxicity, the dose received and the length of time exposed.

In the proceeding chapters on sectors and geographical areas, air pollution loads ${ }^{8}$ are weighted by their relative toxicity and compared to their un-weighted loads to see if sector or area priorities change. Where there is a significant difference in ranking, priorities are sensitive to the method used weighted or un-weighted pollution load. This comparative analysis is important for ranking sectors and areas with respect to overall toxicity. Toxicity-weighted loads are not presented in this chapter because the potential differences in ranking are more amenable to sector and area comparisons, not total national loads. However, ranking chemicals and metals by their associated hazard category does remain of interest at this point. Once again, the concept of hazard adopted in this study is purely categorical in nature. The ranking procedure begins with categorizing chemical and metal loads into high, medium and low hazard categories according to their associated $L_{50}$ and $L_{50}$ values. These chemical and metal loads are then summarized at the national level and are presented here.

Several priority substances are of special note because of their known toxicity and some because the sheer magnitude of their use warrants further attention. ${ }^{9}$ Over 513,000 tons of toluene (a developmental toxicant) and 34,000 tons of carbon disulfide (a developmental and reproductive toxicant) are estimated to have been released. Occupational exposure to toluene can occur in all phases of the manufacture and use of toluene di-isocyanate because of its volatility. The highest levels of exposure occur during spraying with polyurethane foam, in a procedure that is usually conducted in confined spaces. Lacquer-spray workers and their assistants are exposed when using isocyanate lacquers (containing 0.2 percent to 1 percent monomeric toluene diisocyanate, also found in the footwear industry in Vietnam). The jobs in which exposure may occur are: adhesive production, application of insulation and production of toluene di-isocyanate resins and lacquers, organic chemical synthesis, paint spraying, polyurethane foam production, work with rubber, shipbuilding, textile processing and wirecoating (WHO, 1987).

More than 298,000 tons of methanol (a suspected neurological toxicant) are estimated to have been released to air and water and more than 62,000 tons of hydrochloric acid (a suspected respiratory toxicant) was released to the nation's air, land and water from manufacturing. Over 11,000 tons of asbestos, a cancer-causing toxic, are estimated to have been released to the environment, mostly to land.

171 tons of dioxins (dibenzofuran) are estimated to have been released to air, land and water. In addition to cancer, exposure to dioxins can cause severe reproductive and developmental problems (at levels 100 times lower than those associated with its cancer-causing effects). Dioxins are well-known for their ability to damage the immune system and interfere with hormonal systems. Dioxin exposure has been linked to birth defects, inability to maintain pregnancy, decreased fertility, reduced sperm counts, endometriosis, diabetes, learning disabilities, immune system suppression, lung problems, skin disorders and lowered testosterone levels. The major source of dioxin in the environment comes from waste-burning incinerators of various sorts and from general burning of wastes. Dioxin pollution is also associated with paper mills which use chlorine bleaching in their process and with the production of Polyvinyl Chloride (PVC) plastics and with the production of certain chlorinated chemicals (like many pesticides).

8. Only air pollution loads are toxicity-weighted since the Threshold Limit Values (TLVs) used to weight pollution loads are based on air inhalation indexes (see Annex 4 for details).

9. See the website of the Toxics Release Inventory Program (TRI) for more details on each substance (www.epa.gov/tri). 
Among metals, zinc and copper (fume or dust) were generated in significant loads from manufacturing as were chromium (6,000 tons), lead (14,000 tons) and mercury (286 tons). Other notable toxics were arsenic (536 tons), asbestos (11,000 tons) and PCBs (582 tons). 


\section{ANMEX B. DETAlLED POLLUTION ESTIMATES FOR PRIORITY SECTORS}

Table B.1. National: Individual ranking of conventional pollution load to air, land and water by sector

\begin{tabular}{|c|c|c|c|c|c|}
\hline Sector (VSIC-4) & $\mathrm{SO}_{2}$ & $\mathrm{NO}_{2}$ & VOC & PM-10 & TSP \\
\hline Fertilizers and nitrogen compounds & 9 & 8 & 6 & 23 & 21 \\
\hline Footwear & 11 & 16 & 3 & 7 & 5 \\
\hline Basic iron and steel & 7 & 12 & 19 & 6 & 14 \\
\hline Basic chemicals, except fertilizers and nitrogen compounds & 14 & 14 & 11 & 30 & 27 \\
\hline Processing and preserving of fish and fish products & 2 & 3 & 1 & 2 & 2 \\
\hline Plastics products & 10 & 4 & 2 & 52 & 23 \\
\hline Pulp, paper and paperboard & 4 & 6 & 14 & 13 & 13 \\
\hline Casting of non-ferrous metals & 6 & 46 & 47 & 36 & 25 \\
\hline Other chemical products n.e.c. & 27 & 23 & 24 & 29 & 36 \\
\hline Forging, pressing, stamping and roll-forming of metal; powder metallurgy & 20 & 35 & 52 & 22 & 34 \\
\hline Other rubber products & 22 & 10 & 7 & 51 & 37 \\
\hline Corrugated paper and paperboard, containers of paper and paperboard & 3 & 5 & 12 & 11 & 10 \\
\hline Preparation and spinning of textile fibres; weaving of textiles & 15 & 7 & 20 & 34 & 26 \\
\hline Veneer sheets; plywood, laminboard, particle board, other panels and boards & 5 & 9 & 16 & 15 & 11 \\
\hline Casting of iron and steel & 23 & 25 & 51 & 14 & 31 \\
\hline Treatment and coating of metals; general mechanical engineering & 24 & 45 & 63 & 26 & 38 \\
\hline Structural non-refractory clay and ceramic products & 17 & 2 & 8 & 3 & 3 \\
\hline Other manufacturing n.e.c. & 16 & 18 & 15 & 19 & 16 \\
\hline Pesticides and other agro-chemical products & 51 & 42 & 45 & 44 & 50 \\
\hline Furniture & 52 & 53 & 4 & 31 & 32 \\
\hline Other fabricated metal products n.e.c. & 59 & 49 & 28 & 69 & 60 \\
\hline Cement, lime and plaster & 1 & 1 & 29 & 1 & 1 \\
\hline Pharmaceuticals, medicinal chemicals and botanical products & 34 & 38 & 34 & 55 & 43 \\
\hline Vegetable and animal oils and fats & 8 & 17 & 13 & 4 & 4 \\
\hline Soap and detergents, cleaning and polishing preparations, perfumes and toilet pr & 29 & 32 & 26 & 20 & 28 \\
\hline Other electrical equipment n.e.c. & 42 & 31 & 40 & 32 & 33 \\
\hline
\end{tabular}




\begin{tabular}{|c|c|c|c|c|c|c|c|c|c|c|c|}
\hline $\begin{array}{c}\text { Toxic } \\
\text { Metals } \\
\text { Air }\end{array}$ & $\begin{array}{l}\text { Toxic } \\
\text { Metals } \\
\text { Land }\end{array}$ & $\begin{array}{l}\text { Toxic } \\
\text { Metals } \\
\text { Water }\end{array}$ & $\begin{array}{c}\text { Toxic } \\
\text { Air }\end{array}$ & $\begin{array}{l}\text { Toxic } \\
\text { Land }\end{array}$ & $\begin{array}{c}\text { Toxic } \\
\text { Water }\end{array}$ & BOD & TSS & Air & Land & Water & Index \\
\hline 7 & 4 & 1 & 3 & 1 & 1 & 7 & 8 & 11 & 3 & 4 & 6 \\
\hline 3 & 3 & 5 & 1 & 5 & 22 & 6 & 11 & 7 & 4 & 11 & 7 \\
\hline 1 & 1 & 2 & 16 & 6 & 10 & 40 & 1 & 11 & 4 & 13 & 9 \\
\hline 10 & 11 & 3 & 6 & 3 & 2 & 9 & 21 & 16 & 7 & 9 & 11 \\
\hline 48 & 12 & 40 & 12 & 2 & 7 & 5 & 15 & 10 & 7 & 17 & 11 \\
\hline 26 & 9 & 4 & 2 & 4 & 4 & 14 & 27 & 17 & 7 & 12 & 12 \\
\hline 19 & 44 & 8 & 8 & 15 & 5 & 2 & 4 & 11 & 30 & 5 & 15 \\
\hline 2 & 2 & 18 & 20 & 8 & 23 & 12 & 7 & 26 & 5 & 15 & 15 \\
\hline 25 & 18 & 7 & 15 & 7 & 8 & 16 & 29 & 26 & 13 & 15 & 18 \\
\hline 5 & 5 & 13 & 30 & 16 & 25 & 17 & 6 & 28 & 11 & 15 & 18 \\
\hline 35 & 15 & 12 & 5 & 9 & 11 & 25 & 31 & 24 & 12 & 20 & 19 \\
\hline 78 & 64 & 6 & 7 & 13 & 3 & 1 & 2 & 18 & 39 & 3 & 20 \\
\hline 16 & 20 & 29 & 22 & 23 & 9 & 18 & 33 & 20 & 22 & 22 & 21 \\
\hline 62 & 60 & 10 & 11 & 20 & 6 & 3 & 5 & 18 & 40 & 6 & 21 \\
\hline 6 & 7 & 9 & 60 & 19 & 17 & 64 & 3 & 30 & 13 & 23 & 22 \\
\hline 9 & 8 & 17 & 43 & 24 & 30 & 20 & 10 & 35 & 16 & 19 & 24 \\
\hline 8 & 6 & 14 & 13 & 22 & 59 & 77 & 65 & 8 & 14 & 54 & 25 \\
\hline 29 & 28 & 23 & 14 & 28 & 36 & 30 & 47 & 18 & 28 & 34 & 27 \\
\hline 43 & 21 & 34 & 19 & 11 & 18 & 39 & 20 & 42 & 16 & 28 & 29 \\
\hline 27 & 35 & 16 & 4 & 12 & 44 & 13 & 63 & 29 & 24 & 34 & 29 \\
\hline 13 & 17 & 22 & 23 & 31 & 28 & 45 & 16 & 43 & 24 & 28 & 32 \\
\hline 32 & 23 & 97 & 74 & 45 & 12 & 59 & 12 & 20 & 34 & 45 & 33 \\
\hline 80 & 48 & 54 & 17 & 10 & 21 & 33 & 9 & 43 & 29 & 29 & 34 \\
\hline 89 & 56 & 85 & 53 & 18 & 16 & 19 & 35 & 27 & 37 & 39 & 34 \\
\hline 66 & 57 & 19 & 21 & 25 & 29 & 28 & 45 & 32 & 41 & 30 & 34 \\
\hline 24 & 25 & 31 & 32 & 34 & 50 & 51 & 48 & 33 & 30 & 45 & 36 \\
\hline
\end{tabular}




\begin{tabular}{|c|c|c|c|c|c|}
\hline Sector (VSIC-4) & $\mathrm{SO}_{2}$ & $\mathrm{NO}_{2}$ & voc & PM-10 & TSP \\
\hline Recycling of metal waste and scrap & 37 & 59 & 89 & 37 & 49 \\
\hline Basic precious and non-ferrous metals & 31 & 69 & 81 & 38 & 42 \\
\hline Wearing apparel, except fur apparel & 54 & 66 & 18 & 77 & 67 \\
\hline Other non-metallic mineral products n.e.c. & 18 & 20 & 33 & 24 & 19 \\
\hline Production, processing and preserving of meat and meat products & 13 & 21 & 22 & 5 & 6 \\
\hline Refined petroleum products & 21 & 22 & 23 & 39 & 35 \\
\hline Articles of concrete, cement and plaster & 25 & 26 & 57 & 8 & 8 \\
\hline Other textiles n.e.c. & 46 & 33 & 17 & 53 & 44 \\
\hline Motorcycles & 53 & 56 & 5 & 114 & 46 \\
\hline Building and repairing of ships & 62 & 55 & 49 & 41 & 70 \\
\hline Paints, varnishes and similar coatings, printing ink and mastics & 43 & 52 & 30 & 28 & 40 \\
\hline Railway and tramway locomotives and rolling stock & 45 & 51 & 76 & 33 & 48 \\
\hline Tanning and dressing of leather & 72 & 88 & 55 & 68 & 85 \\
\hline Structural metal products & 69 & 40 & 38 & 57 & 71 \\
\hline Refractory ceramic products & 35 & 13 & 48 & 10 & 7 \\
\hline Malt liquors and malt & 19 & 15 & 50 & 59 & 41 \\
\hline Sugar & 12 & 11 & 27 & 35 & 9 \\
\hline Non-structural non-refractory ceramic ware & 64 & 72 & 36 & 114 & 47 \\
\hline Other food products n.e.c. & 33 & 19 & 61 & 43 & 39 \\
\hline Tanks, reservoirs and containers of metal & 85 & 65 & 59 & 71 & 75 \\
\hline Other products of wood; cork, straw and plaiting materials & 39 & 36 & 10 & 17 & 20 \\
\hline Parts and accessories for motor vehicles and their engines & 65 & 73 & 32 & 56 & 56 \\
\hline Insulated wire and cable & 63 & 50 & 69 & 64 & 51 \\
\hline Plastics in primary forms and of synthetic rubber & 55 & 34 & 41 & 92 & 69 \\
\hline Starches and starch products & 28 & 28 & 35 & 9 & 15 \\
\hline Electric motors, generators and transformers & 47 & 57 & 65 & 78 & 82 \\
\hline Processing and preserving of fruit and vegetables & 44 & 39 & 54 & 21 & 24 \\
\hline
\end{tabular}




\begin{tabular}{|c|c|c|c|c|c|c|c|c|c|c|c|}
\hline $\begin{array}{c}\text { Toxic } \\
\text { Metals } \\
\text { Air }\end{array}$ & $\begin{array}{c}\text { Toxic } \\
\text { Metals } \\
\text { Land }\end{array}$ & $\begin{array}{l}\text { Toxic } \\
\text { Metals } \\
\text { Water }\end{array}$ & $\begin{array}{c}\text { Toxic } \\
\text { Air }\end{array}$ & $\begin{array}{l}\text { Toxic } \\
\text { Land }\end{array}$ & $\begin{array}{l}\text { Toxic } \\
\text { Water }\end{array}$ & BOD & TSS & Air & Land & Water & Index \\
\hline 14 & 14 & 27 & 75 & 39 & 49 & 27 & 18 & 51 & 27 & 30 & 36 \\
\hline 11 & 13 & 44 & 62 & 36 & 53 & 23 & 26 & 48 & 25 & 37 & 36 \\
\hline 4 & 10 & 15 & 9 & 14 & 31 & 85 & 88 & 42 & 12 & & 36 \\
\hline 70 & 77 & 25 & 29 & 52 & 14 & 11 & 17 & 30 & 65 & 17 & 37 \\
\hline 97 & 66 & 56 & 68 & 26 & 26 & 22 & 40 & 33 & 46 & 36 & 38 \\
\hline 51 & 69 & 30 & 63 & 27 & 45 & 35 & 38 & 36 & 48 & 37 & 40 \\
\hline 21 & 40 & 71 & 33 & 29 & 74 & 43 & 59 & 25 & 35 & 62 & 41 \\
\hline 53 & 53 & 53 & 10 & 30 & 24 & 42 & 57 & 37 & 42 & 44 & 41 \\
\hline 17 & 38 & 11 & 35 & 47 & 13 & 54 & 56 & 47 & 43 & 34 & 41 \\
\hline 15 & 31 & 38 & 25 & 41 & 42 & 67 & 32 & 45 & 36 & 45 & 42 \\
\hline 31 & 49 & 28 & 26 & 21 & 46 & 66 & 87 & 36 & 35 & 57 & 42 \\
\hline 18 & 22 & 24 & 86 & 53 & 43 & 86 & 13 & 51 & 38 & 42 & 43 \\
\hline 86 & 29 & 55 & 31 & 17 & 33 & 31 & 43 & 69 & 23 & 41 & 44 \\
\hline 22 & 27 & 20 & 46 & 40 & 15 & 75 & 97 & 49 & 34 & 52 & 45 \\
\hline 28 & 32 & 49 & 47 & 51 & 89 & 56 & 73 & 27 & 42 & 67 & 45 \\
\hline 82 & 33 & 80 & 42 & 60 & 38 & 26 & 39 & 44 & 47 & 46 & 45 \\
\hline 108 & 98 & 42 & 73 & 38 & 56 & 8 & 24 & 39 & 68 & 33 & 47 \\
\hline 44 & 19 & 37 & 44 & 33 & 95 & 38 & 50 & 60 & 26 & 55 & 47 \\
\hline 104 & 99 & 21 & 57 & 37 & 27 & 15 & 28 & 51 & 68 & 23 & 47 \\
\hline 41 & 30 & 26 & 50 & 44 & 40 & 58 & 42 & 64 & 37 & 42 & 47 \\
\hline 71 & 97 & 114 & 18 & 32 & 20 & 44 & 60 & 30 & 65 & 60 & 51 \\
\hline 50 & 50 & 46 & 24 & 46 & 68 & 24 & 86 & 51 & 48 & 56 & 52 \\
\hline 23 & 16 & 48 & 56 & 35 & 54 & 101 & 101 & 54 & 26 & 76 & 52 \\
\hline 87 & 63 & 41 & 38 & 42 & 32 & 47 & 55 & 59 & 53 & 44 & 52 \\
\hline 101 & 83 & 72 & 89 & 43 & 41 & 34 & 53 & 44 & 63 & 50 & 52 \\
\hline 38 & 43 & 35 & 40 & 50 & 65 & 48 & 67 & 58 & 47 & 54 & 53 \\
\hline 90 & 91 & 36 & 81 & 57 & 48 & 21 & 36 & 50 & 74 & 35 & 53 \\
\hline
\end{tabular}




\begin{tabular}{|c|c|c|c|c|c|}
\hline Sector (VSIC-4) & $\mathrm{SO}_{2}$ & $\mathrm{NO}_{2}$ & Voc & PM-10 & TSP \\
\hline Domestic appliances n.e.c. & 81 & 71 & 62 & 73 & 80 \\
\hline Agricultural and forestry machinery & 56 & 60 & 60 & 86 & 64 \\
\hline Glass and glass products & 41 & 27 & 67 & 27 & 29 \\
\hline Finishing of textiles & 49 & 30 & 64 & 49 & 52 \\
\hline Rubber tyres and tubes; retreading and rebuilding of rubber tyres & 30 & 37 & 21 & 42 & 45 \\
\hline Cutting, shaping and finishing of stone & 40 & 44 & 78 & 16 & 18 \\
\hline Electronic valves and tubes and other electronic components & 50 & 62 & 70 & 81 & 88 \\
\hline Games and toys & 80 & 91 & 66 & 61 & 83 \\
\hline Other articles of paper and paperboard & 74 & 54 & 58 & 75 & 89 \\
\hline Sawmilling and planing of wood & 48 & 29 & 25 & 25 & 22 \\
\hline Accumulators, primary cells and primary batteries & 96 & 81 & 90 & 76 & 78 \\
\hline Luggage, handbags, saddlery and harness & 104 & 97 & 53 & 114 & 92 \\
\hline Television and radio receivers, sound, video recording, reproducing apparatus, etc. & 97 & 102 & 74 & 80 & 108 \\
\hline Electric lamps and lighting equipment & 98 & 80 & 71 & 83 & 77 \\
\hline Motor vehicles & 60 & 68 & 31 & 58 & 55 \\
\hline Engines and turbines, except aircraft, vehicle and cycle engines & 75 & 75 & 72 & 48 & 74 \\
\hline Printing & 100 & 95 & 44 & 97 & 96 \\
\hline Cutlery, hand tools and general hardware & 89 & 58 & 75 & 114 & 93 \\
\hline Builders' carpentry and joinery & 57 & 43 & 42 & 47 & 30 \\
\hline Other transport equipment n.e.c. & 73 & 82 & 73 & 85 & 90 \\
\hline Other special purpose machinery & 88 & 87 & 86 & 91 & 94 \\
\hline Bicycles and invalid carriages & 83 & 90 & 37 & 74 & 73 \\
\hline Grain mill products & 36 & 41 & 56 & 12 & 12 \\
\hline Dairy products & 77 & 64 & 117 & 89 & 65 \\
\hline Prepared animal feeds & 32 & 48 & 100 & 18 & 17 \\
\hline Electricity distribution and control apparatus & 71 & 76 & 98 & 84 & 84 \\
\hline Distilling, rectifying and blending of spirits; ethyl alcohol production & 38 & 47 & 9 & 40 & 54 \\
\hline
\end{tabular}




\begin{tabular}{|c|c|c|c|c|c|c|c|c|c|c|c|}
\hline $\begin{array}{c}\text { Toxic } \\
\text { Metals } \\
\text { Air }\end{array}$ & $\begin{array}{l}\text { Toxic } \\
\text { Metals } \\
\text { Land }\end{array}$ & $\begin{array}{l}\text { Toxic } \\
\text { Metals } \\
\text { Water }\end{array}$ & $\begin{array}{c}\text { Toxic } \\
\text { Air }\end{array}$ & $\begin{array}{l}\text { Toxic } \\
\text { Land }\end{array}$ & $\begin{array}{l}\text { Toxic } \\
\text { Water }\end{array}$ & BOD & TSS & Air & Land & Water & Index \\
\hline 46 & 37 & 32 & 58 & 56 & 47 & 61 & 46 & 67 & 47 & 47 & 53 \\
\hline 45 & 39 & 39 & 59 & 59 & 55 & 65 & 51 & 61 & 49 & 53 & 54 \\
\hline 30 & 65 & 77 & 70 & 67 & 34 & 49 & 66 & 42 & 66 & 57 & 55 \\
\hline 60 & 61 & 67 & 72 & 73 & 19 & 36 & 54 & 54 & 67 & 44 & 55 \\
\hline 34 & 24 & 51 & 79 & 63 & 76 & 116 & 78 & 41 & 44 & 80 & 55 \\
\hline 40 & 59 & 81 & 65 & 48 & 93 & 52 & 71 & 43 & 54 & 74 & 57 \\
\hline 42 & 46 & 43 & 48 & 55 & 73 & 50 & 69 & 63 & 51 & 59 & 57 \\
\hline 47 & 36 & 58 & 37 & 64 & 66 & 93 & 22 & 66 & 50 & 60 & 59 \\
\hline 39 & 72 & 57 & 28 & 69 & 63 & 29 & 49 & 60 & 71 & 50 & 60 \\
\hline 65 & 75 & 86 & 41 & 85 & 101 & 32 & 34 & 36 & 80 & 63 & 60 \\
\hline 57 & 42 & 61 & 54 & 72 & 88 & 37 & 41 & 76 & 57 & 57 & 63 \\
\hline 12 & 26 & 33 & 36 & 62 & 64 & 110 & 102 & 73 & 44 & 77 & 65 \\
\hline 75 & 52 & 65 & 45 & 49 & 67 & 46 & 64 & 83 & 51 & 61 & 65 \\
\hline 52 & 41 & 50 & 71 & 70 & 69 & 76 & 58 & 76 & 56 & 63 & 65 \\
\hline 49 & 47 & 79 & 39 & 61 & 77 & 100 & 103 & 51 & 54 & 90 & 65 \\
\hline 20 & 58 & 70 & 51 & 74 & 75 & 91 & 83 & 59 & 66 & 80 & 68 \\
\hline 36 & 45 & 60 & 34 & 71 & 78 & 69 & 98 & 72 & 58 & 76 & 69 \\
\hline 37 & 34 & 75 & 64 & 66 & 84 & 114 & 62 & 76 & 50 & 84 & 70 \\
\hline 69 & 80 & 90 & 87 & 101 & 103 & 41 & 44 & 54 & 91 & 70 & 71 \\
\hline 58 & 51 & 69 & 69 & 81 & 58 & 88 & 75 & 76 & 66 & 73 & 71 \\
\hline 68 & 54 & 59 & 83 & 76 & 72 & 74 & 61 & 85 & 65 & 67 & 72 \\
\hline 61 & 73 & 52 & 76 & 84 & 52 & 90 & 96 & 71 & 79 & 73 & 74 \\
\hline 67 & 89 & 114 & 101 & 88 & 71 & 72 & 93 & 46 & 89 & 88 & 74 \\
\hline 103 & 121 & 114 & 108 & 54 & 37 & 4 & 30 & 89 & 88 & 46 & 74 \\
\hline 56 & 101 & 114 & 95 & 80 & 60 & 63 & 85 & 52 & 91 & 81 & 74 \\
\hline 55 & 55 & 63 & 85 & 77 & 92 & 70 & 91 & 79 & 66 & 79 & 75 \\
\hline 121 & 121 & 114 & 125 & 114 & 39 & 10 & 23 & 62 & 118 & 47 & 75 \\
\hline
\end{tabular}




\begin{tabular}{|c|c|c|c|c|c|}
\hline Sector (VSIC-4) & $\mathrm{SO}_{2}$ & $\mathrm{NO}_{2}$ & VOC & PM-10 & TSP \\
\hline Repair of motor vehicles (except maintenance) & 76 & 78 & 46 & 65 & 66 \\
\hline Tobacco products & 26 & 24 & 43 & 46 & 68 \\
\hline Television and radio transmitters; apparatus for line telephony and telegraphy & 105 & 107 & 91 & 88 & 116 \\
\hline Pumps, compressors, taps and valves & 78 & 86 & 80 & 87 & 79 \\
\hline Dressing and dyeing of fur; articles of fur & 86 & 99 & 68 & 90 & 72 \\
\hline Other general purpose machinery & 95 & 93 & 96 & 93 & 100 \\
\hline Machine-tools & 61 & 77 & 84 & 98 & 76 \\
\hline Knitted and crocheted fabrics and articles & 70 & 79 & 103 & 60 & 57 \\
\hline Cocoa, chocolate and sugar confectionery & 67 & 63 & 102 & 67 & 59 \\
\hline Man-made fibres & 87 & 70 & 93 & 95 & 98 \\
\hline Macaroni, noodles, couscous and similar farinaceous products & 68 & 61 & 88 & 66 & 58 \\
\hline Medical and surgical equipment and orthopaedic appliances & 101 & 103 & 79 & 96 & 103 \\
\hline Jewellery and related articles & 84 & 98 & 113 & 114 & 81 \\
\hline Sports goods & 115 & 114 & 82 & 54 & 86 \\
\hline Bodies (coachwork) for motor vehicles; trailers and semi-trailers & 90 & 89 & 83 & 79 & 91 \\
\hline Machinery for mining, quarrying and construction & 82 & 85 & 97 & 94 & 95 \\
\hline Lifting and handling equipment & 79 & 84 & 95 & 70 & 87 \\
\hline Building and repairing of pleasure and sporting boats & 110 & 112 & 106 & 62 & 109 \\
\hline Made-up textile articles, except apparel & 91 & 94 & 39 & 50 & 61 \\
\hline Carpets and rugs & 126 & 126 & 126 & 114 & 126 \\
\hline Repairing of ship, boats & 99 & 104 & 87 & 45 & 97 \\
\hline Machinery for textile, apparel and leather production & 92 & 96 & 105 & 101 & 102 \\
\hline Bearings, gears, gearing and driving elements & 94 & 105 & 104 & 100 & 105 \\
\hline Wooden containers & 103 & 83 & 101 & 72 & 63 \\
\hline Ovens, furnaces and furnace burners & 109 & 108 & 114 & 103 & 113 \\
\hline Watches and clocks & 107 & 113 & 120 & 114 & 104 \\
\hline Machinery for food, beverage and tobacco processing & 93 & 92 & 111 & 102 & 101 \\
\hline
\end{tabular}




\begin{tabular}{|c|c|c|c|c|c|c|c|c|c|c|c|}
\hline $\begin{array}{c}\text { Toxic } \\
\text { Metals } \\
\text { Air }\end{array}$ & $\begin{array}{c}\text { Toxic } \\
\text { Metals } \\
\text { Land }\end{array}$ & $\begin{array}{l}\text { Toxic } \\
\text { Metals } \\
\text { Water }\end{array}$ & $\begin{array}{c}\text { Toxic } \\
\text { Air }\end{array}$ & $\begin{array}{l}\text { Toxic } \\
\text { Land }\end{array}$ & $\begin{array}{l}\text { Toxic } \\
\text { Water }\end{array}$ & BOD & TSS & Air & Land & Water & Index \\
\hline 63 & 62 & 84 & 61 & 75 & 87 & 105 & 106 & 65 & 69 & 96 & 76 \\
\hline 121 & 121 & 114 & 27 & 78 & 57 & 62 & 84 & 51 & 100 & 79 & 76 \\
\hline 85 & 67 & 78 & 67 & 68 & 81 & 53 & 74 & 94 & 68 & 72 & 78 \\
\hline 77 & 71 & 66 & 91 & 87 & 83 & 83 & 70 & 83 & 79 & 76 & 79 \\
\hline 96 & 74 & 92 & 52 & 79 & 100 & 60 & 72 & 80 & 77 & 81 & 79 \\
\hline 76 & 68 & 62 & 90 & 83 & 80 & 82 & 68 & 92 & 76 & 73 & 80 \\
\hline 72 & 70 & 74 & 98 & 91 & 86 & 94 & 81 & 81 & 81 & 84 & 82 \\
\hline 121 & 103 & 114 & 77 & 58 & 51 & 78 & 94 & 81 & 81 & 84 & 82 \\
\hline 110 & 112 & 47 & 106 & 86 & 82 & 55 & 90 & 82 & 99 & 69 & 83 \\
\hline 102 & 94 & 76 & 96 & 90 & 62 & 71 & 80 & 92 & 92 & 72 & 85 \\
\hline 109 & 110 & 45 & 111 & 89 & 79 & 81 & 108 & 80 & 100 & 78 & 86 \\
\hline 84 & 78 & 88 & 78 & 82 & 94 & 73 & 89 & 92 & 80 & 86 & 86 \\
\hline 92 & 88 & 64 & 99 & 104 & 61 & 122 & 14 & 97 & 96 & 65 & 86 \\
\hline 93 & 86 & 68 & 80 & 95 & 107 & 122 & 19 & 89 & 91 & 79 & 86 \\
\hline 74 & 79 & 73 & 94 & 94 & 70 & 108 & 100 & 86 & 87 & 88 & 87 \\
\hline 81 & 76 & 87 & 100 & 92 & 85 & 84 & 92 & 91 & 84 & 87 & 87 \\
\hline 64 & 85 & 95 & 93 & 100 & 99 & 102 & 104 & 82 & 93 & 100 & 91 \\
\hline 59 & 81 & 96 & 84 & 99 & 113 & 115 & 52 & 92 & 90 & 94 & 92 \\
\hline 73 & 100 & 114 & 55 & 96 & 96 & 121 & 125 & 66 & 98 & 114 & 93 \\
\hline 121 & 121 & 114 & 82 & 65 & 35 & 57 & 77 & 117 & 93 & 71 & 94 \\
\hline 33 & 92 & 94 & 66 & 97 & 112 & 117 & 122 & 76 & 95 & 111 & 94 \\
\hline 79 & 84 & 89 & 103 & 98 & 98 & 95 & 99 & 97 & 91 & 95 & 94 \\
\hline 83 & 82 & 91 & 104 & 106 & 91 & 106 & 95 & 99 & 94 & 96 & 96 \\
\hline 98 & 106 & 105 & 118 & 120 & 111 & 68 & 76 & 91 & 113 & 90 & 98 \\
\hline 91 & 87 & 82 & 112 & 107 & 102 & 98 & 82 & 107 & 97 & 91 & 98 \\
\hline 94 & 108 & 93 & 105 & 105 & 97 & 122 & 25 & 108 & 107 & 84 & 100 \\
\hline 95 & 93 & 102 & 115 & 103 & 104 & 89 & 110 & 101 & 98 & 101 & 100 \\
\hline
\end{tabular}




\begin{tabular}{|c|c|c|c|c|c|}
\hline Sector (VSIC-4) & $\mathrm{SO}_{2}$ & $\mathrm{NO}_{2}$ & VOC & PM-10 & TSP \\
\hline Steam generators, except central heating hot water boilers & 106 & 101 & 115 & 99 & 110 \\
\hline Coke oven products & 66 & 67 & 107 & 63 & 62 \\
\hline Musical instruments & 119 & 109 & 112 & 82 & 112 \\
\hline Recycling of non-metal waste and scrap & 113 & 119 & 109 & 105 & 114 \\
\hline Cordage, rope, twine and netting & 58 & 74 & 77 & 114 & 53 \\
\hline Optical instruments and photographic equipment & 111 & 106 & 116 & 114 & 106 \\
\hline Office, accounting and computing machinery & 116 & 118 & 108 & 114 & 118 \\
\hline Publishing of newspapers, journals and periodicals & 112 & 110 & 85 & 104 & 111 \\
\hline Industrial process control equipment & 118 & 117 & 121 & 114 & 120 \\
\hline Publishing of books, brochures, musical books and other publications & 114 & 115 & 94 & 106 & 115 \\
\hline Instruments and appliances for measuring, checking, testing, navigating, etc. & 121 & 121 & 119 & 110 & 121 \\
\hline Reproduction of recorded media & 122 & 122 & 118 & 108 & 123 \\
\hline Wines & 102 & 111 & 125 & 114 & 107 \\
\hline Service activities related to printing & 117 & 116 & 99 & 107 & 117 \\
\hline Bakery products & 108 & 100 & 92 & 114 & 99 \\
\hline Publishing of recorded media & 125 & 125 & 122 & 111 & 124 \\
\hline Other publishing & 120 & 120 & 110 & 109 & 119 \\
\hline Machinery for metallurgy & 123 & 123 & 124 & 113 & 122 \\
\hline Aircraft and spacecraft & 124 & 124 & 123 & 112 & 125 \\
\hline Processing of nuclear fuel & 126 & 126 & 126 & 114 & 126 \\
\hline Soft drinks; production of mineral waters & 126 & 126 & 126 & 114 & 126 \\
\hline Weapons and ammunition & 126 & 126 & 126 & 114 & 126 \\
\hline
\end{tabular}

Note: Rankings are sorted in ascending order of the column labeled 'Index'. The first quartile has no colored box (white/light green) = high pollution load The second quartile is colored dark blue. The third quartile is medium blue.

The fourth quartile is light blue = low pollution load. 


\begin{tabular}{|c|c|c|c|c|c|c|c|c|c|c|c|}
\hline $\begin{array}{c}\text { Toxic } \\
\text { Metals } \\
\text { Air }\end{array}$ & $\begin{array}{l}\text { Toxic } \\
\text { Metals } \\
\text { Land }\end{array}$ & $\begin{array}{l}\text { Toxic } \\
\text { Metals } \\
\text { Water }\end{array}$ & $\begin{array}{c}\text { Toxic } \\
\text { Air }\end{array}$ & $\begin{array}{l}\text { Toxic } \\
\text { Land }\end{array}$ & $\begin{array}{l}\text { Toxic } \\
\text { Water }\end{array}$ & BOD & TSS & Air & Land & Water & Index \\
\hline 88 & 96 & 83 & 116 & 109 & 90 & 103 & 116 & 105 & 103 & 98 & 102 \\
\hline 111 & 111 & 101 & 120 & 123 & 105 & 99 & 112 & 85 & 117 & 104 & 102 \\
\hline 100 & 107 & 100 & 114 & 113 & 117 & 122 & 37 & 107 & 110 & 94 & 104 \\
\hline 105 & 105 & 99 & 109 & 112 & 114 & 80 & 79 & 111 & 109 & 93 & 104 \\
\hline 54 & 121 & 114 & 49 & 124 & 124 & 122 & 126 & 68 & 123 & 122 & 104 \\
\hline 113 & 90 & 114 & 88 & 93 & 116 & 113 & 123 & 108 & 92 & 117 & 105 \\
\hline 99 & 95 & 98 & 97 & 102 & 109 & 120 & 113 & 110 & 99 & 110 & 106 \\
\hline 114 & 113 & 108 & 92 & 111 & 119 & 87 & 111 & 104 & 112 & 106 & 107 \\
\hline 106 & 102 & 103 & 110 & 108 & 106 & 112 & 120 & 115 & 105 & 110 & 110 \\
\hline 115 & 115 & 110 & 102 & 115 & 121 & 92 & 114 & 109 & 115 & 109 & 111 \\
\hline 107 & 104 & 106 & 119 & 117 & 110 & 104 & 107 & 117 & 111 & 107 & 111 \\
\hline 112 & 109 & 104 & 117 & 116 & 108 & 96 & 109 & 117 & 113 & 104 & 111 \\
\hline 121 & 120 & 114 & 121 & 110 & 124 & 79 & 105 & 114 & 115 & 106 & 112 \\
\hline 118 & 117 & 111 & 107 & 118 & 122 & 97 & 115 & 112 & 118 & 111 & 113 \\
\hline 121 & 121 & 114 & 122 & 119 & 124 & 111 & 118 & 108 & 120 & 117 & 115 \\
\hline 117 & 114 & 107 & 123 & 122 & 115 & 109 & 117 & 121 & 118 & 112 & 117 \\
\hline 120 & 119 & 112 & 113 & 121 & 123 & 107 & 121 & 116 & 120 & 116 & 117 \\
\hline 116 & 116 & 113 & 126 & 126 & 118 & 118 & 119 & 121 & 121 & 117 & 120 \\
\hline 119 & 118 & 109 & 124 & 125 & 120 & 119 & 124 & 122 & 122 & 118 & 120 \\
\hline 121 & 121 & 114 & 127 & 127 & 124 & 122 & 126 & 124 & 124 & 122 & 123 \\
\hline 121 & 121 & 114 & 127 & 127 & 124 & 122 & 126 & 124 & 124 & 122 & 123 \\
\hline 121 & 121 & 114 & 127 & 127 & 124 & 122 & 126 & 124 & 124 & 122 & 123 \\
\hline
\end{tabular}


Table B.2.National: Summary of Top Sectors by Medium

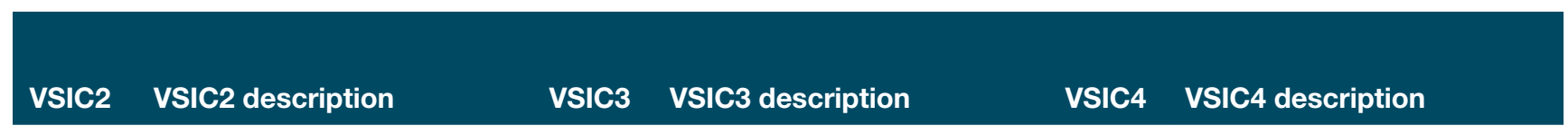

\begin{tabular}{|c|c|c|c|c|c|}
\hline & AIR & & & & \\
\hline \multirow[t]{3}{*}{ D15 } & Food products and beverages & D151 & $\begin{array}{l}\text { Production, processing and } \\
\text { preservation of meat, fish, fruit, } \\
\text { vegetables, oils and fats }\end{array}$ & D1512 & $\begin{array}{l}\text { Processing and preserving of fish } \\
\text { and fish products }\end{array}$ \\
\hline & & D153 & $\begin{array}{l}\text { Grain mill products, starches and } \\
\text { starch products, and prepared } \\
\text { animal feeds }\end{array}$ & D1531 & Grain mill products \\
\hline & & & & D1533 & Prepared animal feeds \\
\hline D17 & Textiles & D171 & $\begin{array}{l}\text { Spinning, weaving and finishing of } \\
\text { textiles }\end{array}$ & D1711 & $\begin{array}{l}\text { Preparation and spinning of textile } \\
\text { fibres; weaving of textiles }\end{array}$ \\
\hline D18 & $\begin{array}{l}\text { Wearing apparel; dressing and } \\
\text { dyeing of fur }\end{array}$ & D181 & Wearing apparel, except fur apparel & D1810 & Wearing apparel, except fur apparel \\
\hline D19 & $\begin{array}{l}\text { Tanning and dressing of leather; } \\
\text { manufacture of luggage, handbags, } \\
\text { saddlery, harness and footwear }\end{array}$ & D192 & Footwear & D1920 & Footwear \\
\hline D20 & $\begin{array}{l}\text { Wood and of products of wood and } \\
\text { cork, except furniture; articles of } \\
\text { straw and plaiting materials }\end{array}$ & D202 & $\begin{array}{l}\text { Products of wood, cork, straw and } \\
\text { plaiting materials }\end{array}$ & D2021 & $\begin{array}{l}\text { Veneer sheets; plywood, } \\
\text { laminboard, particle board, other } \\
\text { panels and boards }\end{array}$ \\
\hline D24 & Chemicals and chemical products & D241 & Basic chemicals & D2412 & Fertilizers and nitrogen compounds \\
\hline \multirow[t]{2}{*}{ D25 } & Rubber and plastics products & $\mathrm{D} 251$ & Rubber products & D2519 & Other rubber products \\
\hline & & $\mathrm{D} 252$ & Plastics products & $\mathrm{D} 2520$ & Plastics products \\
\hline \multirow[t]{3}{*}{ D26 } & Other non-metallic mineral products & D269 & $\begin{array}{l}\text { Non-metallic mineral products } \\
\text { n.e.c. }\end{array}$ & D2693 & $\begin{array}{l}\text { Structural non-refractory clay and } \\
\text { ceramic products }\end{array}$ \\
\hline & & & & D2694 & Cement, lime and plaster \\
\hline & & & & D2695 & $\begin{array}{l}\text { Articles of concrete, cement and } \\
\text { plaster }\end{array}$ \\
\hline \multirow[t]{2}{*}{$\mathrm{D} 27$} & Basic metals & $\mathrm{D} 271$ & Basic iron and steel & D2710 & Basic iron and steel \\
\hline & & $\mathrm{D} 273$ & Casting of metals & D2732 & Casting of non-ferrous metals \\
\hline
\end{tabular}


VSIC2 VSIC2 description

D28 Fabricated metal products, except machinery and equipment
VSIC3 VSIC3 description

D289 Other fabricated metal products; metal working service activities

\section{VSIC4 VSIC4 description}

D2891 Forging, pressing, stamping and roll-forming of metal; powder metallurgy

D2899 Other fabricated metal products n.e.c.

\begin{tabular}{llllll} 
D31 & Electrical machinery and apparatus & D319 & Other electrical equipment n.e.c. & D3190 & Other electrical equipment n.e.c. \\
n.e.c. & Other transport equipment & D359 & Transport equipment n.e.c. & D3591 & Motorcycles \\
\hline D35 & Furniture; manufacturing n.e.c. & D361 & Furniture & D3610 & Furniture \\
\hline D36 & D369 & Manufacturing n.e.c. & D3699 & Other manufacturing n.e.c.
\end{tabular}

\section{LAND}

\begin{tabular}{|c|c|c|c|c|c|}
\hline D15 & Food products and beverages & D151 & $\begin{array}{l}\text { Production, processing and } \\
\text { preservation of meat, fish, fruit, } \\
\text { vegetables, oils and fats }\end{array}$ & D1512 & $\begin{array}{l}\text { Processing and preserving of fish } \\
\text { and fish products }\end{array}$ \\
\hline D18 & $\begin{array}{l}\text { Wearing apparel; dressing and } \\
\text { dyeing of fur }\end{array}$ & D181 & Wearing apparel, except fur apparel & D1810 & Wearing apparel, except fur appare \\
\hline D19 & $\begin{array}{l}\text { Tanning and dressing of leather; } \\
\text { manufacture of luggage, handbags, } \\
\text { saddlery, harness and footwear }\end{array}$ & D192 & Footwear & D1920 & Footwear \\
\hline \multirow[t]{2}{*}{ D24 } & Chemicals and chemical products & D241 & Basic chemicals & D2411 & $\begin{array}{l}\text { Basic chemicals, except fertilizers } \\
\text { and nitrogen compounds }\end{array}$ \\
\hline & & & & D2412 & Fertilizers and nitrogen compounds \\
\hline D25 & Rubber and plastics products & D252 & Plastics products & D2520 & Plastics products \\
\hline \multirow[t]{2}{*}{ D27 } & Basic metals & $\mathrm{D} 271$ & Basic iron and steel & $\mathrm{D} 2710$ & Basic iron and steel \\
\hline & & D273 & Casting of metals & D2732 & Casting of non-ferrous metals \\
\hline \multirow[t]{2}{*}{ D28 } & $\begin{array}{l}\text { Fabricated metal products, except } \\
\text { machinery and equipment }\end{array}$ & D289 & $\begin{array}{l}\text { Other fabricated metal products; } \\
\text { metal working service activities }\end{array}$ & D2891 & $\begin{array}{l}\text { Forging, pressing, stamping and } \\
\text { roll-forming of metal; powder } \\
\text { metallurgy }\end{array}$ \\
\hline & & & & D2899 & $\begin{array}{l}\text { Other fabricated metal products } \\
\text { n.e.c. }\end{array}$ \\
\hline D36 & Furniture; manufacturing n.e.c. & D369 & Manufacturing n.e.c. & D3699 & Other manufacturing n.e.c. \\
\hline
\end{tabular}




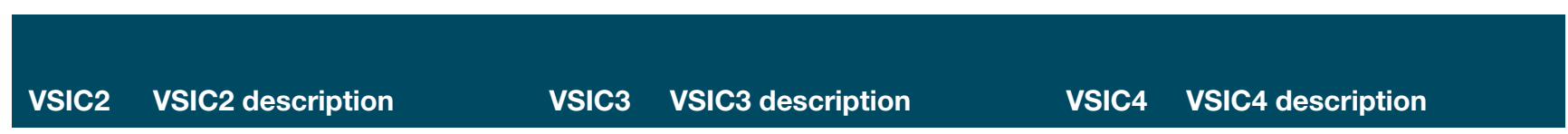

\section{WATER}

\begin{tabular}{|c|c|c|c|c|c|}
\hline D15 & Food products and beverages & D151 & $\begin{array}{l}\text { Production, processing and } \\
\text { preservation of meat, fish, fruit, } \\
\text { vegetables, oils and fats }\end{array}$ & D1512 & $\begin{array}{l}\text { Processing and preserving of fish } \\
\text { and fish products }\end{array}$ \\
\hline & & D152 & Dairy products & D1520 & Dairy products \\
\hline D20 & $\begin{array}{l}\text { Wood and of products of wood and } \\
\text { cork, except furniture; articles of } \\
\text { straw and plaiting materials }\end{array}$ & D202 & $\begin{array}{l}\text { Products of wood, cork, straw and } \\
\text { plaiting materials }\end{array}$ & D2021 & $\begin{array}{l}\text { Veneer sheets; plywood, } \\
\text { laminboard, particle board, other } \\
\text { panels and boards }\end{array}$ \\
\hline \multirow[t]{2}{*}{$\mathrm{D} 21$} & Paper and paper products & D210 & Paper and paper products & D2101 & Pulp, paper and paperboard \\
\hline & & & & D2102 & $\begin{array}{l}\text { Corrugated paper and paperboard, } \\
\text { containers of paper and paperboard }\end{array}$ \\
\hline \multirow[t]{2}{*}{ D24 } & Chemicals and chemical products & D241 & Basic chemicals & D2411 & $\begin{array}{l}\text { Basic chemicals, except fertilizers } \\
\text { and nitrogen compounds }\end{array}$ \\
\hline & & & & D2412 & Fertilizers and nitrogen compounds \\
\hline $\mathrm{D} 25$ & Rubber and plastics products & D252 & Plastics products & $\mathrm{D} 2520$ & Plastics products \\
\hline \multirow[t]{2}{*}{ D27 } & Basic metals & D271 & Basic iron and steel & $\mathrm{D} 2710$ & Basic iron and steel \\
\hline & & D273 & Casting of metals & $\mathrm{D} 2731$ & Casting of iron and steel \\
\hline
\end{tabular}


Figure B.1. Vietnam: $\mathrm{SO}_{2}$ emissions by sector

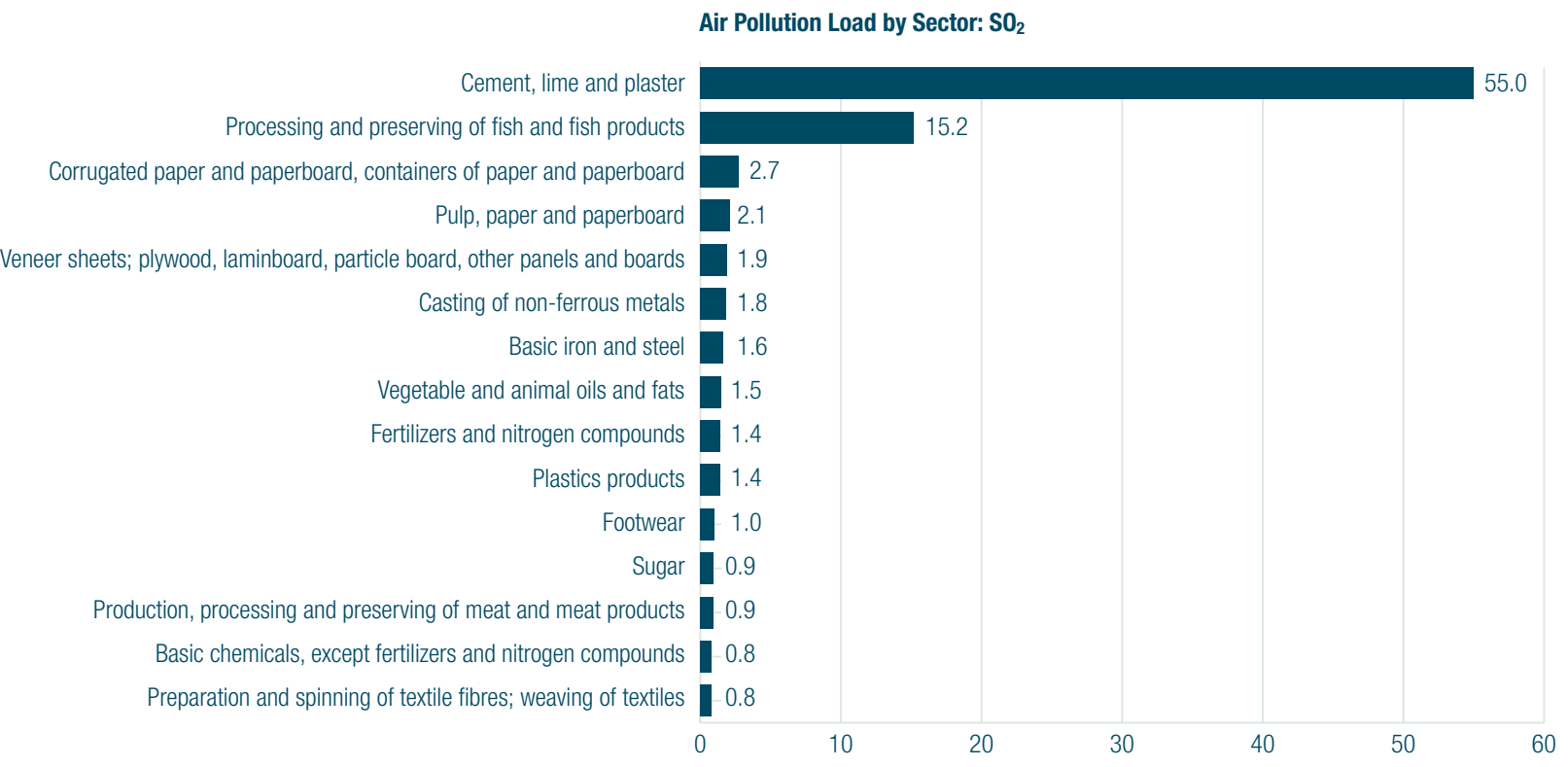

Source: ICEM estimates, 2006

Percentage contribution of each industrial sector to total national release

\section{Figure B.2. Vietnam: VOC emissions by sector}

Air Pollution Load by Sector: VOC

Processing and preserving of fish and fish products

Plastics products

Footwear

Furniture

Motorcycles

Fertilizers and nitrogen compounds

Other rubber products

Structural non-refractory clay and ceramic products

Distilling, rectifying and blending of spirits; ethyl alcohol production from fe

Other products of wood; cork, straw and plaiting materials

Basic chemicals, except fertilizers and nitrogen compounds

Corrugated paper and paperboard, containers of paper and paperboard

Vegetable and animal oils and fats

Pulp, paper and paperboard

Other manufacturing n.e.c.

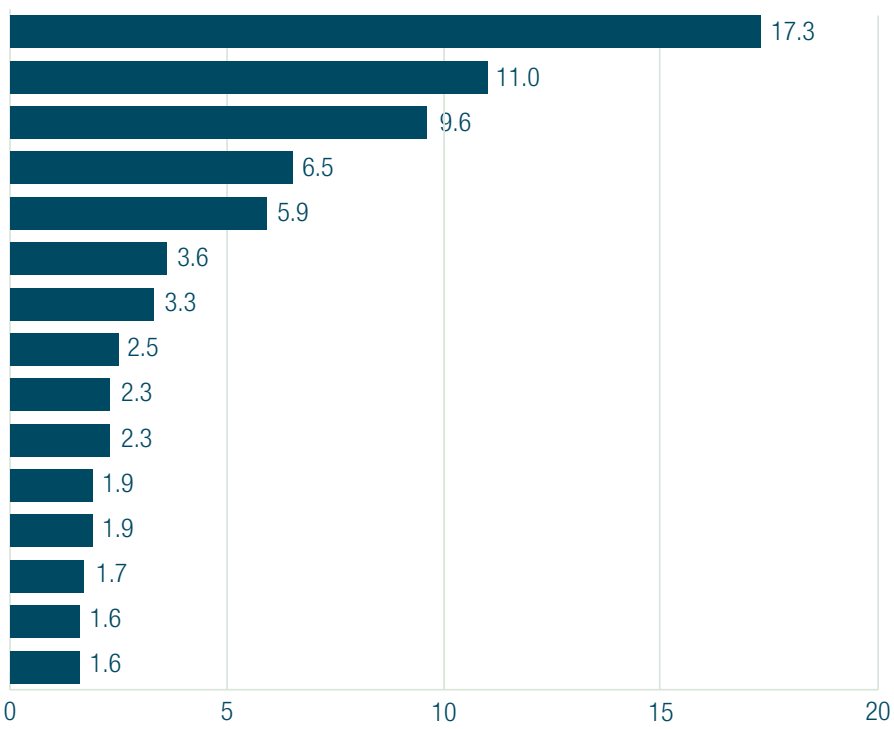

Source: ICEM estimates, 2006

Percentage contribution of each industrial sector to total national release 


\section{Figure B.3. Vietnam: TSP emissions by sector}

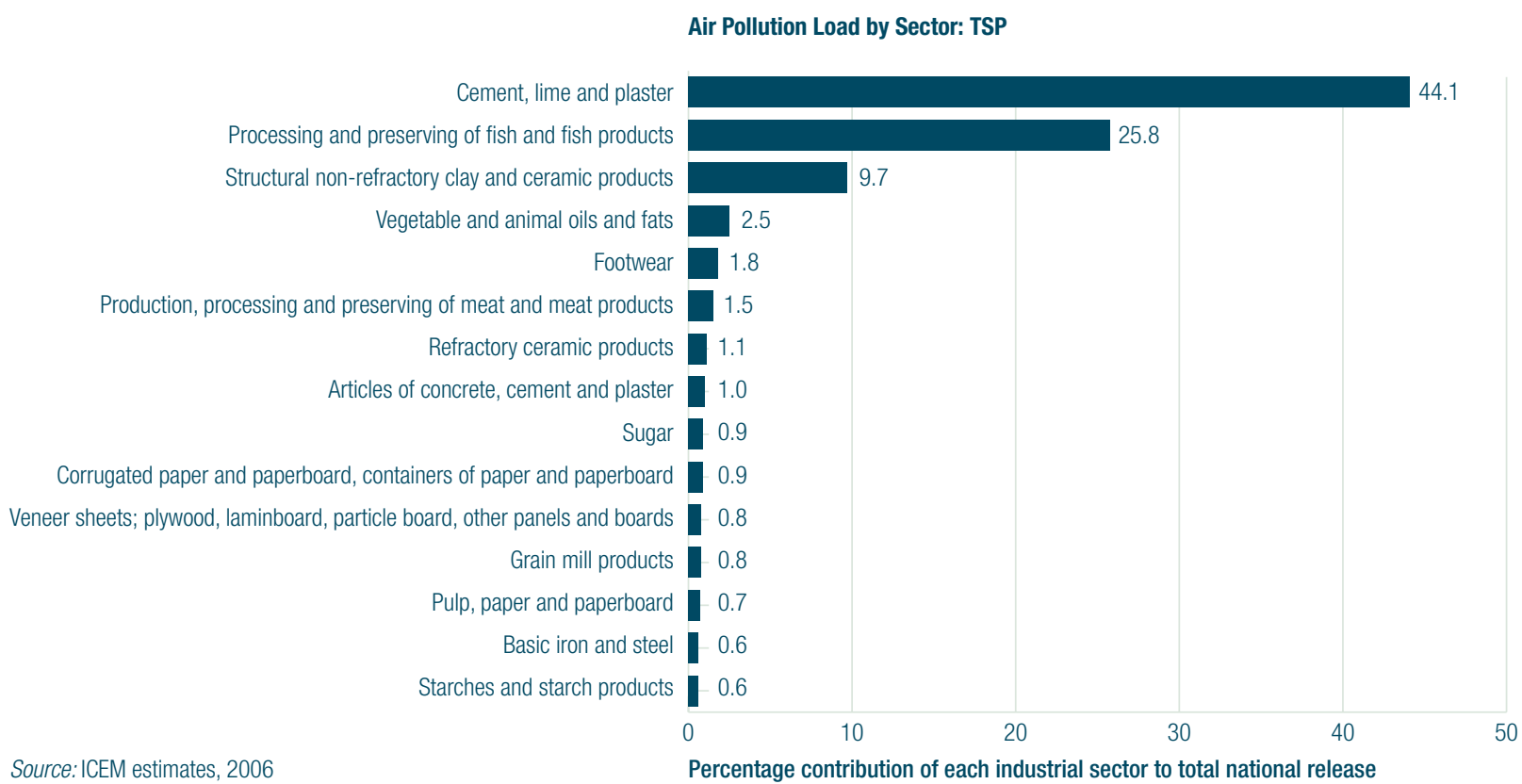

\section{Figure B.4. Vietnam: PM10 emissions by sector}

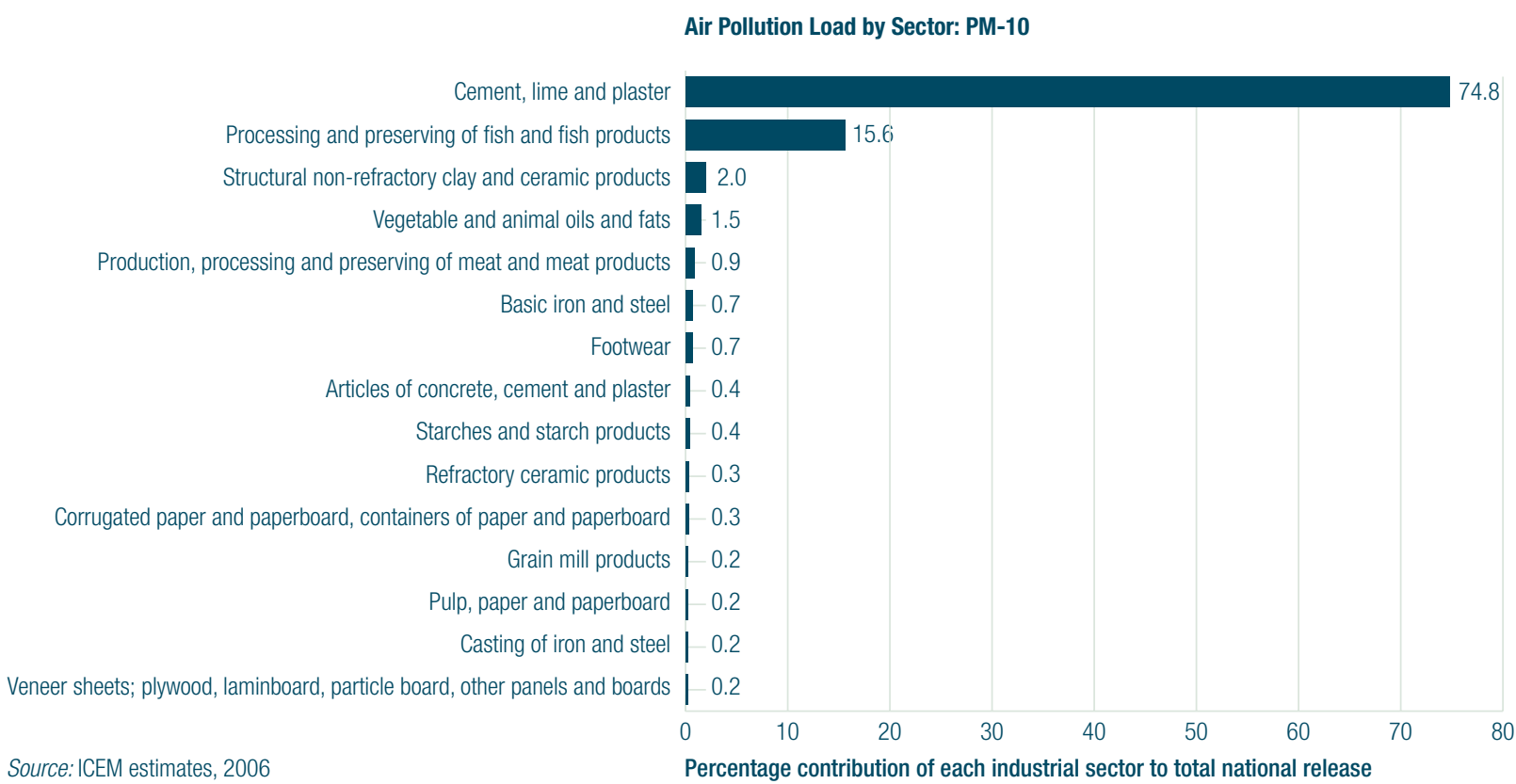




\section{Figure B.5. Vietnam: emissions of chemicals to air by sector}

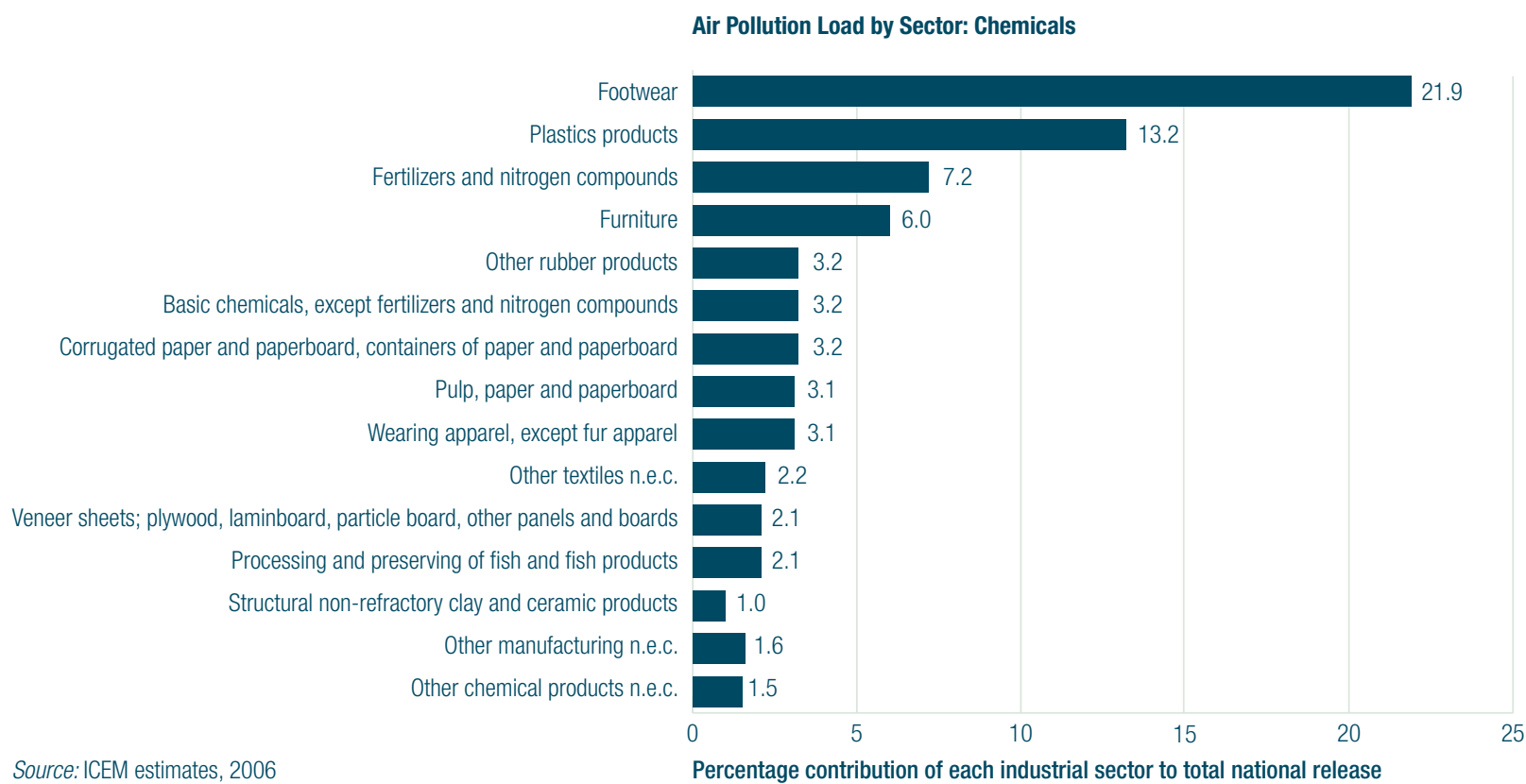

\section{Figure B.6. Vietnam: emissions of metals to air by sector}

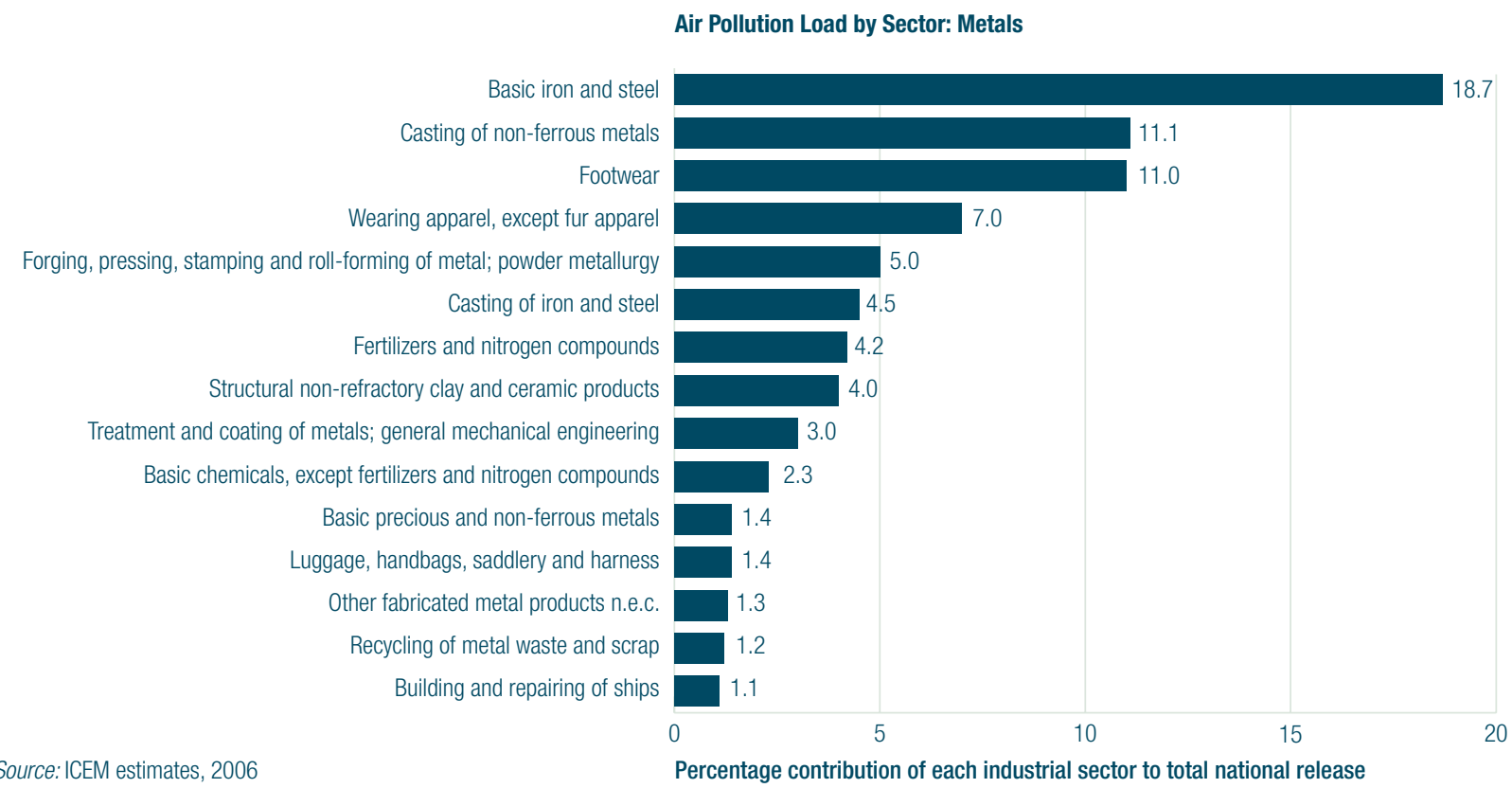




\section{Figure B.7. Vietnam: release of $\mathrm{BOD}_{5}$ by sector}

Water Pollution Load by Sector: BOD

Corrugated paper and paperboard, containers of paper and paperboard

Pulp, paper and paperboard

Veneer sheets; plywood, laminboard, particle board, other panels and boards

Dairy products

Processing and preserving of fish and fish products

Footwear

Fertilizers and nitrogen compounds

Sugar

Basic chemicals, except fertilizers and nitrogen compounds

Distilling, rectifying and blending of spirits; ethyl alcohol production from fe

Other non-metallic mineral products n.e.c.

Casting of non-ferrous metals

Furniture

Plastics products

Other food products n.e.c.

Source: ICEM estimates, 2006

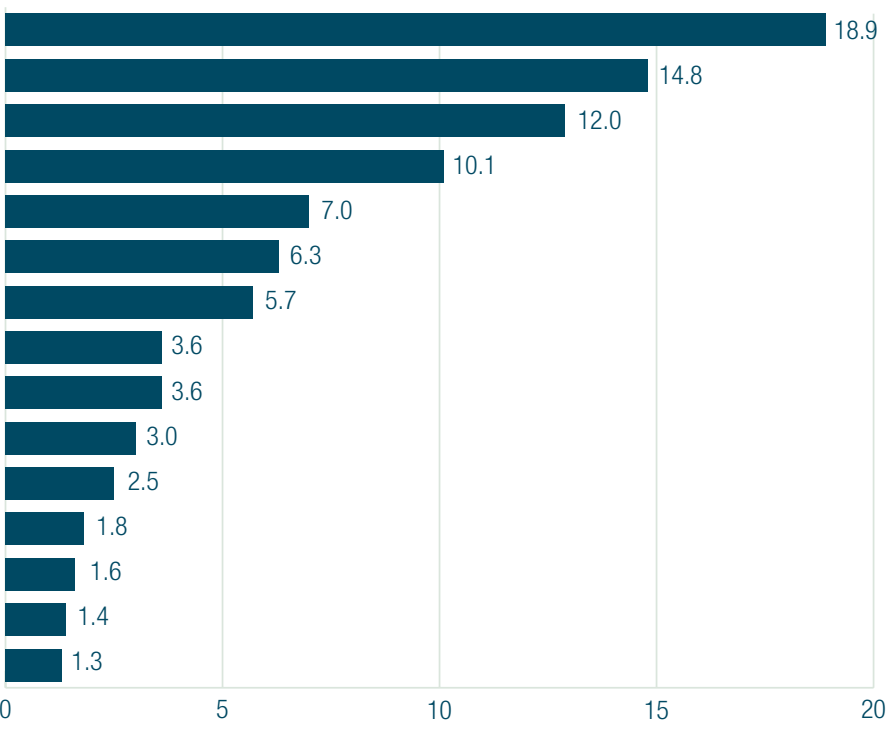

Percentage contribution of each industrial sector to total national release

\section{Figure B.8: Vietnam: release of TSS by sector}

Water Pollution Load by Sector: TSS

Basic iron and stee

Corrugated paper and paperboard, containers of paper and paperboard

Casting of iron and stee

Pulp, paper and paperboard

Veneer sheets; plywood, laminboard, particle board, other panels and boards

Forging, pressing, stamping and roll-forming of metal; powder metallurgy

Casting of non-ferrous metals

Fertilizers and nitrogen compounds

Pharmaceuticals, medicinal chemicals and botanical products

Treatment and coating of metals; general mechanical engineering

Footwear

Cement, lime and plaster

Railway and tramway locomotives and rolling stock

Jewellery and related articles

Processing and preserving of fish and fish products

Source: ICEM estimates, 2006

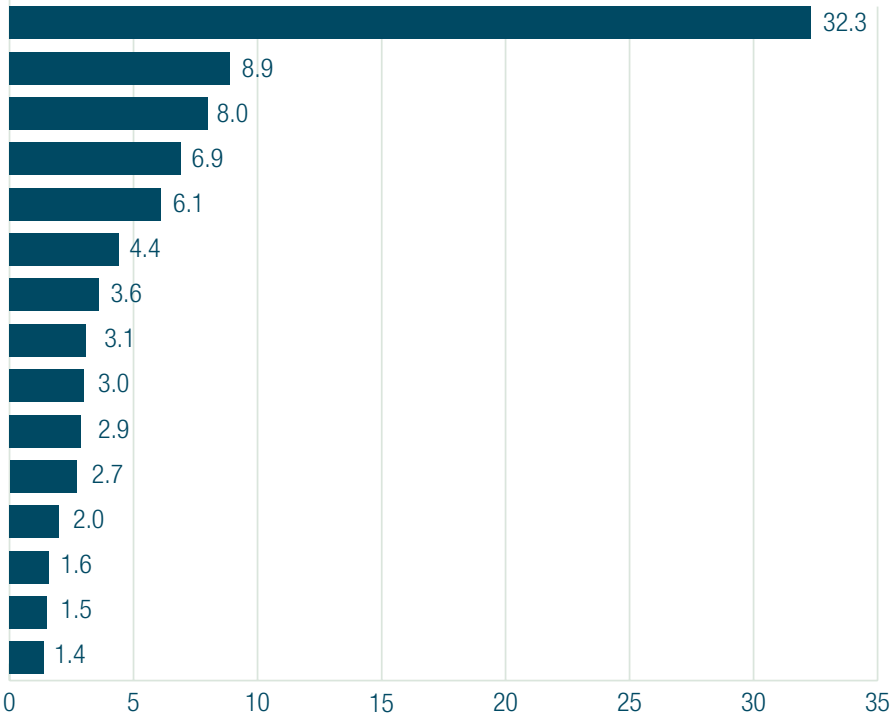

Percentage contribution of each industrial sector to total national release 
Figure B.9. Vietnam: release of chemicals to water by sector

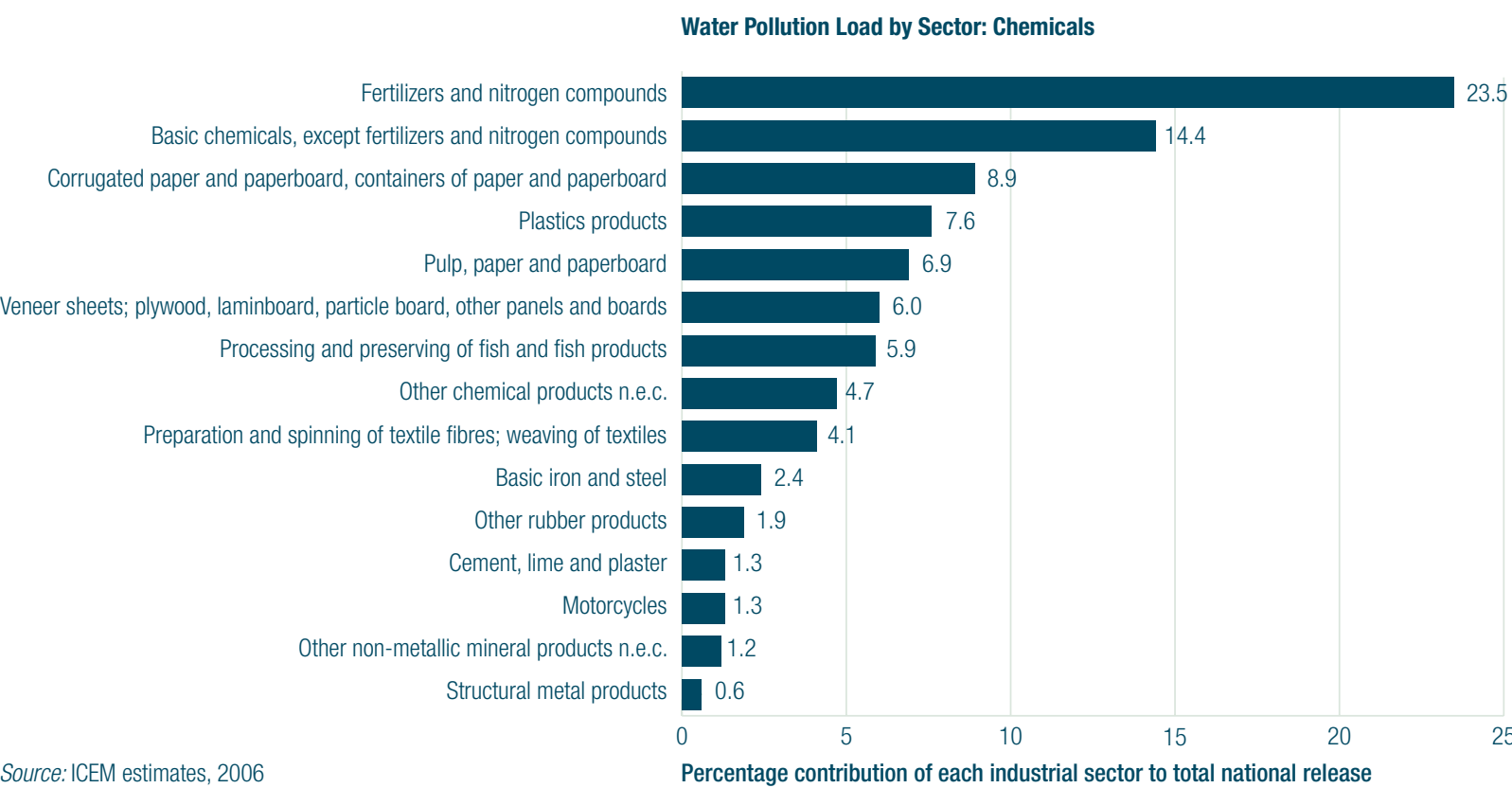

Figure B.10. Vietnam: release of metals to water by sector

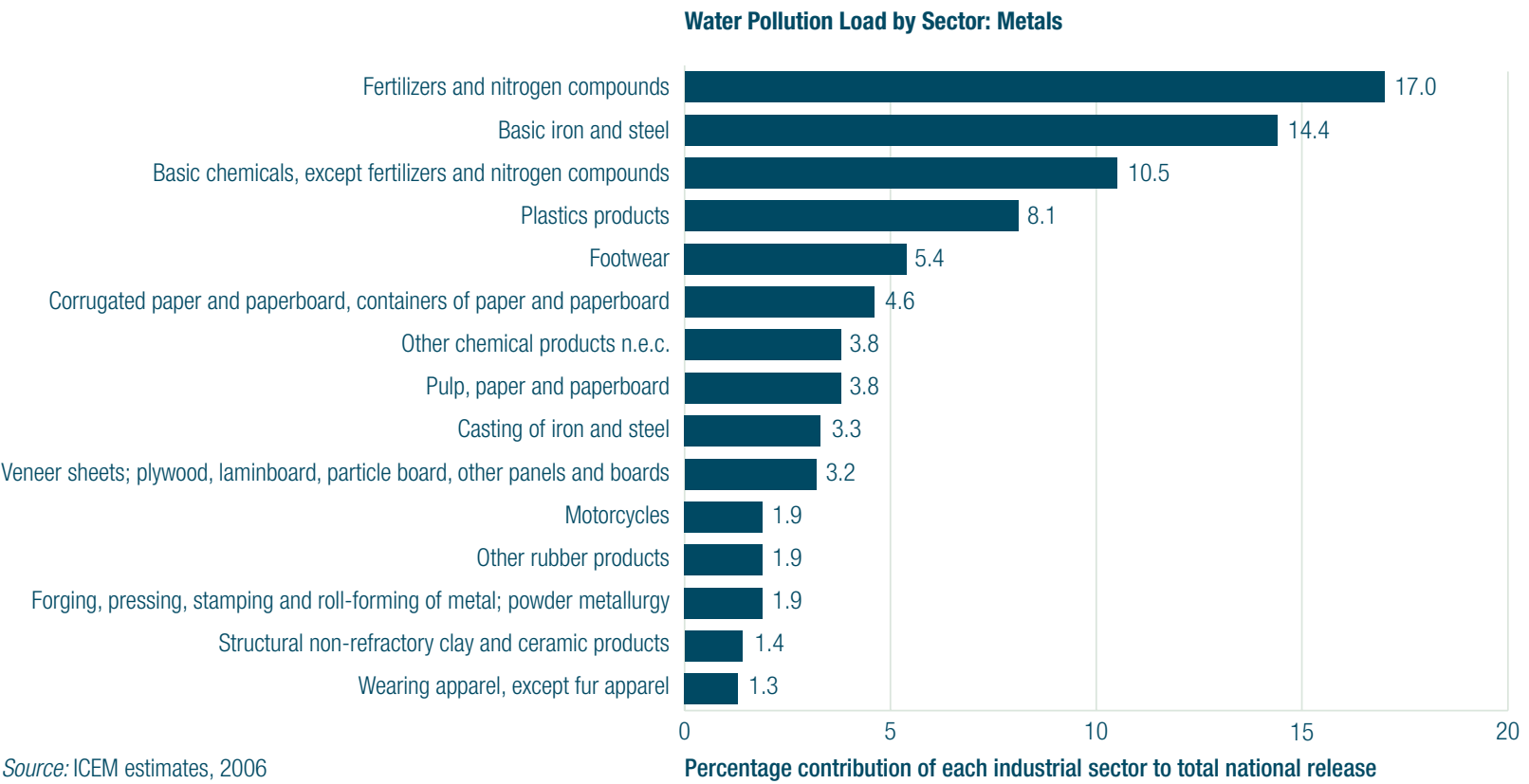

Source: ICEM estimates, 2006

Percentage contribution of each industrial sector to total national release 


\section{Figure B.11. Vietnam: release of chemicals to land by sector}

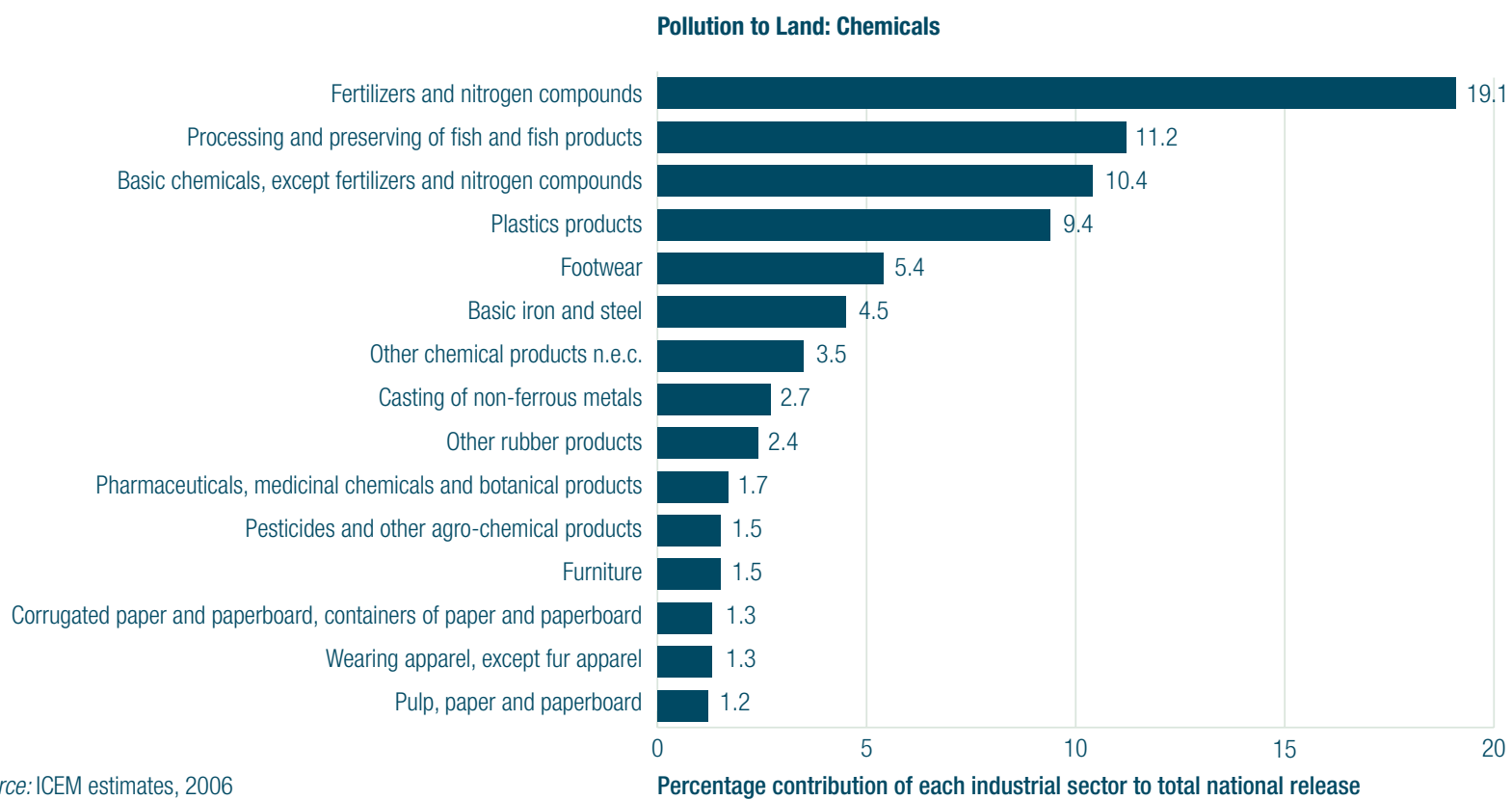

Source: ICEM estimates, 2006

Percentage contribution of each industrial sector to total national release

\section{Figure B.12. Vietnam: release of metals to land by sector}

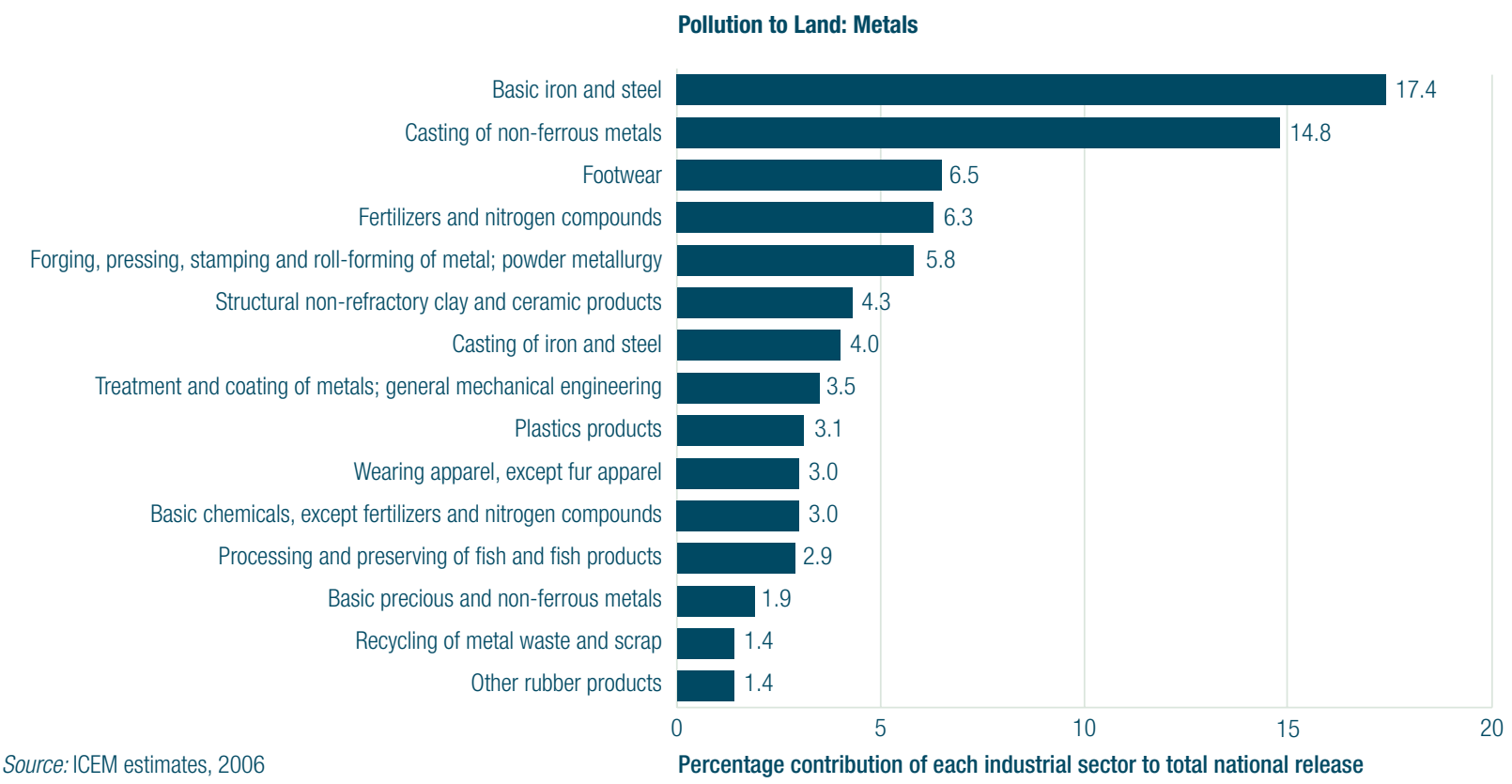

114 Rural Development, Natural Resources and Environment Unit of the East Asia and Pacific Region 


\section{ANMEX C. LEGAL INSTRUMENTS FOR INDUSTRIAL POLLUTION MANAGEMENT}

Policy or Legal Instrument: the Period of Accelerated Industrialization and Modernization dated 15 November 2004.

Government Decision No. 34/2005/QD-TTg of February 22, 2005, promulgating the Government's action program for implementation of the Politburo's Resolution No. 41/NQ-TW of November 15, 2004.

The Strategy for Socio-Economic Development 2001-2010, ratified by the Ninth Party Congress.

National Environmental Protection Strategy to 2010 and Orientation to 2020

Law on Environmental Protection, 2005
Resolution 41/NQ-TW of the Politburo on Environmental Protection in

\section{Overview and Guidance for IPM:}

The Resolution provides the overall vision for environmental management in Vietnam.

...maps out responsibilities and actions of the government and the people for implementation of Resolution \#41 above.

... acknowledges that rapid development, ensuring effectiveness and sustainable economic growth goes in parallel with realization of social equality, progress, and environmental protection

... presents the guiding view on , objective and activities of, and solutions to environment protection, and an Annex comprising of 36 priority programs for environmental protection...

... amends the Law on Environmental Protection of 1993 providing the framework for legal, institutional and administrative instruments for environmental protection.

... the overall objective of the Natural Resource and Environment 5-year Plan is "Natural resources and environment used and protect to ensure that economic growth, poverty reduction, and the quality of life are sustainable in accordance with the goals of the Government's" Five Year Plan 2006 2010"...

... The circular specifies the requirements, procedure and organization for the implementation of Agenda 21 for Vietnam.

09 March 2005 on "Implementation of the Strategic Orientation for Sustainable Development in Vietnam".

Joint Circular No. 01/TTLT-BTNMT-BNV. Ministry of Natural Resources and Environment and the Ministry of Home Affairs 15 July 2003.

... provides the guidelines for the setting up of functions, tasks, powers and organizational structure of the functional authority designated to assist the Provincial People's Committees in addressing natural resources and environment issues within the provincial level.

... specifies the functions, responsibility, authority and the Government Decree No. 91/2002/ND-CP of 11th November 2002 organizational structure of the Ministry of Natural Resources and Environment, superseding Decree 175 of 1994.

... establishes the provincial Departments of Natural Resources and Environment (DONRE) superseding Decree 175 of 1994.

... establishes roles and responsibilities for identification and reporting the worst pollution sources, and modes or implementation to address these sources.
Decision No. 64/2003/QD-TTg. Approving the plan for thoroughly handling establishments which cause serious environmental pollution. 


\section{Policy or Legal Instrument:}

Decree No. 67/2003/ND-CP. Environmental protection fee for waste water.

Decree No. 143/2004/ND-CP of July 12, 2004 Amending and Supplementing Article 14 of Decree 14 of Decree No. 175/CP of October 18, 1994

Circular No. 490/1998/TT-BKHCNMT OF April 29, 1998 Guiding the Making and Evaluation of Reports on the Assessment of Environmental Impacts of Investment Projects.

Decision 155/1999/QD-TTg on the Promulgation of Regulation on Hazardous Wastes Management.

Decree No. 121/2004/ND-DP of May12, 2004 on Sanctioning of Administrative Violations in the Field of Environmental Protection.

Decree No. 175-CP of 18th October 1994 Guiding the Implementation of the Law on Environmental Protection (1993)

TCVN 6980: 2001. Water Quality - Standards for industrial effluents discharged into rivers used for domestic water supply

\section{Overview and Guidance for IPM:}

... polluter pay fee system based on loading of selected pollution parameters..

... clarifies the division of responsibility for EIA review of MONRE and DONRE.

...guiding MOSTE Circular on EIA roles and responsibilities, review and approval in Vietnam.

... defines hazardous substances and establishes roles of and responsibilities for their management.

... prescribes violations of relevant regulations and applicable sanctions and remedial actions.

... establishes the responsibilities and functions of GOV and particularly MOSTE, the National Environment Agency, and the DOSTE under the Law on Environmental Protection.

... stipulates in detail limits values of parameters and concentrations of pollutants in industrial effluents by discharge volumes and flow rates of receiving rivers. 
THE WORLD BANK

1818 H Street, NW

Washington, DC 20433 USA

www.worldbank. org 